UNIVERSITY OF MONTANA

BULLETIN No. 30

BIOLOGICAL, SERIES NO, 10

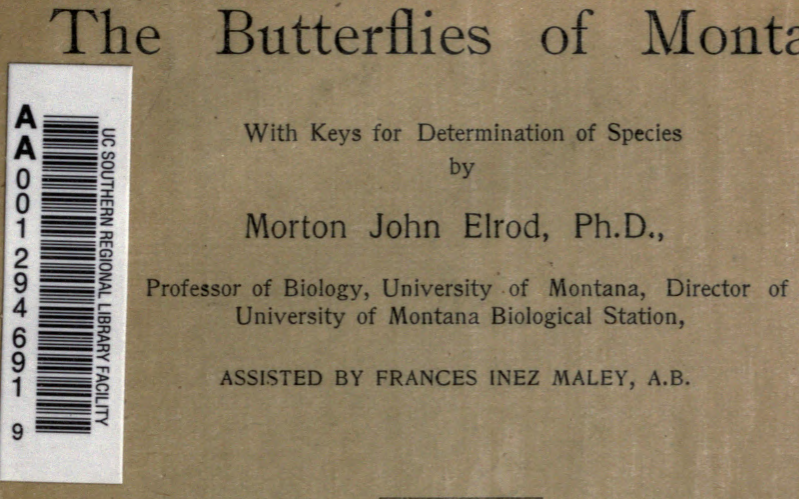

A Nature Study Bulletin, for the use of Teachers, Students and others who wish to study the Butterflies; with one colored plate, twelve plates in black and white, and one hundred and twenty-five figures.

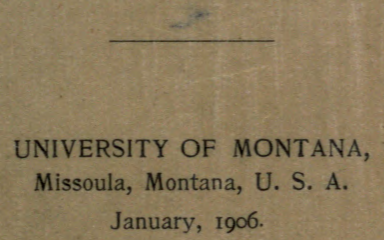

Entered August 24, 1901, at Missoula, Montana, as second class matter, under act of Congress July 16,1894 . 



\section{The Butterflies of Montana}

With Keys for Determination of Species

by

Morton John Elrod, Ph.D.,

11

Professor of Biology, University of Montana, Director of

University of Montana Biological Station,

ASSISTED BY FRANCES INEZ MALEY, A.B.

A Nature Study Bulletin, for the use of Teachers, Students and others who wish to study the Butterflies; with one colored plate, twelve plates in black and white, and one hundred and twenty-five figures.

\section{UNIVERSITY OF MONTANA, \\ Missoula, Montana, U. S. A. \\ January, I906.}

Entered August 24, 1901, at Missoula, Montana, as second class matter, unde ${ }^{r}$ act of Congress July 16, 1894 .

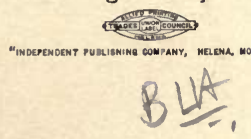


Copyrighted, 1906, by

The University of Montana. 
TO THE BOYS AND GIRLS OF MONTANA, WHO DELIGHT IN ROAMING THE HILLS OR IN FOLLOW. ING TH'E BANKS OF THE STREAMS. 



\section{EXPLANATION OF PLATE I.}

Fig. 1. Oeneas chryxus, Doubleday and Hewitson, showing lower surface.

Fig. 2. Upper surface of Lemonias chalcedon, Doubleday and Hewitson.

Fig. 3. Upper surface of Phyciodes mylitta, Edwards.

Fig. 4. Upper surface of male Chalceria rubidus, Edwards.

Fig. 6. Lower surface of Cercyonis sylvestris, var charon, Edwards.

Fig. 6. Lower surface of Thecla acadica, Edwards.

From water color drawings by Mrs. Edith Ricker.

All figures enlarged about one-third. 



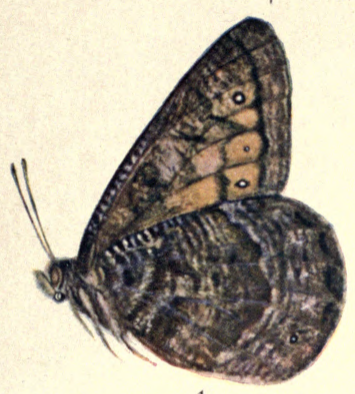

1.

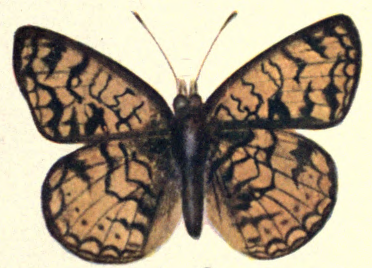

3.

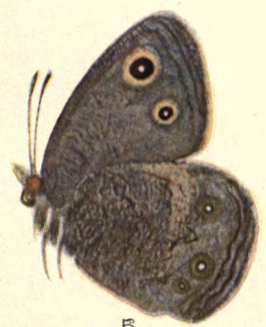

5.

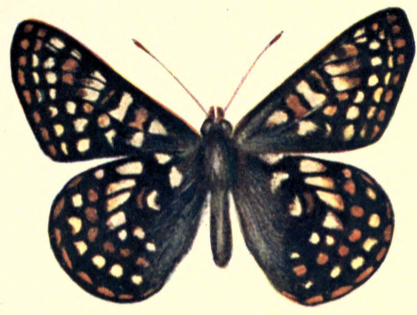

2.

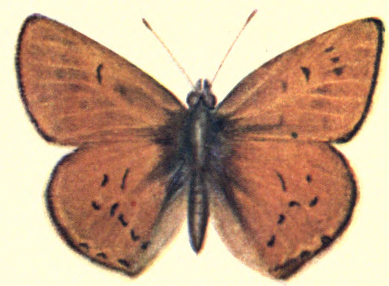

4.

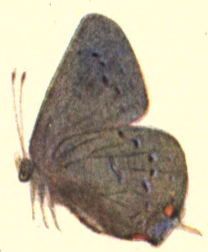

6. 



\section{Preface.}

In preparing some Nature Study work for teachers it became apparent that teachers have little to work on in this region to enable them to prepare studies on butterflies. It was really to assist teachers and others in identifying specimens that this bulletin was prepared. It is hoped that it will meet the needs of teachers and be of material assistance to them. The boys and girls of the state have little to assist them in the study of natural history specimens of the state, since the books which would be serviceable are either too expensice or too volumnious to handle. If the study of the butterflies is stimulated in the coming generation the writer will feel amply repaid.

Full credit for most of the assistance rendered has been given in the Introduction. Mrs. C. A. Wiley, of Miles City, has very kindly placed at our disposal a copy of Edwards' Butterflies of North America, with icolored plates. Supt. P. M. Silloway of, Lewistown, has rendered material aid in collecting specimens at Swan lake. The glossary has been prepared by Josiah J. Moore, of Anaconda, a student at the University of Montana. The index nas largely been prepared by my wife.

I offer no apology for making some of the descriptions much longer than others. Some of these are totally inaccessible to hundreds of those who will use this work. A lengthy description of a species that will be difficult of determination will be of great service to the young student. Where the specific characters are easy of determination and good photographs are supplied the descriptions are brief.

After the matter was all in type a list of butterflies was received from Prof. Ezra Allen, of the State Normal at Dillon, which specimens have been incorporated in the work. The information in this bulletin includes reference to specimens collected in the eastern end of the state at Miles City, the central portion at Bozeman, the southern part at Aldridge and Dillon, the main Rocky Mountain region at Helena, the western slope at Missoula and Flathead Lake.

Nov. 1, 1905.

M. J. E. 


\section{CONTENTS}

Key for the Determination of Butterflies $\ldots \ldots \ldots \ldots \ldots \ldots \ldots \ldots . . . \ldots \ldots$

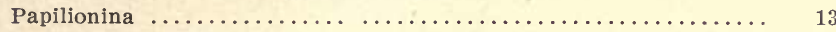

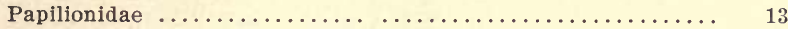

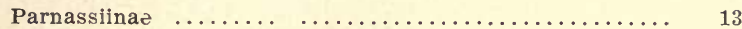

Papilioninae ............................... 19

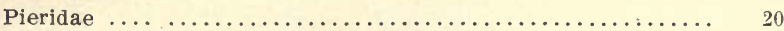

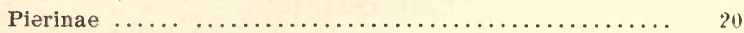

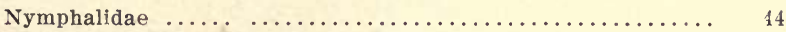

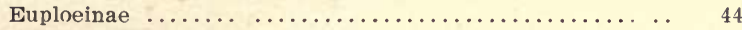

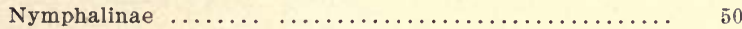

Agapetinae .................................. 105

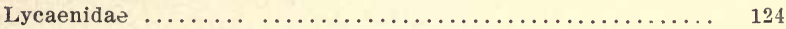

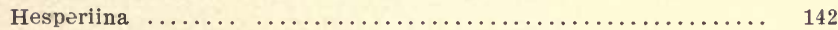

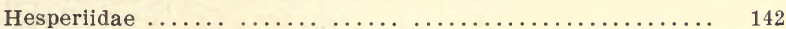

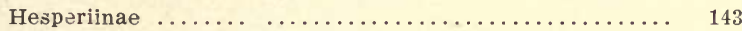

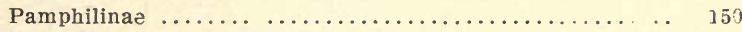

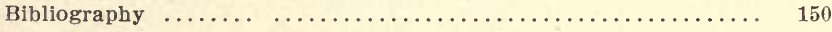

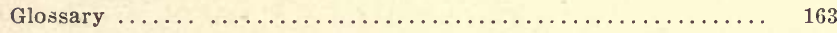

SUPPEMENTARY ARTICLES.

The Butterfly, Alice Freeman Palmer ................... 1

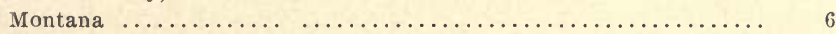

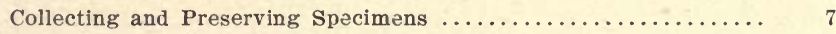

Collecting Butterflies at High Altitudes, M. J. Elrod............ 17

Butterflies and Fairies, Nellie A. Whitney ............... 36

Collecting butterflies at High Altitudes in the Andes, Whymper.... 43

The Seasonal Migration of Anosia plexippus, Maurice Ricker ..... 47

Butterflies at Miles City, Montana, C. A. Wiley .............. 66

A Chrysalis, poem, Mary Emily Bradley .................. 83

Eugonia J-album in Western Montana, Morton J. Elrod.......... 93

Mountain Swarming of Vanessa Californica, Hopkins ........... 94

Stridulation in Euvanessa antiopa, A. H. Swinton............ 97

Butterflies on Chimborazo, Humboldt .................. 104

Collecting Butterflies in Montana, Morton J. Elrod ............ 108

List of Butterflies taken by H. R. Morrison in Dakota and Montana,

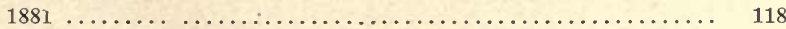

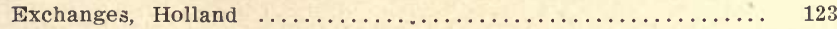

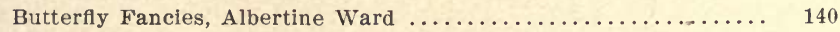

List of Species of Butterflies collected by Campbell Carrington and

William B. Logan, of the Expedition, in 1871, by W. H. Edwards 


\section{List of Plates.}

Plate I. Colored, frontispiece, showing Oeneas chryxus, Lemonias chalcedon, Phyciodes mylitta, Chalceria rubidus, Cercyonis sylvestris, and Thecla acadica.

Plate II. Map of Montana, showing places where collections have been made.

Plate III. MacDougal Peak in the Swan Range, a place where alpine forms of life have been taken.

Plate IV. The Clouded Sulphurs, genus Eurymus, showing different varieties.

Plate V. Genus Melitaea, showing different species.

Plate VI. Genus Basilarchia, the Admirals.

Plate VII. Among the Butterflies at the University of Montana.

Plate VIII. Daphnia Pond, near the Blological Station.

Plate IX. Upper end of Flathead Lake.

Plate $\mathrm{X}$. Oeneas chryxus.

Plate XI. The Blues, showing different species.

Plate XII. Pholisora catullus and Thanaos persius.

Plate XIII. Flowers on MacDougal Peak at $65 \mathrm{c0}$ feet elevation. 


\section{List of Figures.}

Fig. 1. A butterfly net.

Fig. 2. Paper for cyanide bottle.

Fig. 3. Cyanide bottle.

Fig. 4. Paper folded for insects.

Fig. 5. Setting board.

Fig. 6. Pinning forceps.

Fig. 7. Venation of Papilionidae.

Fig. 8. venation of Hesperiidae.

Fig. 9. Venation of Lycaenidae.

Fig. 10. Venation of Pieridae.

Fig. 11. Venation of Nymphalidae, Argynnis leto.

Fig. 12. Venation of Parnassius.

Fig. 13. Panassius smintheus, var. hermodour, male.

Fig. 14. Parnassius smintheus, var. hermodour, female.

Fig. 15. Parnassius clodius.

Fig. 16. Venation of Papilio.

Fig. 17. Papilio daunus.

Fig. 18. Papilio rutulus.

Fig. 19. Papilio eurymedon.

Fig. 20. Papllio brucei.

Fig. 21. Papilio zolicaon.

Fig. 22. Venation of Neophasia menapia.

Fig. 24. Neophasia menapia.

Fig. 24. Venation of Pontia.

Feb. 25. Pontıa protodice.

Feb. 26. Pontia rapae.

Fig. 27. Pontia napi.

Fig. 28. Pontia sisymbri.

Fig. 29. Venation of Synchloe.

Fig. 30. Synchloe ausonides.

Fig. 31. Synchloe sara.

Fig. 31. Synchloe olympia

Fig. 33. Venation of Eurymus.

Fig. 34. Eurymus philodice.

Fig. 35. Eurymus eurytheme, albino.

Fig. 36. Eurymus alexandra.

Fig. 37. Eurymus meadii.

Fig. 38. Venation of Nymphalidae.

Fig. 39. Anosia plexippus.

Fig. 40. Euptoieta claudia.

Fig. 41. Speyeria idalia.

Fig. 42. Argynnis cybele. 
Fig. 43. Venation of Argynnis leto.

F:g. 44. Argynnis leto, male.

Fig. 45. Argynnis leto, female.

Fig. 46. Argynnis aphrodite, var. alcest s, up 2 r suriace.

Fig. 47. Argynnis aphrodite, var. alcestis, lower surface.

Fig. 48. Argynnis edwardsii.

Fig. 49. Argynnis nevadensis, upper surface.

Fig. 50. Argynnis nevadensis, lower surface.

Fig. 51. Argynnis hesperis.

Fig. 52. Argynnis bremneri.

Fig. 53. Argynnis atlantis.

Fig. 54. Argynnis eurynome.

Fig. 55. Brenthis myrina, lower surface.

Fig. 56. Brenthis myrina, upper surface.

Fig. 57. Brenthis bellona.

Fig. 58. Brenthis helena.

Fig. 59. Lemonias taylori.

Fig. 60. Lemonias nubigena.

Fig. 61. Lemonias whitneyi, upper surface.

Fig. 62. Lemonias whitneyi, lower surface.

Fig. 63. Venation of Phyciodes.

Fig. 64. Phyciodes tharos.

Fig. 65. Phyciodes carlota.

Fig. 66. Phyciodes pratensis.

Fig. 67. Venation of Polygonia.

Fig. 68. Polygonia faunus.

Fig. 69. Polygonia taunus, satyrus and zephyrus.

Fig. 70. Polygonia zephyrus.

Fig. 71. Venation of Eugonia j-album.

Fig. 72. Eugonia j-album.

Fig. 73. Eugonia californica.

Fig. 74. wuvanessa antiopa, emerging from pupa.

Fig. 75. Euvanessa antiopa.

Fig. 76. Aglais milberti.

Fig. 77. Venation of Vanessa.

Fig. 78. Vanessa atalanta.

Fig. 79. Vanessa cardui.

Fig. 80. Vanessa caryae.

Fig. 80a. Vanessa huntera.

Fig. 81. Basilarchia archippus.

Fig. 82. Venation of Cercyonis.

Fig. 83. Cercyonis olympus, upper surface.

Fig. 84. Cercyonis sylvestris, var. charon.

Fig. 85. Where Leto abounds.

Fig. 86. Venation of Erebia epipsodea.

Fig. 87. Erebla epipsodea upper surface.

Fig. 88. Erebia epipsodea, lower surface.

Fig. 89. Venetian of Coenonympha.

Fig. 90. Coenonympha ochracea, upper surface. 
Fig. 91. Loenonympha ochracea, lower surfaç.

Fig. 92. Cocnonympha haydeni.

Fig. 92a. Oeneas uhleri.

Fig. 92b. Neominois ridingsii.

Fig. 93. Venation of Lycaena melissa.

Fig. 94. Uranotes melinus, Incisalia eryphon, Thecla saepium.

Fig. 95. Butterflies on the bank of Sinyaleamin lake.

Fig. 96. Venation or thecla.

Fig. 97. Inciscalia irus.

Fig. 98. Gaeides editha.

Fig. 99. Venation of Epidemia.

Fig. 100. Epidemia helloides.

Fig. 101. Chalceria snowi.

Fig. 102. Venation of Hesperiidae.

Fib. 102a. Cyaniris ladon.

Fig. 102b. Everes amyntula and Agriades rustica.

Fig. 103. Epargyreus tityrus.

Fig. 103b. Cocceius pylades.

Fig. 104. Venation of w celothrix.

Fig. 105. Scelothrix centaurea.

Fig. 106. Scelothrix scriptura.

Fig. 106a. Pyrgus montivaga.

Fig. 107. Pholisora catullus, slightly enlarged.

Fig. 108. Thanaos persìus.

Fig. 109. Thanaos persius.

Fig. 110. Thanaos afranius.

Fig. 111. Pamphila palaemon.

Fig. 111a. Oarisma powesheik.

Fig. 112. Venation of Erynnis.

Fig. 113. Erynnis uncas.

Fig. 114. Erynnis uncas.

Fig. 116. Ochloedes sassacus, upper and lower surfaces of male.

Fig. 117. जld cabin at Swan lake. 


\section{The Butterfly.}

I hold you at last in my hand, Exquisite child of the air; Can I ever understand

How you grew to be so fair?

You came to this linden tree To taste its delicious sweet,

I sitting here in the shadow and shine Playing around its feet.

Now I hold you fast in my hand, You marvelous butterfly Till you help me to understand The eternal mystery.

From that creeping thing in the dust To this shining bliss in the blue! God, give me courage to trust I can break my chrysalis too! 



\section{Introduction.}

The present bulletin is the result of eight years of collecting and tahulating material. My first butterflies captured in the state were taken at Miles City in the east and Mount Lo Lo in the west during a recreation trip in August, 1892. In 1897 I came to the state to live. Every summer since then to the present time has been spent in the field, and the accumulated insects have been arranged at the University of Montana, where they have been worked over at leisure moments.

In the fall of 1900 Miss Frances Inez Maley was given the task of spreading, arranging and labeling the material, identifying it so far as possible with the specimens and literature at command. A large portion of her time for that school year was devoted to the work. The collection of more than a thousand specimens was spread and arranged in Comstock cases. A large number of the photographs were taken at that time, others later. Many of the keys and descriptions were prepared by her, and the results of her careful and painstaking labor were submitted to the faculty as her graduating thesis for the degree B. A. in June, 1901.

As It was impossible then to correct and verify as must necessarily be done before printing, it was decided to test the keys and make further addition to the list by including references to all the collections available in the state. For several summers the keys have been in the hands of many persons both at the University in regular work and at the University of Montana Biological Station at Flathead lake. In this way many errors have been avoided, and the keys have been found to be serviceable in the hands of beginners. Moreover, by the examniation of other collections many additions were made, necessitating changes in the keys and in the text. Many of the discriptions were rewritten.

To avoid confusion it was decided to follow the nomenclature used by Dyar and others in Bulletin 52, United States National Museum. In this bulletin many species recorded in other publications are reduced to synonyms or varieties of other species. After examining so many hundreds of specimens from various parts of the state, at different altitudes, I feel convinced that the list can be reduced still further without detriment, and without sacrificing. To cite a single illustration. The Wiley collection has specimens of Argynnis from Miles City, collected in 1893, and identified by Edwards as A. edwardsi. Epecimens from Miles City sent by myself to Edwards in 1892 were labeled A. nevadensis. When placed side by side they look exactly alike, and are undoubtedly of the same species.

Owing to the varying conditions as to heat and cold, moisture and sunshine, which prevail in the state, many species are subject to great variation. This makes identification oftentimes difficult, and we have 
often been greatly puzzled. As a result of these great variations, combined with the mistakes one is likely to make in undertaking a task like this so far from library centers and large collections, we feel that we have certainly made many errors, of which we are now not aware. We have at least brought together the material in the state and have brought it into some kind of order for students of butterflies later to make more perfect. The task has been all the more difficult because the state contains specimens from the Great Plains region, from the Pacific coast region, and from the Boreal fauna in the north.

The collections examined and recorded in this bulletin are the followIng: (1) The collection made by the writer, almost entirely in the museum of the University of Montana, made during the past eight seasons of collecting. These have been taken mostly in the western end of the state. The numbers of specimens in the collection has not been determined, but there are many thousand. (2) George E. Barnes, a graduate of the University, made a collection of several hundred in the vicinity of Aldridge, in the southern part of the state near the Park. These were generously donated by him to the University. (3) E. N. Brandegee, of Helena, made a collection of several hundred specimens in the vicinity of Helena in 1902. These he very kindly placed at the disposal of the writer for examination and study. (4) The late C. A. Wiley, of Miles City, made an extensive collection of Lepidoptera in eastern Montana during his several years of residence in Montana. This collection came to the University entire, and has been gone over carefully. (5) The collection at the Montana College of Agriculture and Mechanic Arts at Bozeman, the work of Professor R. A. Cooley, was very kindly placed at my disposal by Prof. Cooley. This contains a good series of insects, excellently mounted, and in some cases from high altitudes. Eugene Coubeaux, of Big Sandy, made a collection during the summers of 1904 and 1 ' 05 , and very kindly loaned specimens for examination. He also furtnisiled notes regarding the abundance of each species. These five collections practically represent the butterfly collections in the state. They contain specimens from the extreme east and west, and from the south. The great section of country tributary to the Missouri river in the northeast is not represented, nor is the extreme north in the Rocky Mountains. Other authors have been referred to and quoted freely.

The illustrations are almost entirely original. The colored plate is the result of the work of Mrs. Edith Ricker, of Burlington, Iowa, who has spent three summers at the Station at Flathead. Colored drawings were made from specimens and the colored drawings were made into the printed plate by the three color process. It is to be regretted that the expense precluded more generous use of colored plates, instead of the half tones. Many of the drawings were also made by Mrs. Ricker and her brother, Lisle W. Brown, now in connection with the Eastman Kodak Company, including all of the figures of wing venation, except a few made by Claude Spaulding, laboratory assistant at the University. The photographs of butterflies were made by Miss Maley, Mr. Spaulding and the writer. Other photographs used have appropriate credit given with each. 
Without the generous aid of these friends, who gave their work cheerfully and gratuitously, these original illustrations would be lacking.

We are deeply indebted to President Craig, of the University, for the cordial support he has given us in our efforts to popularize this subject and make the study available to the younger generation of the state. His liberal policy has enabled us to use copious illustrations, and any plan for better results or for increased usefulness of publications has always met with his hearty favor.

The pleasure we have found in the preparation of the material for publication has been ample compensation for the labor. We can wish for those who peruse it or read it no more enjoyment in its use than has been ours in gathering the specimens and bringing them together. Every specimen which we have gathered recalls some scene, whether it be the jagged sky line of the back bone of the continent as viewed from the Swan range when we were sweeping in a few Phyciodes, a battered Eurymus alexandra, or the various species of Argynnids, or the quiet and peaceful woods adjacent to the laboratory at Flathead lake. Again, as we pick up Satyrus olympus or Brenthis myrina we are reminded of the dusky faces on the Flathead reservation and the beautiful Mission valley, flanked by the majestic Mission mountains. Vanessa californica brings to us in winter the first breath of spring, as it is our earliest specimen, coming at Missoula in 1903, February 19. Vanessa J. album carries us to Swan lake, where the manical call of the loon is answered by the blood curdling shrief of the puma, while the water lap-laps the bottom of our boat as we head for the campfire on shore.

Beautiful, dainty, golden laced Lycana melissa carries us to Sinyaleamin lake, cradled in the mountains, where we spent such happy and care free days. Oeneas chryxus takes our memory to Mount Woody, south of Missoula, which we have ascended a dozen times for butterflies. Whichever way we turn, whatever insect we pick up, our memory brings to us days of happiness and pleasure.

M. J. ELROD,

University of Montana. 


\section{Montana.}

Montana lies between the parallels of 49 degrees and 44 degrees 15 minutes north latitude, and extends from 104 degrees to 116 degrees west longitude. The form of the state is nearly a parallelogram, being about 540 miles in length with an average width of 275 miles.

The surface of the state is generally mountainous. The main range of the Rocky mountains, with numerous spurs, traverses the western part in a direction northwest to southeast; between these are many beautiful and extensive valleys, which cover nearly three-fourths of its area. The northeastern fourth is a high, rolling prairie country, covered with nutritious grasses. A considerable portion of the country between the Missouri and Yellowstone rivers is occupied by the Mauvaises Terres.

The average elevation of the surface is about 4,000 feet above the level of the sea. The elevation of the eastern third of the state is less than 3,000 feet, while that of the mountains and foothills in the western part of the state is from 4,000 to 10,000 feet. The highest peak is above 12,000 feet. The surface rises westward at the rate of about eight feet per mile.

This state has extremes of climate. Many sections of the state experience severe northern blizzards, others have delightful summers, still others hot deserts. Lovely lakes lie in the north, dry treeless plains in the east, almost devoid of vegetation. The western slopes with their copious rainfall afford a climate moist and warm. To the south are mountains capped with snow. Between these are many grand canyons. 


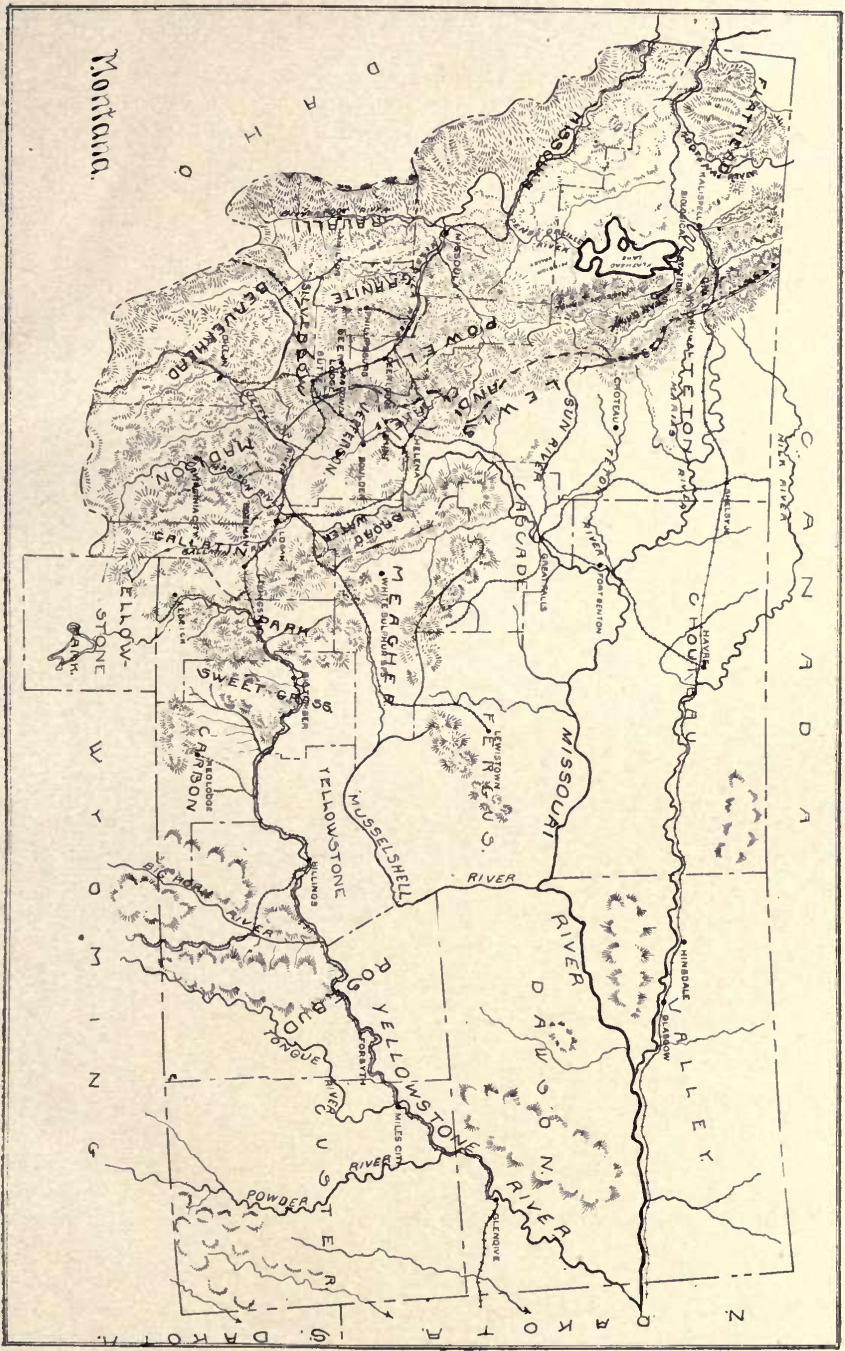

Map of Montana, showing geographical areas, and localities where collections have been made. 



\section{Collecting and Preserving Specimens.}

In collecting butterflies a net is necessary, and some means of killing them after capture.

The simplest form of the net, which can be made almost anywhere, is constructed as follows: A rod of some light stiff material is used as the handle, not more than five feet in length. Attached to this at its upper

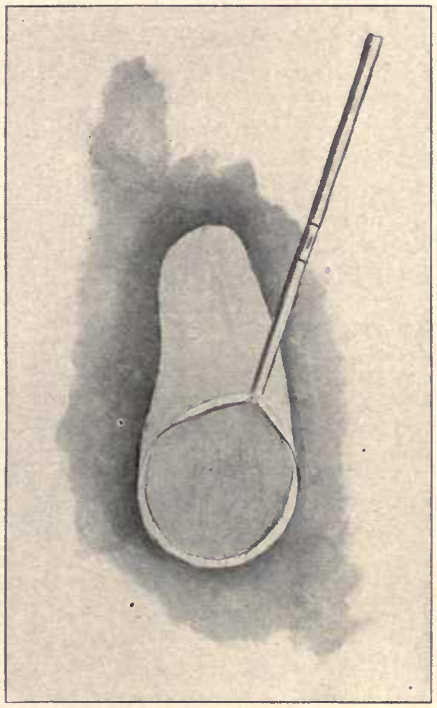

Fig. I. A butterfly net. end is a loop or ring made of metal or some moderately stiff yet flexible material. Upon this then should be sewed a bag of fine netting, preferably tarlatan, almost thirty inches deep; the ring should be not less than a foot in diameter.

Several formsof folding nets are on the market by dealers in entomological s u p plies. These nets are detachable from the handle, and will fold in two or more pieces. They may thus be tucked in a pocket or packed in with baggage without injury, to be drawn out and speedily ad. justed when necessary. Handles may also be purchased which fit together in sections, and are likewise easily transported and quickly adjusted. See Fig. 1.

Nets may be purchased with silk bags if desired. A silk bag has many advantages. It dries readily when wet, requiring but a few swishes through the air. It may be swept through the air with much greater speed than any other net. It does not snag readily, and has a much longer life.

The specimens collected are killed in some way that shall not mutilate them. A very convenient way is by means of the cyanide bottle, which is prepared in the following manner: Take a wide mouthed bottle holding four or six ounces. Put in the bottle a piece of cyanide of potassium about three-fourths of an inch square or a table spoonful of 
the pulverized, and water enough to cover the cyanide and then, imme-

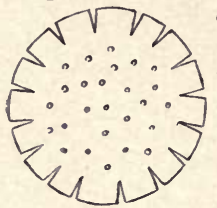
diately before there is time for the cyanide to dissolve, put enough plaster of Paris in the bottle to soak up the water. Cut a paper as in Fig. 2 to cover the plaster. The bottle should then be left open in a shady place for an hour to dry and then securely corked and labeled "Poison." See Fig. 3.

Specimens placed in the bottle to be killed should Fig. 2. Paper cut for be left there for at least a half hour, but they may be
cyanide bottle. left in over night without injury.

Another method of killing the insect is to enclose a piece of cotton, upon which a few drops of chloroform, sulphuric ether or benzene has been put, with the insect to be killed, in a small bottle or small box.

Still another method of killing is to entangle the insect in the meshes of the (silk) net, with wings over the back, and give a quick but hard squeeze on the sides of the thorax. This may do some injury to the insect by rubbing off some scales, but in the absence of a killing bottle it may be necessary to kill a specimen or lose it.

Much of the success of the collector will depend upon his skill in the use of his net. No description of the method is worth anything besides a very little experience, and one soon learns to capture with dextrous turn of the hand, "practice makes perfect." It is possible to sweep into the net an insect which is fluttering through the air and by a turn of the hand to close the bag. One manner which is preferred by many is to clap the net over the butterfly and allow it to rise, and then insert the bottle in the net and without touching it allow it to drop into the bottle. If possible the fingers should never be allowed to come in contact with the wings.

Papering Specimens-When time and place do not suffice for the proper preparation of the butterflies, they may be placed in envelopes, until such a time as one is able to relax and properly mount them. The small dry envelopes are very good for this. The insect while in the net usually has its wings folded back. It may also be dropped into a triangular envelope made by folding a

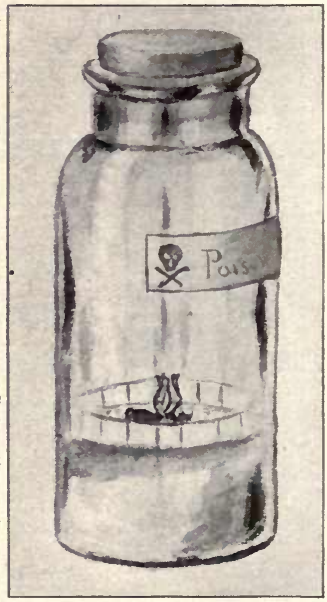

Fig. 3. Cyanide bottle. piece of paper as shown in Fig. 4, and a memorandum of the locality and date of capture is written on the envelope. They may then be packed in a shallow box, a cigar box being preferable.

When it is desired to pin and spread specimens that have been stored away they are relaxed. To do this take several large sheets of blotting paper, wet with water, place the papered butterflies on the sheets, then 
wet two more sheets and place over these. Do this as often as there are insects to be covered. Let them remain here two or threa days, at the end of which time they can be spread as easily as when fresh. Care must be taken not to leave the specimens here too long lest they became mouldy.

In spreading insects, the insect should first of all be pinned, the pin being thrust perpendicularly through the thorax, leaving about one-fourth of

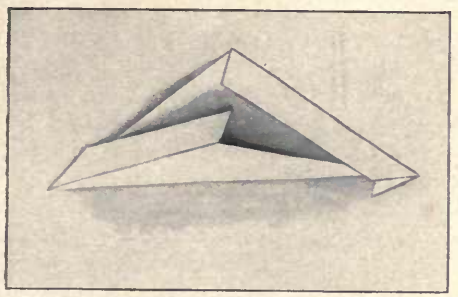

Fig. 4. Folded paper for insects. the pin to view. It should then be placed upon the setting-board. Setting-boards are two pieces of board slanted toward the inside. Many collectors prefer straight boards, with a piece of cork beneath, and a groove on the upper surface of sufficient depth to accommodate the body of the insect and to permit the wings to be brought to a level of the upper surface of the board. When the insect has been pinned upon the board the next step is to set the wings in the position which they are to maintain when the specimen is thoroughly dry.

In bringing the wings into position, care should be taken to put the pin behind the strong nervure, on the costal margin of the wing; otherwise the wings are liable to be torn and disfigured. The rule is to draw the anterior wing forward in such a manner that the posterior margin of this wing is at right angle to the axis of the body, the axis being a line drawn through the head to the extremity of the abdomen. The hind wing should then be moved forward, its anterior margin lying under the posterior margin of the fore wing. When thus arranged slips of paper should be drawn over them and securely pinned to keep them in position, and the pins removed from the wings. Never pin through the wing. Next the antennae should be adjusted, and placed parallel with the wings, and fine pins placed about them to hold them in position. Then if the body has a tendency to droop it should be raised by placing pins under it on either side. See Fig. 5 .

When insects have been spread the board should be placed where they will be unmolested and free from dust. They should be left here for about a week, longer if the insect is very large, at the end of which time they may be taken off and put in the cabinet.

Labelling-Each specimen should have on the pin below the specimen a small label, giving the date of capture, if known, and the locality. Labels should be printed, or written in a fine hand, and preferably with India ink. 


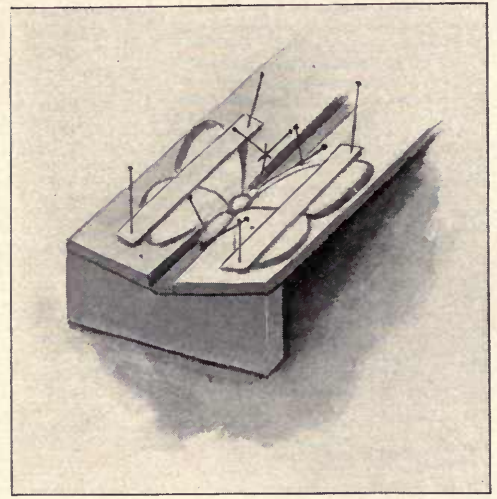

Fig. 5. Settling board, showing method of pinning and spreading Insects for the collection.

Pins-The insect pins are made longer and thinner than ordinary pins. Pins, pinning forceps, Fig. 6 , printed labels, insect boxes and cabinets, sheet cork or peat, or other entomological suppiles may be had of dealers in this material. A jappanned steel pin is now on the market which is much superior to any pins heretofore made in that smaller pins may be used and still have greater stiffness and strength. For cabinets such pins are much more desirable, but at the same time are more expensive than ordinary pins.

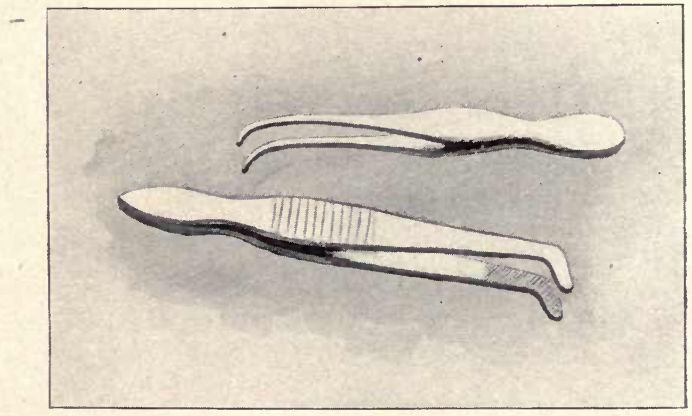

Fig. 6. Pinning forceps, for pressing pins into cork. 


\section{Venation of the Wings.}

The thickened lines in the wings are termed the veins or nerves; and their arrangement is described as the venation or neuration of the wings. The thin spaces of the wings which are bounded by the veins are called cells. When a cell is not completely surrounded by veins it is said to be open.

The wings of different insects vary greatly in structure, but they are all more are less triangular in outline; they therefore have three margins; the costal margin or costa (a b) ; the outer margin b, c, and the inner margin c. a. The angle at the base of the costal margin and the outer margin is the apex of the wing; and the angle between the outer margin and the inner margin is the anal angle.

The principal veins of the wings are, beginning with the one lying on the costal margin, the costa, the subcosta, the radius, the media, the cubitus, and the anal veins. The radius media, and cubitus are usually branched and there may be several anal veins.

In some insects there are the premedia a vein lying between the media and radia; and a postmedia lying between the media and the cubitus.

$\begin{array}{cl}\text { I } & \text { Costa } \\ \text { II } & \text { Subcosta } \\ \text { III } & \text { Radius } \\ \text { IV } & \text { Premedia }\end{array}$

IV Premedia

$\begin{array}{cl}\text { V } & \text { Media } \\ \text { VI } & \text { Postmedia } \\ \text { VII } & \text { Cubitus }\end{array}$

VI Postmedia
VII Cubitus

By referring to Figs. 7-12 these velns may easily be studled. As many of the generic distinctions are based on the venation it is essential that the student become thoroughly familiar with the locations and numbering of veins of wings.

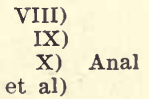

X) Anal 

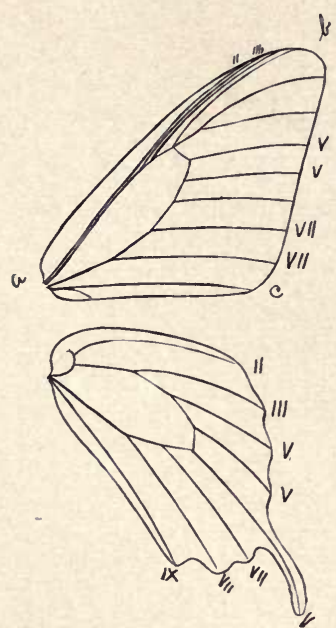

Fig. 7. Venation of wings, Papilionidae.

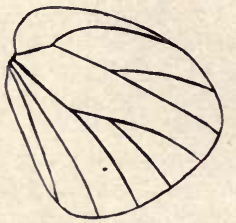

Fig. 8. Venation of wings, Hesperiina
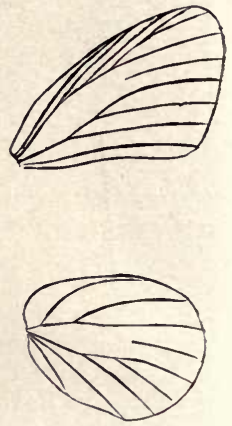

Fig. 9. Venation of wings, Lycaenidae.
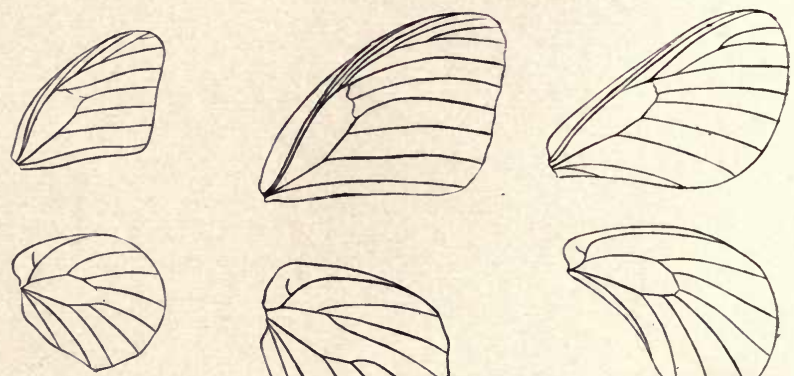

Fig. 10. Venation of wings, Pieridae.
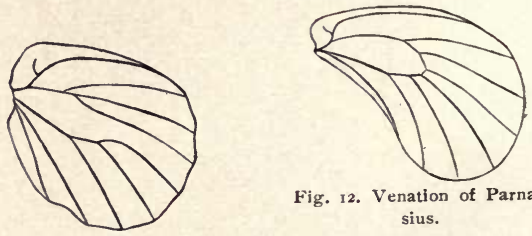

Fig. 12. Venation of Parnas sius.

Fig. 11 Venation of wings, Nymphalidae, Argynnis leto. 


\section{Key for Determation of Butterflies.}

1. Antennae thread-like with a knob at the extremity.-2.

2. With the radius of the fore-wings five-branched, Fig. 8 , and with all the branches arising from the discal cell; club of antennae usually terminated by a recurved hook. The Skippers. Hesperiina, page 142

3. With some of the branches of the radius of the fore-wwings coalesced beyond the apex of the discal cell, Fig. 7; club of antennae not terminated by a recurved hook. Butterflies. Papilionina, page13

\section{SUPERFAMILY PAPILIONINA.}

Key to Families.

1. Cubitus of the fore-wings apparently four-branched, Fig. 7.

Papilionidae. P. 13

Cubitus of the fore-wings apparently three-branched, Fig. 11.-2.

2. With six well developed legs, although in some species the fore legs of the male are a little shorter, and the tarsi of these lack one or both claws; radius of the fore wings, with rare exceptions, only three or four-branched. To determine the number of branches of radius, count the two cubital and the three medial branches first; the branches left between veins $\mathrm{V}$ and II belong to the radius.-3.

With only four well developed legs, the fore legs being unused, much shorter than the others, and folded on the breast like a tippet (except in the female of Hypatus). Radius of fore wings five-branched, Fig. 11.

Nymphalidae. P. 44

3. Vein $\mathrm{V}$ of the fore-wings arising at or near the apex of the discal cell, Fig. 9, except in Feniseca tarquinius, in which the wings are dark brown, with a large fulvous spot on each. Lycaenidae. P. 124 The first branch of media of the fore wings united with the last branch of the radius for a considerable distance beyond the apex of the discal cell. Fig. 10. Ground color of the wings white, yellow or orange.

Pieridae. P. 26

\section{FAMILY PAPILONIDAE.}

Key to the Subfamilies.

Hind wings with a tail like prolongation; ground color of wings black; radius of fore wings five-branched; the base of vein VIII of fore wings preserved as a spur like branch of vein VII, Fig. 7.

Papilioninae. P. 19

Hind wings without tail like prolongation; ground color of wings white; radius of fore wings four-branched; vein VIII of fore wings wanting, Fig. 12.

Parnassiinae. P. 13

\section{SUB-FAMILY PARNASSIINAE.}

The Parnassiinae differ from the Papilioninae in lacking the tail-like prolongation of the hind wings and in that the ground color of the wings 
is white, but resemble them in possessing similar scent organs in the larval state. They are found only on high mountains or far north.

\section{Key to Genera.}

Medium size, diaphanous wings, white or yellow in color, marked with black spots and round pink or yellow spots margined with black.

\section{Genus PARNASSIUS, Latrielle.}

Parnassius.

Butterfly-Medium size, with diaphanous wings, generally white or yellow in color marked with black spots, and round pink or yellow spots. The head is relatively small, thickly clothed with hairs. The antennae are short and straight. The wings have a rounded apex. The upper radial is lacking.

Early Stages-The egg is turban-shaped. The caterpillars have very small heads. They are flattened and dark brown or black in color with light spots.

\section{Key to Species.}

Males with very light wings, black reduced to a row of marginal and submarginal lunules, the latter often lacking. Females with the whole upper surface of primarus smoky black. Antennae with black and white rings, black knobs.

smintheus.

Males with darker wings, a sub-marginal row of white lunules. Females much like males, but darker. Antennae black . clodius

\section{THE PARNASSIUS BUTTERFLY.}

Parnassius Smintheus, Dbl. and Hew., var Hermodour. Fig. 13, Male; Fig. 14, Female.

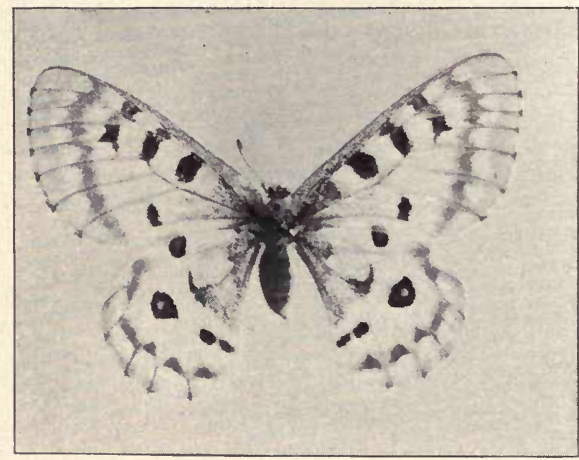

Fig. 13, Parnassius smintheus, var. hermodour, male.

Butterfly-This beautiful insect is subject to great variations. The expanse of the wings of the female is 2.25-3.00 in., male 2.00-2.50 in. The white ground is marked with smoky black to a greater or less extent. On the wings are yellow or pink spots, varying in size, margined 
with black. There is a marked difference between the females and males, the latter being much whiter with the smoky black confined to the outer border of the wings and the inner edge of the hind wings. There is a black bar in the middle of the discal cell of fore wings, another at the outer end of the cell, beyond which is a more or less prominent bar with or without red spots (one or two). The female is much darker, with the whole upper surface of the primaries usually smoky-black hue, slightly transparent, the usual bands being lost in the ground color of the wing. Yellow or pink spots much larger than in the male.

The variety hermodour is much blacker than smintheus. Both are found in the state. Comparison of specimens from Montana with those from Pike's Peak show the latter to be much smaller, and lighter. As

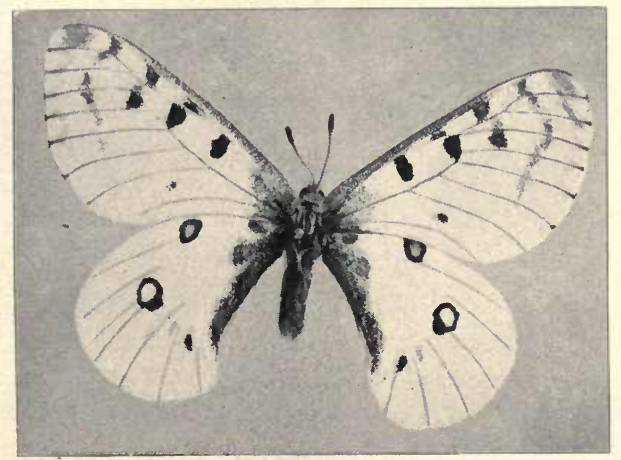

Fig. 14, Parnassius smintheus, var. hermodour, female.

the Pike's Peak specimens are from altitude 12,000 feet and Montana specimens from 3,000 to 7,000 this is to be expected.

These butterflies are truly Alpine, and fly for but a short season of the year. The lowest altitude at which they have been taken is about 3,000 feet near the Biological Station at Flathead lake. At Missoula they are rare, and have not been taken below 5,000 feet, and then in small numbers. They fly lazily but easily. Owing to the fact that they are usually taken at high altitudes their capture results in much fatigue. Often they sail gracefully over a cliff when the pursuer is all but ready for a sweep of the net. In the same locality high eleavtion seems to result in smaller and blacker specimens, low elevation in larger and whiter ones.

Distribution-The University collection contains specimnes from Missoula, Tobacco Root Mountains, Mission Mountains, New Chicago, Madison Lake, Geyser Basin, Flathead Lake, the Swan Range and the National Park. It is found at higher elevations throughout the state, ranging from Colorado to California, Montana to New Mexico. Its northern limit is unknown. According to Edwards it has been taken as far 
as Loggan, Alberta. Coubeaux has collected it at Sheep Creek near Big Sandy. He says it is not common in the Highwood and Little Belt Mountains, and that it seems to be absent from the Bear Paw Mountains.

Food-The caterpillar feeds on Sedum and Saxifraga. The butterfly is common in the mountains about Helena (Brandegee). Cooley has collected it at Bozeman.

THE CLODIUS BUTTERFLY.

Parnassius clodius Menetries, Fig. 15.

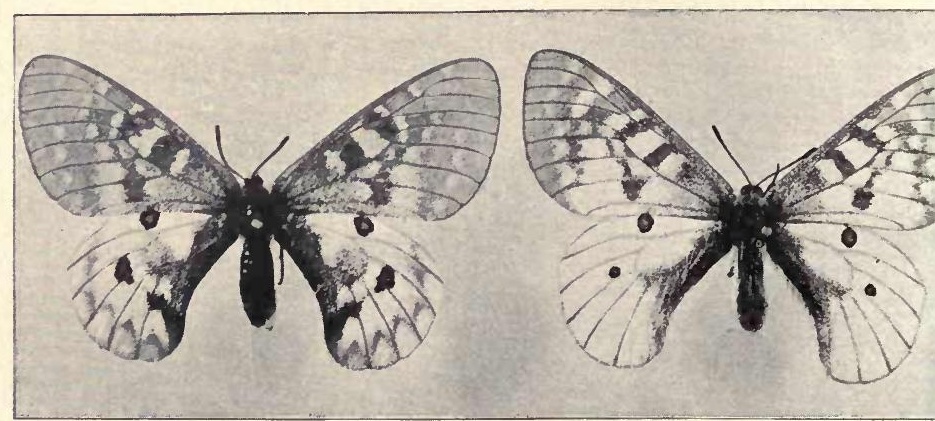

Fig. 15, Parnassius clodius.

Prof. R. A. Cooley, of the College of Agriculture and Mechanic Arts at Bozeman, has sent us two specimens, male and female, of this species, taken in Gallatin county, where he reports them rather abundant. The pink and yellow spots are lacking on the primaries in both sexes.

The male has more smoky brown on the outer edge and base of primaries, with more translucent outer margin. The differences are more clearly shown by comparison of Figs. 13 to 15 .

Distribution-Clodius is found upon the mountains of California. It is reported from the state by Prof. Cooley as stated. Carrington and Logan collected it on the expedition in 1871.

Food-The capterpillar feeds on Sedum and Saxifraga. 


\section{Collecting Butterflies at High Altitudes.}

My first high altitude collecting was at 11,500 feet at Seven Lakes, Pike's Peak. It was in August, 1892. Ice formed at night, and all insect life was quiet. During the warm days butterflies were abundant. For the first time I saw Parnassius in all its splendor. But to capture it was difficult. Not being accustomed to the high altitude I was unable to make vigorous effort, and after a short chase would drop to the ground gasping for breath. Our camp was in the valley on the bank of one of the "Seven Lakes," in the home of Parnassius smintheus. They were out by the thousands. A few miles from camp, toward the main summit, an irrigation or water ditch had the surface of the water covered as far as we could see in either direction with dead or struggling larvae of smintheus.

Above timber line and up to the line of perpetual snow there is in summer a profuse growth of Alpine flowers. One who has not seen high altitude vegetation cannot comprehend the beauty, splendor, and profusion of high altitude or alpine flowers. They are a sight never to be forgotten. Above timber line there is in summer a profuse growth. On sheltered or sunny slopes there is a varied vegetation, the flowers making a beautiful sight. One of these visions is the most gorgeous I have ever seen or ever hope to see.

I was caught in a shower of rain, hail, sleet, and snow, and had hastened to a large rock. By clinging with both hands and feet I was somewhat protected. After an hour the storm passed, and the sun came out bright and warm. Sunshine always brings out insects, if they are about. The storm left a deposit of snow an inch or two in depth over the surface of the mountain for miles around. Above the snow, showing their varied colors, were thousands of flowers of different tints, from the genera Actinella, Allium, Mertensia, Silene, Castilleia, Polygonum, Geum, Sedum, and Potentilla. Hovering over these flowers were hundreds of butterflies, displaying their gorgeous colors. It was a rare sight, and a rare combination of snow, alpine flowers and alpine butterflies. The insects were Parnassius smintheus, Colias ochraeus, Colias meadii, Argynnis eurynome, Phyciodes nycteis, Argynnis helena, and Lycaena rustica.

Such a blending and contrast of colors is rarely seen, and forgetting everything I stood for a long time drinking it in. This view is indelibly stamped on my memory. It cannot be forgotten. Soon the mournful squeak of the pika on the rocks nearby called my attention, as it was the pika I was after. In a short time the snow had disappeared, and the six mile walk to camp was cheerfully made.

It has not been my good fortune to climb high mountains. I have done no collecting above 14,000 feet. Among the Rockies of Montana my work has been at altitudes below 10,000 feet. My next attempt at 
collecting at altitudes higher than common was in the National Park, at an altitude of 8,500 feet. Again I saw Parnassius smintheus, that gorgeous insect of the alpine realm. I gave chase, and after landing the prize in the net sank to the ground exhausted and gasping for breath. In the Mission Mountains of Montana I have had many a happy day among the peaks at 9,500 feet and lower. This short range has some of the most beautiful mountain scenery in the world. Many of the insects taken are recorded in this work. I have collected in the Swan range, and in the main range of the Rockies, at altitudes up to 10,000 feet. In northern Montana timber line is 9,500 feet. In Colorado it is about 11,500 or 12,000 feet. These two elevations in the different localities will probably have about the same flora and fauna, or at least similar conditions. Never have I found insects so abundant as at Seven Lakes on Pike's Peak, and rarely are they abundant. Quite frequently but a single specimen is captured, often but a few. For several years we have annually made the ascent of MacDougal Peak in the Swan Range, whose elevation is approximately 7,600 feet. On these occasions I stay behind to see that all are going down safely. I always loiter on the summit or along the long ridge, collecting a few Lycaenas, Argynnids, Pierids, or Phyciodes.

If the butterfly students of Montana will seek healthful exercise, magnificent view of snow-clad mountain summits and peaceful wooded valleys, with a catch of few but rare and very choice insects, let them ascend some high peak in July or August, seek a sunny slope of open woods and abundant vegetation, and pitch their tents for a week. It will add years to the latter end of life.

M. J. E. 


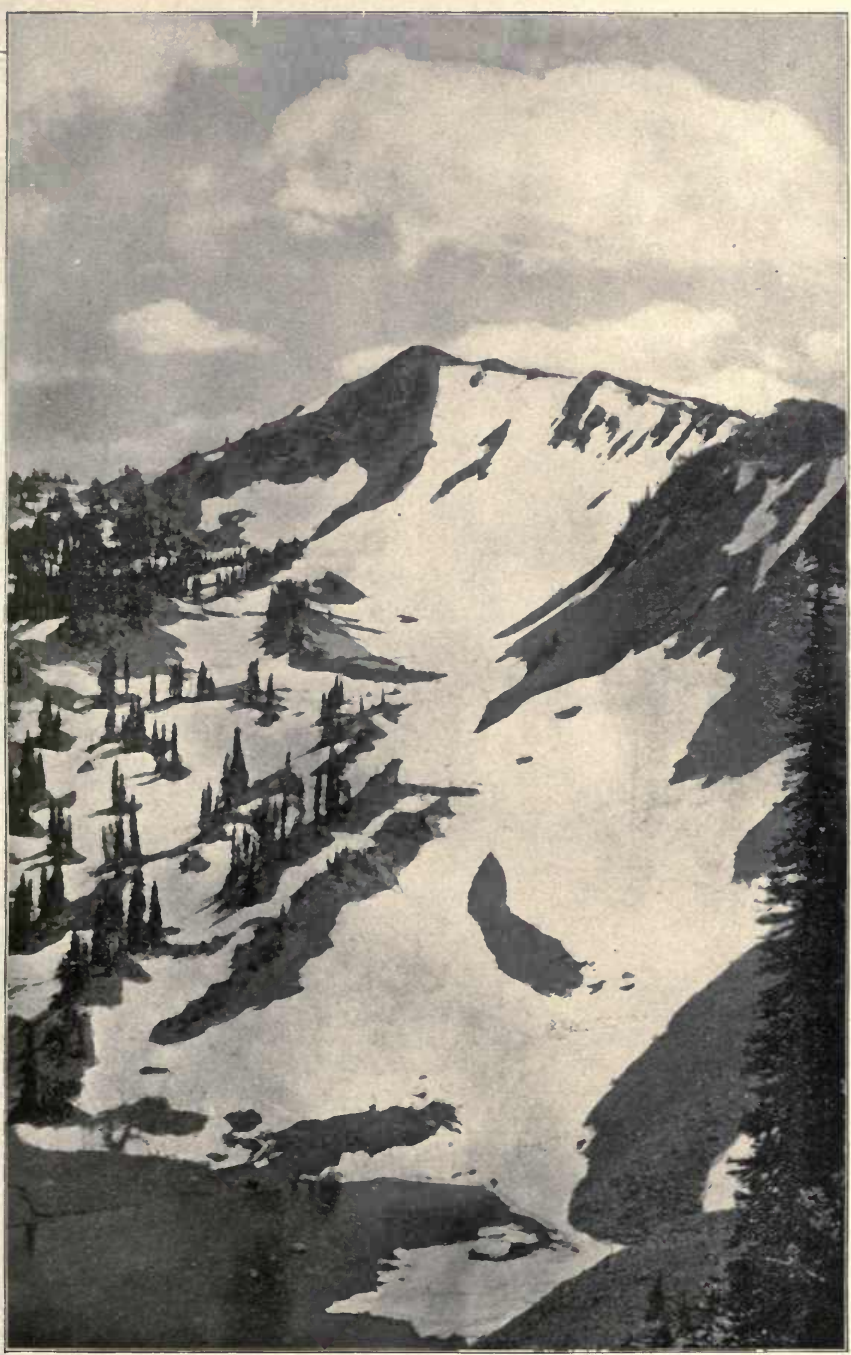

View of MacDougal Peak, Swan Range, Montana, in August, showing typical country for Alpine collecting. The summit is about 7,700 feet. Around the top on sunny days one may always catch an abundance of insects. Photo by M. J. E. 



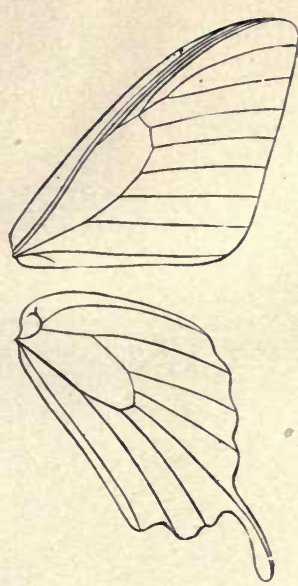

Fig. 16. Venation of Papillo.

\section{SUB-FAMILY PAPILIONINAE.}

Large species, hind wings tailed. Ground color of the wings black, usually marked with yellow, and often with metallic blue or green, or yellow marked with black. Papilio.

Genus PAPILIO, Linnaeus.

Butterfly-There is great diversity of form in the wings of this genus. They are large butterflies, often known as swallow tails. The wings are ample; the fore wings triangular; the hind wings concave next to the body, and usually provided with a tail-like appendage before the anal angle; outer margin dentate. See Fig. 16.

Early Stages-The eggs are somewhat globular, flattened at the base, and smooth. The caterpillars are cylindrical, fleshy, thicker in the anterior portion of the body.

There are about twenty-seven species of this genus found within the limits of boreal America.

\section{KEY TO SPECIES OF PAPILIO.}

1. Ground color yellow, with black bands.

Ground color black, with whitish yellow or white bands.

3.

2. One tail,

Two tails,

rutulus. daunus.

3. One tail; base of fore wings black; an orange lunule with black ocelli on hind winks,

One tail; but little black at base of fore wing, whiter,

One tail; base of fore and hind wings broadly black.

4. Sides of thorax yellow,

Sides of thorax black, eurymedon. nitra. brucei. zolicaon.

D. Row of marginal spots on under side of fore wings blending rutulus Row of marginal spots on under side of fore wings separate 
THE DAUNUS BUTTERFLY OR SWALLOWTAIL.

Papilio daunus, Boisduval, Fig. 17.

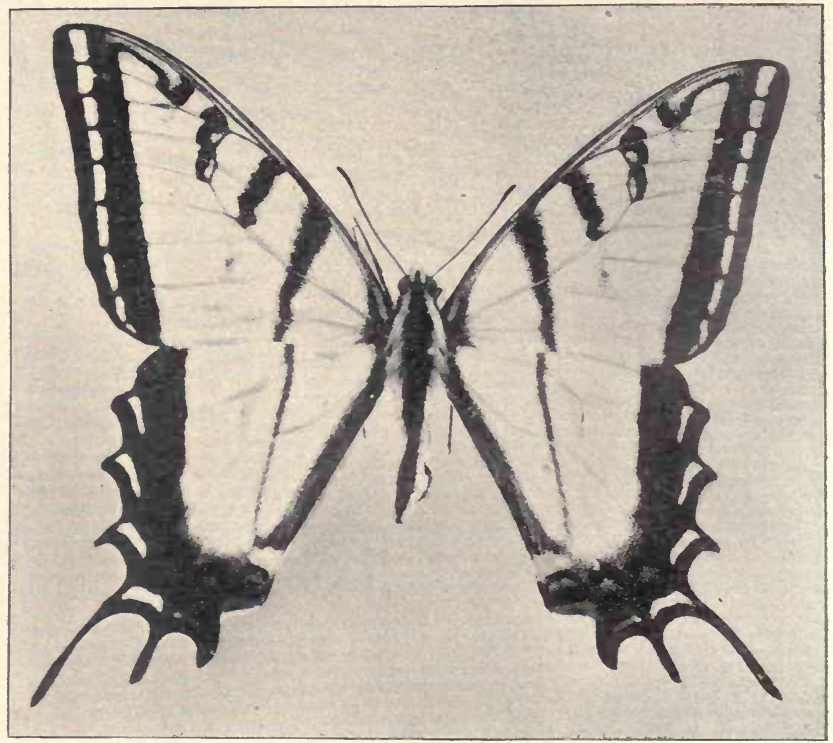

Fig. 17, Papilio daunus.

Butterfly-Expanse 4.00-5.25 inches. Upper surface of wings clear yellow, costa and outer border of fore wings and posterior border of hind wings black. The black along the costa is suffused with yellow, eight spots in the fore and four lunules in the hind wings. The lunule on the hind wings is orange color. There are four black bands on the fore wings. The first is continued two-thirds across the hind wings and is about one-fourth the distance from the base to the outer margin. The second extends from the costa to a little beyond the median vein; the third extends from the costa across the discal cell; the fourth from the costal to the fifth sub-costal venule. The black terminal border of the hind wings contains blue clouds. It has two tails which are black, edged on the inside with yellow. The under side is similar to the upper. The body is black with yellow stripes on each side.

It is the largest of our butterflies, very conspicuous when on the wing, and eagerly sought by the young entomologist. It is apparently absent from the treeless eastern end of the state.

Food-The early stages have not been thoroughly studied, but it is 
allied to the other members of the family. The caterpillar feeds on a great variety of plants.

Distribution-It is found among the eastern valleys of the Rocky Mountains and descends into Mexico. In Arizona it is quite common. In Montana it is on the wing by the last of April. It is very similar to the turnus of the eastern and middle states, but is larger, and with two tails to the wings. It is rather common in the western end of the state, but nowhere abundant. Wiley does not report it from the eastern end, except to refer a specimen on the wing to either daunus or rutulus. Brandegee has taken it at Helena.

\section{THE TURNUS SWALLOW-TAIL.}

\section{Papilio turnus, Linnaeus.}

Butterfly-Expanse of male, 3.00 to 4.00 inches, 75 to $100 \mathrm{~mm}$.; female, 3.50 to 5.00 inches, 87 to $125 \mathrm{~mm}$. This species very closely resembles rutulus, or, rather, rutulus very closely resembles turnus. It may be distinguished by the fact that the marginal spots on the under side of the fore wings are separate, while in rutulus they join together. The species is dimorphic in the female sex in the southern portion of the territory it occupies. At first the black form was regarded as a distinct species, but it is now known that the black and yellow females are of the same species. By experiments it is shown that eggs from yellow females produce black females, and conversely eggs from black females produce yellow females. The dark or black female does not occur in Canada or in the country northward and westward. Holland has obtained specimens of a small dwarfed yellow form near Sitka.

Early Stages-The egg is green or bluish green, with occasionally some reddish spots. The caterpillar feeds on the wild cherry and other plants.

Distribution-It abounds in the wooded regions in the eastern United States, often in great numbers, extending from New England to the Gulf of Mexico. Westward it is found to the Rocky Mountains, extending northward to Alaska. In the state it has been taken by Carrington and Logan in 1871, locality not given.

Several specimens of turnus are among Wiley's specimens in his Miles City collection. 
THE RUTULUS BUTTERFLY.

Papilio rutulus, Boisduval, Fig. 18.

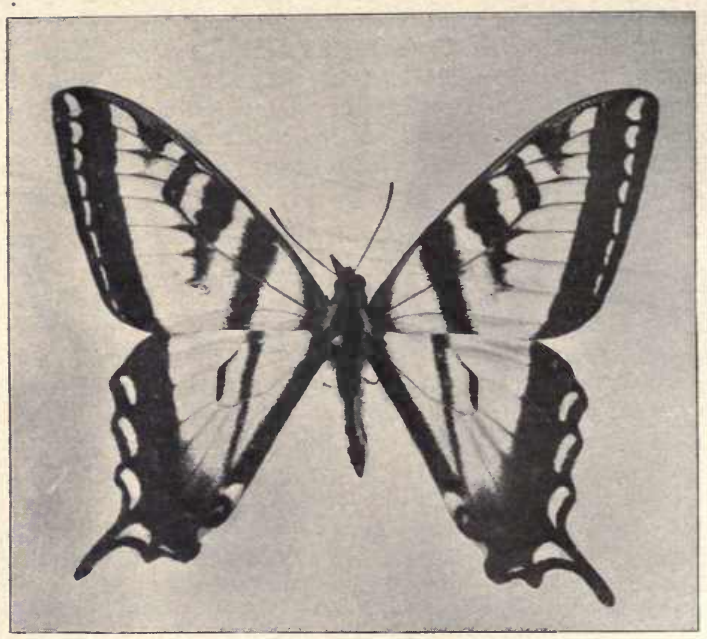

Fig. 18, Papilio rutulus.

Butterfly-It resembles P. daunus in color and markings, but the black bands are broader and it has not the two decided tails. The marginal spots on the under side of the fore wings run together, forming a continuous band. Expanse, male, 3.50-4.00 inches; female, 3.75-4.25 inches, 94 to $106 \mathrm{~mm}$.

This species also closely resembles P. turnus, and displaces turnus on the Pacific Coast. It is not uncommon. At Missoula it flies as early as May 10. At Swan lake it is abundant in June. It is found as high as 6,100 feet at Missoula.

Food-It feeds on alder and willow, which are very abundant along all Mountain streams.

Distribution-It is a Pacific species. Found throughout the western part of the state. Not reported at Miles City, except as mentioned under daunus. Brandegee reports it from Helena. It is fairly common at Bozeman, according to Cooley. 
THE EURYMEDON BUTTERFLY.

Papilio eurymedon, Boisc'uval, Fig. 19.

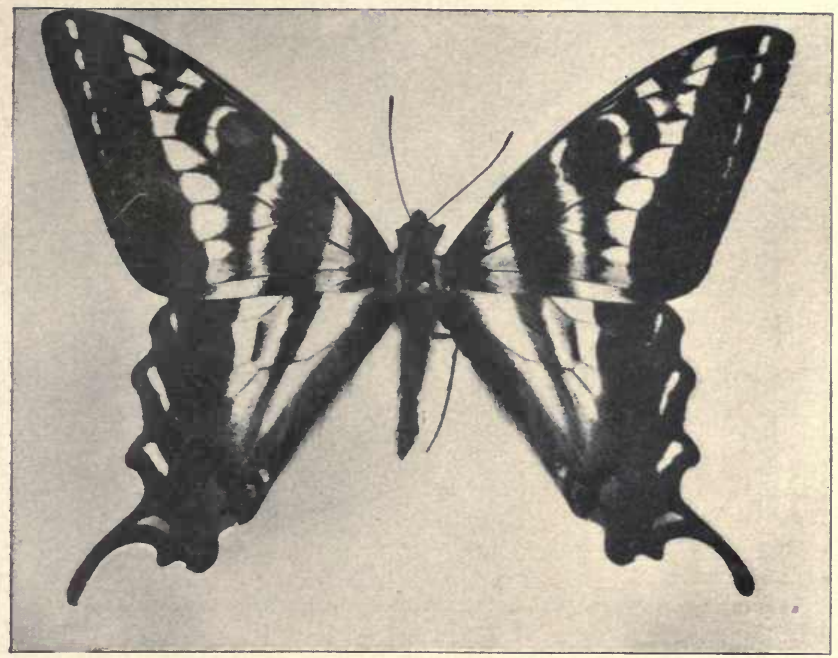

Fig 19, Papilio eurymedon.

Butterfly-In the style of its marking it resembles $P$. daunus, but the ground color is always pale whitish yellow or white, and the white marginal spots on the under side of the fore wings continuous as in P. rutulus. Expanse $3.50-4.00,87-100 \mathrm{~mm}$.

In the western part of the state it is the most abundant species, flying as early as April 30, and taken through May, June and July.

Food-The caterpillar resembles $\mathbf{P}$.turnus, but may be distinguished by its paler color and the much smaller spots composing the longitudinal series on the back and sides, and by the different color of the head. It feeds upon a variety of plants, and is especially partial to Rhamnus californicus.

Distribution-The species ranges from Mexico to Alaska, eastward to Colorado. It is abundant in the valleys of the Coast ranges, and is very common in the canyon of the Frazer river, British Columbia, in June. Common, though not abundant, around Missoula, and taken in the Mission mountains and at Swan lake. It has been taken at 6,000 feet at Helena by Brandegee. At Bozeman it is not very abundant (Cooley). Wiley has one specimen from Miles City. 


\section{BRUCE'S SWALLOWTAIL.}

Papilio brucei, Edwards, Fig. 20.

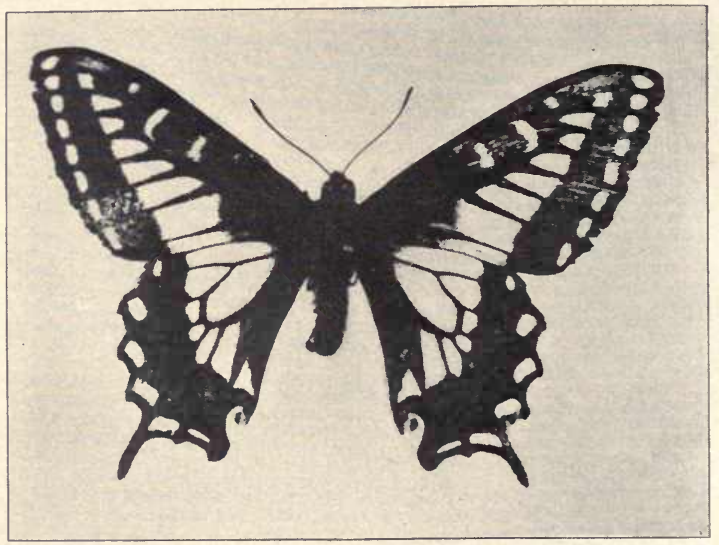

Fig. 20, Papilio brucei.

Butterfly-Expanse 3.25-3.60 inches. Under surface yellow, with black borders, the same as in P. daunus. The base of the wings is black and it extends in such a way as to make the discal cell appear black with three yellow bars. It has the yellow spots in the black along the costa. It has one tail, and black marking on the veins. The last lunule in the hind wing is orange with a black ocellus. The hind wings have the blue clouds. The body is black. It is thought to be the result of a union between P. oregonia and P. bairdi.

Food-The caterpillar feeds on Umbelliferae, and is common on parsley and parsnips in gardens.

Distribution-In Colorado and adjacent regions P. oregonia meets with the form bairdi which ranges northward from Arizona. Hybridization is thought to have occurred, resulting in the fixed form brucei, breeding either toward bairdi or oregonia. Oregonia is found in Oregon and Washington, where bairdi is absent. We formerly captured a specimen identified by Edwards as oregonia and another as bairdi near Idaho Falls, which lends support to the hybridization idea. We have sought for oregonia in Western Montana, but have found none which could be so called. Most of our specimens have been taken from Missoula. One was taken in the Mission mountains. Cooley has specimens from Bozeman, thought to be zolicaon. Possibly Wiley's zolicaon may be brucei. 
THE ZOLICAON BUTTERFLY.

Papilio Zolicaon, Boisduval, Fig. 21.

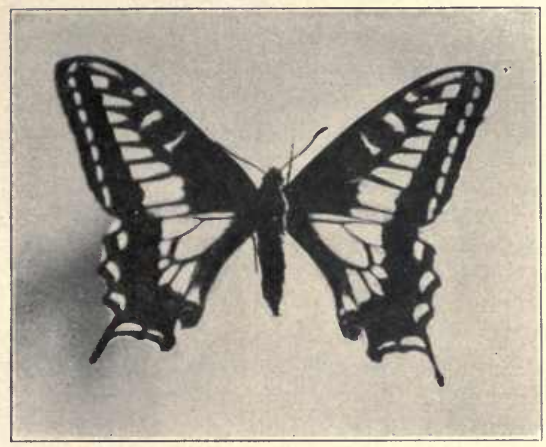

Fig. 21, Papilio zolicaon.

Butterfly-Expanse 3.25-3.75 inches. Upper side of primaries black, marked and spotted with deep yellow; of secondaries yellow from base nearly two-thirds the distance to margin, beyond black; primaries have a sub-marginal row of eight spots, and a discal series of eight forming a band across the entire wing; the first discal spot excavated on the upper side, sometimes divlded into two. Secondaries with a broad black border which incloses a sub-marginal series of six yellow spots, the first often wanting; an orange or deep fulvous spot, inclosing a round or oval or black spot, and edged on the upper side by a blue crescent, the ring occasionally wanting; the rest of the wing yellow, divided into eight spots, the cell being one, by the black nervures. Under side nearly as above, the colors paler. celery.

Food-The caterpillar feeds on the Umbelliferae, fennel, carrot and

Distribution-Southward from Vancouver's Island to Arizona, eastward to Colorado. Reported by Wiley to be rare at Miles City. Collected by Dr. Hayden in Montana in 1871.

\section{THE NITRA SWALLOWTAIL. \\ Papilio nitra, Edwards.}

Butterfly-This butterfly is very nearly related to zolicaon, but the black is widely spread over the base of the wings so as to make the yellow appear like a broad band, and the two yellow bars in the fore wings are very indistinct.

Holland reports this insect rare in collections, and says it has sprung from the same original stock as zolicaon and aliaska, the latter being an offshoot from the Asiatic butterfly. We have not seen the species.

Food-Early stages and food unknown.

Distribution-It occurs in Montana and the portions of British America adjacent on the north. 


\section{FAMILY PIERIDAE.}

Small or medium sized; hind wings not tailed; white or yellow in color; with dark marginal markings.

Pierinae.

SUB-FAMILY PIERINAE (The Sulphurs and Whites.)

Medium sized or small butterfly, white or yellow in color, with dark marginal markings. In many genera the sub-costal vein of the fore wing has five, or even six nervules, and the upper radial is lacking in this wing. The eggs are spindle shaped, marked with vertical ridges and cross lines. The caterpillars are cylindrical, generally green in color. The chrysalids are generally more or less jointed at the head.

\section{Key to Genera.}

1. Antennae abruptly terminating in an ovoid elub.

Abtennae terminating in an obconic club.

2. Abdomen shorter than the hind wings; color white or very pale yellow.

3. Underside of hind wings without marks, or marked along the veins; size, medium.

Pontia, P. 27

Underside of hind wings marked with a greenish net-work; small size.

Synchloe, P. 3:

4. Hind wings with an orange discal spot, both wings with black border

Eurymus, P. 37

Medium sized; costa black as far as the end of the cell; transparent white wings; apex black with white spots.

Neophasia, P. 26

\section{Genus NEOPHASIA Behr.}

Butterfly-Medium size, white in color. The upper radial is lacking, and the sub-costal is provided with five branches, the first emitted well before the end of the cell.

Early Stages-The egg is flask shaped. The caterpillar in its mature form is about an inch long. The body is cylindrical; terminating in two short anal tails. The color is dark green, with a broad white band on each side. But one species is known.

\section{Key to Species.}

Almost a transparent white, a black border to fore wings, and a black bar across the discal cell, meeting the border, menapia.

THE PINE WHITE.

Neophasia menapia Felder. Figs. 22, 23.

Butterfly-Medium sized; hind wings white with dark veins on the under side; black and white apex. 


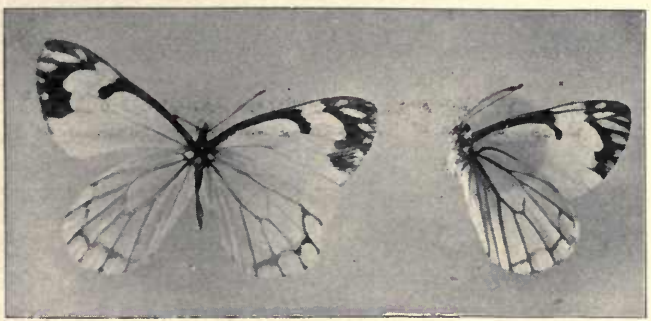

Fig. 23. Neophasia menapia.

Early Stages-Described by Edwards. "The caterpillar infests the pine trees and firs of the northern Pacific States. The larva lets itself down by a silken thread, often a hundred feet in length,

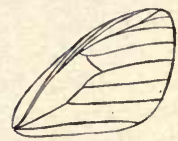
and pupates on the ferns and shrubbery at the foot of the trees. It sometimes works great damage to the pine woods."

Distribution-It does not seem abundant in the west end, but has often been seen in the Mission mountains and about the laboratory at Big Fork high up in the coniferous trees out of reach of the collector. At Swan lake it was found rather abundant late in August, 1903. In Auguist, 1904, about 40 were taken in a half hour, about half way up the lake. The collecting region at Swan lake for this species is along the lower half of the Fig. 22. Venation of lake shore. Very few have been seen around the upper end.

\section{Genus PONTIA FABRICIUS.}

(The Whites). Fig. 23.

Butterfly-White, more or less marked with black, occasionally the white is tinged with yellow. The outer margin of the primaries is straight, the outer margin of the secondaries is more or less evenly rounded. The egg is spindle shaped. The caterpillar is elongate, the head hemispherical. The chrysalis is attached by the anal extremity, and held in place by a silk girdle.

\section{Key to Species.}

1. Fore wings with a black bar at the end of the cell, and more or less of a black border,

Fore wings with no black bar at the end of the cell.

3.

2. Markings on under side concentrated in brownish blotches,

protodice.

Markings on under side of hind wings green blotches on the disk, beckeri.

Markings on under side as rays on either side of the veins, occidentalis.

Veins of fore wings black, spots smaller. sisymbri. 
3. Under side of hind wings plain yellow. No marks along the veins,

Under side of hind wings marked along the veins,

rapae.

4.

4. Black border to both wings,

monuste.

No black border to wings,

5. Under side of hind wings pale yellow, with brownish along the veins,

nap1.

THE PROTODICE BUTTERFLY, OR SOUTHERN WHITE.

Pontia protodice Bois. and LeConte. Fig. 24.

Summer form, protodice, Bd. and Lec. Expanse of wings from 1.6 to 1.8 inches, 40 to $45 \mathrm{mim}$.

Male. Upper surface white, fore wings with a broad black dash or bar across the end of the discal cell, and a sub-marginal row of three

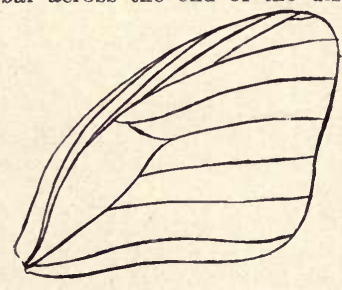
more or less distinct spots, the last almost or quite touching the hind margin. Traces of rays run from this row to the outer edge. Hind wings without spots. Bars and spots are repeated on the under side. Veins of hind wings are broadly marked with greenish yellow sprinkled with brown seals, and the tips of the fore wings tinged with greenish yellow.

Female. Color and spots as in male, but the spots have a tendency to blend, and the outer margin supports a border of triangles connecting with the sub-

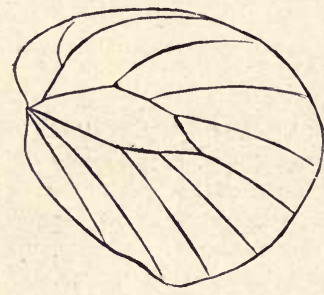

Fig. 24. Venation of Pontia. (P. protodice) terminal row of rays. Hind wings with subterminal zigzag blackish line, outer portions sending rays to the margin, where they are somewhat expanded. The base of both wings are more sprinkled with dark scales than in the males. Under side similar to that of the male.

Winter form, vernalis, Edw. Smaller than summer form, the dark colors more prominent. Spots of subterminal row of fore wings more inclined to be connected. Expanse scarecely 1.6 inches. Body black, with some white hairs and scales.

Distribution-This insect is usually known as the Southern Cabbage butterfly, though it is to be found everywhere east of the Rocky mountalns. It is injurious in the larval state in the southern states. In the northern states $P$. rapae is more common, in many places driving out protodice. There are several broods during a season.

Wiley has taken it at Miles City; Brandegee has collected it at Helena; Cooley has it from Bozeman; Douglass collected it in the Ruby Mountains and Madison Valley; Elrod has taken it at Missoula, Flathead Lake, and in the Mission Mountains, Coubeaux has it from Big Sandy. Collected by Coues along the 49th parallel in 1874 . 


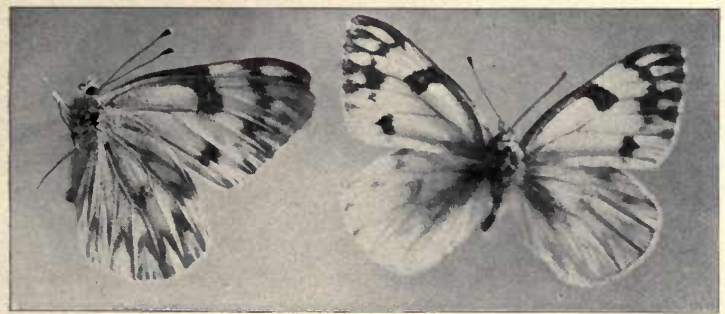

Fig. 25, Pontia protodice.

Its food consists of cruciferous plants. It is destructive to cabbage.

THE WESTERN WHITE, Pontia occidentalis Reakirt,

Butterfly-Size about 1.75 inches, distinguished from P. protodice by its smaller size and different markings. On the under side of the wings the dark markings are not concentrated in blotches, but are in broad longitudinal rays on either side of the veins from the base to the outer margin. Spots on the upper side much smaller than in protodice, and fewer. The females are sometimes lemon yellow above.

Early Stages-Similar to those of protodice.

Distribution-It is found from the Rocky Mountains to the Pacific. Wiley has it in his collection from Miles City; Cooley has taken it at Bozeman; Brandegee at Helena; Douglass at Madison Lakes; Elrod at Missoula, and on MacDougal Peak. It is likely to be found any place in the state. Allen has taken it at Dillon. Coues collected it in 1874 along the 49th parallel.

THE CABBAGE BUTTERFLY. Pontia rapae, Linnaeus. Fig. 26.

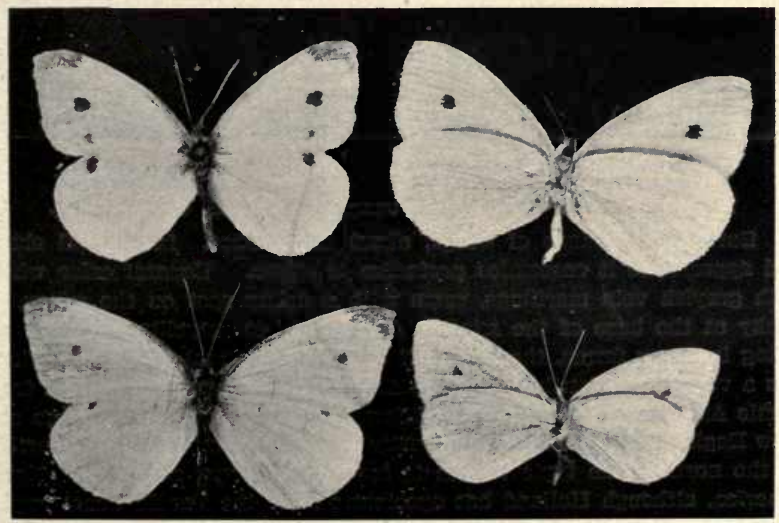

Fig. 26. Pontia rapae; upper figures show both surfaces of female, lower figures same for male. 
Butterfly-Known as cabbage butterfly; yellowish white, with apex of fore wings black. Two black spots on fore wings and one on the hind wings. Underneath, the apex of the fore wings and the entire surface of the hind wings are pale lemon yellow. In the female two spots on outer part of fore wings, in male only one.

The larva feeds principally on cabbage. Its color is green like the cabbage leaf, with a narrow greenish lemon yellow dorsal band. The body is clothed with very fine short hairs.

Distribution-This common species is an importation from Europe. It reached Quebec in 1860; how, no one knows, perhaps in cabbage. By 1881 it had spread over the eastern half of the continent, from Hudson Bay to Southern Texas. In 1886 it had reached Denver, and in $1884 \mathrm{had}$ reached the head waters of the Missouri. It now possesses the cabbage fields from the Atlantic to the Pacific, "to the incalculable damage of all who provide the raw material for sauerkraut." The injury done by the caterpillar is estimated to amount to hundreds of thousands of dollars.

It is probably to be found all over the state, and has been taken at almost every place where collections have been made, at Missoula, Miles City, Bozeman, Helena, University of Montana Biological Station at Flathead Lake, Mission Mountains. It does not seem as common as P. protodice. Allen collected it at Dillon.

THE MUSTARD WHITE.

Pontia napi Linnnaeus. Fig. 27.

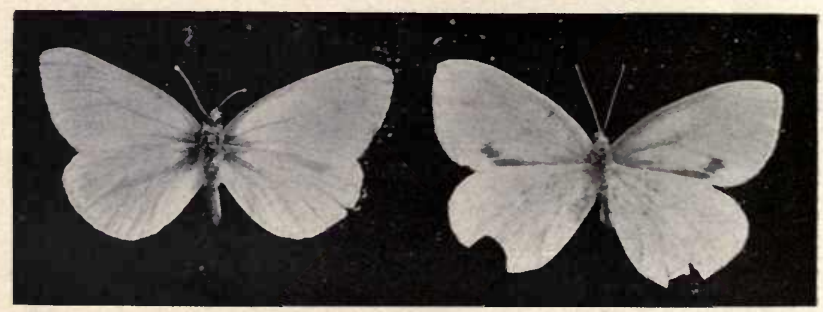

1

2

Fig. 27. Pontia napi, No. 1, var.pallida No. 2, var. acadica.

Butterfly-Expanse of wings, about 1.75 inches. In general shape and appearance it resembles protodice or rapae. General color while, with grayish vein markings, some with a dusky spot on the wings, or dusky at the base of the wings. A Protean, cosmopolitan species, existing in many forms, the result of climatic and local influences, which has a very wide distribution. The different forms are to be found from Arctic America as far south as California on the west, and Michigan and New England on the east. It is mostly represented in the regions farther to the north. The typical form is found in Europe, rarely in North America, although Holland has specimens from the Pacific Coast region 
whlch he says are absolutely indistinguishable from European specimens in color and markings.

Var. pallida, Scudder. The wings are white above and below, with small black spot on the fore wing of the female above, and hardly any trace of dark shading along the veins on the under side; a trace of dark on the hinder edge and base of fore wings. One specimen taken at Flathead Lake, August, 1903. One taken in the big meadows at the upper end of Swan Lake, August 8, 1904.

Var. acadica, Edwards. The veins of the wings have narrow border above and below of blackish, more pronounced in the female, base of wings and sometimes the tips dusky. The under side in both sexes and the upper side in the female are distinctly yellowish. Specimens from Montana have been examined as follows: One from Helena (Brandegee) June 26, 1902; four from Missoula, one April 28, 1900, one June 1, 1900, one June 121899 one October 1897; one from Bozeman (Cooley); three from Miles City (Wiley).

\section{THE CALIFORNIA WHITE.}

\section{Pontia sisymbri, Boiduval Fig. 28.}

Butterfly-Expanse of male, 1.2 to 1.6 inches, 33 to $40 \mathrm{~mm}$; female, 1.6 to $2.00,40$ to $50 \mathrm{~mm}$. Upper side of male white with a faint yellow tint; bases of wings dusted with black; primaries have the costal margin gray for three-fifths the length from base; the ends of the nervules from

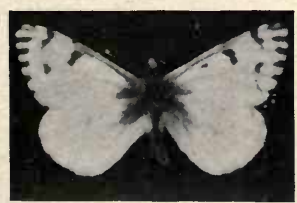

Fig 28. Pontia Sisymbri. black at the ends of the veins.

Under side same color; the markings repeated, but paler or gray, the bars along margin of primaries greenish-gray.

Body gray above, thorax white below, abdomen yellowish; legs white, palpi white with black hairs in front; antennae black above, whitish beneath; club black, the tip orange,

Female similar to male.

Early Stages-The eggs are long, narrow, conical, the base and top flattened, depressed; ribbed longitudinally, and crossed by numerous striae; color when first laid yellow, shortly before the end of the stage red. Mature larva about .9 inch, $25 \mathrm{~mm}$., color light yellow crossed with stripes of black. The caterpillar feeds upon the cruciferae.

Distribution-Found in Colorado and the Pacific states. Collected by Elrod at Missoula. 


\section{BECKER'S WHITE.}

\section{Pontia beckeri, Edwards.}

Butterfly-Expanse, 2 to 2.2 inches, 51 to $56 \mathrm{~mm}$. Easily discriminated from all other allied species by the green markings on the under side of the hind wings, concentrated in broad blotches on the disk; by these markings the species recalls the species of the genus euchole.

Male. Upper side pure white; base of wings not powdered with black, as in allied species; at the outer edge of the cell a dense black subrectangular spot (not reaching the costa), with a central white streak. Secondaries immaculate.

Under side white; the veins at apex and on upper hind margin bordered by black scales and suffused with greenish yellow; cellular spot enlarged, its base broadened and posterior edge excavated.

Secondaries have all the veins and branches yellow; those terminating on hind marg, $\mathrm{n}$ edged by broad bands of yellow green reaching to middle of disk and connected anteriorly; three large spots of same color about the cell; another large triangular subapical spot on costa; the veins at base banded with green; all these bands and spots slightly sprinkled with black scales.

Body above gray, yellowish beneath abdomen, white beneath thorax; legs white; palpi white, grey on upper side and at tip. Antennae white above and at base below, beyond brown; club black, tip pale fulvous.

Female. Similar to male, but with larger and more numerous spots; secondaries with black spots and dark streaks along the veins; under side with a round black spot in submedian inter-space on primaries, in addition to discal black spot.

Early Stages-The mature larva is 1.25 inches, $32 \mathrm{~mm}$. long, greenish white, thickly marbled or sprinkled with gray, and with a very distinct orange belt between the segments; each segment also has 16 or 18 jet black tubercles which taper into black bristles; the head is tinged with yellow. It feeds on cruciferous plants.

Distribution-From Washington to Central California, east to Colorado. Taken in the state by Ccoley at Bozeman, and by Allen at Dillon.

\section{Genus SYNCHLOE, Huber.}

(Euchloe-Anthocharis.) Fig. 29.

Butterfly_Small butterflies, white in color, with the apical region of the primaries dark-brown, marked with spots and bands of yellowish orange or crimson. On the underside the wings are generally more or less profusely mottled with green spots and striae.

Egg-Spindle shaped, laterally marked with raised vertical ridges, between which are fine cross lines. small.

Caterpillar-In its mature stage, it is relatively long, with the head

Chrysalis-With the head relatively projecting; wing cases compressed.

\section{Key to Species.}

1. Orange apex, surrounded by black; lower surface of hind wings complete grøen network, No orange at apex of fore wings, 
2. Having the tips of wings marked with gray; a conspicuous bar at the end of the cell,

3. Under side; apex of fore wings with many green scales; hind wings with a network of greenish yellow scales. creusa.

Under side; apex of fore wings with a few green scales; hind wings crossed with several green bands, outer one trifid,

olympia.

Under side; hind wing with three irregular bands, outer one much forked, ausonides.

THE AUSONIDES ORANGE-TIP.

Synchole ausonides Boisduval. Fig. 30.

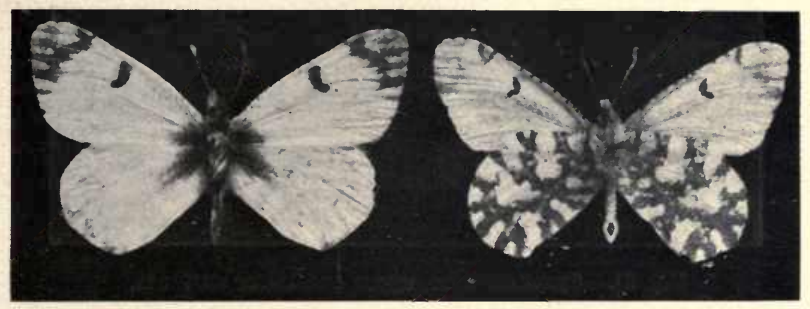

Fig. 30. Synchloe aussonides.

Butterfly-Fore wings greenish beneath; hind wings marked with three irregular green bands, the outer one forking into six or seven branches toward the outer and inner margins. Expanse ,1.65 to 1.90 inches, $41-48 \mathrm{~mm}$.

Early Stages-Caterpillar pale whitish green, with dark-green longitudinal strips on the side and back. It feeds on cruciferous plants.

Distribution-It ranges from Arizona to Alaska, eastward to Colorado. Brandegee reports it common at Helena. It is one of the most abundant insects about Missoula in the spring, although not so abundant as sara. 
THE SARA ORANGE-TIP.

Synchloe sara, Boisduval, Fig. 31.

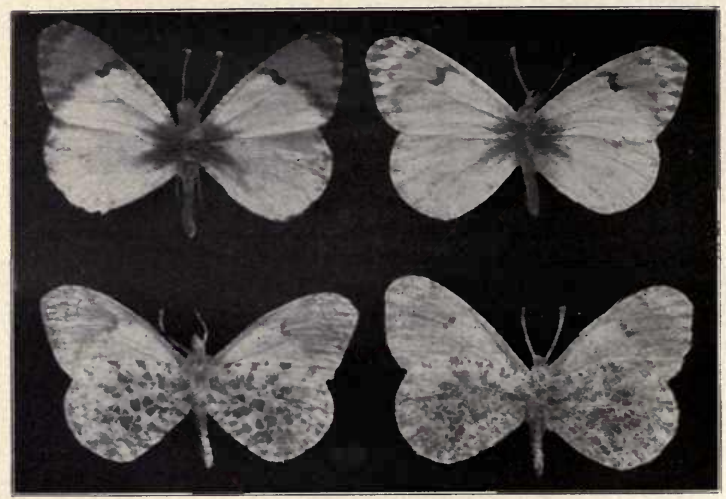

Fig. 31. Synchloe sara, upper and lower surfaces.

Butterfly-White with orange tips. There is a black bar dividing the apical patch. The female is sometimes yellow instead of white. On the under side the hind wings are marked with dark irregular patches of greenish brown scales, loosely scattered over the surface, and having a "mossy" appearance. There are different varieties.

Early Stages-Unknown.

Distribution-This species in all its forms belongs to the Mountain States of the Pacific Coast. It is abundant around Missoula, where it seems to thrive. The mountain slope back of the University is a favorite field, as it faces the west, catching the warm rays of the sun in spring. Here dozens may be captured in a short time. It is common around Helena (Brandegee) and about Bozeman (Cooley).

Var. julia, Edwards, in which the black bar dividing the red apical patch from the white on the remainder of the wing is broken, or tends to diminution at its middle, is reported by Brandegee as common at Helena.

Variety reakertii is smaller than sara, with dark spots at the ends of the veins of the hind wings. Taken by Brandegee at Mt. Ascension, near Helena. 
THE OLYMPIA ORANGE-TIP.

Synchloe olympia $\Sigma$ dwards. Fig. 32.

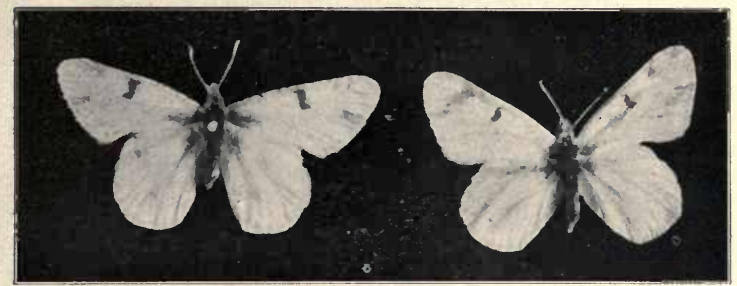

Fig. 22. Synchloe olympia.

Butterfly-Expanse. about $\mathbf{1 . 2 5}$ inches. Upper surface white, gray at base of wings; a large gray patch at the apex of the fore wings, partially replaced by white. Costal margin slightly specked with black; a black bar at the end of cell. The hind wings have a few black scales at the outer angle and a small wedge-shaped black spot near the base on the costa. Under side white. The fore wings have a small gray subapical patch on the costa, nearly covered with green scales, and a faint greenish patch on the outer margin. Discal spot narrow, lunate, enclosing a white streak.

Hind wings crossed by bands of yellow-green on a gray ground. The one near the base is slightly trifid on the costa, the outer one broadry trifid, but running from the outer margin instead of the costa, the middle and outer one joined on the median vein. There is also a spot of the same color between the anterior ends of the second and third.

Body black above, the under side white, the thorax tinged with greenish yellow.

Early Stages-The caterpillar is striped lengthwise with pale slate color and bright yellow; feet, legs and head grayish green. The food plants are the cruciferous species.

Distribution-Found from West Virginia to the Rocky Mountains, and from Montana southward to Texas. In Montana collected abundantly by Wiley at Miles City; taken by Cooley at Bozeman, and by Barnes at Aldridge. 


\section{Butterflies and Fairies.}

Lily Mordaunt in "Kenelm Chillingly" had some beliefs that make her too fanciful for a real character. One of the most conspicuous of these was her idea about butterflies. She had a green-house inclosed with wire and covered with vines and draperies, into which she put every butterfly she could catch. Butterflies to her were not insects, but the souls of infants who had died unbaptized. If they were taken care of for a year they turned to fairies. So she fed and tamed her colonies of butterflies, releasing them when she believed their year of life completed, that they might be free to change into fairies.

NELLIE A. WHITNEY. 
Butterfly-Wings above rather pale greenish yellow, outer borders black; border of female is broader than in male, and contains a submarginal row of yellow dots; discal spot in the male is elliptical; antennae, costa and fringes roseate; a submarginal row of dots on the under side, the last three on the fore wings black, the remainder brown with pink scales. Dimorphic females occur with wings nearly or quite white, and also a black form. Expanse 1.75, 2.25 inches, 38-57 mm.

Early Stages-The food plant is clover. The eggs are pale yellow, changing after being laid to crimson. The caterpillar is slender, green, striped longitudinally with paler green. The chrysalis is pale green.

Distribution-The species ranges from New England to Florida and westward into the Rocky Mountains. The collection at the University of Montana contains specimens from Missoula, Fish Creek, McDonald Lake in the Mission Mountains, Lo Lo Hot Spings, Flathead Lake, Madison Valley, National Park and Mount Lo Lo.

Remarks-It is one of our common butterflies. It shows many variations in size, coloration and markings. We have despaired of separating the males of philodice, eurytheme and alexandra, so much are they alike, and so much do they vary. It would at first seem as though philodice should not be found west of the range, but specimens from Flathead Lake are indistinguishable from those in the eastern end of the state; and if the labels of Montana specimens were exchanged with those collected by Wiley and the writer from Iowa, Michigan, Illinois, and Missouri the difference could not be told. The large series (about 100) of insects of this species in the University collection shows that the species in markings and coloration apparently merges into Eurytheme, and it has often occurred to us that they may possibly overlap.

THE EURYTHEME SULPHUR.

\section{Eurymus eurytheme, Boisduval. Plate IV.}

Butterfly-Expanse of wings 2 to 2.35 inches, $50-90 \mathrm{~mm}$. Closely resembling philodice in size, shape and markings, but color orange, of varying shades, instead of yellow. Male usually orange-yellow, shading to sulphur yellow on the costa of both wings and on inner margin of hind wings, base and inner margin sprinkled with black scales; outer border black, broadest at apex; anterior veins yellow where they cross the black; width of border about one-fourth the length of wing; discal spot black on fore wings, orange on hind wings, usually with two spots in the latter; both wings have roseate reflection; under side yellow, middle of fore wings tinged with orange; on both wings a sub-terminal row of dots, the three posterior of fore wings black, the remainder brownish, also two dots on costa near apex; discal spots repeated, the anterior black, with a few light scales, posterior gemmate, silvery, annulate with roseate brown or ferruginous; a dash on the costa of the hind wings near the apex, and a rosy spot at the base.

Female of same general color; border contains a row of yellow spots, the third from the posterior and on fore wings sub-obsolute; border of hind wings wider than in male, and with rudiments of yellow spots; under side similar to that of male. 


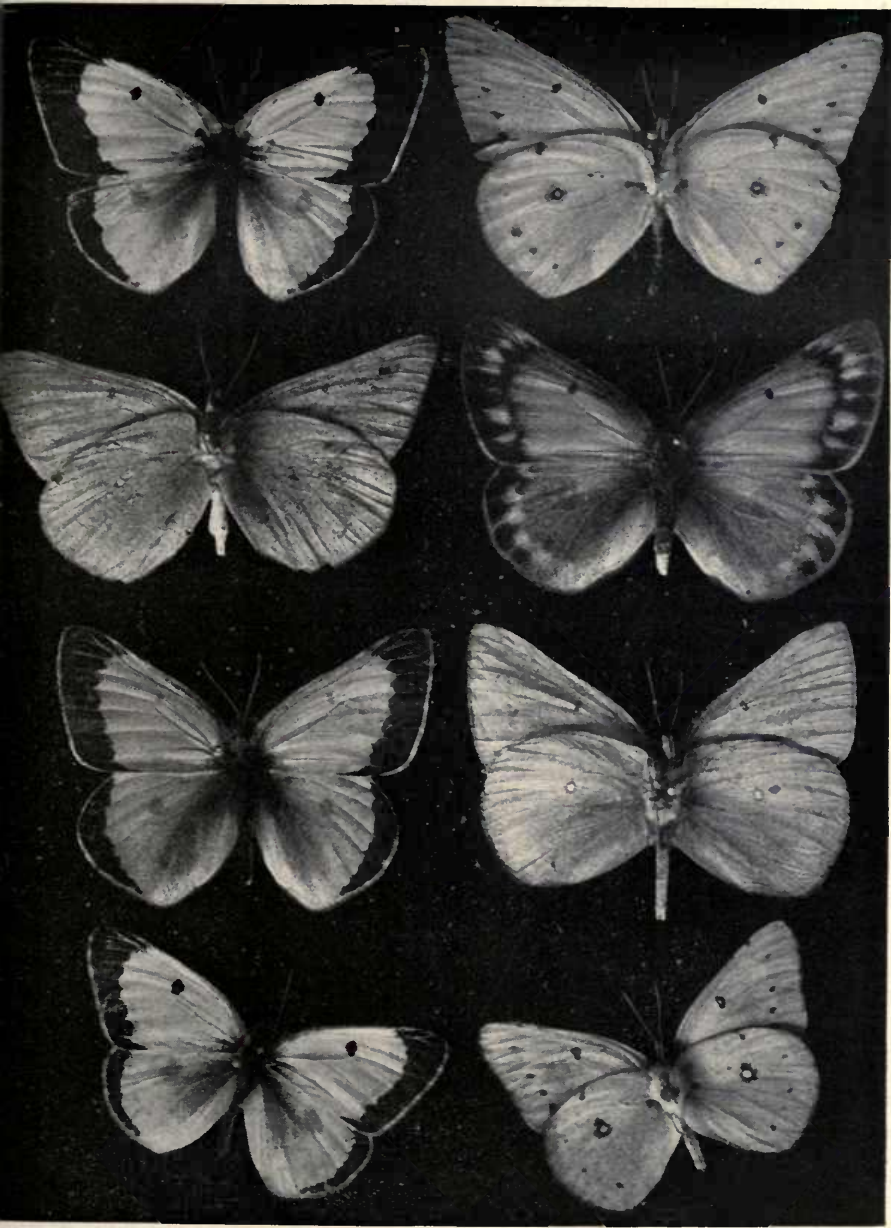

Eurymus eurytheme, 3, under side; 4 , upper side of female; 1, upper side of male; 2 , lower side of female, form keewayden; 5 , upper side of male; 6 , lower side of female, form meadii; 7 , upper side of male; 8 , lower side of female, form ariadne. 

A white or albino female, Fig. 35, is sometimes found with all the markings as in the yellow form, white replacing the yellow. There are the following seasonal and local variations from the typical form.

Form aridadne, Edwards, Plate IV, emerging from winter chrysalis, has the fore wings tinged with orange, a spring form. Expanse, 1.75 inch, $45 \mathrm{~mm}$.

Form keewaydin, Edwards, Plate IV. Larger than preceding, more deeply flushed with orange, a winter form. Expanse, $1.85 \mathrm{inch}, 48 \mathrm{~mm}$.

Form eriphyle, Edwards, yellow, not laved with orange, summer form. Expanse, 2.00 inch, $50 \mathrm{~mm}$.

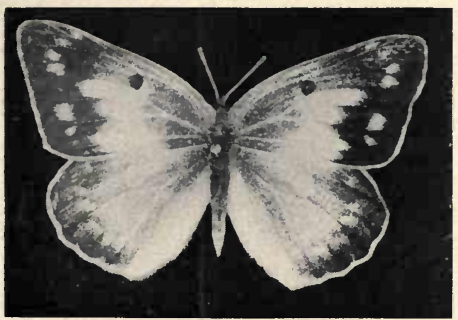

Fig. 35. Eurymus eurytheme, albino, female
Albinos have been taken at Flathead lake on the west side and at Fish creek east of the range, with expanse of wings 52-55 $\mathrm{mm}$.

Early Stages-Egg .06 inch long, narrow, fusform, ribbed lengthwise, crossed by numerous striae; color buff-white when deposited, changing to crimson, then to black; mature larva from 1.1-1.2 inches, 26-28 $\mathrm{mm}$. in length, dark green, with band of pure white with crimson line; chrysalis with anterior part and wing cases dark green, abdomen yellow-green; the food plant is clover.

Distribution-The range of eurytheme is very wide. It extends from the Atlantic to the Pacific, and from Canada to the far south, though it is rare in the south. It has been collected in the state by Elrod at Flathead Lake, Missoula, Mission mountains, Dodge Mountain at 7,400 feet, and Mount Lo Lo. Douglass has taken it at $\mathbf{F}$ ish Creek, Laurin, Ruby mountains, Tobacco Root range, and Madison valley; Wiley has collected it at Miles City, Brandegee at Helena and Gold Creek, and Cooley at Bozeman. It is found in all parts of the state, and will be one of the first specimens captured by the young entomologist. The reader is referred to "Remarks" under philodice. Coubeaux says form eriphyle is very common near Big Sandy. Allen has taken eriphye, ariadne and keewayden at Dillon. Coues collected keewayden and eriphyle along the the 49 th parallel in 1874 . 
THE ALEXANDRA SULPHUR. Eurymus alexandra, Edwards, Fig. 36 .

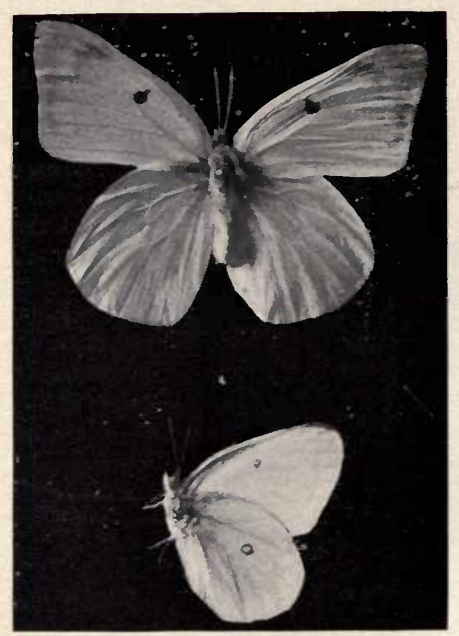

Fig. 36 Eurymus alexandra, female with expanded wings; male showing uncer side. From specimens taken at Bigfork.

Butterfly-Expanse of wings of females $2-2.3$ inches, $50-60 \mathrm{~mm}$; of males, 1.75 inches, $45 \mathrm{~mm}$. Male pale canary yellow, the black border much narrower than in philodice or eurytheme; a fine yellow line borders the black on outer margin; base of wings, thorax and abdomen with considerable black; anterior of thorax, antennae and legs roseate; under side of fore wings much paler than upper, uniform; under side of hind wings pale greenish gray, sprinkled with black scales; discal cell of hind wing silver, without rings; black border above showing through wing from below. Female larger than male, without black border above; sometimes the apex of fore wings is sprinkled with black, giving indications of markings; wings paler than in male, sometimes almost white; discal spot in fore wings black, oval, sometimes with yellow splash in the middle; on hind wing orange yellow, usually double; under side, silvery gray, yellow only at the base and on inner margin of the primaries; discal spot of hind wings silvery, with brown margin. Discal spot of fore wing dark brown with light spot in center; the roseate of the male repeated on the female, continuing around the outer border of the wings.

Early Stages-Caterpillar uniformly yellowish-green, with a white band on each side, broken with orange dashes running through it. The chrysalis resembles that of philodice, is yellowinsh green, darkest on the 
dorsal side, and adorned with three small red dots on the central side of the abdomen near the wing cases. The caterpillar eats Astragalus, Thermopsis and white clover.

Distribution-The species is found in Colorado and the Mountain region to the north and west of that state. In Montana it has been taken at the University of Montana Biological Station at Bigfork, in 1903, at Flathead lake. It is not common, and is rather difficult to catch, as it keeps to the bushes and does not rest often. Brandegee has collected it at Alhambra. A single frazzled and battered female was taken by Elrod on MacDaugal Peak in the Swan range at 6,500 feet August 4, 1903, and another August 1, 1904.

\section{SCUDDER'S SULPHUR.}

Eurymus scudderi, Reakirt.

Butterfly-Expanse, 1.80 to 2.00 inches, 45 to $50 \mathrm{~mm}$. Similar to alexandra. The male on the upper side is colored like c. pholidice, but the black borders are much wider. The fringes are rosy. The female is generally white-very rarely slightly yellow-with very pale dark borders, or often without any trace of black on the outer margin of the wings. On the under side the apex of the fore wings and the entire surface of the hind wings are greenish gray. The discal spot of the secondarles is well silvered and margined with pale red.

Early Stages-The larva feeds on the leaves of the huckleberry and willow. Otherwise it is unknown.

Distribution-The species is found in Montana, Colorado, Utah, and British Columbia. Wilsey's collection contains one specimen from Miles City. We have not taken it west of the range.

\section{STRECKER'S SULPHUR.}

Eurymus meadii, Edwards, var elis Strecker. Plate IV and Fig. 37.

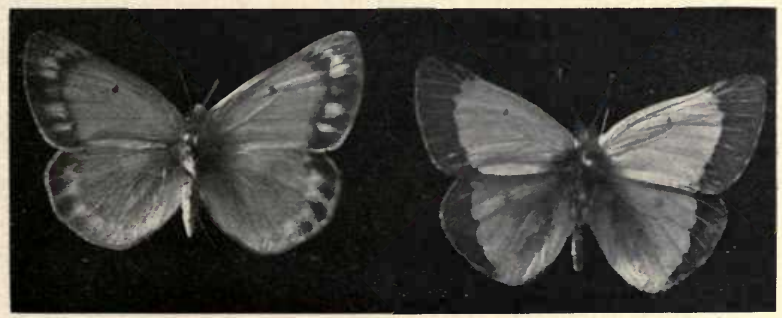

Fig. 37. Eurymus meadii, var. elis, left hand, female; right hand, male.

Butterfly-Expanse of wings 1.85 inches, $48 \mathrm{~mm}$. Male; deep orange red above, with wide black border fringed with red; wing veins in both wings showing through black; black border covering outer third of fore wings, a little less of hind wings; fore wings black at base, extending to hinder angle of wings as a widening wash, ending in black scales over the orange ground; posterior edge of the hind wings with greenish gray 
from 2 to $5 \mathrm{~mm}$. wide, bordered exteriorly by the black border above showing through; discal spots above deeper orange than ground color; below, discal spot on fore wings small, dark brown, on hind wings light silver with red border; legs, antennae, anterior of thorax, hairs of head and fringe deep rose red; sometimes the outer anterior angle of the fore wings and the posterior angle of the hind wings above and below suffused with deep red. Female, similar in general color to male, less pronounced, and if anything, lighter; discal spot on anterior wings black, showing through on under side; discal spot on hind wings similar to male; less black at base of wings, posterior edge of lighter color than in male; black border not so wide as in male, with dashes of much lighter orange than ground color; dashes suffused at anterior angle of hind wing; under side as in male; rose red antennae, thorax, head, legs, and fringe as in male.

Early Stages-Holland says "closely resembling those of meadii, of which it may be only a varietal form.

Distribution-It is recorded as inhabiting the lofty peaks of the Western Cordilleras. It has been taken by Douglass at Fish Creek, August 16, 1900, and in the Tobacco Root Range July 14, 1900.

Remarks-It differs materially from the meadii in the writer's collection taken at Pike's Peak in 1892. Elis as described above from Montana is larger in both sexes than meadii, has much less green, and with decidedly different washings of orange on the borders of the wings of the female. This female meadii has much more red in the ground color than in elis. The meadii were taken at 12,000 feet and elis at about 8,000 which would of course make some difference. We have taken neither meadii nor elis west of the main range. 


\section{Collecting Butterflies at High Altitudes in the Andes.}

While forming these collections I was led to remark the frequency with which closely similar forms recurred at similar altitudes, upon mountains often long distances apart. This was observed in regard to things living in the soil, as well as in respect to winged insects of roving habits. It was not unusual to see butterflies, at closely similar altitudes upon widely separated mountains. This was the case with a Lycaena that has not been described which was taken at $11-12,500$ feet on Pichincha and thirty-six miles away at 12,000 feet on Colocachi, and was not seen elsewhere. But, for the most part, butterflies which were taken at considerable elevations were also found on the connecting, lower ground. Thus Pieris xanthodice, Lucas, though captured so high as 14,000 and 15,000 feet, was found everywhere in the intervening basins; and as, even had this not been so, it would need little effort for them to pass from one mountain to another, and further as they may sometimes suffer involuntary transportation, no particular stress can be laid upon such instances of occasional recurrence at similar elevations.

One Butterfly, however, was exceptional in being found upon nearly all the mountains visited, in numbers, and seemed to be established between the elevations $12,000-16,000$ feet. This is described by Messrs. Goodman \& Salvin, at p. 107 of the Supplementary Appendix, as Colias alticola. It was first obtained near Tortorillas, Chimboraza $(13,000$ feet), and was seen in the Vallon de Carrel as high as 16,000 feet. When we were camped upon Antisana it attracted attention by the great elevation above the level of the sea at which it was flying $(16,000$ feet). It was seen subquently upon all the mountains we visited (except Sara-urcu) between the elevations of $12-15,000$ feet, and was captured at 12,000 feet on Pichincha, on 13,000 feet on Cayambe, and at 15,000 feet on the western side of Chimborazo, and was never either taken or seen in the basins between these mountains.

Whymper in "Travels Amongst the Great An les of t'e Equator." 


\section{Family NYMPHALIDAE.}

\section{The Brush-Footed Butterflies.}
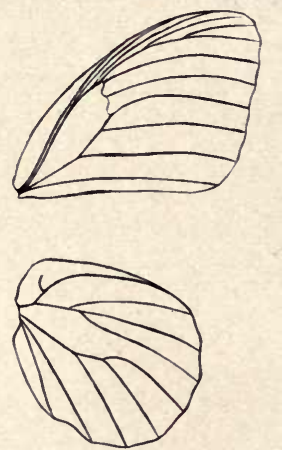

Fig. 38. Venation of Nymphalidae, Argynnis leto.

The family includes chiefly butterflies of medium or large size; but a few of the species are small. With a single exception, these butterflies differ from all others in our fauna, in having the fore legs greatly reduced in size in both sexes. They cannot be used for walking, but are folded on the breast like a tippet.

In the venation of the wings all of the branches of the radius of the fore wings are retained, this vein being five branched. (Fig. 38).

The caterpillars are, in most of the sub-families, provided with horny or fleshy projections. The chrysalids are usually angular, sometimes rounded. They always hang head downwards, supported only by the tail, which is fastened to a button of silk.

Five sub-families are represented in the United States, but three of the five in Montana. The following key will serve to separate them.

\section{FAMILY NYMPHALIDAE.}

Key to Sub-families.

1. With some of the veins greatly swollen at the base

Agapetinae P. 105 with none of the vains of fore wing usually swollen at the base 2 .

2. Antennae clothed with scales, at least above, antennae naked

3. Fore wings at least twice as long as broad Fore wings less than twice as long as broad

4. Papli much longer than thorax

Palpi not as long as the tnorax

Euploeinae. P. 44 Heliconinae

SUBFAMILY EUPLOEINAE.

Butterfly-Large butterflies; head large, antennae inserted on the slummit, naked. The wings are rounded and somewhat elongated. 
Egg-The eggs are ovate, conical, broadly flattened at the base and slightly truncated at the top.

Caterpillar-On emerging from the chrysalis, the head is not larger than the body. The body has a few scattered hairs on each segment. On reaching maturity the head is small, the body large.

Chrysalis-It is re'atively short and thick, rounded, w'th var- few projections.

\section{Key to Genera.}

Palpi remote, not extending much beyond the head; discal cell of hind wings closed; a black spot on vein of hind wings of male. Anosia

Genus ANOSIA, Hubner.

Butterfly-Large seized, fore wings greatly produced at the apex.

Egg-The egg is ovate conical, ribbed with many cross-lines. The eggs are pale green in color.

Caterpillar-Cylindrical, fleshy, transversely wrinkled, with long, slender filaments.

\section{Key to Species.}

Color fulvous; veins black

plexippus

THE MONARCH BUTTERFLY, Anosia plexippus L., Fig. 39.

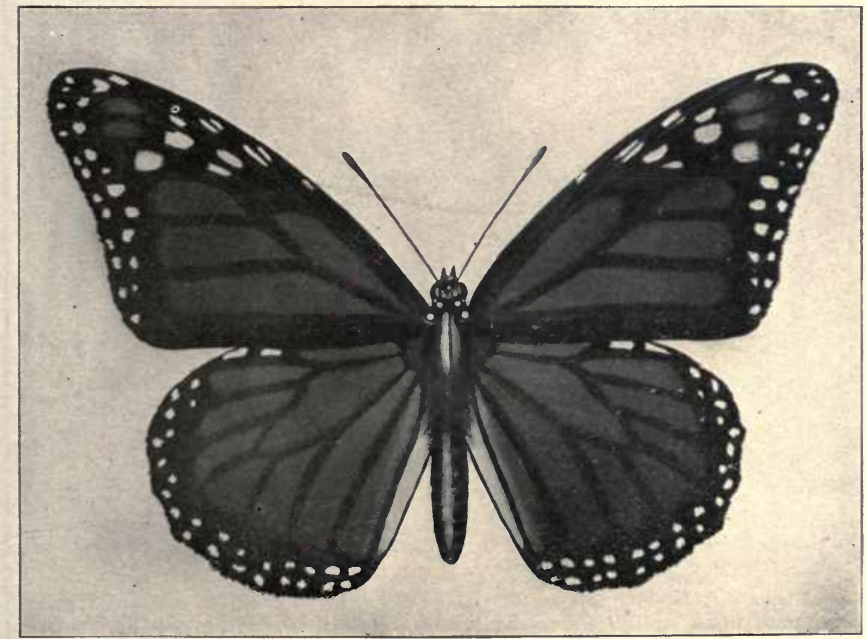

Fig. 39. Anosia plexippus, From water color by Mrs. Edith Ricker.

Butterfly-Expanse of wings 3.75-4.5 in., $96-114 \mathrm{~m} \mathrm{~m}$. Upper surface tawny red or fulvous, with the veins heavily marked with black, a black terminal border containing two rows of white spots, a complete and partial row of white or lighter fulvous spots in a black space beyond the cell of the fore wings. The males have the wings less broadly bor- 
dered with black than the females, and on the first median nervule of the hind wings there is a black scent-pouch. Body black with white spots.

Early Stages-When first deposited the eggs are white, but in two or three days turn yellow, just before hatching change to dull gray. Somewhat conical in form, and marked by twenty-five ribs with the same number of transverse ridges. The young larva is yellowish white, with a large black head. The mature larva is about 1.75 in., $45 \mathrm{~mm}$. long; the head yellowish marked by two triangular black stripes. The body is marked with transverse stripes of black. yellow, and white. It is furnished with black fleshy thread-like appendages.

Chrysalis-About $25 \mathrm{~mm}$. long, pale green, spotted with gold. There are two or more broods in a season.

Distribution-United States generally. The collection of the U. of M. contains specimens from Missoula, the Ruby Mountains, and Miles City. Collected by Coues along the 49th parallel in 1874 . 


\section{The Seasonal Migration of Anosia Plexippus.}

The range of Anosia plexippus is from Patagonia to Hudson Bay. It has not been found in hibernation and, considering its size and conspicuous coloring, it may well be said that it does not pass the winter North of latitude 31 degrees. A careful study of its range, time of appearance, and habits, shows unquestionably that there is a seasonal migration of this very interesting form.

Riley first suggested these movements, when state entomologist of Missouri, in the following words: "There is a southward migration late in the growing season, in congregated masses, and a northward disp - rsion early in the season, through isolated individuals."

The more evident movement is in the fall, when in the Mississippi valley and along the Atlantic Coast, the September air seems to be full of brown butterflies, usually apyarently taking advantage of the cooler winds from the North, though many times bravely beating into the winds with a very strong flight for a butterfly. The Aster patches growing along the roadside and in neglected fields seem to be the favorite places of assembly. At such times a zoology class has no difficulty in providing themselves with material. In fact an active boy with a net can catch them by the hundred in one afternoon.

The collecting together of such numbers was formeriy accounted for by the presence of plenty of food. This alone seems inadequate, sinc 3 many fields, equally inviting, will contain a normal population. It seems likely that a swarm may busy themselves in this way in the fields, awaiting favorable winds. We must pause to consider the probable absence of initiative on the part of the insect. It is more likely influenced by the temperature, the North wind being the cosler, and, for scme reason not explained, awakening in the insec $:$ the dormant instinct of migration.

An instance of the gathering of thousands of Anosia in one tree and the fact that they remained there with occasicnal short excursicns, until a change of wind and temperature, was noted in Bu-lington, Iora, the last week of September, 1905. The fzct that these insects alight on trees in such swarms as to give the $r$ co'or to the tree, $h$ ? $\mathrm{s}$ be $3 n$ cf $i \in n$ recorded. Tnis is not the only evidence of their flocking. There is the best of authority for stories of southward migration. Some have reported clouds so dense as to at times cast a shadow. Dr. Scudder 1 elates a flight on September 2, in New Hampshire, when the southward flight of a swarm was observed by himself. He states that they stretched out in a thin stream that occupied hours in passing. He estimated that in a limited field in front of him, they were passing at the rate of 1,500 per hour. It is little wonder that they are said to fill a tree, bending the twigs to breaking with their weight. Granting that these accounts of large numbers of Anosia in one swarm are exceptional, we can see that spread over this broad land there must be countless millions moving southward every autumn. What advantage, if any, is gained in the association of these insects in swarms, is not easily discerned. 
The fact of Northwara movement in the spring is not so easily established. As before stated the Anosia is not reported to have been found North of latitude 31 degrees in the winter. When Spring opens neither the egg, pupa or adult is to be found. The milkweed is a foot high in Iowa and much good fodder is awaiting the larvae, before the adult makes its appearance, and lays eggs on the tender unfolding leaves near the tip of the growing plant. Some say that the appearance is not that of a tattered "left over," as is usually the case with hibernating species. They appear as a whole to be a fresher and newer lot; though I have seen some that looked a good deal the worse for wear rather early in the season. There seems little doubt, however, that the new arrivals have not hatched in our region, since there has been no opportunity for larvae to develop and pupate. It seems more probable that they are the spring brood from an earlier season in the south. We must not, however, conluse them wlch those that disappeared in that direction last fall.

In Southern Iowa it seems probable that the eggs laid by the first arrivals produce a new brood in July. These in turn produce the brood that soon after arriving at maturity southward. We seem to have two broods; while New England and northern climes have one only, and that one, from the eggs of the first brood hatched in our latitude. The northward migration is continued to Hudson Bay and north of the range of the food plant of the larvae; a significant fact, in itself, proving the migration of the species. T'he northern boundary of the food plant limits the adult of other species sharply. This is noticeably the case with Papilio ajax in southern Iowa, where a species very abundant south of us is limited by the food plant, the Pawpaw, which disappears near the 40th parallel.

There are several known peculiarities of this insect that especially fit it for this sort of a life. The well known immunity from molestation by insectivorous birds, the comparatively long intervals between oviposition, enable a butterfly of this species to scatter its progeny over a great territory, since but one egg is laid in a place. The slow northward movement of the season in spring allows time for additional broods further South. The adults that first arrive here in the spring are supposed to be from larvae grown several hundred miles to the southward, where there may be four or more broods in one season. This northward movement may therefore be considered a sort of a relay race. The returning hosts contain none of the brood that came northward, since the life of an insect after final oviposition is usually short and its excuse for existence has expired.

Granting that the seasonal migration of this butterfly is established, we may say that this is merely another way in which nature replenishes the earth after the life destroying frosts of winter, so fatal to insect life. Hibernation has its advantages, and does not call for so complex an adaptation. Why Anosia has this different means of preservation is as much a puzzle as ever. This illustrates anew a striking observation by Mr. Frank Springer, the paleontologist, when sepaking of the marvelous perfection to which an organism may be brought through a period of development, only to be apparently discarded and the whole problem worked out in an entirely different way in succeeding forms. $\mathrm{He}$ says 
that "it seems as though Nature delights to show in how many different ways the same result can be accomplished." In this case, it seems as though the combination of the striking adaptations of Anosia have made it second only to the Pieris rapae, or "cabbage butterfly", in numbers and distribution over the earth.

In recent times this insect has spread to Australia, and from there to all the East Indies and the Philippines. It is captured in Europe with increasing frequency, and will doubtless be as successful in the old world as in the new. It is a harmless species and will not prove as unwelcome as has the little white pest in this country. We may wish it success in its efforts to colonize the East, and fear no reports of misbehavior to discredit the benefits to be derived from New World expansion. As a rule we have given them few plants and animals that have merited their disapproval. The Phylloxera is a notable exception, since it threatens the vinyards of the Old World. On the other hand yuu can hardly name a weed or obnoxious animal in this hemisphere that nas not been imported to our country. At all events the behavior of Anusia will be watched in the Old World with a growing interest to see if it will there develop any new and interesting traits.

MAURICE RICKER.

Burlington, Iowa, September, 1905. 


\section{SUBFAMILY NYMPHALINAE. \\ The Nymphs.}

Butteryfly-The butterflies of this subfamily are mainly of moderate or large size, though some of the genera contain quite small species. The antennae are always more or less heavily clothed with scales, and are usually as long as the abdomen, and in a few cases even longer.

It is impossible to briefly describe these butterflies because they vary so much. It is the largest of the subfamilies.

\section{Key to Genera.}

1. Palpi nearly connivent, porrect

2. Eyes naked 3 .

Eyes hairy 13.

3. Club of antennae short, ovoid, usually flattened in dry specimens 4 .

Club of antennae obconic or generally terminating in a knob. 12.

4. Outer margin of fore wings sinnous.

4a. Upper surface with eye spots,

Euptoieta, P. 51

Upper surface without eye spots,

Speyeria, P. 52

Outer margin of fore wings not sinnous

5. Large or medium size; cell in secondaries closed or open

Small cell in secondaries open

6. Color of both wings fulvous, with silver spots

Fore wings fulvous, hind wings black

Semnopsyche.

Color of both wings fulvous, without silver spots

7. Two innermost sub-costal nervules arise before or at the end of the cell

8. Branch to the median vein of the front wings

Argynnis, P. 54

No branch to the median vein of the front wings

9. Only one sub-costal nervule vein arises before or at the end of the cell

10. General color fulvous or black

Brenthis, P. 69

General color tulvous, with a prominent black border; no silver spots on the under side

i1. Under side of hind wings brownish or brownish yellow

Phyciodes, P. 78

12. Hind wings not tailed; ground color black, fulvous or mahogany brown

Basilarchia, P. 102

13. A golden or silver spot on under side of hind wings Polygonia, P. 84 No golden or silver spot on under side of hind wings

14. Apex of fore wings somewhat truncate, the angles rounded

Vanessa, P. 98

Apex of fore wings distinctly truncate, the angles sharp

15. Ground color deep fulvous or brown; black bar across the cell of fore wing; black border or submarginal band

Eugonia, P. 90 Ground color maroon brown, out margin yellow, supplemented by a row of blue spots

Ground color brown, submarginal band fulvous

Euvanessa, P. 96

Aglais, P. 97 
THE VARIEGATED FRITILLARY, Euptoieta claudia, Cramer. Fig. 40.

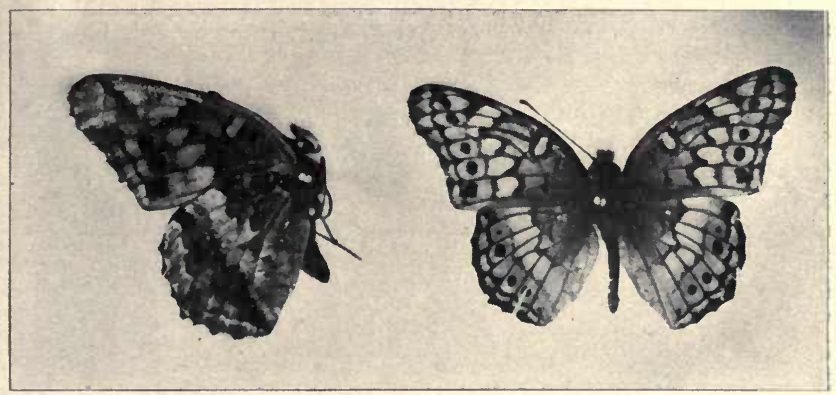

Fig. 40. Euptoieta claudia, from Miles City, showing upper and lower surfaces.

Butterfly-Expanse of wings from 1.75 to 2.75 inches, $45-70 \mathrm{~mm}$. Upper side of both wings fulvous or dull ferruginous, darker toward the base, crossed by an irregular black median line, which is darker, broader, and more zlgzag on the fore wing than on the hind wing. This line is followed outwardly on both wings by a pair of more or less blackish spots. The outer'margin is black, fringes pale fulvous, checkered with black at the end of each nervule. At the end of the cell in the fore wing there are two black lines inclosing paler fulvous spots, and both wings near the base have some curved black lines.

Under side of fore wings fulvous to the zigzag line, with discal pale spot. The outer half of the wing is pale, with a little submarginal reddish wash below the apex, and a large gray triangle on the costa. A brown spot near the posterior angle sends a marginal streak toward the apex.

The hind wings are pale brown in the basal half, streaked with white along the veins, and with transverse striae of darker brown. Beyond the middle they are whitish, shading off into the same brown as the base, with more or less whitish along the margin, the anal portion of the outer half being nearly as dark as the base, while the costal portion is almost. white. There are about three indistinct marginal ocelli.

Early Stages-The egg is conoldal, depressed at top, flat at base marked by about twenty longitudinal ribs, half of which reach the summit. Mature larva is 1.2 inches, $28 \mathrm{~mm}$., cylindrical, of an orange ochre color, smooth, striped longitudinally with black, which is almost concealed by the white spots that cover it. The chysalis is .8 inch, $21 \mathrm{~mm}$. long, pearl white, Irridescent, marked with dark brown patches and points. On the abdomen there are four rows of conical tubercles. There are two or three broods during a season, the last one probably hibernating in the larval state. It feeds on violet, passion flower, mandrake, Sedum, Desmodium, and Portulaca. 
Distribution-The species has been taken as far north as Long Island and Connecticut, though it is a rare visitor in New England; it is quite common in Virginia and thence southward, and occurs not infrequently in southern Illinois and Indiana, ranging westward and southward over the entire continent to the Isthmus of Panama, and thence extending over the South American Continent, wherever favorable conditions occur.

In Montana it has been taken by Cooley at Forsyth and in Gsllatin County, and by Wiley at Miles City. At the latter place it is common, but averaging smaller in size. The species seems to be confined to the Great Plains region of the state, although later collections may show it farther west than it seems from present records to be.

THE REGAL FRITILLARY.

Speyeria idalia, Drury. Fig. 41.

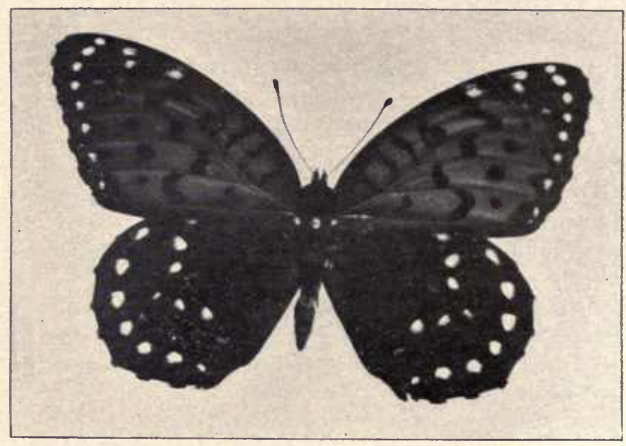

Fig. 11. Speyeria idalia, Drury.

Butterfly-Expanse of wings from $2.75-3.6$ inches, $70-90 \mathrm{~mm}$.

Male. Upper surface of fore wings fulvous, black along the costa, with a black outer border which is a little wider than the costal border; base and hind margin brown; three black bars in cell, another bar at the end with an open $\mathbf{S}$ united to it enclosing a fulvous spot; beyond the cell runs a transverse zigzag line, a submarginal row of black dots, and next the border a row of black crescents. Hind wings black, with violet reflections; base of wings washed with fulvous; a black spot in cell, an irregular row of yellowish spots beyond cell, and a marginal row of fulvous spots; fringes alternate spots of black and white. Under side of fore wings fulvous, white along the costa, a marginal row of silver spots enclosed in black crescents, and some silver on the costa near the apex; black of upper side repeated; under side of hind wings yellowish brown, with twenty-nine silver spots and patches, besides some silver shading.

Female differs from male in being larger, with broader terminal band, which contains a row of white spots, with six or more white spots near the apex, the outer row of spots on the hind wings of same color as the inner. 
Early Stages-Egg conoidal, truncated, rounded at base, marked vertically with eighteen ribs. Larva hatches in about twenty-five days. Larva at maturity 1.75 in., $45 \mathrm{~mm}$., long, velvety black, banded and striped with ochre yellow changlng to dull orange or red, and furnished with six rows of fleshy spines, each with several black bristles; head red above and black beneath. Chysalis an inch long, brown and yellow on abdomen, remainder pinkish brown or brown. The larva feeds on violets.

Geographical Distribution-Wiley has collected it at Miles City. It is not reported from other places, and the Wiley collection has but a single specimen. It is reported as common from Maine to Nebraska. It is to be expected the species would be found in the eastern end of the state. In the eastern states it is rather local, and frequents open spots on the borders of woodlands. At times it is apparently common, and then for a succession of seasons is scarce. It flies from the end of June to the beginning of September. 


\section{THE FRITILLARIES, THE SILVER SPOTS, THE ARGYNNIDS.}

\section{Genus Argynnis. Key to Species.}

1. Under side of wings with silver spots

Under side of wings without silver spots

2. Basal half of wings fulvous brown, strong colored sub-marginal band

Less than half the wings brown

3. Under side of hind wings with a light sub-marginal band

Under side of hind wings without a light sub-marginal band 4 .

4. Under side hind wings brown aphrodite, P. 57

Under side hind wings olive green

5. Under side of hind wings light brown

Under side hind wings maroon

aphrodite, P. 57

Under side apex fore wings buff, base pale cinnamon red

atlantis, P. 63

Under side hind wings apex buff, mottled with green

electa, P. 63

eurynome, P. 64

Under side hind wings basal two-thirds reddish brown, size large, cybele, P. 54

Under side hind wings deeply ferruginous

bremneri, P. 62

Under side hind wings dark reddish brown

rhodope, P. 62

6. Under side of hind wings ferruginous

Under side of hind wings greenish

7. Spots yellowish white

8. Spots dull green,

Spots dull green, dark at outer edge,

9. Under side hind wings olige green

Ground color green, spots large

Ground color yellow and buff

hesperis, P. 61

eurynome, var. artonis, P. 65 eurynome, var. clio, P. 65 .

edwardsii, P. 59 nevadensis, P. 60

\section{THE GREAT SPANGLED FRITILLARY.}

\section{Argynnis cybele, Fabricius, Fig. 42.}

Butterfly-The expanse of wings of specimens in the eastern states is from 3 to 4 inches, or 76 to $102 \mathrm{~mm}$. Upper surface fulvous or yellowish brown, more yellowish in the male than in the female. In the cell of the fore wings five black bars, except in the fourth bent outward in the lower half, the two outer united above. Beyond the cell are the usual zigzag black line and the subterminal row of dots, the middle ones of the fore wings the largest. Just within the outer margin is a termnial narrow line, and within this, and on the fore wings with their points resting on this line, is a row of crescents; the fore wings edged with the same color. The cell of the hind wing with three more or less distinct bars.

Under side of fore wings pale yellowish brown, the apical space yellowish and enclosing a bright brown costal patch; the lines and dots the same as above, but near the apex more brown. The apical five or six of the spaces enclosed within the submarginal crescents are wholly or partly silver, with three silver patches within this line. 
The hind wings have the basal two-thirds reddish brown more or less mottled with yellow, the outer boundary of this color a row of seven silver spots. Outer margin brown, fading into yellow at the anal angle, and within this another row of seven large silver spots rounded within and edged with brown. Between these two rows is a bright yellow band without spots.

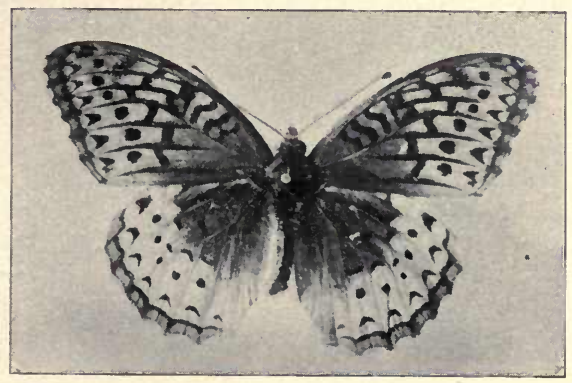

Fig. 42. Argynnis cybele.

Early Stages-The egg is short, conoidal, ribbed like those of other species, and honey-yellow. The larva in mature state is 1.8 to 2 inches

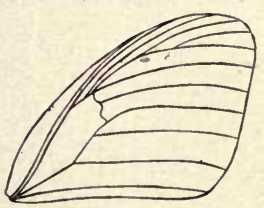
long, velvety black, chocolate-brown underneath. The body has six rows of slender black spines, generally ornamented with orange red at the base, and beset with many short black bristles. The caterpillar is nocturnal, and feeds on violets. It hibernates immediately on hatching from the egg, feeding to maturity the following spring. The chrysalis is dark brown, mottled with reddish brown or slaty grey.

Distribution-It is from the Atlantic west-

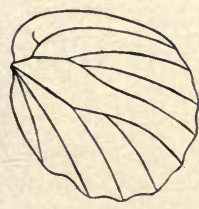

Fig. 43. Venation of Argynnis leto. ward to Nebraska. Barber, 1894, reports it from the northwestern part of Nebraska. It has been taken at Edmonton, B. C., where it was found flying with A. lais by Captain Gamble Geddes, in 1883. A single specimen is in the Wiley collection from Miles City. taken June, 1900. It is a trifle less than three inches expanse, and placed side by side with specimens from Michigan, Ohio, and Illinois is indistinguishable from them. It has been taken at no other place in the state, and only the one specimen has been taken at the present writing. 
THE LETO BUTTERFLY.

Argynnis leto, Edwards. Figs. 38, 43, 44, 45.

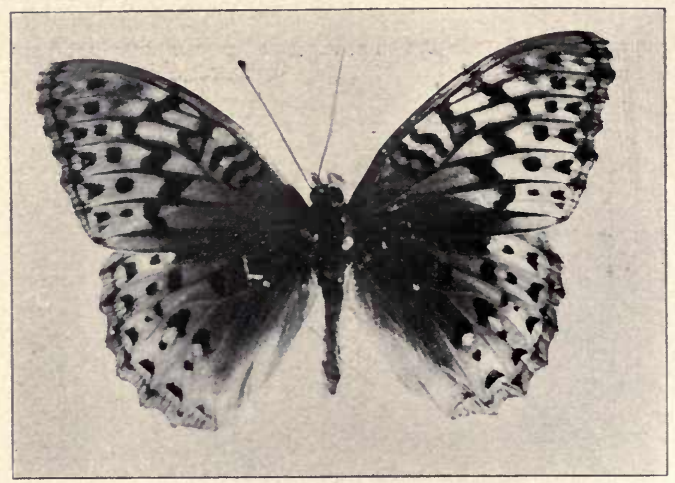

Fig. 44. Argynnis leto, male.

Butterfly-The male on the upper side is a dull fulvous with the characteristic black markings of the genus; the basal area is darker. The under side of the fore wings is plae fulvous upon which the markings of the upper side reappear. Both wings on the under side, are shaded with brown toward the base; the hind wings are traversed by a sub-marginal band of light straw yellow. The female is marked as the male, but the general color is pale straw yellow, and all the darker markings are deep blackish brown, those at the base of both wings being broad and running into one another, so that the inner half of the wings appear to be broadly brownish black. On the under side it is also marked the same as the male, but with the dark portions blacker and the lighter portions pale yellow. The marginal row of light spots on the hind wings appears on the under side as silver crescents; there are three rows of silver spots on the brown part of the wing. Expanse 2.50 to 3.25 inches, 64 to $83 \mathrm{~mm}$.

Early Stages-Unknown.

Distribution-It occurs in California, Oregon and Montana. In Montana it is found on both sides of the mountains. In the western part it is abundant about Flathead lake. It is a beautiful insect, demanding the attention of the collector, frequenting the more open woods, skirting the bushes by the roadsides, or frequenting the sunny open places in the woods. It has been taken, in addition to that mentioned, at Mount Lolo, Missoula, the Mission Mountains, and the Yellowstone Park by Elrod, at New Chicago by Douglass, at Helena by Brandegee, and at Miles City by Elrod. A male was collected at Miles City in July,.1893, and a female in Yellowstone Park in September, 1894, both identified by Edwards. It is likely to be found in most parts of the state, and will ornnament any 
collection. Allen reports a female nokomis from Dillon. I have not seen the specimen, but think it may be leto.

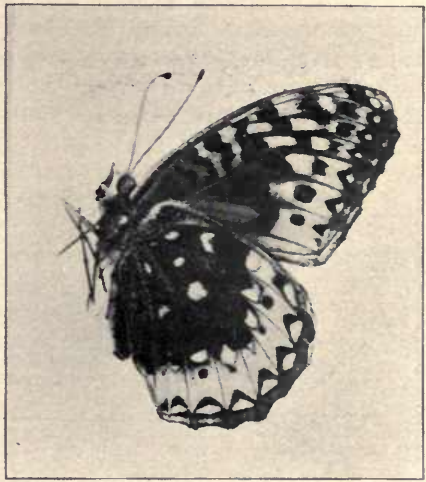

Fig. 45. Argynnis leto, female.

THE APHRODITE FRITILLARY.

Argynnis aphrodite, Fabricius. Figs. 46, 47.

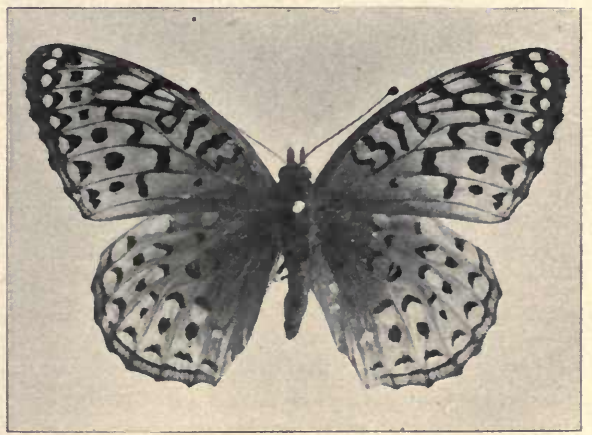

Fig. 46. Argynnis aphrodite, var alcestis, upper side.

Butterfly-Expanse 2.25 to 3 inches, $57-76 \mathrm{~mm}$. Upper surface of wings bright reddish fulvous; the basal third of both wings washed with cinnamon brown. The black markings similar to cybele and leto. The median zigzag line is often broken. The two lines at the outer margin of the female are more or less blended, and the two are present on the hind wings of both sexes. The under side of the fore wings is pale reddish fulvous, the apical portion and along the costa buff, with pale brown markings; six marginal and three sub-marginal-silver spots. The 
hind wings are cinnamon brown with a narrow sub-marginal band. The silver spots are more or less edged with black.

Early Stages-The eggs are short, conoidal, honey yellow and ribbed. The caterpillar has a velvety black spot at the base of each spine, the chrysalis has the tubercles on the back short, and the basal segments are partly colored. The caterpillar feeds on violets.

Distribution-It is found in the northern and middle western states. Taken in the state by Wiley at Miles City, and by Elrod at Missoula. Cooley has one specimen from near Bozeman at 4,200 feet, July 20. Coubeaux reports it common in Bear Paw Mountains.

Var. alcestis, Edwards, Fig. 47, the Ruddy Silver-spot is very much like aphrodite, but distinguished from it by the fact that the hind wings are uniformly dark cinnamon brown, without any band of buff on the outer margin. It is of the same expanse as aphrodite. It is said to largely replace aphrodite in the western states. Indeed, there is likely to be difficulty in separating alcestis from the true form of aphrodite.

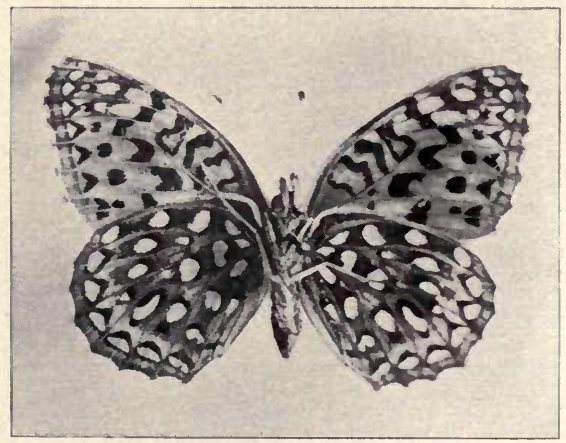

Fig. 47. Argynnis aphrodite, var. alcestis, lower side.

Alcestis has been taken by Elrod at Missoula and Flathead Lake, by Douglass in the Madison valley. The latter closely resemble aphrodite from Miles City. By far the greater number of specimens examined are aphrodite, and not var, alcestis. 


\section{EDWARDS FRITILLARY.}

Argynnis edwardsii Reakirt, Fig. 48.

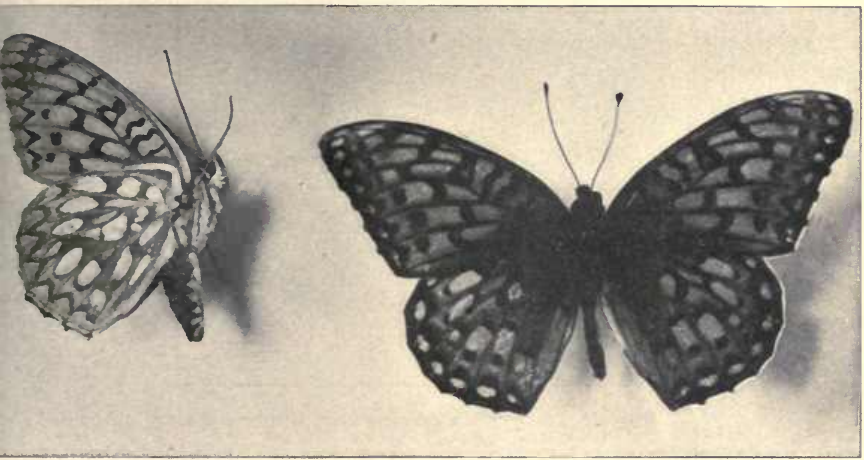

Fig. 48. Argynnis edwardsii, upper and lower surfaces.

Butterfly-Expanse of wings 2.30-3.00 inches, 55-75 $\mathrm{mm}$. Ground color pale fulvous, but little obscured with fuscous at base; a heavy black border at base; at least heavier than in nevadensis; lighter buff than nevadensis, under side of hind wings with large silver spots, olive brown color; the olivaceous of the wings encroaches on the marginal band. It may be known by its large size, by the long and pointed fore wings, and by the great size of the silver spots that ornament its under side.

Distribution-According to Holland the species is not uncommon in Montana and Colorado. In Montana it has been taken by Wiley at Miles City, Douglass at New Chicago, and Fish Creek. Collected by Coues in 1874 on Chief Mountain.

Remarks-Attention was called in the introduction to specimens identified by Edwards. One specimen sent by Wiley and another by Elrod from Miles City in different years were identified respectively as nevadensis and edwardsii. When placed side by side they are indistinguishable either in size or markings. Larger specimens from low elevation are likely to be called edwardsii, smaller ones from higher elevation nevadensis. We believe that experiments in breeding will show the two species to be one. 
THE NEVADA FRITILLARY.

Argynnis nevadensis, Edwards, Figs. 49, 50.

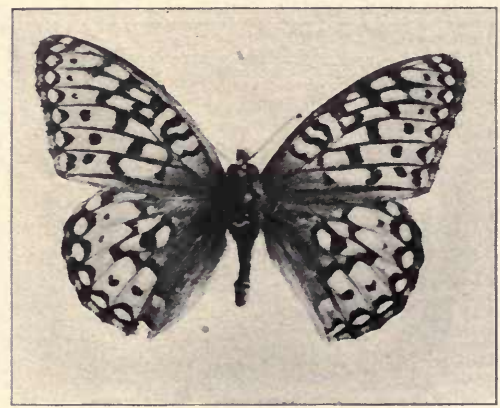

Fig. 49. Argynnis nevadensis, upper side.

Butterfly-Expanse of wings, male, 2.50-3.00 inches, 63-75 mm.; female, $3.00-3.50$ inches, $75-88 \mathrm{~mm}$.

The ground color is pale fulvous, but little obscured with fuscous at the base. The outer margins are heavily bordered with black. The dark markings of the discal area are not heavy. The fore wings on the under side are pale buff, the spots well slivered; the hind wings are greenish; the belt is narrow and clear, and the spots are large and well slivered. The female is much like the male, but larger and paler. The outer margin of the fore wings in the female are more heavily marked with black and marginal spots are light buff in color.

"It is allied to Edwardsii in shape, and forms a sub-group with it. It is brighter colored, smaller sized, and beneath the ground color is yellow and buff, mottled in the male with pale olive-green, and in the female with darker buff" (Edwards).

Distribution-This species is found in the Rocky Mountains of Utah, Nevada, Montana, and British America. Specimens have been taken from Tobacco Root range by Douglass; Missoula by Elrod; Swan Range, 7,600 feet, by Elrod; Lolo Hot Springs by Elrod; Mount Ascension near Helena, by Brandegee; Shields river, 9,000 feet, Gallatin Valley, East Flathead, Park county, by Cooley. It thus ranges from 3,200 feet to 9,000 feet altitude. Collected by Coues in 1874 at Three Buttes, August 8 


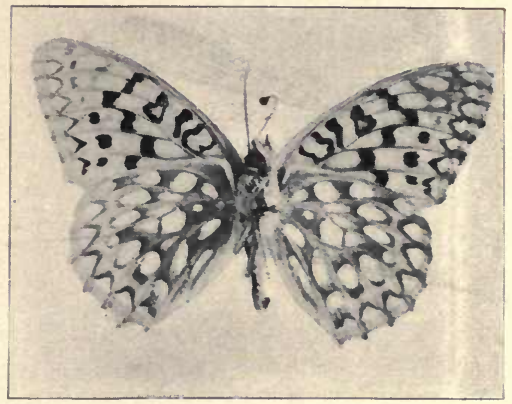

Fig. 50. Argynnis nevadensis, lower side.

THE HESPERIS FRITILLARY.

Argynnis hesperis, Edwards. Fig. 5 7.
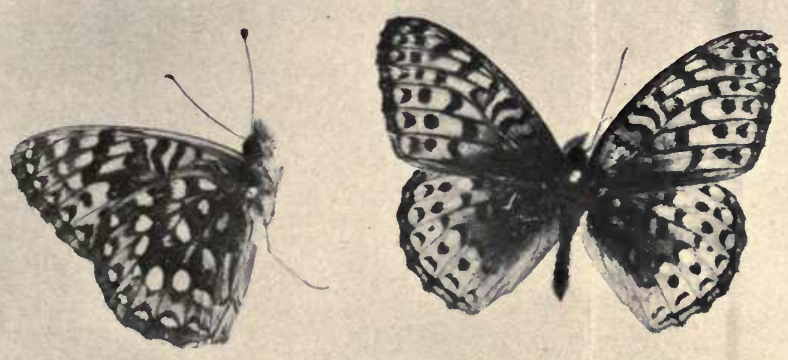

5.g. 51. Argynnis hesperis, upper and lower surfaces.

Butterfly-The male on the upper side of the wings is fulvous, shaded with dark fuscous for a short distance from the base. The black spots of the median band are rather broad, and seem to coalesce through dark markings along the nervules. The under side of the fore wings is pale ferruginous, tinged with a little buff at the tips. The under side of the hind wing is dark ferruginous with a narrow buff sub-marginal band. Ground color of the female is paler than the male. In neither are the light spots marked with silver; they are opaque, yellowish white. Expanse, 2.25-2.40 inches, $57-61 \mathrm{~mm}$.

Early Stages-The life history remains to be learned.

Distribution-The butterfly is found among the mountains of Colorado and Montana. 
It has been taken by Elrod in the National Park, at Missoula, in the Swan Range, and on Mount Lolo near Missoula. Cooley has a specimen from Bozeman at 4,800 feet. Brandegee collected it near Helena, and Barnes at Aldridge. Rare in the Bear Paw Mountains, according to Coubeaux.

THE RHODOPE SILVER-SPOT, Argynnis rhodope, Edwards.

Butterfly-Expanse, male, 2.20 inches, $55 \mathrm{~mm}$; female, 2.40 inches, $60 \mathrm{~mm}$. The upper side of the male is bright fulvous, both wings on the inner half heavily clouded with dark fuscous. The black markings are very heavy and confluent. The outer border is solid black. very slightly, if at all, interrupted by a narrow marginal brown line, in this respect resembling atlantis. On the under side the fore wings are dark ferruginous, on the outer margin rich dark brown. Between the spots at the end of the cell and the nervules below the apex are some clear, bright straw-yellow spots. The upper spots of the marginal series are silvered. The hind wings are dark reddish-brown, very slightly paler on the line of the marginal band. The spots are pale straw-yellow, except those of the marginal series, which are distinctly silvered. The female on the upper side is of a lighter and brighter red, with the markings dark and heavy as in the male sex. On the under side the markings in the female do not differ from those in the male, except that the primaries on the inner half and at the base are bright pinkish-red (Holland).

Early Stages-Unknown.

Distribution-The insect flies in British Columbia. Coues collected a single female August 8, 1874, near Three Buttes, Montana. This is the only record of its capture in the state.

BREMNER'S SILVER-SPOT.

Argynnis bremneri, Edwards. Fig. 52.

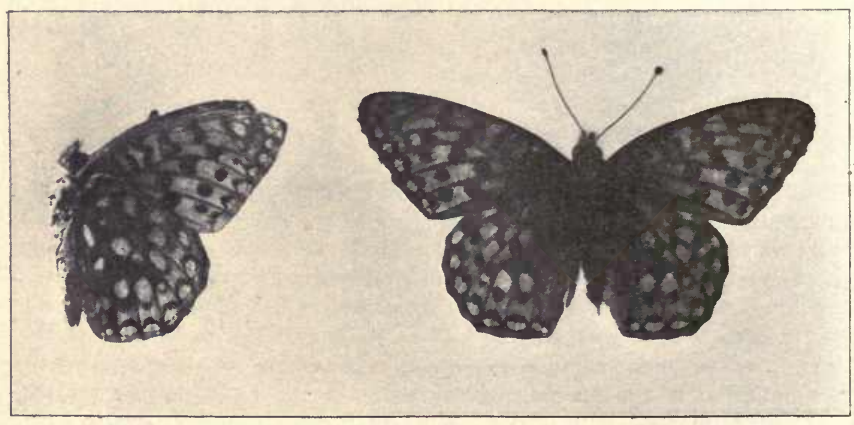

Fig. 52. Argynnis bremneri.

Butterfly-Expanse, 2.4 to 2.7 inches, 60 to $70 \mathrm{~mm}$. The male on the upper side is bright fulvous. The black markings, especially those about the middle of the wings, are heavy. Both wings at, the base are 
clouded with fuscous, the under side of a primaries red toward the base, buff on the apical area; the sub-apical and the upper marginal spots well silvered; the hind wings with the inner two-thirds more or less deeply ferruginous, a little mottled with buff, very rarely encroached upon by the dark color of the inner area, except occasionally near the angle (Holland).

Early Stages-Undescribed.

Distribution-Found in Oregon, Washington, Montana, southern portions of British Columbia and VanCouver's Island. Specimens in the University of Montana collection from Flathead lake by Elrod, and from Tobacco Root Mountains by Douglass. The specimens show the under side of lighter color than from Vancouver, but with the characteristic heavy black markings.

\section{THE ELECTA SILVER-SPOT.}

Argynnis electa, Edwards.

Butterfly-Expanse, 2.00 to 2.25 inches, 51 to $64 \mathrm{~mm}$. The male is dull-reddish fulvous on the upper side. The black markings are narrow. The base of both wings is slightly obscured. On the under side the fore wings are pale cinnamon-red, mottled on the disk with a little buff. The sub-marginal band is buff, quite narrow, and often invaded by the ground color of the inner area. The silvery spots are usually very well marked and distinct, though in a few instances the silvery color is somewhat obscured. The female has the black markings a little heavier than the male; otherwise there is but little difference in the sexes (Holland).

\section{Early Stages-Unknown.}

Distribution-Among the mountains of Montana and Colorado. Holland says it is often confounded with atlantis, but is wholly distinct, smaller in size, the fore wings relatively broader, and the markings not so dark on the upper surface. We have not taken it.

\section{THE MOUNTAIN SILVER-SPOT.}

Argynnis atlantis, Edwards. Fig. 53.

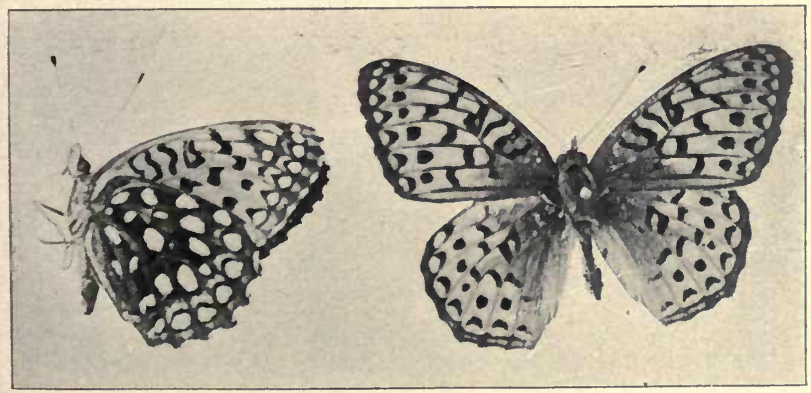

Fig. 53. Argynnis atlantis, upper and lower surfaces. 
Butterfly-Expanse of wings, 2.25-2.50 inches, 55-65 $\mathrm{mm}$. Upper surface fulvous, obscured by brown scales on the fore wings from the second bar in the cell obliquely to below the median zigzag line on the hind margin; the two marginal lines so blended that not much of the ground color is left. Marks as in A. aphrodite. Under side of fore wings reddish fulvous, costa and apex light buff, the apical patch and outer margin brown, with the apical silver spots, six marginal, three sub-marginal; hind wings dark red brown, much mottled with greenish gray or drab, the sub-marginal band pale yellow, usually pure from margin to margin. Silver spots as in aphrodite.

This insect resembles aphrodite; it is distinguished from that species by its smaller size, its somewhat narrower wings, the deeper color of the base of the wings on the upper side and their darker color on the under side. The sub-marginal band is pale yellow, narrow, but distinct and always present.

Early Stages-The egg is conoldal, with twelve to fourteen ribs, honey yellow. The caterpillars are hatched in the fall and hibernate without feeding until the following spring.

Caterpillar-The head is dark blackish brown. The body is velvetypurple above, a little paler on the underside. The usual spines occur on the body, and are black, grayish at the base. The larva feeds on violets.

Crysalis-Light brown, speckled, except on the abdominal segments, with black.

Distribution-The species has a wide distribution. It ranges from Maine to the mountains of western Pennsylvania, thence southward along the central ridge of the Alleghanies into West Virginia. It is found in Canada, extending westward into the Rocky Mountains.

In the state it has been taken at Missoula, Mount Lolo, and Flathead Lake by Elrod, and at Bozeman by Cooley. It does not seem to be represented .n Wiley's collecılons. According to Coubeaux it is common in the Bear Paw Mountains.

THE EURYNOME FRITILLARY. Argynnis Eurynome, Edwaròs. Fig. 54.

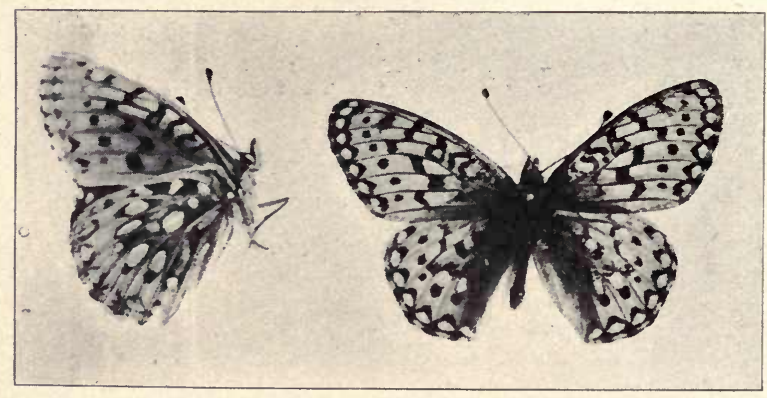

Fig. 54. Argynnis eurynome. 
Butterfly-Expanse, male, 1.70-2.00 Inches, 45-50 mm.; female, 2.00 inches, $50 \mathrm{~mm}$. The wings on the upper side of the male are bright yellowish fulvous, but little obscured at the base. The outer margins are edged by two fine lines which are occasionally confluent. The under side of the fore wings is pale buff, laved with cinnamon brown at the base and along the nervules; the spots on the margin and in the apical area are well silvered. The hind wings on the under side are buff, with "the basal and discal areas mottled with pale brown or pale olive-green. The marginal belt is broad and clear buff; all the spots are well silvered.

The female is like the male, but paler, with the dark markings, especially those of the margin, heavier; the marginal spots inclosed by the lunules are much paler than the ground-color, and in many specimens almost white. On the under side the wings in this sex are like those of the male, but the fore wings are more heavily laved with clannamonbrown at the base.

Early Stages-The egg has been figured by Edwards, otherwise we must say unknown.

Distribution-Common in Colorado, Montana, and British America, showing much variation. Dyar calls erinna, bischoffi, artonis, clio, arge and cunninghami varieties of the species. Eurynome has been taken in the state by Cooley at Bozeman, 4,800 feet, and 9,500 feet; by Elrod in the Swan Range at 6,500 feet, Flathead at 3,000 feet, and Mount Lolo; by Douglass in the Tobacco Root Mountains 8,000 feet, Madison valley, Ruby Mountains; by Brandegee on Mount Ascension and near Helena, and by Barnes at Aldrich. Coubeaux says it is rather common in the Bear Paw Mountains. Allen has collected it at Dillon.

Var. Clio, the Clio Fritillary. The spots on the underside are without silver. Otherwise like the type.

Taken by Cooley in Gallatin County at 6,800 feet elevation, and at Shields river at 6,700 feet. A specimen with very little silver was taken by Eirod in the Swan range at 6,700. A female taken by Dr. Coues at Chief Mountain August 21, 1874.

Holland says "The female very closely resembles the female of artonis, and in fact I am unable to distinguish the types of the two species by any marks which seem to be satisfactory."

Var. bischoffi, Bischoff's Fritillary, is like the type, but the upper side is heavily obscured by black, concealing the basal wing markings. The female has the spots within the lunules pale and almost white. It is a boreal form.

Taken by Cooley. Three specimens, one from Shields river, 6,700 feet, two from Gallatin county, one at 8,300 and one at 9,400 feet.

Var. artonis, the Artonis Fritillary, may be distinguished "by the entire absence of silvery scales upon the under side of the hind wings, and also by the fact that the silver spots on the under side of the hind wings are not compressed and elongated as much as eurynome, and by the further fact that all the dark marginal markings of the under side are obliterated. In the female the dark markings underneath are heavier. It has been found in Colorado, Nevada, Utah and Arizona. We have one specimen from the Yellowstone Park. 


\section{Butterflies at Miles City, Montana.}

A barren country surrounds Miles City, the center of the great grazing territory of eastern Montana, a country of prairie and badlands with little verdure other than that on the immediate border of the rivers and in the creek bottoms.

Here a lover of groves and forests must be content with a variety of trees that might easily be enumerated on his ten fingers, and but few of even these.

Cottonwoods, broken and scrawny, are the only trees of large size near the city, but as one penetrates the country to the heads of the Yellowstone's many tributaries, he meets with ash, elm, box-elder and willows, all native varieties, and differing somewhat from the same trees of the eastern states.

In the badlands and in the hilly sections are pines and cedars also, but the majority of our country is a vast prairie, grass clothed, but bare of tree or shrub (the ever-present sage-brush excepted) and parched by the sun from July until winter.

What limited amount of shrubbery does occur is also confined to the water-courses. We have our native choke-cherry, wild rose, plum, willow, snowberry, buffaloberry, greasewood and sagebrush, a meagre list indeed, when compared to the hundreds of shrubs and brushes abounding in most eastern localities. All vegetation without it may be grasses, and wild flowers occur with us, but in the most limited variety. We have no woods, no swamps, no hedges. What wonder then that the entomologist's hopes are saddened as he realizes that a corresponding dearth exists among his favored and busy tribes.

I wonder who can recount the exact number of Papilios he has seen during three years past? It is my good (?) fortune to have seen just fourteen during that period. In the season of $1891 \mathrm{I}$ saw but one, it was one of the Turnus group, probably rutulus or daunus, its rapid flight however, baffled detection. In May of this year while returning from our ranch, on horseback, a distance of about one hundred miles, I saw another of this same group, but was unable to capture it. During this trip, also, I counted nine zolicoan, only one of which was not in rapid flight across country; this one, a female, was depositing her eggs on our native wild parsnips, and I caught her easily, and obtained some twenty eggs, which I reared on cultivated parsnips in my garden. The only other Papilio seen this year was one related to zolicaon, but had none of the prominent show of yellow so characteristic of that species when on the wing. What it may have been I cannot say.

Finally, two specimens of zolicaon taken on the summit of Signal Butte, near this city, on May 30, 1892, complete the number. I cite my experience with the Papilios to give a general idea of the scarcity of species occurring here. 
A few species of Colias, Pieris, Euptoieta, Phyciodes, and Lycaena occur here, however in sufficient abundance not to be called rare. There exists an unusually localized distribution among most species here, which doubtless results from a similar localization of the foodplants, many of which are to be found only near flowing springs or other sources of moisture. The Satyrids, Pamphila, and other prairie varieties, however, may be met with in country of almost any character, as also may such species as the Argynnids, Pyrameis cardui or Danias archippus.

This season has proven an unusually productive one, and fully twice the number of butterflies were on the wing this year than appeared in either 1891 or 1892 .

Our climate and soil are so dry that no agriculture is successful without irrigation, and I attribute this season's productiveness in the Lepidoptera of this immediate vicinity to systems of artificial irrigation, which has been successfully operated here only the last two seasons, and no doubt all insect life so dependent upon vegetation, will steadily increase as the amount and variety of plant-life is multiplied year by year by the introduction of agriculture under our irrigation systems along the Tongue and Yellowstone River bottoms.

In the interest of the readers of the Entomologist News I append a list of the species of diurnals that I have taken about Miles City during a three years' residence here:

Papilio zolicaon, rare.

Pieris rapae, common.

Pieris protodice.

Anthrocharis olympia, not rare.

Colias eurytheme, common.

Colias eriphyle, common.

Danias archippus, rare.

Argynnis idalia, one differing a little from eastern species.

Argynnis edwardsii, not common.

Argynnis nevadensis, not common.

Argynnis cypris, rare.

Argynnis sp., one.

Euptoieta claudia, one of the most common (averaging small in size).

Melitaea, three species; not common and local.

Phyciodes tharos, rather common.

Phyciodes carlota, quite common.

Grapta zephyrus, one.

Vannessa antiopa, not common.

Vanessa californica, one.

Vanessa milberti, rare.

Pyrameis cardui, not rare.

Pyrameis ? sp. nov. sp., possibly Hy. Edy. Hybrid caryae et atlanta.

Limenitis weidmeyerii, rare and local.

Limenitis disippus, rare and local.

Coenonympha ochracea, rather common.

Satyrus alope-olympus, rare. 
Satyrus oetus, rare.

Satyrus charon, rather common.

Chionobas varuna, several specimens taken at ranch in July, 100 miles east of Miles City.

Thecla niphon, raro and local.

Chrysophanus hypophlaeas, not rare.

Chrysophanus rubidus.

Lycaena melissa, common.

Pamphila, two or three species, all rare.

Pyrgus tessellata, common.

Pyrgus sp., not common.

Pholisora catullus, common.

Eudamus tityrus, one.

Eudamus sp. one.

-C. A. Wiley in Entomological News for February, 1899. 


\section{Genus BRENTHIS, Hubner.}

Butterfly-Small or medium size; in form and color very much like Argynnis.
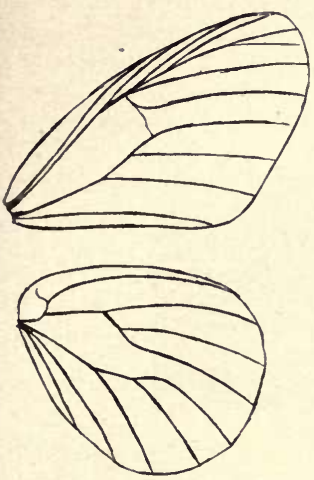

Fig. 55, Venation of Brinthis myrina.

Egg-The eggs are subconical, almost twice as high as wide, truncated at the top, and marked with thirteen or fourteen raised longitudinal ridges connected by a multi. tude of small cross ridges.

Larva-Smaller and not as dark in color as the larva of Argynnis. They feed upon violets.

Chrysalis-It is pendant, about six-tenths of an inch long, and having two rows of sharp conical tubercles on the back.

\section{GENUS BRENTHIS.}

\section{Key to Species.}

1. Basal part of wings not differing from the rest,

2. Under side of wings with silver spots; ocellus at base of hind wings

myrina

3. Under side of wings without silver spots and ocellus; a purplish ferrugenous color at the apex, bellona. Cinnamon brown at the apex of fore wings; hind wing crossed by a yellow band formed of star-like spots; black ocellus at base of wings,

helena.

\section{THE SILVER BORDERED FRITILLARY.}

\section{Brenthis myrina, Cramer. Figs. 55, 56.}

Butterfly-The upper side of the wings is fulvous; the black markings are light; the borders heavy. The fore wings on the under side are yellowish fulvous, ferruginous at the tip, with the marginal spots lightly silvered. The hind wings are ferruginous, mottled with buff. The spots are small and well silvered. Expanse male, 1.40 inches; female, 1.70 inches, $43 \mathrm{~mm}$.

Egg-The egg is conoidal, about one-third higher than wide, marked by seventeen vertical ribs, between which are a number of delicate cross ribs. It is pale greenish yellow in color.

Caterpillar-In its final stage it is about seven-eighths of an inch long, dark olive brown, marked with green; the segments being adorned with fleshy tubercles armed with needle-shaped projections.

Chrysalis-It is brownish yellow, spotted with dark brown spots, those of the thoracic and first and second abdominal segments having the luster of mother of pearl.

Distribution-It has a wide range, extending from New England to 
Montana, from Nova Scotia to Alaska, and southward along the ridges of the Alleghanies into Virginia and the mountains of North Carolina. It has been taken rather abundantly at Crow Creek, Flathead Indian Reservation; at Missoula; at Rimini, 5,500 feet, near Helena, by Brandegee. Taken by Barnes at Aldridge.

One day in July, while camped at Crow Creek along the main wagon road between Selish and Polson Brenthis myrina was found abundantly in the grassy creek bottoms. Almost invariably they were taken on the large blue Erigeron macranthus, common in the western part of the state. The afternoon was warm, and was spent almost entirely in butterfly collecting. Nearly all the specimens taken were of this species.

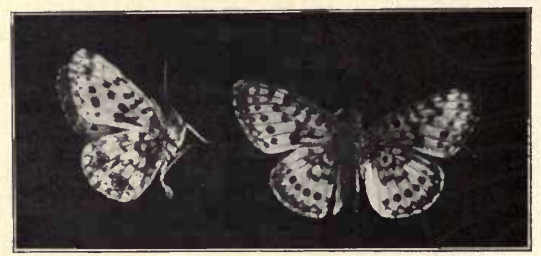

Figs. 55 and 56. Brenthis myrina, upper and lower surfaces.

August 8, 1904, an afternoon was spent at the upper end of Swan Lake after insects. Brenthis myrina was the only common species, resting occasionally on the blue Erigeron or white Achillea. Several dozen were secured, the return to camp revealing two deer in the marsh.

One morning during the last week in August, 1903, as I was wading through the tall wet grass, at the upper end of Swan Lake, just after sunrise, a butterfly was rather abundant above the tops of the grass. The dew was wet and heavy, and no net was at hand. Batting down an insect with my old hat it proved to be of this species. It may be called common west of the range.

THE MEADOW FRITILLARY.

Brenthis bellona, Fabricius. Fig. 57.

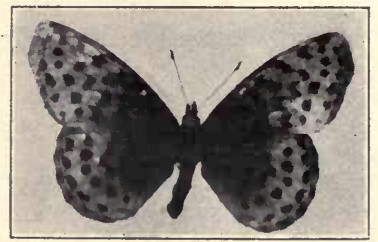

Fig. 57. Brenthis bellona.

Butterfly-Pale fulvous on the upper side, with the dark markings on the inner half of the wing narrow, but more or less confluent. The 
dark markings on the outer margin are slighter. On the under side the fore wings are pale fulvous, spotted with purple at the tip and outer margin. The hind wings below are ferruginous, mottled with purple. Expanse, 1.65-1.80 inches, 41-46 $\mathrm{mm}$.

Early Stages-Similar to that of B. myrina, but the caterpillar in its mature form differs in not having the spines on the second segment of the body lengthened as in that species. Chrysalis, bluish gray in color, marked with dark spots.

Distribution-The butterfly is very common in the whole of the northern United States, as far south as Virginia. It occurs throughout Quebec, Ontario, and British America, as far west as the foothills of the Rocky Mountains. In the state taken by Elrod at Missoula and at Swan Lake; by Brandegee at Rimini, near Helena.

THE HELENA FRITILLARY. Brenthis helena, Edwards, Fig. 58.

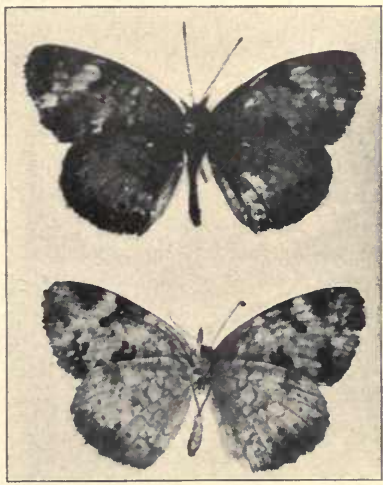

Fig. 58. Brenthis helena.

Butterfly-The wings on the upper side are fulvous, greatly obscured by brown at the base of the fore wings and along the inner margin of the hind wings. The usual markings are light, and the marginal border is also not so heavily marked as in B. myrina. The fore wings on the under side are pale fulvous laved with ferruginous at the tip. The hind wing brightly ferruginous, with small yellow marginal spots and paler spots inclining to buff on the costal border and at the end of the cell, about the region of the median nervules.

The female is very much like the male on the upper side, but the ground color is paler. On the under side the markings are more con: spicuous. Expanse, 1.40 inches, $35 \mathrm{~mm}$.

Early Stages-Unknown.

Distribution-Helena appears to be a common species in Colorado, Montana and New Mexico. It is subject to considerable variation, both 
in the intensity of the coloring of the under side of the wings and in the distinctness of the maculation.

The collection contains two from Missoula and three from Flathead Lake. Cooley has specimens from near Bozeman June 27, 1900, at 6,800 feet, and July 12,1900 , at 8,000 feet.

\section{THE CHECKER-SPOTS. \\ Genus Lemonias, Fabricius.}

This group includes some of the smaller members of the Nyphalinae. The color of the wings is sometimes black, with red and yellow spots; sut it is usually fulvous, with the fore wings broadly margined, especially at the apex, with black, and crossed by many irregular lines of black. About fifty species occur in this country.

\section{Key to Species.}

1. General color black, with a terminal border of red spots; spotted with red and yellow

General color red or fulvous, very little black

General color brownish black

2. Under side brick red with the yellow repeated, size 1.75 to 2.50 inches, 45-64 $\mathrm{mm}$.

Under side brick red, the yellow wanting

chalcedon.

Under side with small spots.

Smaller, about 1.50 inches, $38 \mathrm{~mm}$., more red and yellow

cooperi.

brucei

Black above, a row of small, marginal, brick-red spots, size small

taylori.

3. Under side of fore wings fulvous, with a little yellow at the apex; hind wings with a great deal of yellow

whitneyi.

Basal area black

Under side red, often one row of yellow spots

hoffmanni.

nubigena.

Under side of hind wings heavily and regularly banded with yellowish white spots, possessing pearly luster

4. Both wings with marginal rows of red spots acastus.

\section{THE CHALCEDON CHECKER-SPOT.}

Lemonias chalcedon, Doubleday and Hewitson. Plate IV, Plate I.

Butterfly-Male and female are much alike. The wings are black, spotted with red and ochreous yellow. On the under side they are brickred with the spots of the upper side repeated, and in addition at the base a number of large and distinct yellow spots. Expans?, ma:e, 1.75-2.00 inches, 45-51 mm.; female, 2.50 inches, $64 \mathrm{~mm}$.

Early Stages-The egg is pale yellowish when first laid, pitted at the base, and ribbed vertically above. The caterpillar is black, with the bristles projecting on the segments quite long. The chrysalis is pale gray, blotched with brown. The food plants are Mimulus and Castilleia.

Distribution-It is common in northern California. In Montana is has been taken abundantly at Missoula. One was captured at Geyser Basin, National Park. 


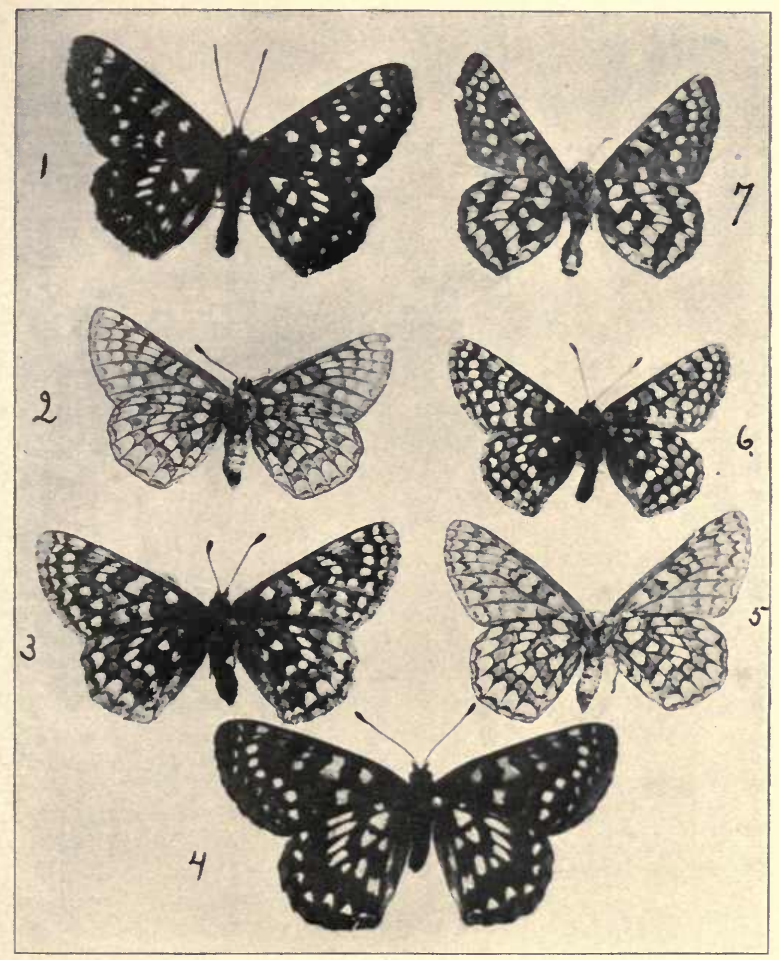

Lemonias chalcedon, upper surface 1 and 4 ; lower surface, 7; Lemonias anicia, upper surface, 3 and 6 ; lower surface, 2 and 5. 

THE ANICIA CHECKER-SPOT.

Lemonias anicia, Doubleday and Hewitson. Plate IV.

Butterfly-Smaller than chalcedon, with a great deal of red on the basal and discal areas of both wings upon the upper side. Expanse 1.50 inches, $38 \mathrm{~mm}$.

Early Stages-These are unknown.

Distribution-L. anicia is found in Colorado, Montana, Washington, and British America. The University of Montana collection embraces specimens from Geyser Basin (13), Missoula (3), Aldridge (1). Coubeaux calls it tolerably common in the mountains near Big Sandy.

\section{TAYLOR'S CHECKER-SPOT.}

\section{Lemonias taylori, Edwards. Fig. 58.}

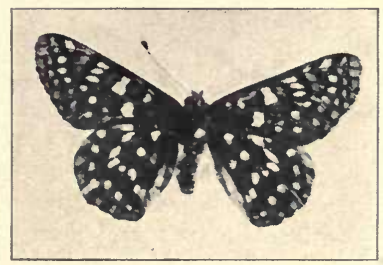

Fig. 58. Lemonias taylori.

Butterfly-Expanse of male, 1.25 to 1.50 inches, $32-38 \mathrm{~mm}$; female, 1.50 to 1.75 inches, $38-45 \mathrm{~mm}$. Ground color black above; a row of small marginal brick-red spots, largest at the apex; two rows of small light yellow or almost quite white spots across fore and hind wings, the outer row on fore wings sometimes reduced to mere specks; on the hind wing there is usually a row of brick-red spots between the rows of yellow spots; within these rows there are about three or four basal yellow spots no larger than the largest spots in the rows; the cell of the fore wings has a small basal yellow spot, then a larger red bar sometimes broken, followed by three yellow dashes making a bar, a large yellow spot, about the middle of the wing below the cell; costa of fore wings brick red, heaviest at the base; the under side is brick-red, the spots above repeated and much larger; on the fore wings the yellow spots are washed over by red, and almost lacking on hinder part of wing; legs, palpi, sides of abdomen brick-red; under side of abdomen same color as yellow spots.

Early Stages-The food is said to be the ribwort plantain (Plantago lanceolata Linn.)

Distribution-It is reported from Vancouver's Island. Prof. Cooley has one specimen from Cascade, on the Missouri river, one from Gallatin County, and one from Missoula; Barnes has several from Aldridge.

\section{BRUCE'S CHECKER-SPOT, Lemonias brucei, Edwards.}

Butterfly-Male: Expands from 1.5 to 1.7 inch 38 to $40 \mathrm{~mm}$. Upper side brown-black, marked with spots of red and yellow in transverse bands; there are three well-marked varieties, in one of which red pre- 
dominates, sometimes almost to the exclusion of yellow; in another red and yellow, much as in other allied species; on the third much yellow, very little red; so that the black surface is more exposed than in many species.

1. The red form. The spots dull; the common marginal row wholly red, the submarginal row sometimes red on primaries, sometimes red partly replaced by yellow, and secondaries always red and yellow; the the third row is red and yellow on primaries, red on secondaries, the fourth row just the reverse of this; at end of cell on primaries a short red and yellow band, in the cell four spots, red and yellow alternately, from the arc, the yellow ones very small; on secondaries, a red stripe along upper side of cell, two small yellow spots in cell; fringes black at ends of the nervules, yellow in the interspaces.

2. The spots of the second row red and yellow on primaries, yellow on secondaries; the two next costa sometimes red on the posterior side; the yellow spots in cell of primaries large, and a large yellow patch below cell.

3. Nearly all spots yellow; the marginal red; no other red on secondaries, or a mere trace of it indicating the spots of the third row, which are otherwise suppressed; the submarginal row of primaries represented by a few scales only, as are also the spots in cell.

On the under side all three forms agree; primarles dull red, almost without black; the marginal spots a aeeper red, the next two rows yellow, the submarginal obsolete on lower half; a yellow patch subapical on costa, another outside arc of cell ; the two cellular spots yellow, dusted red.

Secondaries have all the spots clearly defined; the marginal row red, the second row of yellow lunules; the third wholly red; the fourth yellow, the spots of upper half elongated and cut unequally by a black line from costa to lower discoidal nervule; beyond to base red, with a straight row of four confluent spots from costa to sumedian, and a fifth at end of cell.

Female-Expands 1.7 to $1.8 \mathrm{inch}, 40$ to $42 \mathrm{~mm}$. Varies as the male, but some examples still more widely, the yellow spots being very large. On the under side as in the male, except that some examples have the red submarginal spots of secondaries slightly edged with yellow; in the more yellow upper side examples the yellow edging to these spots is broader, and even sometimes extends along the marginal side.

This small Melitaea has long been known in collections, but till recently I myself have seen few of them, and knew nothing of its localities or habits. Mr. Bruce, who took great numbers of examples, says: "I found it only on high mountain tops (in Colorado); this was strictly the rule. These tops are in most cases extensive plains covered with flowers, chiefly yellow compositae, and the Melitaeas in question sit on every blossom in numbers, and are very sluggish-or rather I may say, they sit and cling tightly to the flowers to prevent the brisk wind, that is generally blowing at this elevation, from taking them away. I have never seen them down the slope lower than a few hundred yards. It is an abundant species on the Snowy Range at not lower than 12,000 feet, and 
must appear early in June, as many of my specimens taken early in July are rather worse for wear."

The species comes also from Montana, Washington Ter., and British America, in the Rocky Mountains. (The above is the original description in Can. Ent.)

\section{THE ACASTUS CHECKER-SPOT.}

Lemonias acastus, Edwards.

Butterfly-Expanse, 1.50 to 1.60 inches, $38-41 \mathrm{~mm}$. Prevalently fulvous upon the upper side, and on the under side of the hind wings heavily and somewhat regularly banded with yellowish-white spots, possessing some pearly lustre.

\section{Early Stages-Unknown}

Distribution-Nevada, Utah, Montana. We have not taken it.

\section{HOFFMANN'S CHECKER-SPOT.}

Lemonias hoffmanni, Behr.

Butterfly-Expanse, 1.35 to 1.45 inches, 35 to $37 \mathrm{~mm}$. General style of marking similar to L. whitneyi, but with the basal area black, and the black markings toward the outer margin not so heavy, giving it here a more fulvous appearance. Under side much as in whitneyi, but the yellow markings are more prominent. Subject to much variation.

Early Stages-Unknown.

Distribution-Found in California, Oregon, Nevada, Colorado, Montana. We have not taken it.

\section{THE LEANIRA CHECKER-SPOT.}

\section{Lemonias learnira, Boisduval.}

Butterfly-Expanse, 1.50 to 1.75 inches, 38 to $45 \mathrm{~mm}$. Ground color brownish-black, fulvous on the costa, with submerged median, and basal rows of yellow spots. Both the primaries and secondaries have a marginal row of red spots, and the former have in addition a sub-marginal row of such spots. The under side of the primariez is reddish fulvous, with the markings of the upper side reproduced. The secondaries have a marginal row of crescents, then a black band inclosing yellow spots, then a median band of long yellow crescents. The remainder of the wing to its insertion is black, spotted with yellow.

Early Stages-Unknown.

Distribution-Colifornia, Arizona, Nevada, Montana, British America. We have not taken it, nor is it in any of the collections.

\section{THE CLOUDED CHECKER-SPOT.}

\section{Lemonias nubigena Behr. Fig. 60.}

Butterfly-Expanse, 1.20-1.50 inches, $30-38 \mathrm{~mm}$. Small, characterized Jy the red ground color of the upper side of the wings. The species is susceptible of great variations. The markings are quite similar to those of other species, but the size is small. In the variety Wheeleri the black ground-color is greatly reduced and almost wholly obliterated on parts of the primaries.

Distribution-Found in Nevada. Collected by Cooley at Bozeman. 


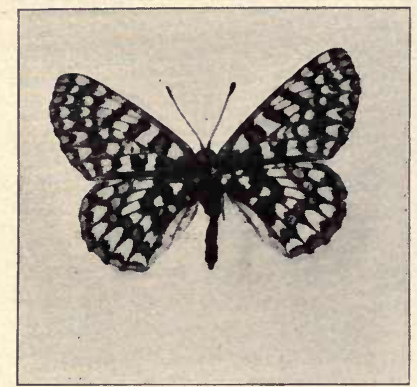

Fig. 60. Lemonias nubigena, from Colorado.

WHITNEY'S CHECKER-SPOT.

Lemonias whitneyi, Behr. Figs. 61 and 62.

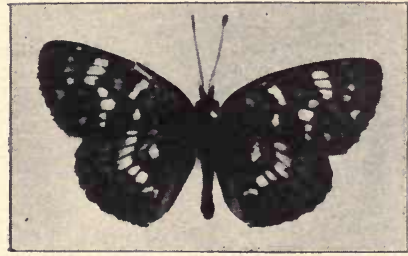

Fig. 61. Lemonias whitneyi.

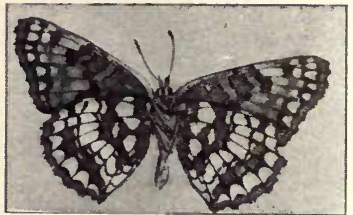

Fig. 62. Lemonias whitneyi, under side.

Butterfly-Fulvous upon the upper side. Prominent yellow bands on under side of hind wings. The yellow is more prominent in the male than in the female. Expanse male, 1.50 inches, $38 \mathrm{~mm}$; female 1.70 inches, $44 \mathrm{~mm}$.

Early Stages-Altogether unknown.

Distribution-It ranges from California into Nevada, north to Montana.

Taken at Sinyaleamin lake in the Mission Mountains by Elrod; near Helena by Brandegee; in Bridger canyon and Gallatin county, elevation 7,500 feet by Cooley; Miles City by Wiley.

\section{COOPER'S CHECKER-SPOT, Lemonias cooperi Behr.}

Butterfly and Early Stages-This species is very similar to chalcedon, but the want of the yellowish halo around the lunulae of the brown band on the under side, is a very positive diagnostic character. The brown color of the bands also is always of the same somber hue as that of the under side of the fore wings, and never of the fiery brick red that colors this fascia on the under side of chalcedon, forming a perceptible contrast to the somber coloring of the under s:de of the fore wings, which is the 
same in chalcedon and cooperi. With all these well marked differences, the two species look so much alike, that it would have been a long time before cooperi would have been recognized as a distinct species, if it had not been for the striking difference of its caterpillar, which was discovered by Mr. Lorquin near Clear Lake on a species of Scrophularia. This caterpillar is much more elongated than that of chalcedon. It is nearly of the shape and coloration of that of the European artemis, brimstone yellow, with a dorsal and a lateral black stripe. We were quite justified in expecting from such a caterpillar something strikingly different from the very common type of chalcedon. But to our surprise our chrysalids gave us a series of crippled butterflies, which could scarcely be distinguished from chalcedon. Since that time I have received a well developed specimen through the kindness of Baron Koels, who caught it with several other insects on an excursion to Mount Tamal Pais.

It is pretty certain that cooperi will be found in many other localities, as it is only its similarity to our most common vernal butterfly, the chalcedon, that makes it escape our attention."

(The above was kindly copied by M. E. Hyde, Asst. Sec. Calif. Acad. Sci., from Behr's original description as given in the Proceedings for 1863-68, Vol. 3, p. 90.)

Distribution-Found in Washington, Vancouver's Island, and the Big Horn Mountains, Montana. 


\section{THE CRESCENT SPOTS.}

Genus PHYCIODES, Doubleday. Fig. 63.

Butterfly-Generally quite small. Their wings on the upper side are fulvous, or brown, with black margins, spots and lines, and with the under side of the wings reproducing the spots of the upper sile. Of the
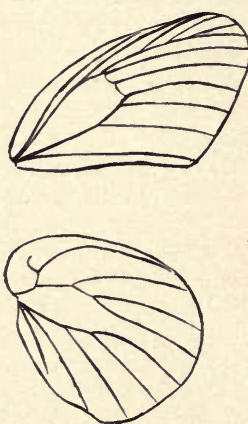

Fig. 63. Venation of Phyciodes. spots of the under side of the wings one of the most characteristic is the pale crescent situated on the outer margin of the hind wings. In the neuration of the wings these butterflies are much like Lemonias.

Eggs-The eggs are always higher than broad, having a thimble-like appearance.

Caterpillar-The caterpillar is cylindrical, marksd with longitudinal stripes, and adorned with tubercles. They do not so far as known weave webs.

Chrysalis-It is pendant, with the head slightly bifid. The color is generally some shade of pale gray, spotted with black or brown.

They are found in South and Central America, the United States and Canada.

\section{GENUS PHYCIODES.}

Key to Species.

1. Broad central band of white or light buff on under side

Central band of under side narrow or wanting, sub-marginal row of spots small

3.

2. Sub-marginal row of spots on under side with no more than one pupiled with white

3. Upper side of fore wings with fulvous bands carlota.

Upper side of fore wings with whitish bands

4.

5.

4. Fulvous band broad, narrow black border tharos Fulvous band narrow, deep border

5. Spots on hind wings above pupiled with black pratensis Hind wings with broad median and narrow sub-marginal whitish bars mylitta 
THE PEARL CRESCENT.

Phyciodes tharos, Drury. Fig. 64.

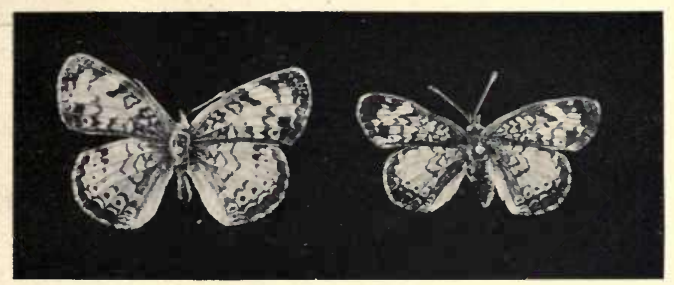

Fig. 64. Phyciodes tharos, slightly reduced.

Butterfly-Expanse, male, 1.25 inches, $32 \mathrm{~mm}$.; female, 1.65 inches, $41 \mathrm{~mm}$. Upper surface reddish fulvous marked with black; two rows of more or less coalescing circles near the base of the wing, the first of two circles, the second of four, and an ellipsoid at the end of the cell; a patch of black beyond the cell on the costa and one on the hind margin, sometimes the two being connected by a dentate line. The outer border is broad, black, and through it runs a crenated line with a yellowish or fulvous lunule in the middle, in some examples distinct, in others connected with the central color; black dot near the posterior angle.

Hind wings similar to front wings, the median black band narrower; both light bands are fulvous, and the outer contains a row of black spots.

The under side of fore wings yellowish fulvous, with yellow spots and four black patches, two on the costa before the apex, one at the posterior angle, and one on the hind margin.

The under side of hind wings pale buff washed with umber-brown, the basal half with more or less complete bands of pale spots edged with brown; the row of black spots same as above; a sub-marginal row of lunules, the middle large, silvery, the others more or less obscure. The terminal, costal, and middle brown patches are present in some examples, the wing being well suffused with brown.

Early Stages-The egg is light greenish yellow. The caterpillar, which feeds upon various species of aster and allied compositae, is dark brown after the third moult, its back dotted with yellowish and adorned with short black bristly spines, which are yellow at the base. The chrysalis is grayish white, mottled with dark spots and lines.

Distribution-This is one of the many dimorphic species. It ranges from southern Labrador to Florida, in fact all over North America, north of Texas and south of the region of Hudson Bay, except the Pacific coast of California. Found in Montana at Missoula, Fish Creek, Ruby Mountain, Crow Creek. Brandegee has it in his collection from Gold Creek. Wiley collected it at Miles City. It is abundant around the Biological laboratory at Bigfork. It is abundant in the Bear Paw Mountains, according to Coubeaux." Dr. Elliott Coues collected it at Milk River July 25, 1874, called by Edwards Marcia, now recognized as a synonym for tharos. 
THE CARLOTA CRESCENT.

Phyciodes carlota Reakirt. Fig. 65.

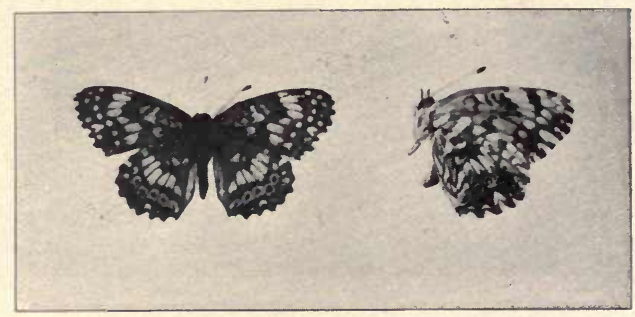

Fig. 65. Phyciodes carlota.

Butterfly-Upper surface black; some fulvous spots near the base of the fore wings; a fulvous band through the middle crossed by the black veins; a sub-terminal row of whitish dots in the broad black terminal border; and a white lunule in the middle of the border near the edge of the wing. In the females there are traces of other white lunules just within the margin. The hind wings similarly marked, except that there is a row of black sub-marginal spots circled with fulvous, and the lunules are faint in the males.

Under side of fore wings fulvous, with three or four not very prominent bars in the cell. a somewhat triangular patch beyond, and a terminal brown black border with the sub-terminal row of spots, between median venules one and two there is a large conical whitish spot, the base on the double terminal line; this double line running in zigzag to the apex, and the inner points silvered more broadly towards the apex, and the inner point sending a white ray to the margin. The same is repeated towards the posterior angle, but with less silver.

The hind wings dark brown washed with whitish, more towards the base, only two yellowish spots in the cell. Near the base is a broken silvery band, and through the middle a silver band crossed by the brown veins, the outer margin dentate. The sub-marginal row of black spots pupilled with white. The margin is similar to that of the fore wings, save that the large spot is silvery instead of whitish.

Distribution-It is found in the southern and western states, Rocky mountains, Montana to Arizona. Wiley has many specimens in his collection from Miles City and Sandstone. He bred specimens in 1890. It is not reported by the other collectors.

THE MYLITTA CRESCENT, Phyciodes Mylitta, Edwards.

Butterfly-Expanse of male, 1.15 inches, female larger. Broadly bright fulvous on the upper side, the dark markings slight; a narrow band of dark on outer edge of both pairs of wings, then a sub-marginal row of crescents, bordered with black; hind wings with a row of small black spots, a black spot on anterior edge and dark base; fore wings crossed by 
two series of black markings like bands, in addition to the preceding; bases dark. Under side fulvous, fore wings with some black at posterior angle; behind this or hind wing, a large light patch; a light patch bordered with dark at middle of outer edge; many light spots on hind wing, making at least two rows.

Early Stages-The food plant is the thistle. The caterpillar is black, yellowish below, with a faint twinned yellow dorsal line and faint lines of the same color on the sides. The spines, which are arranged in six rows, are black. Those of segments four, five, and six, yellow. The chrysalis is dull wood-brown.

Distribution-Washington to Arizona, eastward to Colorado. In the state taken at Helena, July ,2 '03 (1), at Flathead lake, July, '04 (1), and in Yellowstone Park (1). Allen has collected it at Dillon.

THE MEADOW CRESCENT SPOT. Phyciodes pratensis Behr. Fig. 66.

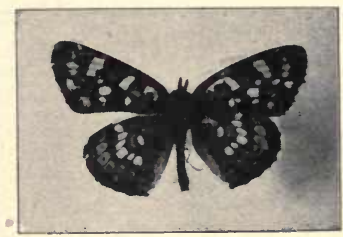

Fig. 66. Phyciodes pratensis.

Butterfly-Expanse, male, 1.15 inches, $30 \mathrm{~mm}$.; female, 1.40 inches, $36 \mathrm{~mm}$. Ground color black or dark brown; in the discal cell of the fore wing a prominent light bar; between this and base of wing several smaller light spots; beyond the bar and between it and the light band a small somewhat triangular fulvous bar; two rows of light fulvous or yellowish spots crossing the wing, the inner lighter and with larger spots, the anterior blending to make a broad bar crossed by the dark nerve lines; a sub-marginal row of lunules, the middle one much larger; border black, with a fringe of light hairs alternating with dark, making small light crescents.

Hind wings similar to the fore wings; the inner band is well marked, broad, crossed by the dark veins of the wing; outer band containing black spots, giving the appearance of fulvous spots pupilled with black, anal edge of the wing black, washed with fulvous; sub-marginal row of light yellow lunules, the third from the anal angle largest; these lunules sometimes almost lacking; border as in front wings.

Under side of fore wings yellowish fulvous with yellow spots and black patches; a rectangular black spot on the middle of the hinder edge; this joins a series of small black lunules and black patches, making a bar across the wing, behind which is a wider yellow bar made in the same manner; in some specimens these are reduced; almost disappearing; but there is always a dark irregular line across the center of the wing; a sub-terminal double black lunule touching the hinder 
margin behind the large black spot; a small costal black dot; apex and base prevailing color of the light bands; a fine brown line a short distance from the outer edge, semicircular between the veins resembling a border of lunules.

Under side of hind wings pale buff washed with umber-brown, the light spots above appearing, usually much lighter than above, even silvery white, many fine brown lines crossing the wings or enclosing light spots; the row of black spots same as above; a sub-marginal row of lunules, the middle one large, silvery, the others more or less obscure, in good examples edged with brown within and without; border as in front wings.

Antennae black, ringed with white at the joints, knobs same color as upper surface; body above dark brown or black, legs color of under surface of wings, under side of abdomen light.

The female has the black markings of the upper side heavier than the male, and all the spots pale yellow. The markings on the under side are heavier than in the male sex. In the male the under side is pale fulvous, spotted with yellow.

Early Stages-Unknown..

Distribution-The range is along the Pacific coast from Oregon to Arizona. Dyar reports it from the Kootenai district of British Columbia. Brandegee has two from near Helena, July 6, 1902; one July 2, 1903. Elrod has one from Flathead lake, July 1904. Several specimens from the Bear Paw Mountains I take to belong to this speciès.

THE CAMILLUS CRESCENT.

Phyciodes camillus, Edwards, Fig. 67.

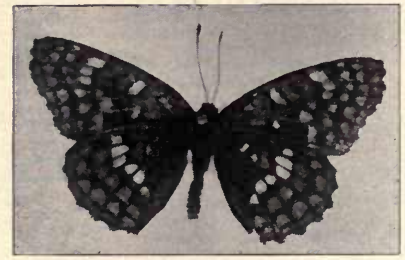

Fig. 67. Phyciodes camillus.

Butterfly-The light spots on the male are paler on the primaries, on the secondaries brighter fulvous. The dark markings on the under side are less pronounced. The female is much like the male. Expanse, male, 1.30 inches, $33 \mathrm{~mm}$; female, 1.50 inches, $38 \mathrm{~mm}$.

Early Stages-Wholly unknown.

Distribution-The species is reported from British Columbia, Montana, Kansas and Texas. In Montana taken at Sinyaleamin Lake, Mission Mountains, Missoula, and at Helena (Brandegee). Cooley has collected it at Bozeman. Collected by Coubeaux at Big Sandy. 


\section{A Chrysalis.}

My little Maedchen found one day A curious something in her play, That was not fruit, nor flower, nor seed; It was not anything that grew, Or crept, or climbed, or swam, or flew; Had neither legs nor wings, indeed; And yet she was not sure, she said, Whether it was allve or dead.

She brought it in her tiny hand To see if I would understand, And wondered when I made reply, "You've found a baby butterfly." "A butterfly is not like this," With doubtful look she answered me. So then I told her what would be Some day within the chrysalis:

How, slowly, in the dull brown thing Now still as death, a spotted wing, And then another, would unfold, Till from the empty shell would fly A pretty creature, by and by, All radiant in blue and gold.

"And will it, truly?" questioned sheHer laughing lips and eager eyes

All in a sparkle of surprise"And shall your little Maedchen see?" "She shall!" I said. How could I tell That ere the worm within its shell Its gauzy, splendid wings had spread, My little Maedchen would be dead?

Today the butterfly has flownShe was not here to see it fly,And sorrowing I wonder why The empty shell is mine alone. Pernaps the secret lies in this:

I too had found a cnrysalis, And death that robbed me of delight Was but the radiant creature's flight! 


\section{GENUS POLYGONIA, HUBNER.}

The Angle-Wings. Fig. 67.

Butterfly-Medium sized or small, characterized by the more or less deeply excavated inner and outer margins of the fore wings, the tail-like projection of the hind wings at the extremity of the third median nervule, the closed cell of the fore wings, and the thick covering of scales on the upper side of the palpi, while on the sides and tops of the palpi there are but few scales. They are tawny on the upper side, spotted and bordered with black; on the under side mimicking the bark of trees and dead leaves, often with a C-shaped silvery spot on the hind wings. The insects hibernate in the butterfiy form in hollow trees, under bark and leaves, and like places.

Early Stages-The eggs taller than broad, tapering upward from the base. The sides are ribbed. They are laid in clusters or in a short string-like series. The caterpillar is cylindrical, adorned with rows of branching spines. They feed upon the nettle, elm, hopvine, and other plants
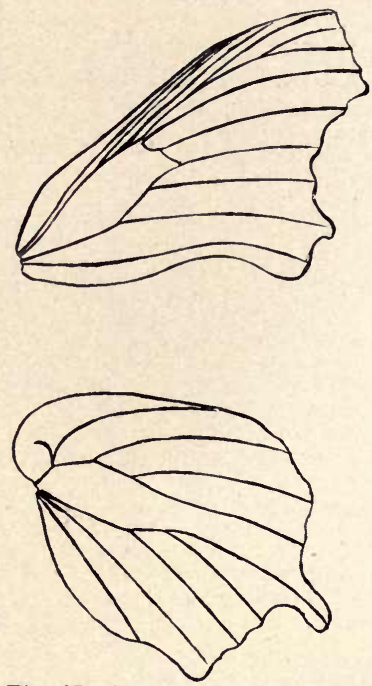

Fig. 67. Venation of Polygonia.

Key to Species.

Small, under side crossed by a pale gray or white band gracilis.

Under side marked with dark and pale shades, heavy black border above 
Under side paler, yellowish brown

More decided markings than the last

zephyrus.

satyrus.

hylas.

Under side pale purplish gray

Under side very dark, paler irrorations

silenus.

THE FAUN.

Polygonia faunus Edwards. Fig. 68.

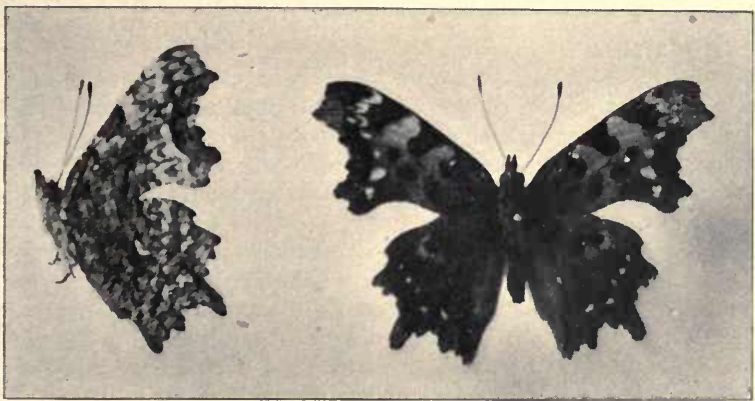

Fig. 68. Polygonia faunus.

Butterfly-Upper surface fulvous, dark, the hind wings darker. Next the apex of the fore wings, the base of both wings, and the inner margin of hind wings dusky. Border of wings broad and dark brown or black, in the fore wings dentate at the apex, and bordered within by a series of sub-obsolete tawny lunules. There are two spots and a bar in the cell, and $a$ bar at the end, but there are only three round spots between the cell and the posterior angle, the lowest supplemented by a shade above it. The spots are very dark or black.

Hind wings with dark ferruginous next the border, shading toward the middle, a series of paler spots next the border and an irregular roof of black spots across the middle.

Under side of both wings dark brown on the base, with an irregular common blackish band across the middle, darkest on its outer edge and within the abdominal margin, where its outline is obliquely serrated. Beyond this band the color is pale brown mottled with grayish white, which is clearest on the fore wings. The whole surface is clouded with vinous, and more or less crossed by fine abbreviated streaks of brown. Apex of fore wings yellow-brown, with three small lanceolate ferruginous spots, the lower enclosing a blue or green point. The outer margin of both wings, below these, is bordered by a series of confluent blue-black, sometimes olive-green spots following the outline of the wing. Within these is another series of rounded spots of the same color. On the disk of the hind wings is a white $\mathrm{G}$ varying in form.

Early Stages-The mature larva is one and a quarter inches long; 
head black, with two branching horns and a few scattered white hairs. Upper side of joints 2 to 6 brick-red, stripped transversely with blue, yellow and black, a few white hairs on joint 2. There are four branching yellow spines, with black tips, on joints 3 and 4 , and six on joints 5 and 6 . Joints 7 to 12 are white, with a faintly marked black stripe along the back, each joint with three transverse yellow bands and two oblique black spots. These joints have each seven spines, all white except the one next the lowest, which is brown. Last two joints black, with seven and four spines respectively. Sides red, with two black bands, the lowest spotted with blue.

The chrysalis is grayish brown Head with two bi-forked horns, the outer point very short; thorax with an elevated keel-like ridge on top, with a small tubercle on each side

The food plants are gooseberry, currant, willow and birch.

Distribution-It is found from New England south to the Carolinas and west to the Pacific.

The collection at the University embraces specimens from Missoula, Sinyaleamin Lake, Flathead Lake, Swan Lake (many).

At Swan lake, August 20, 1903, faunus was abnudant at Bond's cabin, but was very hard to take. It was flying about the lake shore and around the cabins of Bond and Groom, forest rangers, in common with Vanessa J. album, Vanessa californica Polygonia satyrus and P. zephryus. Although quite abundant comparatively few were taken. Brandegee has taken it at Helena.

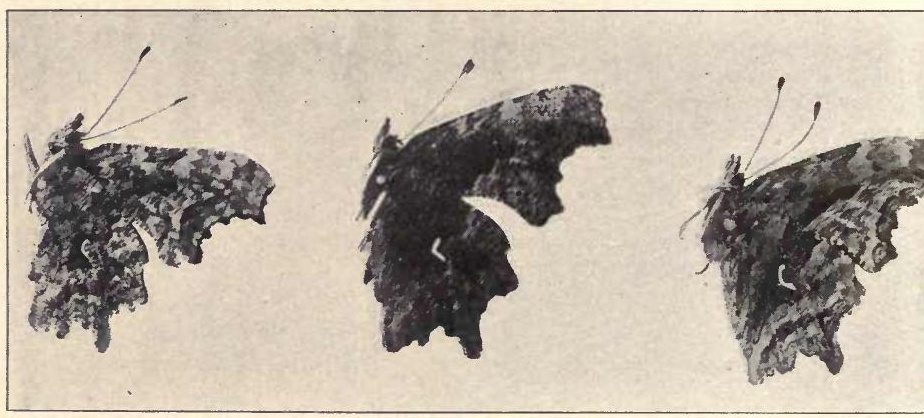

Fig. 69. Polygonia faunus on the left, black satyrus in the middle, zephyrus on the right, under side of wings.

\section{THE SATYR.}

Polygonia satyrus, Edwards. Fig. 69.

Butterfly-Expanse 1.75 to 2.00 inches, $45-51 \mathrm{~mm}$. Tawny or fulvous above. Wings with dark brown, almost black border. A row of lunules of lighter color than ground work within the black border. General color much lighter than faunus. Inside of the lunules is a wash of reddish brown, almost making a line across both wings, more conspicuous on 
hind wings. Bases of wings brownish black Under side of wings dark, with light mottlings and marblings. Apex of fore wings lighter. The light markings make a band across the wings, the inner margin of which crosses the middle of the wings. A light patch usually on costa of fore wings, between light band and base. Wings deeply excised. Legs and feet light colored. Antennae ribbed below, with black clubs, the ends of which are of the same color as the upper surface of wings.

There are two forms. One is very dark below, almost black, with a white open $\mathrm{C}$ like in faunus. The other is much lighter below, the color being a dark brown, the spot on hind wings forming a G, larger. The under surface is broken by darker brown patches extending crosswise of the wings. Above the wings are lighter and the black spots much smaller.

Early Stages-The caterpillar feeds on the nettle.

Distribution-From Ontario to the Western part of the United States. It has been collected in the state by Elrod at Missoula, at Sinyaleamin and Swan lakes; by Cooley at Bozeman, September, 1899; by Brandegee at Helena.

\section{THE ZEPHYR}

Polygonia zephyrus, Edwards. Fig. 70.
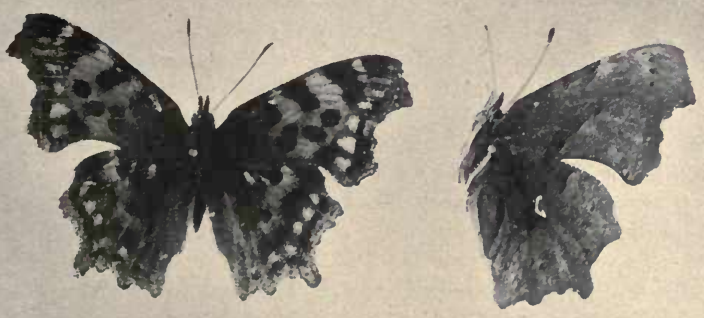

Fig. 70. Polygonia zephyrus.

Butterfly-Upper side of wings similar to faunus and satyrus, fulvous, marked with yellowish toward the outer margins, the dark markings upon which are not as heavy as in the other species. Below the wings are much paler than in faunus or satyrus, reddish brown,, marbled with darker brown lines; the band across the wings is quite light, the female with a row of small light yellowish spots pupiled with black.

Distribution-Rocky Mountain region from Colorado to California, and from Oregon to New Mexico (Holland). Taken in Montana by Cooley 
at Bozeman, by Wiley at Miles City, Brandegee at Helena, and by Elrod at Missoula. One worn specimen from Bear Paw Mountains belongs to this spècies.

\section{THE GRACEFUL ANGLE-WING.}

Polygonia gracilis, Grote and Robinson.

Butterfly-A small species, rather heavily marked with dark or blackish on the upper side. The wings on the under side are very dark, crossed about the middle by a pale gray or white band, shading off toward the outer margins. This light band serves as a means of easily identifying the species. Expanse, 1.75 inches, $45 \mathrm{~mm}$.

Early Stages-Unknown.

Distribution-The species has been found on White Mountains in New Hampshire, in Maine, Canada and British America, as far west as Alaska.

While the species is recorded as having a western distribution it has not been taken by the writers in the state, nor is it reported in the other collections.

\section{THE SILENUS ANGLE-WING.}

Polygonia oreas, var. silenus, Edwards.

Butterfly-Expanse, 2.2 inches, $56 \mathrm{~mm}$. Primaries moderately incised; slightly dentated; tail long, broad and straight; a prominent dentation between tail and inner angle, which last is much pronounced. Upper side deep red-fulvous, clouded with brown-ferruginous next base of each wing and on disks, and spotted with black, hind margins have a broad cinnamon border of nearly uniform width, black with a ferruginous tint; on the inner side a series of separate, pale fulvous spots, yellowish next apex of primaries, irregular in size, lanseolete; primaries have a large sub-apical ferruginous patch on costal margin, another near inner angle, a broad black spot from costa covering the arc, two oval spot in cell placed transversely and sometimes confluent, two others in first and second median spaces, and a large sub-ovate spot on submedian interspace extending partly over the one next above. Secondaries have the entire costal margin brownish-black, a large irregular black patch on disk between upper branch of the sub-costal and the median nervure; a brownish-ferruginous patch at base of the upper median nervules; the whole extra-discal area suffused with ferruginous, passing imperceptibly into the marginal border; fringes fuscous, with a very little white in the emarginations.

Under side mostly in shades of black or black-brown, the entire surface, except where deep black prevails, covered with fine abbreviated streaks darker than the ground; apex of the primaries faintly tinted with olivaceous; costal mragin brown, with a few gray scales near apex, a whitish patch beyond extremity of cell and a smaller one nearer base; base of primaries brown, of secondaries brown next costa, black towards abdominal margin; the disks crossed by a common, broad, black band, very irregular in its exterior outline, on lower part of secondaries merging into the black basal area, outside the band, on primaries and upper part of secondaries, grayish-white for a little space, densely streaked, 
and beyond to margin blackish -brown; the extra-discal points nearly or quite lost on the dark ground; sub-marginal crescents black, obsolescent, often wanting altogether; in the cell of primaries three elongated, narrow, deep black spots, two of which lie along the costal nervure, separated by a very small interval, and each edged by a velvety black line; the third along median nervure, illy defined without such edging; the spot on disk of secondaries dead white, bent at right angles; the lower limb straight, thick abruptly sloping to a point by the cutting away of its upper side; the upper branch narrower, slightly curved, nearly as wide at top as elsewhere and ending bluntly; fringes with the white area more extended than on upper side.

Body above black, covered with ferruginous hairs, below black, sometimes with a gray shade; legs gray-brown, palpi black at base and in front, with whitish hairs at sides, ferruginous at top; antennae black above, fulvous below; club black, fulvous at tip.

Female expands from 2.1 to 23 inches. In shape very like the male; upper side dull yellow-fulvous, the spots large; under side more brown than black, the extra-discal area to margin pretty uniform in shade, the ground being dark gray, nearly lost in the denseness of the brown streaks; sub-marginal points and crescents obsolescent; silver mark of same shape as in the male, often quite as heavy.

Early Stages-Larva unknown.

Distribution-Found in California, Washington, Vancouver Island, and Montana. We have not taken it. 


\section{THE TORTISE SHELLS.}

\section{Genus Eugonia Hubner. Fig. 71.}

Butterfly-Medium sized insects, wings above generally some shade of black or brown, marked with red, yellow or orange. The head is
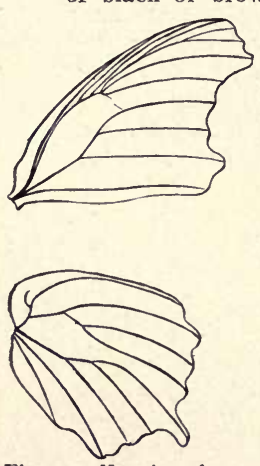

Fig. 7r. Venation of Eugonia J. album. moderately large, eyes hairy, palpi more or less scaled, prothoracic legs feeble and hairy. The cut shows the wing venation. The cell of the primaries may or many not be closed. The cell of the second. aries is open. The fore wings have the outer margins more or less deeply excavated between the extremities of the upper radial and the first meaian veins, at which points the wings are rather strongly produced The hind wings have the outer margin denticulate, strongly produced at the extremity of the third median nervule.

Early Stages-The eggs are short, ovoid, broader at the base, ridged at the summit. They are generally laid in large clusters upon the twigs of the food plant. The mature caterpillar is cylindrical, adorned with long, branching spines in longitudinal rows. It feeds upon the elm, willow, and poplar. The insects hibernate in the imago form, and are among the first to appear in the spring.

THE COMPTON TORTISE. Eugonia j. album, Boisduval Leconte. Fig. 72.

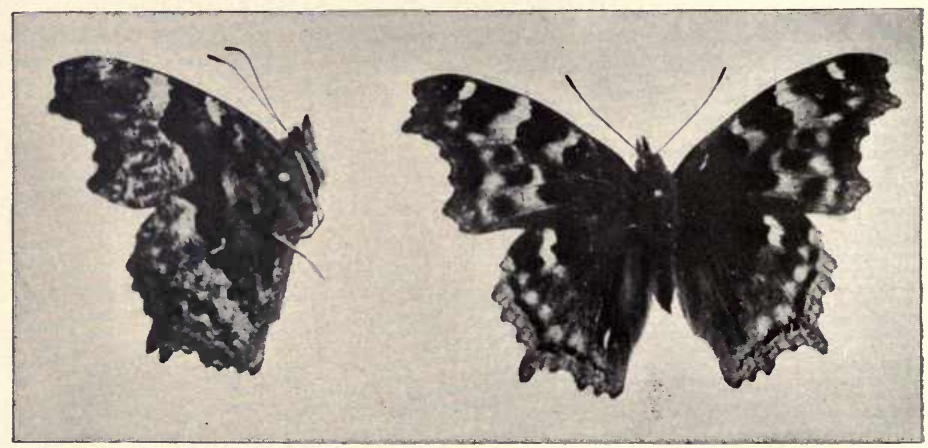

Fig. 72. Eugonia j. album.

Butterfly-Expanse of wings, 2.50 to $2.75 \mathrm{in}$., 64 to $70 \mathrm{~mm}$. Upper surface dull yellowish, dusky at base, washed more or less with rusty brown, especially on the basal half. Outer border of fore wings dull black with a double crenate line and two more or less large costal bars-one at the end of the cell, and the other between the cell and a white sub-apical 
patch; a black spot in the cell with three black spots below the cell, the one nearest the base of the wing quite large.

The hind wings have a black and brown border a little within the margin, the yellow outside sprinkled with brown atoms; a large black space below the costa, beyond which is a whitish patch.

Under side grayish brown, the usual darker band across the middle which on the hind wings is but little darker than the base; beyond this greenish white the whole surface finely reticulated with brown lines. There are the usual three elongate patches edged with dark brown in the cell of the fore wings. The submarginal row of ashy-blue lunules between these and the median band. The lunules do not reach the apex of the fore wings.

Early Stages-The mature larva is two inches, $50 \mathrm{~mm}$. long, head with black markings on the sides, thickly set with little points and with short spines; somewhat cordate, the vertices surmounted by two shining black, thick spines, verticellated near the tip. The dorsal and subdorsal rows of spines shining black except at the base, which is reddisb, with long branches, those of the anterior joints more thickly branched than the otbers. The super- and sub-stigmatted row redd:sh tipped with black.

The chrysallis is one inch long, of a beautiful color, delicately reticulated, with six golden spots on the back.

The food-plant is not known, but Prof. Fernald's surmise is that it may be willow. The butterfly hibernates, the new brood appearing about the middle of August.

Distribution-It is a northern form, being found in Pennsylvania upon the summits of the Alleghanies, and thence northward to Labrador on the east and Alaska on the west. It is always a rather scarce insect, says Holland. See note accompanying"the genus. It is occasionally found at Missoula. Around the biological laboratory at Flathead lake it is often captured. At Schultz's cabin, which is along Aeneas trail over the Swan range, it is quite common, but Bond's cabin at Swan lake is the greatest collecting field in the state, perhaps in the country, for this species. Hundreds were taken here in two or three days in August. 1903. Wiley has one specimen from Miles City, July 15, 1892. 
THE CALIFORNIA TORTOISE-SHELL, Eugonia californica, Boisduval. Fig. 73.

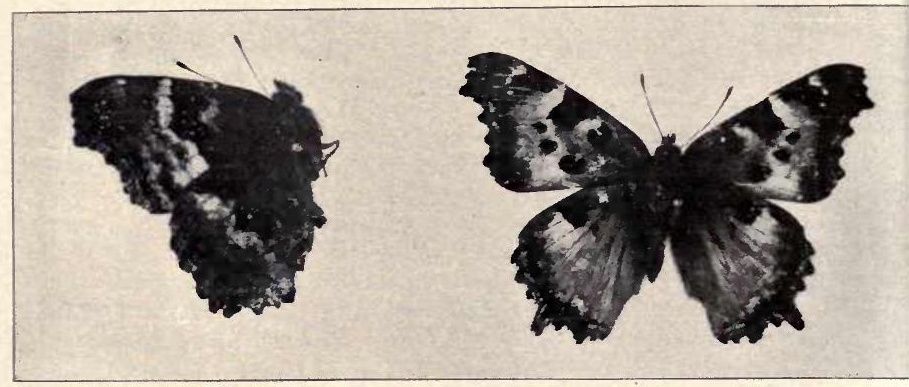

Fig. 73. Eugonia californica.

Butterfly-Similar in general shape and appearance to E. J. album, but easily distinguished by the following peculiarities.

Color-Deep fulvous, spotted with black and having a black border. A black bar across the cell. On the underside dark brown, with a light border. The entire surface marked with fine lines. Expanse 2.00-2.25 inches, $51-57 \mathrm{~mm}$.

Early Stages-The caterpillar feeds upon Ceanothus.

Distribution-It ranges from Colorado to California and as far north as Oregon, east to Miles City.

In 1900 californica was quite common up Hell Gate canyon near Missoula, many having been brought in late in May and early in June. August 20 it was still abundant at Swan Lake, giving evidence of two broods. It is not infrequent about Flathead lake, and evidently covers much unexplored western territory. Wiley reports it at Miles City In 1903 the earliest butterfly at Missoula was a californica taken February 19. 


\section{Eugonia J-Album in Western Montana.}

"This insect is generally rare," writes Holland in his Butterfly Book. In several places in the western part of the state it may be taken in large numbers. At the upper end of Echo Lake, next to the Swan range, we have never failed to take it during our annual pilgramages to the summit, of the range, MacDougal mountain. The old submerged cab:n in the lake is a safe refuge. The cabin on the bank, now deserted, offers a safe retreat from enemies save the human entomologist, who finds here a great opportunity for capturing a rare specimen.

But it is at Swan Lake that Eugonia J. album flourishes in its splendor, magnificence and abundance. This beautiful little sheet of water lies cradled between the Swan and Mission ranges. At its upper end, on the eastern shore, are three cabins. The cabins are along the trail which leads up the lake, through the Swan river forest above the lake to the wagon road leading to Ovando, Missoula, and other places. A clearing of a few acres is around the cabins. Dense woods come to the clearings on all sides. In August the sun is intensely hot in the small open patches about the cabins. About these small log huts, seeking the shade of the rude porch or the interior of the stable, Eugonia J. album was to be had by the dozens. They would alight on the logs of the buidings, the stumps in the clearing, the fence rails, and the bark of the living trees. After alighting they remained perfectly quiet, so that one could carefully adjust the net over them, and with a quick jerk scoop them into the net. In this way a half dozen were often fluttering in the net at once. It was practically impossible to capture them on the wing, so quickly can they dodge and so swiftly do they fly.

When the butterflies alighted on the bark of the fir, cottonwood or birch, upon which they were generally taken, they were almost invisible. It was interesting to see them remain in the same quiet attitude on the top rail of a fence or the skinned $\log$ in the cabin, where they were very conspicuous, as on the trunk of a tree where they were invisible. Protective resemblance was in this species beautifully illustrated, and those who made the trip to Swan Lake in August, 1903, will not soon forget how the insects were controlled by instinct.

Other insects were out, and were captured. Eugonia californica was much less common than E. J. album, while an occasional Polygonia faunus was picked up. The western admiral was rare. Robberflies were out in abundance, as were also bees. Two species of flies were captured which mimic bees, and a dozen species of butterflies were found in greater or less abundance. Nowhere in Montana have we seen more butterflies at one place or captured more in one day than at Groom's cabin at the upper end of Swan Lake, when the species under discussion was taken in such abundance.

In early August, 1904, another visit was made to the cabins at Swan Lake. J. Album was in much less abundance, and difficult to take be- 
cause of the great number of baldfaced hornets which seemed to have possession. Not a Polygonia was seen.

In 1905 album was carce. Its place was taken by the bald-faced hornet. This latter insect practically prevented butterfly collecting.

\section{MOUNTAIN SWARMING OF VANESSA CALIFORNICA.}

During an ascent of Mount Shasta, made in August, 1889, a most interesting occurrence was noted in the flight of countless myriads of butterflies (Vanessa californica) at an altitude far above snow-line.

In our early morning climb of August 29, of the above year, we had left our horses at half past 4 o'clock, at what is known as "Horse Camp," at very near snowline, where there were many small snowfields close about us. Our progress was very slow and tedious, being all of the time over loose, sliding fragmentary rocks, or the almost smooth, hard-frozen surface of the icy snow, and which latter did not soften till long after the sun had swung high enough to shine full upon it. Some little time after daylight, but long before we could see the sun, as he was hidden from us by the high crest of a sharp ridge on the southwest aspect of the mountain (our ascent being made from Sissons, west of the mountain), a few signs of insect life were seen in the shape of "snow-fleas," two or three largewinged grasshoppers, and, occasionally at first, a butterfly. The last two were stiffened by the cold as if they were there from the day previous. The latter insect increased much in numbers as we ascended, and were many of them found in among and under the loose stones as well as a few upon them.

At perhaps half past 9 we came to a point upon which the sun had long been shining, and here they were flying in the air, the flight being in a south-easterly direction. From here they seemed to increase very rapidly in numbers up the remainder of the ascent to well toward the summit. The latter was reached at 11:20 A. M.; the temperature was noted at $42 \mathrm{Fah}$. in the open air. We remained here about a half hour, then passed down by way of the Hot Sulphur Springs, and then out on the southerly face of the mountain. We again encountered our beautiful friends at not farther than six oi eight hundred feet below the extreme peak, and now in countless numbers, filling the air with their flashing wings, and all passing in the same direction as observed during the ascent-towards the southeast. This strange sight continued until we seemed to pass below them, at an altitude of between 11,000 and 12,000 feet. The fact of its being a continuous flight of these insects across the mountain in one direction during the warm part of the day-a period of nearly five hours-is beyond question. That it was in progress one or more days previous to that upon which I observed it is an easy deduction from the fact of the numbers of the insects found among the rocks and stones while yet stiffened by the cold of the night air. How much longer it may have continued I had no means of knowing.

Where they could have come from, in such vast numbers, and what brought them to such a high altitude, is of course a matter of pure speculation.

I had no means of preserving specimens of these insects except to 
place them between the leaves of a notebook; in this way sorje were kept for identification. A gentleman whom I met a few days later pronounced the species to be Vanessa milberti, but after presentation of the account of the flight, with the specimens, before the Biological Society of Washington it was determined for me by Mr. Howard as Vanessa californica.-C. L. Hopkins in Insect Life. 
THE MOURNING CLOAK; THE CAMBERWELL BEAUTY, Euvanessa antiopa, Linnaeus. Fig. 75.

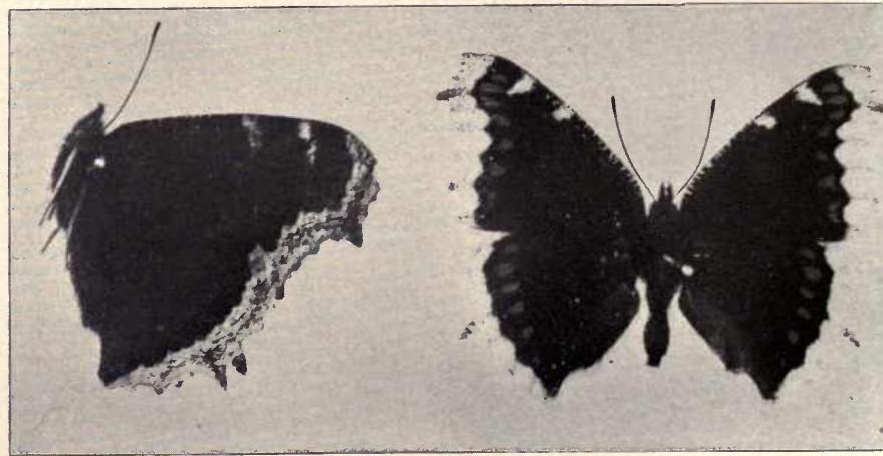

Fig. 75. Euvanessa antiopa, upper and lower surfaces of the wings.

Butterfly-Expanse of wings, 2.5 to 3.5 inches, 64 to $90 \mathrm{~mm}$.

Upper surface rich dark maroon-brown the border yellow sprinkled with brown, and preceded by a black band containing a row of blue spots. The costa is mottled with yellow and contains two yellow patches.

Under surface traversed by numerous fine black abbreviated lines, the outer margin pale buff sprinkled with brown, and preceded by a series of confluent gray, blue-black-edged lunules.

Early Stages-The female deposits the eggs in a cluster round the

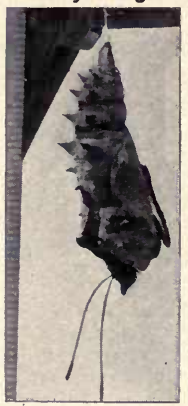
twigs of willow, elms, or poplar near the petiole of a leaf, upon which the young larvae may feed. The mature larvae are two inches long, black, minutely dotted with white which gives them a grayish look; with a dorsal row of brick-red spots. Head black, roughened with small black tubercles. The spines on the body are black, rather long, slightly branching. There are four on joints 2 and 3 , six on joints 4 and 5, and seven each on joints 6 to 12 . The last joint has two pairs of short spines, one behind the other.

The chrysallis is dark brown or gray, with two rows of spines along the back of the abdomen, two on the head in front, three on the edge of the wingFig. 74. Kuvanessa antio- covers on each side, and a thin prominence on the pa, just emerging from middle of the thorax.
the chrysalis.

Distribution-Generally over the North Temperate Zone. It has 
been taken at Missoula, McDonald and Sinyaleamin lakes in the Mission mountains, Flathead lake, and Swan lake. At Missoula antiopa and milberti are the first signs of spring. Branedgee has collected it at Helena, Wiley at Miles City. It is a handsome ornament for a collection. Tolerably common in the mountains near Big Sandy. Collected by Coues along the 49 th parallel in $18 \% 4$.

\section{Stridulation in Euvanessa Antiopa.}

Althougn the sound made by this butterfly without doubt is the expression of certain emotions, be it of anger or of love, since it is not made by the emissions of the breath, we cannot, I think, consider it more than elementary voice, and in the present instance a singularly erratic development of its elements. It may be that

"In Lorranise ther notis be

Full swetir than in this contre,"

for English entomologists are I believe, generally of opinion that the sound which butterflies make is caused by their rubbing their wings together in their ardor. In the Entomologist's Monthly Magazine for February, 1877 , page 208 , I find the following notice:

"In 1872, a female antiopa came into my possession in a hibernating condition, and in that state she would, when disturbed, partially expand her wings, and at the same times was produced a grating sound, which seemed to come from the base of the wings.-A. H. Jones, Shrublands, Eltham."

Let anyone now take a dried specimen of this butterfly from the cabinet and grasping the fore wing by its front edge rub it backwards and forwards over the hinder one, so that the bases meet, but being at the same time careful not to crumible the wings and so produce a false sound. We will then without fail hear the sweet secrets of antiopa, which are beautiful and delicate in expression, recalling the trickle of the brooklet.

I may notice that Vanessa butterflies are renowned and well-known as stridulators on account of their large size, but that nearly all butterflies rub their wings together when under the influence of the emotion of love, and since it is the result of friction to produce a striated surface, many of these smaller ones must have organs of sound too fine for human sense. My own researches have always been circumscribed from a want. of adequate microscopic power.-A. H. Swinton in Insect Life.

MILBERT'S TORTOISE SHELL, Aglais milberti, Godart. Fig. 76.

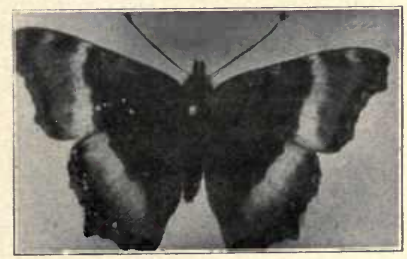

Fig. 76. Aglais milberti. 
Butterfly-Expanse of wings 1.6-2.55.in., 40 to $65 \mathrm{~mm}$. Upper surface brownish black, with a broad fulvous band between the middle and outer margin, paler on its inner edge. On the fore wings the pale band contains a black patch on the costa, with a white spot on one or both sides. There are two fulvous spots in the cell. The border is composed of two parts, the inner black, the outer a black brown, crenate line on each side of which it is a little paler. The black on the hind wing supports a row of violet lunules. Underside dark brown with the usual wavy lines and spots; the outer half yellowish brown with a submarginal of gray blue lunules which are black edged.

Larva-The mature larva is a little more than an inch long, with a black head sprinkled with minute whitish dots, from which spring pale hairs. The body is nearly black above, with small white dots and pale hairs, which give it a grayish color. The spines are arranged as in antiopa, and are black and branching. It has a greenish yellow lateral line above which is a broken line of brighter orange yellow shade. The larvae are found on the wild nettle, and there are two broods in a season.

Chrysalis-The chrysalis is .8 of an inch long, $20 \mathrm{~mm}$., slightly angular, the frontal beaks short, conoidal; thoracis projection forming nearly a right angle; dorsal spines but little elevated.

Distribution-It ranges from the mountains of West Virginla northward to Nova Scotia and Newfoundland, thence westward to the Pacific.

This tortoise-shell butterfly is one of the first harbingers of spring. Uusually it is the first butterfly seen about Missoula, where it is rather common. It is usually quite abundant around the biological laboratory at Flathead Lake, but in the summer of 1903 but very few were seen. Brandegee has collected it at Helena, and Wiley reports it rare at Miles City. At Swan Lake it is occasionally seen, probably about the same in numbers as at Flathead Lake, owing to their close proximity. Coubeaux says it is very abundant all over the country about Big Sandy. Taken by Coues at Chief Mountain, August 22, 1874.

THE LADY BUTTERFLIES, Genus Vanessa, Doubleday. Fig. 77.

Butterfly-Medium-sized insects; the wings on the upper side are

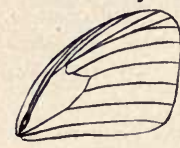
some shade of black or brown, marked with white, red or orange. Head rather large, eyes hairy, palpi more or less heavily scaled. The cut shows the venation of the wings. The outer margin of the wings is dentate. The wings are not angulate, as in vanessa, but are more rounded. The ornamentation of the under side tends to

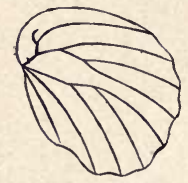

Fig. 77. Venation of vanessa. become ocellate, or marked by eye-like spots. Some are ocellate.

Egg-This is broadly ovoid, being much like the egg of the genus Vanessa.

Caterpillar-In its mature form it is covered with spines.

Chrysalis-It is much like Euvanessa. 


\section{Genus VANESSA.}

Key to Species.

1. Ground color black, band on fore wings and outer margin of hind wings fulvous

Ground color fulvous.

atalanta

ive eyespots on underside of hind wings

cardui.

Four distinct eyespots on hind wings; black bar across middle of the cell of the primaries; tawnier ground color than cardui

Hind wings with two large ocelli underneath

caryae

huntera

THE RED ADMIRAL. Vanessa atalanta, Linnaeus. Fig. 78.

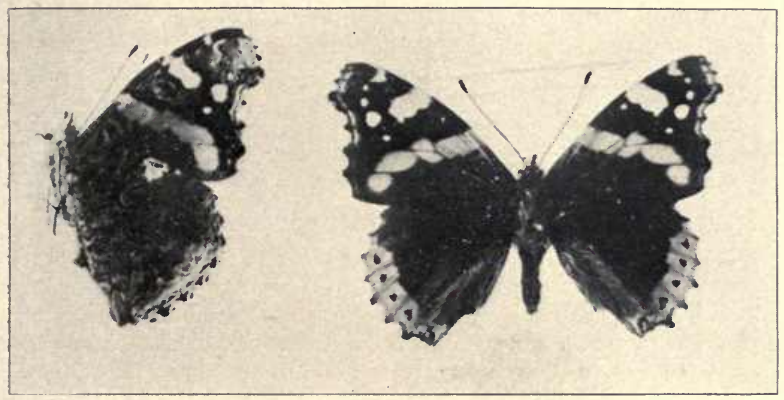

Fig. 78. Vanessa atalanta.

Butterfly-This butterfly is brown above, with a fulvous band on the outer margin of the hind wings, containing brown spots. The fore wings are also crossed by a fulvous band, which begins at the posterior angle and passes through the cell. There is a white bar beyond the cell, also a marginal row of about five spots, the fourth from the costa being the largest. The spots of the upperside reappear on the underside, but the brown is marbled with gray, blue and green and there is a submarginal row of spots of the hind wings. Expanse 2.00 to 2:25 inches, 51 to $57 \mathrm{~mm}$.

Early Stages-The eggs are green, barrel shaped. The young larva is greenish brown, and furnished with ten rows of black curved hairs. In reaching maturity it passes four moults. The mature larva is 1.3 in. long, cylindrical enlarged in the middle and of a velvet black color, sprinkled with fine velvet points. The chrysalis is from .85 to .95 of an inch long, cylindrical. The dorsal tubercles are gilded. The color is usually gray. The food plants are nettle and hop.

Distribution-It is found in the United States generally. During the summer of 1903 it was taken sparingly at the Biological Station at Flathead Lake. It has not been seen at Missoula. It is not in the collections of Wiley, Cooley or Brandegee, and must be very rare in the state. It is reported by Dyar from the Kootenai country. 
THE THISTLE BUTTERFLY or THE PAINTED LADY. Vanessa cardui. Linn. Fig. 79.

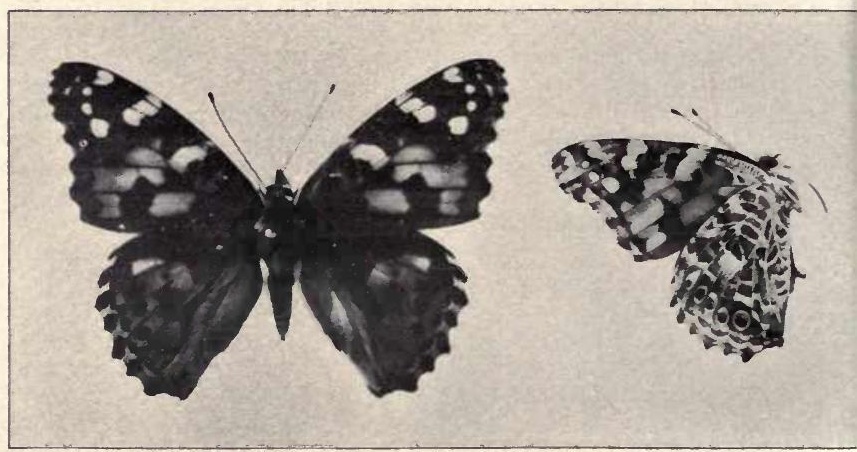

Fig. 79. Vanessa cardui.

Butterfly-Pyrameis cardui, or the Painted Lady, has an upper surface of fulvous color, the apical portion of the fore wings being black. There is a white bar in the apical black portion of the fore wings and a submarginal row of four white spots; the inner ones being the smaller. The underside of the fore wings is red except the apical part which is marked as above. The hind wings have a submarginal row of five black spots. Both wings have a border, the hind wings having a broken one. The underside of the hind wing is marbled with brown, gray and white. The ocelli contain blue. The inner row of the margin is blue or lilac. Expanse of wing 1.75 to 2.5 inches, 45 to $64 \mathrm{~mm}$.

Early Stages-The mature larva is $1.5 \mathrm{in}$. long, cylindrical, rather robust. The general color is a delicate lilac. Between the joints are two lines of bright yellow. The space between the yellow occupied by two narrow black lines and one white one. There are seven rows of tubercles from which arise branching spines. The head is black, stigmata black with some black spots over the body.

Distribution-Most widely distributed of all known butterflies, being found in almost all parts of the temperate regions of the earth and in many tropical lands in both hemispheres. It is double brooded and hibernates in the butterfly state. Found all over Europe, North America, in Africa,-save in the dense jungles of the Congo.- in South America, in Australia and in many islands of the sea; at some times scarce and then at seasons it fairly swarms. (Holland.)

One of these swarms visited Montana in the spring of 1899. During late May and early June there were hundreds and thousands everywhere in the western part of the state, noted especially at Missoula and Helena. So abundant were they that they were noticed by all, and considerable alarm was felt by some lest there should occur later an outbreak of an insect pest. Happily this did not occur. 
It abounds about the biological laboratory at Flathead lake, and specimens showing great variation have been captured. Brandegee has taken it at Helena and Wiley at Miles City. It is abundant in extreme ends of the state. Cooley reports it abundant at Bozeman. It seems to be everywhere one of the most common insects. It is known among entomologists to be the most widely distributed of all butterflies, so far as present knowledges goes. Its food plants are thistles, (Carduus), Urtica, (nettle), Onicus, (plumed thistle), and Altheca (marsh mallow). Coubeaux calls it abundantly around -ig Sandy. Collected by Coues along the 4 th parrallel in 1874 .

THE WEST COAST LADY. Vanessa caryae, Hubner. Fig. 80.

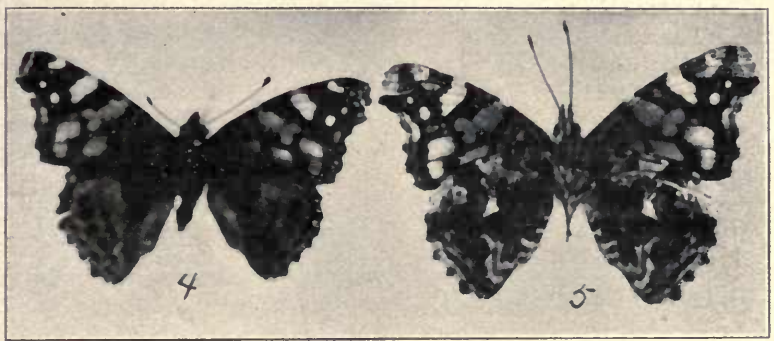

Fig. 80. Vanessa caryae, 4 upper, 5 lower surface.

Butterfly-It is distinguished from $P$. cardui by absence of the roseate tint peculiar to that species. It has a complete black bar across the cell in the primarles. Expanse $2.00 \mathrm{in.}$

Distribution-It ranges Irom Vancouver to Argentina; found as far east as Utah. Two specimens have been taken at Missoula. As it has been taken by no one else Missoula is perhaps as far east as it will be found.

HUNTER'S BUTTERFLY, Vanessa huntera, Fabricius.

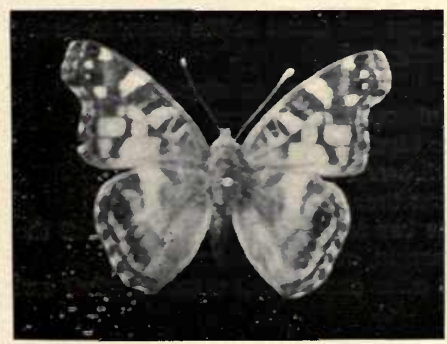

Fig. 80a. Vanessa huntera, natural size. 
Butterfly-Expanse, 2.00 to 2.25 inches, 50 to $64 \mathrm{~mm}$. Upper surface fulvous; a little tawny at base, the apical portion of the fore wings black, this continued as a border to the posterior angle. The apical black contains an oblique fulvous bar beyond the cell, and the submarginal dots as in atalanta, the first two blended, and one farther down in the fulvous. Besides this there are five triangular black marks, two of which are in the cell. The border of both wings consists of three more or less distinct lines, the inner on the hind wings in the form of a shade. The apical portion of the border on the fore wings is washed with lilac; and there is a gray-blue bar at the anal angle. Hind wings have a submarginal row of five black spots, the second and fifth pupiled with blue. Costa black.

The under side of fore wings is red, except the apical portion, which is marked as above. Hind wings marbled with brownish black and white, with two large ocelli. By these it is easily distinguished. The outer border is four black lines, with violet between the two inner.

Early Stages-The mature larva is 1.25 inches, $32 \mathrm{~mm}$, long, the body. velvety black, between the joints four transverse lines of pale yellow alternating with narrow black lines. The food plants are Gnaphalium, Antennaria, Artemisia, and allied species.

Distribution-From Nova Scotia to Mexico. In the state it is reported only by Campbell Carrington and William B. Logan, of the Expedition in 1871, locality not given.

\section{THE MONARCHS, Genus Basilarchia, Scudder.}

Butterfly-Head large; the eyes are large and naked; the antennae moderately long, with a distinct club; palpi compact, stout, produced, densely scaled. The fore wings are sub-triangular, apex well rounded, the lower two-thirds of the outer margin slightly excavated. The first two sub-costal nervules arise before the end of the cell. The hind wings are rounded, crenulate.

Early Stages-Eggs nearly spherical, the surface pitted with large hexagonal cells. The mature caterpillar is cylindrical, the second segment with two prominent rugose club-shaped tubercles; they are strikingly mottled or spotted. Chrysalis suspended by a stout cremaster. They feed upon the leaves of various species of oak, birch, willow, or linden. Three species are found in the state, to be separated from each other by the following key.

1. Ground color fulvous or mahogany

\section{Key to species.}

Ground color black.

archippus

2. Both wings with broad white bands. ivings without broad white bands.

3. Yellowssh white bar near the end of the cell of the fore wings, apex and upper margin, of the same, reddish.

lorquini

Bar and red color absent, and a submarginal series of white spots present. wiedemeyeri 


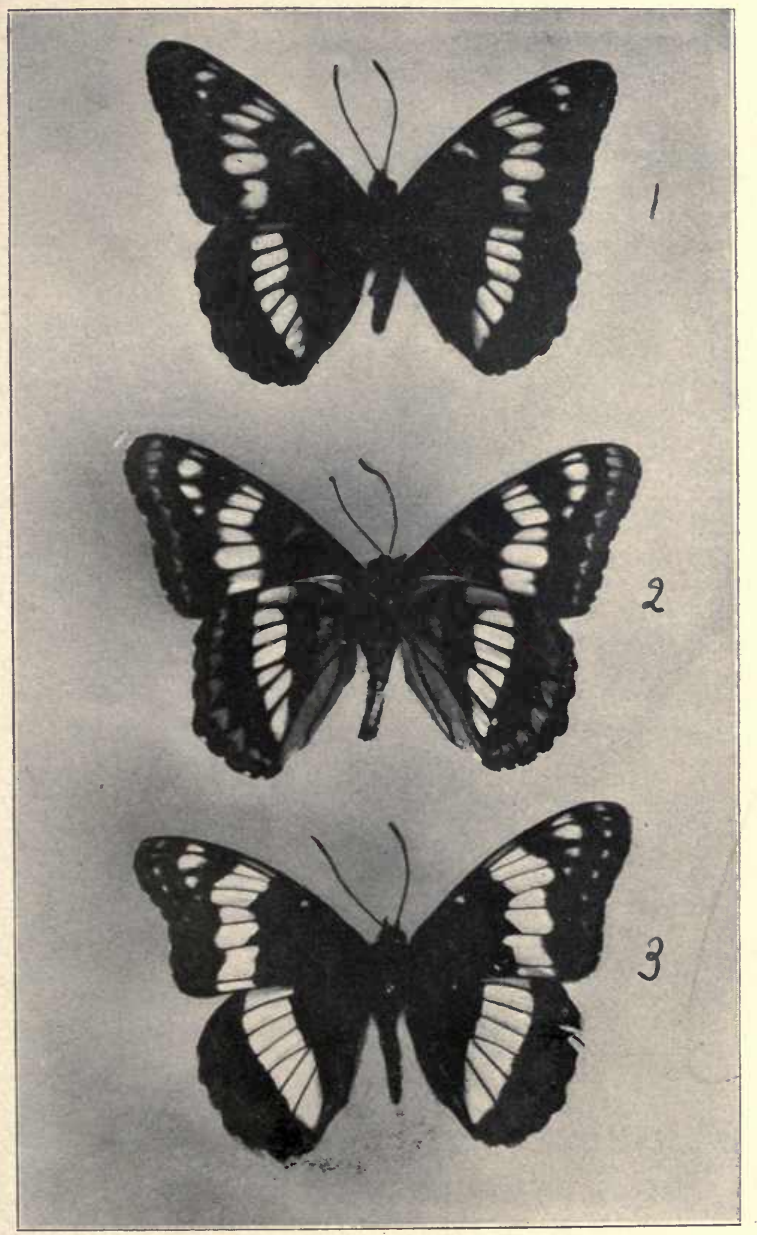

3. Basilarchia wiedemeyeri; 2, lower surface, 1, upper surface of Basilarchia lorquina. 

THE VICEROY, Basilarchia archippus, Cramer.

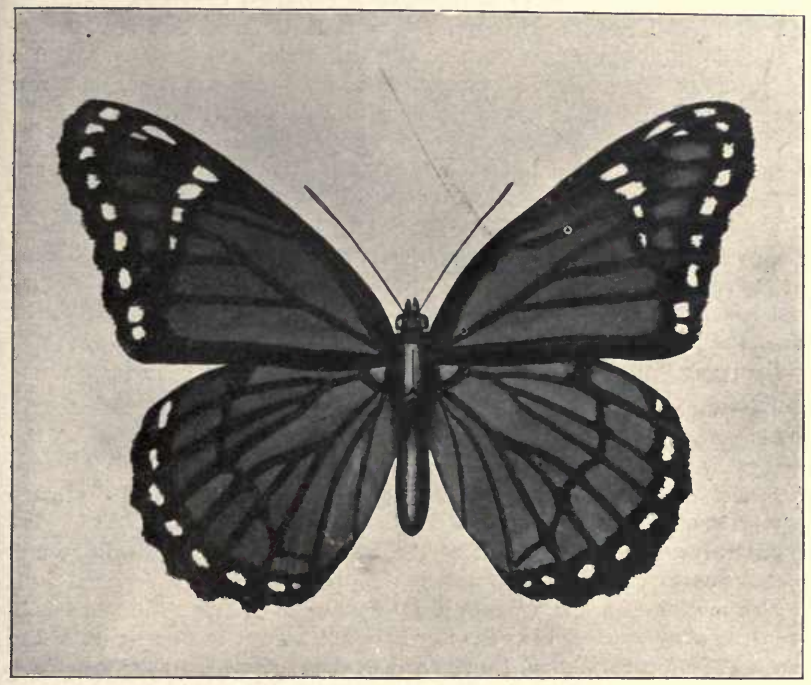

Fig. 81. Basilarchia archippus, From water color drawing by Mrs. Edith Ricker.

Butterfly-Upper surface fulvous, the lines black; on the fore wings a dark triangular patch, containing three white spots on the costa beyond the cell, continued to the posterior angle in a narrow line. A black line crosses the hind wings about two-thirds of the distance from the base. Outer border black containing a row of white spots, and there are two ante-apical white spots; the lower one quite small. Underside similar to upper, paler fulvous. The fringes are black, spotted with white.

Earley Stages-The larva feeds upon willow, popular, balm of gilead, aspen, and cottonwood. It is two or three brooded.

Distribution-Found over nearly the whole of the United States as far west as the Sierra Nevada Mountains, and has been found sparingly even to the Pacific coast, near our northern boundaries.

B. archippus is injurious to the oak and to the wild plum.

This species mimics the Monarch butterfly Anosia plexippus, so abundant in the eastern states. The Monarch is sparingly found in the western part, rather abundant east. The eastern milkweed is gaining a footing along the railroads, and with it the Monarch is probably on the increase. The writer has not taken the Viceroy west of the range, but Mr. E. N. Brandegee has some specimens from Gold Creek, west of the range, which he collected and which the writer has seen. Cooley reports it as occasional near Bozeman, while Wiley calls it rare and local about Miles City. Douglass collected one specimen at Fish Creek.Coubeaux has collected it at Big Sandy. 


\section{WIEDEMEYER'S ADMIRAL Basilarchia wiedemeyeri, Edwards. \\ Plate VII. Fig. 3.}

Butterfly-It may be distinguished from B. lerquina by its wings being crossed with white bars instead of cream ones, and the absence of a bar at the end of the cell and the yellow apex; it has a submarginal row of white spots on both wings. Expanse 3.00 inches, $77 \mathrm{~mm}$.

Early Stages-Caterpillar feeds upon cottonwood.

Distribution-The insect is found on the Pacific slope and eastward to Montana, Nebraska and New Mexico.

We have not yet taken this species west of the Rocky Mountains, although it is not uncommon east of the range. Brandegee has collected it at Helena, Cooley at Mystic Lake, and Wiley at Miles City. Douglas found it at Madison lake and Jasper Mountain. Taken at Big Sandy by Coubeaux.

LORQUIN'S ADMIRAL, Basilarchia lorquini, Boisduval.

Plate VII, Fig. 1, upper, Fig. 2, lower surface.

Butterfly-Easily distinguished from all the other species of the genus by the yellowish white bar near the end of the cell of the fore wings, and the reddish color of the apex and upper margin of the same wings. Expanse, 2.25-2.75 in., 56 to $62 \mathrm{~mm}$.

Caterpillar-The food plant of the caterpillar is poplar, willow, and the choke-cherry.

Distribution-This is a western speries, quite common in most localities in the state west of the range. It is not known to occur east of the range. The University of Montana collection embraces specimens collected by Elrod at various pleces in the Mission Mountains, at Flathead and Swan lakes, at Missoula, and on Mt. Lo Lo.

\section{BUTTER FLIES ON CHIMBORAZO.}

"Even butterflies are found at sea at great distances from the coast, being carried there by the force of the wind when storms come off the land. In the same involuntary manner insects are transported into the upper regions of the atmosphere, 16,000 or 19,000 feet above the plains. The heated crust of the earth occasions an ascending vertical current of air, by which light bodies are borne upwards.

When Bonpland, Carlos Montufar and myself reached, on the 23rd of June, 1802, on the eastern declivity of the Chimborazo the height of 19,286 English feet, we saw winged insects fluttering around us. We could see that they were Dipteras, but it was impossible to catch the insects..... The insects were flying at a height of about 18,226 feet..... Somewhat lower down, at about 2,600 toises $(16,680)$, also therefore within the line of perpetual snow, Bonpland had seen yellow butterflies flying very near the ground.-Humboldt in "Aspects of Nature." 


\section{THE WOOD NYMPHS, THE MEADOW-BROWNS. SUBFAMILY Agapetinae.}

The butterflies belonging to this subfamily are for the most part of medium size, and are generally obscure in color, being of some shade of brown or gray, though a few species are brightly colored. The markings consist almost entirely of eyelike spots, dark pupiled in the center with a point of lighter color, and ringed about with one or more light circles. They are possessed of a weak flight. Most of them are forest living insects, though a few inhabit the cold and bleak summits of mountains and grassy patches near the marglns of streams in the far North.

The family includes chiefly brown butterflies whose markings consist almost entirely of eyelike spots. Some of the western species are brightly colored. The insects are easily recognized by their having some of the veins of the fore wings greatly swollen at the base.

The larvae are cylindrical, tapering more or less toward each end. The candal segment is bifurcated, a character that distinguishes them from all other American buiterfly larvae excepting those of some of the emperors (Chlorippe).

The Chrysalids are rounded; in some cases the transformation takes place beneath rubbish on thè ground without any preparation of cell or suspension of the body. Nearly fifty species have been described from America north of Mexico.

1. Eyes very hairy

Key to Genera.

Eyes naked or nearly so

2 .

3.

2. Outer margin of bind wings angled

Outer margin of hind wings evenly rounded

Enodia

Satyrodes

3. Upper surface of fore wings with eye spots

Upper surface of fore wings without eye spots

5 .

4. Spots ordered by some shade of red

Spots bordered by some shade of yellow

Spots ligbt, color ochreous

Spots bordered by white or gray

5. Lower surface of hind wings mottled

Genus CERCYONIS.

(The Wood Nymphs.)

Key to species.

1. Fore wings with or without a buff band, but with two ocelli alope No buff bands, fore wings with two occelli on fore wings and one on hind wings, both showing above sylvestıs, var. charon

THE COMMON WOOD NYMPH, Ceryonis alope Fabricus. Fig. 83, 84, 82.

Butterfly-Expanse of wings 1.75 to 2.00 inches, male. Upper surface blackish brown, darkest over the basal area; outer margin consisting of two fine parallel lines, a little within which is a black stripe. The fore 


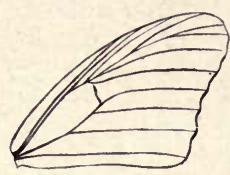

wings have a transverse yellow band beyond the cell, sometimes a little ochraceous, and often more or less encroached upon by the brown ground. On this area are two ocelli, round, black, or variable size, and with or without a central point, which is white with blue scales. Behind the cell is a blackish indistinct sexual dash in the males. The bind wings have

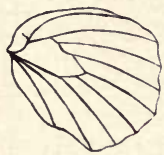

Fig. S2. Venation of cercyonis a small ocellus in a yellow ring near the anal angle (often wanting).

Underside yellow-brown; the band enlarged and of a paler color; the ocelli repeated, enlarged; the marginal lines distinct; the brown area covered with abbreviated darker streaks, which over the base and disks form somewhat concentric broken rings, limited without by a common dark stripe. On the fore wings it is irregularly sinuous from margin to margin, throwing out a rounded prominence against the cell, followed by a rounded sinus on the median interspace. Across the middle of the cell, and below it, a dark stripe; the extra discal area less streaked. The ocelli vary from none to six, the full number being most often present, disposed in two groups of three, the middle one of each group the largest; all black, rounded, in narrow yellow rings, and with white dots in the center edged by blue scales.

Female-This differs from the male in the band being generally

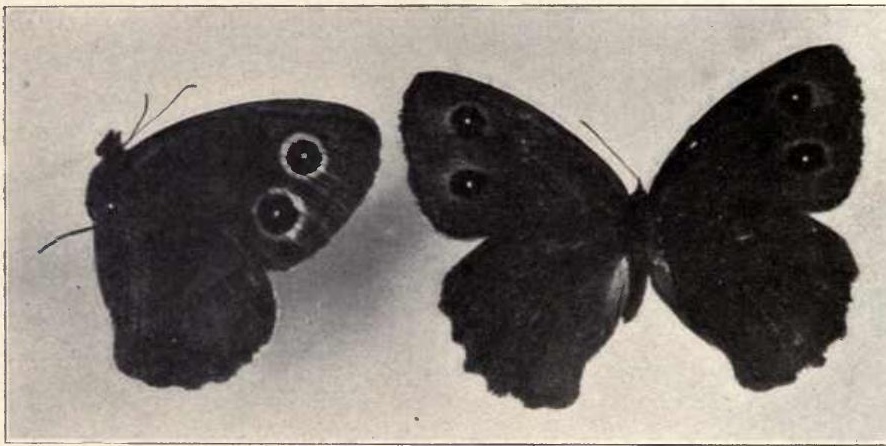

Fig. 83. Cercyonis alope var. nephele, right figure upper surface, left figure lower surface.

broader, clearer, and well defined on both edges, the ocelli well developed, with occasionally additional black points on the hind wings corresponding to the ocelli on the under side. A larger percentage than of the males have no ocelli on the under side of the hind wings.

The above description applies to typical form alope. Variety olympus, Edwards, differs from the above as follows: The males are 
almost black. The ocelli are very small and without wings, but in some examples there is a faint russet or yellowish tint about them, and perhaps on the space between them. On the under side the rings are russet or ochraceous on both wings, and there is a perceptible bronze reflection on the underside of the hind wings, especially in the males.

This form is said to occur from Illinois to the Rocky Mountains, and is found abundantly in Montana. However, many specimens with the broad buff band, as in typical alope are found also, see Fig. 85 . Olympus and nephele are now given as synonyms, so nephele occurs from New Eng. land to the Rocky Mountains. Five varieties for this species are recog. nized.

Early Stages-The egg is conical, marked by about eighteen vertical ridges, lemon-yellow in color, hatching in from fourteen to twenty-eight days. The mature larva is $\mathbf{1 . 2 5}$ inches long, cylindrical, robust, thickest in the middle, with two sharp, conical, divergent tails; color yellow-green, head vivid green, Chrysalis is a little more than half an inch long, cylindrical. The butterfly emerges in fourteen days. The larva feeds on meadow-grass, and the butterfly is found mostly in the open fields or open woods.

Var. nephele-Largest of the forms, with buff bands. Ariana is also found in Montana. This is a decidedly dwarfed form, and one that is quite dark. The ocelli are small and well defined.

This species is abundant during July and August around Flathead Lake. In searching for insects nephele skirts the roadside by the open woods or undulates through the woods in graceful flight. It becomes so abundant that catching it becomes tame. The specimens show great variation; the species is recognized as being exceedingly variable. At Missoula it is quite common; Brandegee has taken it at Gold Creek, and Wiley at Miles. City. Coubeaux has many specimens from Big Sandy. Coues collected from boopis at Chief Mountain July 21, 1874, a single specimen.

THE DARK WOOD NYMPH, Cercyonis sylvestris, var. charon. Edwards. Fig. 84.

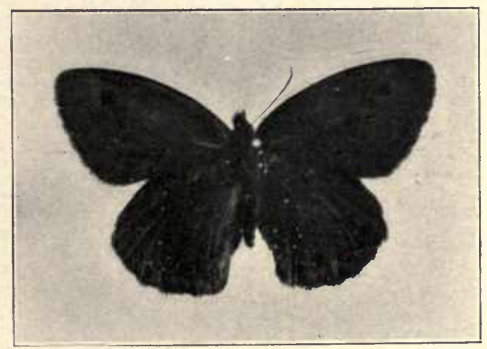

Fig. 84. Carcyonis sylvestris, var. charon. 
Butterfly-Expanse of wings, 1.50 to 1.75 inches. The male is dark in color; the female is paler. There are two eye-spots on the fore wings in the usual location, indistinct on the upper, distinct on the lower side of the wings. The under sides of the wings are variable. In the type they are dark; in other specimens they are paler. They may or may not have ocelli on the secondaries. Both the fore and hind wings are abundantly and evenly marked by little striae, and crossed on either side of the median area by obscure, irregular, transverse dark lines, either one or both of which may be wanting in some specimens.

Early Stages-The caterpillar is green, cylindrical, tapering before and behind, marked with longitudinal pale-yellow lines. The chysalis is green or black, striped with narrow white lines. The larva feeds on grasses.

Distribution-It is found in the Northwest, ranging from British Columbia as far as Mexico. In Montana it has been taken abundantly by Wiley at Miles City and Sandstone. Brandegee has taken it at Mt. Ascension near Helena. Allen has specimens from Dillon. Coues collected it in 1874 at Frenchman's river and Chief Mountain. 


\section{Collecting Butterflies in Montana.}

July 22, 1903, was a hot day. For several days the sun had been warm. We were camped on the bank of Bigfork or Swan river at its outlet to Flathead Lake. Our little laboratory, constructed escpecially for out door work, had been a scene of activity within, but no one could stand it long in the swamps or woods on account of the mosquitoes. For two days the little fellows had been especially persistent and villainous. This was taken to be a sign that they would soon go, as they were starving. The sun dries up the ponds and they cannot drink nor lay eggs. Vegetation becomes dry and parched, and does not supply nourishment. A few hot days, followed by a wind, and it was predicted they would go. This had come. Donning my coat containing papers, vials, corks, gloves, and other necessary material, and accompanied by my dog, I started for butterflies.

Two or three Arygnnids had been seen, which were very much wanted. Half a dozen other species were on the wing, but all species were doubtful, i. e. could not be named from seeing the specimen flying.

The field sought was the tamarack forest. The beautiful and stately trees filled the slope of the lake near the laboratory. An occasional Douglas spruce or yellow pine added to the charm of the tamarck forest A wagon road wound through the timber, affording a sunny opening in which the insects love to sport. On either side the tall conifers towered heavenward. A breeze was blowing. The murmur of the pines as they swayed gently at their tops was music to the ear. The timber was not dense. The sun filtered through the leaves and between the treetops, making alternate patches of light and shade. In the forest, therefore, it was thought the airy creatures would sport, where the sun's rays were tempered by the shadow of trees, where the breeze would be less likely to blow against their delicate wings, and where they would be unmolested.

The delicate blue bells nodded in the underbrush. Mariposa lilies were on the wane, but an occasional late one showed its delicate cream colored perianth here and there. The twin flower was in bloom, making a carpet where other vegetation was lacking. Service berries were ripe, the blue-black berries hanging in clusters from every bush. Spiraea was gorgeous, just coming into full bloom. A fringe of rock maple, dogwood, spiraea and service berry lined the road, while through the timber they were scattered in great profusion.

It was a day for birds. The brilliant plumage of the Louisiana tanager flashed in the sunshine as he flew from tree to tree. The call of the western Phebe was heard on every side. The long-tailed chichadee cheerily sang from the bushes by the roadside. Upon an old bole a flicker was calling to his mate, and alternately with his call drumming loudly on the dead tree. While sitting on a log and drinking in the sweetness of the bird music mingling with the sighing of the pines the loud call of 
the pileated woodpecker was heard in the distance; for this shy and handsome bird, the largest of our woodpeckers, is still not uncommon in the woods of Montana. I could not mention all the birds seen and heard. One hundred and forty species have been found in this vicinity. On that day the woods were alive with birds, sweet with their melody and with the odor of flowers. It was a walk of solitude, but I was by no means alone.

In a thick cluster of service berry my dog flushed a ruffed grouse with young. The little fellows could fly a little, and would rise into the top of a little birch or alder and pipe their alarm in great consternation. Their

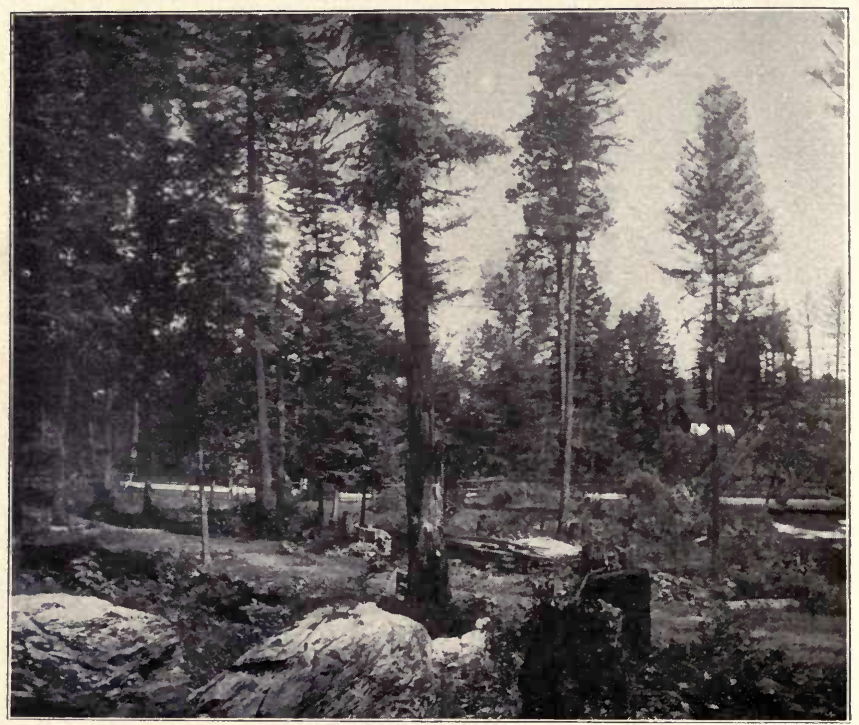

Fig. 85. Where Leto abounds, near the University of Montana Biological Station, upper end of Flathead Lake.

somber coats blended beautifully with the surroundings. If one saw a bird alight it was plainly visible. But when once the eye was turned elsewhere and returned to the spot the motionless bird blended with the light and shadow of the forest and with the bark of the trees. Had the little fellows remained quiet they might have passed unnoticed. They will learn, if some pot hunter does not kill them too early. The mother flutters around and makes a great fuss, while the young are scurrying away to places of safety.

Scarcely had I left the laboratory when a beautiful Eurymus was seen flying over the bushes by the river bank at the entrance to the forest. Occasionally the delicate butterfly was seen, and I longed to have it. 
Carefully I followed until the time was favorable for a sweep, when it was safely landed, much to my delight. Eurymus alexandra is not abundant here, but is often seen sailing gracefully over the tops of the dense bushes, out of reach but aggravatingly near. It was a perfect specimen, the only one seen or taken during the day.

I started before two. Along the road I went slowly, seeking the Argynnids. They were out. Such beautiful and dainty creatures they are. Leto was out in all its glory, but my captures were few. I simply could not do it. I was too awkward, slow, or something. They would not rest. Again and again their course would be near me and I would try, only to fail with an $\mathrm{AH}$, and sigh of regret. Beautiful, dainty, delicate creatures, sporting in the open forest, flitting from open sunshine where the resplendent colors show in all their glory to the shadow of the forest where they may have a little respite. Their gaudy colors make them conspicuous a long distance off, and their large size makes it possible to detect them and distinguish them from others. Of the size of cybele of the east, which was my early delight, it lends a charm to the forest superior in some respects to that given by music of birds or odor of flowers. Gorgeous in array, gentle in movements, short of life, its life nistory unknown, what wonder that it has charm. The day was too hot for Leto to be in the open. I sought, but in vain. A return to the forest brought its company. Its flight is rapid and undulating. Rarely did it rest. Pursuit into the forest beyond the road was impossible because of brush, fallen logs, stumps and stones. Again and again I made a desperate sweep for a dark female or a more brilliant male. Thrice was I successful, but many times did I fail. But one sweep was granted. With the swish of the net through the air it was off in that peculiar zigzag course common to most butterflies, the angles of flight and the lines of flight as sharp and as numerous as the zigzag lines on the wing. It was not so abundant as formerly, for annually it has been taken near the laboratory for five seasons.

Other Argynnids were out. Hesperis and one I took to be atlantis, but which may prove to be different, were on the wing. The time to take pie is when it is passing. The time to take butterflies is when they are to be had. There is no more fatal error than to fail to take specimens because they are plentiful. They may not be so to-morrow. Every naturalist will no doubt recall irreparable losses because he failed to take specimens when they were to be had, but delayed for a more convenint season.

Atlantis was abundant. It is not so large nor so gorgeous as Leto, but is nevertheless beautiful. The underside of the species captured is dark buff with a slight submarginal band. It was abundant. It seemed to be especially fond of resting on Spiraca lucida. It rested often, and was not difficult to capture. The afternoon's catch resulted in 23 specimens of this and Hesperis. Atlantis was frequently interrupted in its rest on Spiraea lucida by Phyciodes tharos. Whenever a tharos was near it would invariably fly to the atlantis on the shrub. They would arise together and circle about before separating. Frequently the two were taken together. Tharos was invariably the aggressor. Whether it 
dislikes Atlantis or not was not apparent. It appeared more a curiosity move, but was not displayed toward the others.

Phyciodes tharos was abundant, and had been several days. Light, graceful and delicate, it rested airily on the broad white umbels of the Spiraca, when it would spread its wings to their fullest extênt and fan them gently up and down. Its flight is more graceful and undulating than that of the Argynnids. It moves more slowly, keeps in the open, and for that reason was not difficult to capture. It was taken while waiting for others to appear.

Lycaona meliasa, the orange-margined blue, was less abundant along the roadside than on former days. It is a delicate little butterfly of wondrous beauty in color. It expands only about an inch. The males are blue-violet above with a delicate fringe or border of white scales to the wings. The female is dark brown with eye spots on the wing margins, surrounded by orange, giving the appearance of an orange band. It is underneath that the gorgeous colors appear. The spots with their border of gold and dust of silver, on a light grey background, and set out in contrast to the pure white brush like margin, call for admiration from all. Along the roadside they slowly flitted, mostly males, but now and then a female, occasionally seeming to hobnob with tharos, but always in graceful contrast to the more swiftly moving Argynnids. They were easy to take, but previously many had been captured.

A single Lorquin's admiral Basilachia Iorquina, was captured as it was being gently wafted along a side road by the breeze.

Down among the red cedars along the rocky lake shore a female Parnassius smintheus was resting on a weed. She was royal in her array of delicate red, creamy white and drab gray. Upon the hilltop one must usually search for smintheus, for it is an alpine species, among the rocky summits where grow the sedum and saxifrages. It is rather suprising to find it at the level of the lake, about 2,900 feet, yet on several previous occasions it has been seen and captured.

Shortly after four in the afternon the trees were casting longer shadows, and already the cool of evening was being felt in the woods. The sun in the insects' god. When it shines all is life and activity. The whirr of the bettle's wings is heard, and the bumble bee hums from flower to flower, flies and gnats fill the air, dragonflies and damselfiles skim the surface of the water, and butterflies disport themselves on airy wing. But when a passing cloud obscures the sun, or evening approaches, every form of insect life, except the mosquito and gnats, seems to feel the depression, and goes to cover. Where or what the cover is, who can tell? Two hours of brief collecting, and the work of the afternoon was over. The net result was forty butterflies and two moths, embracing the following species: Colias alexandra, Argynnis atlantis, abundant; Argynnis leto, less common; Lycaena melissa, quite common; Phyciodes tharos, common; Basilarchia lorquina, a single specimen; Parnassius sminthcus, a single specimen; Argynnis hesperis, rare; a small black butterfly, of undeterminable species, two specimens; total, forty specimens, eight species.

This was a good day. Many and many a day in Montana has resulted in a third of this catch. Both species and specimens are lacking in 


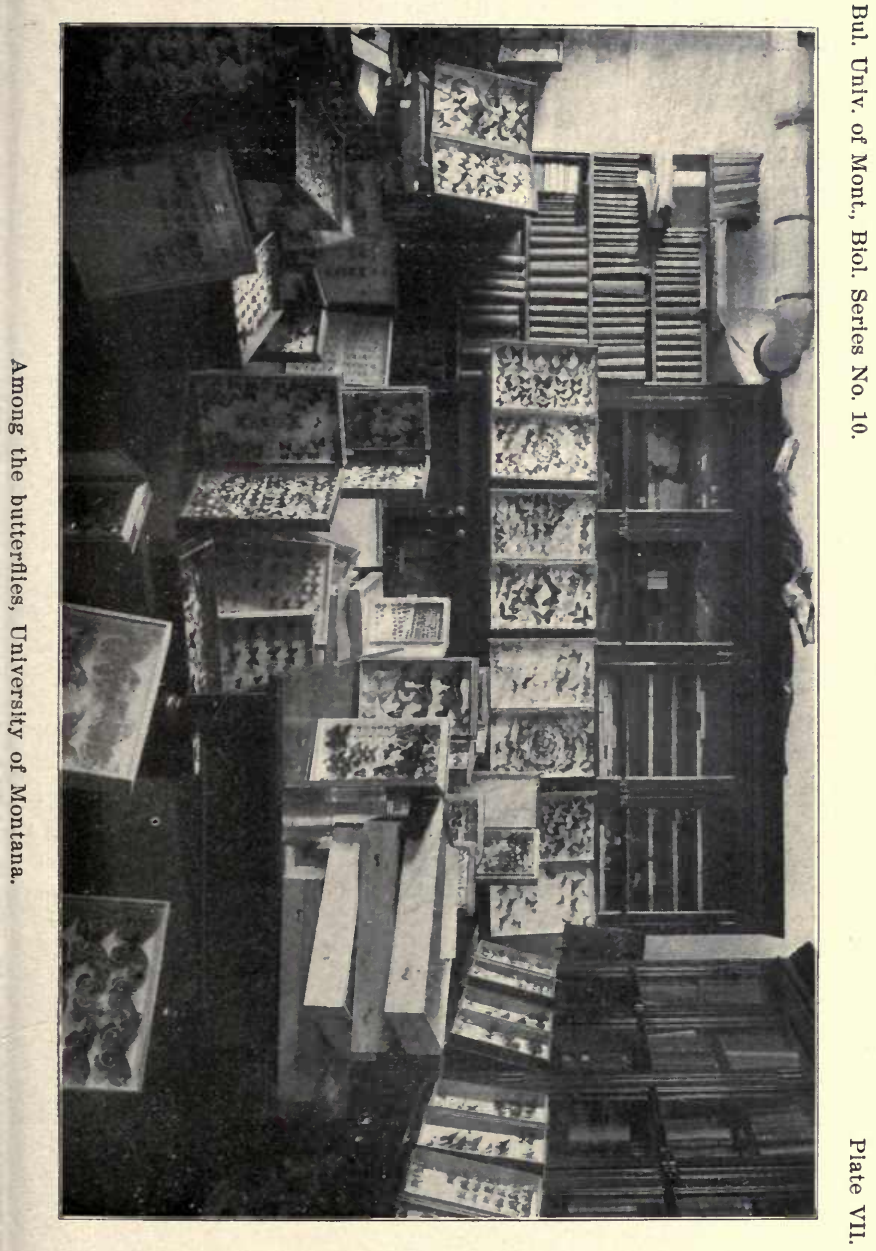





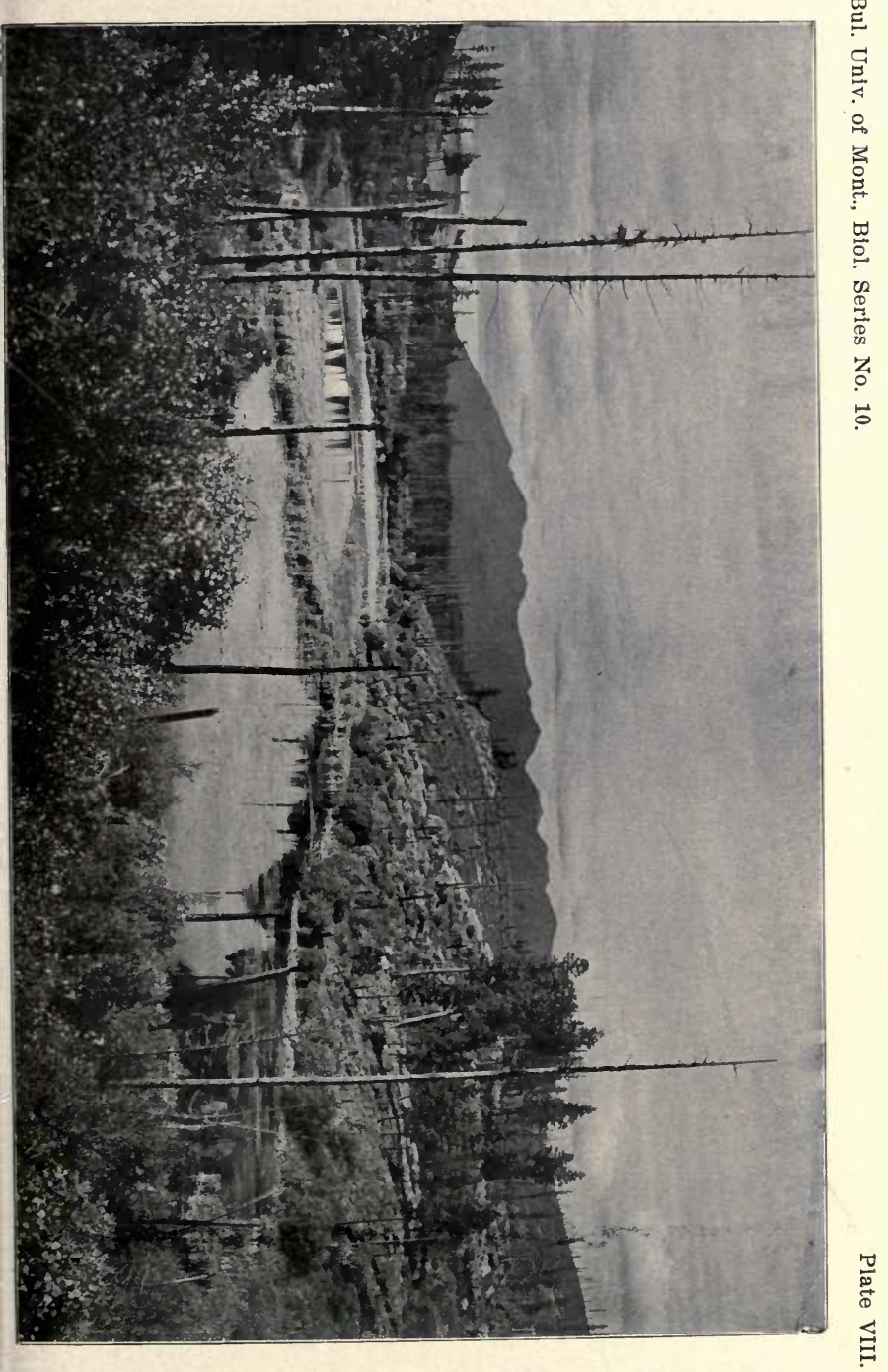





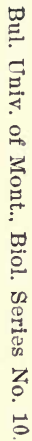

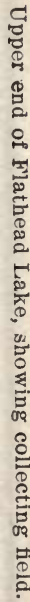

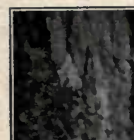

ary

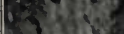

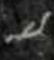

Antis

Now
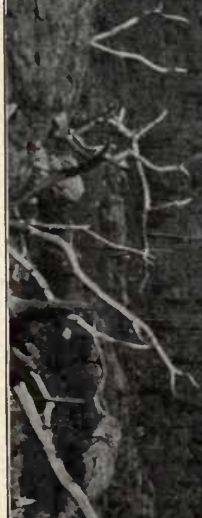

find

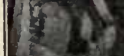

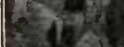

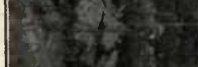

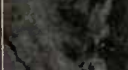

X. 4

(1)
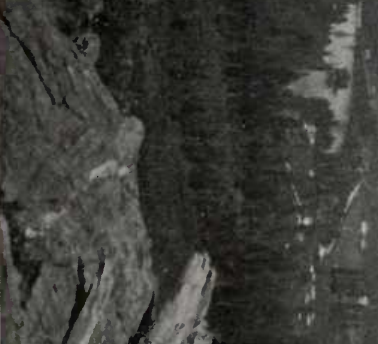

$\frac{7}{\sqrt[0]{0}}$ 

numbers as compared with collecting in my boyhood days, when I used to pick them up on the common or in the clover meadows in much greater numbers.

The next afternoon I tried again. The sky was obscured by light fleecy summer clouds, which later thickened for rain. Atlantis was some place else, and but a few were seen. Leto was very scarce, not one captured. Melissa was yet in numbers, largely females whereas the catch of the previous day was largely of males. Tharos was still in evidence. A single Satyrus olympus was added to the collection. Not a smintheus was in sight, not an admiral. A male Colias alexandra hastened from the road to the bushes and eluded capture. It was a close day but a poor catch.

The above is typical of good days in Western Montana. Wylie complains bitterly of the scarcity of butterfies in the eastern end. And yet the chase is not without its charm and its reward. The fleld is new, The unknown species lends zest to the search. "It isn't this not that, it must be something new," is interesting and cheerful to hear. It shows the speaker is thinking. And the great state, with its wealth of life, beckons to the ambitious entomologist who may be the first in his locality, offering him a rich if not prolific field. To the collector will come a love for the woods and fields. They will not be places of solitude, for there he will find friends, and will commune with nature in that manner which brings the richest reward, when he is alone. He will feel the thrill of joy at first holding in his grasp a new find, for new they must be for years yet. His will be the pleasure, perhaps, of finding something new about some abundant species, for "Unknown" is yet written after many species herein mentioned. Nay, perhaps his small collection may be the humble beginning of a larger work, leading to broad fields and to the fascination whlch comes to him whose horizon is broad, widening with each day's work, limited only by physical limitations. Love for the humble little creatures of the air, love for the beautiful in nature, as revealed in their rich ornamentations, love for nature itself, with a reaction upon the individual, making him more appreciative, more happy, and more contented, will be the final reward of the young collector.

Bigfork, Mont., July 23, 1903.

M. J. E. 


\section{Genus EREBIA, Dalman. \\ "The Alpines." \\ Key to Species.}

Wings dark brown, ocelli pupiled with white and surrounded with red.

epipsodea.

THE COMMON ALPINE, Erebia epipsodea, Butler.

Fig. $86,87$.

Butterfly-The wings are dark brown, almost black, pupiled with white, and broadly surrounded with red near the outer margin of the fore wings, and with three or four ocelli on the upper side of the aind wings. The spots on the upper side reappear on the under side, and in
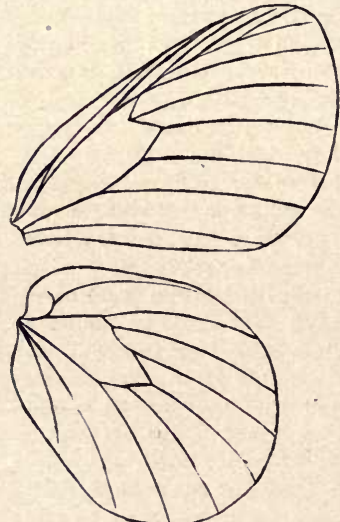

Fig. 86. Venation of Erebla epipsodea

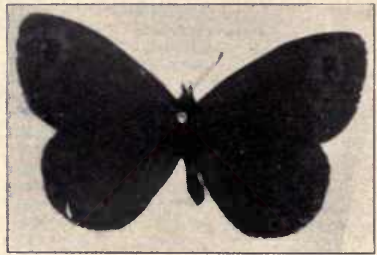

Fig. 88. Erebia epipsodea, lower surface. addition the hind wings are covered by a broad, curved, median blackish band.

Early Stages-The caterpillar feeds on grasses.

Distribution-It ranges from New Mexico (at high elevations) northward to Alaska. It is common on the mountains of British Columbia. The collection in the University of Montana contains specimens from Sinyaleamin lake and McDonald lake in the Mission Mountains, Flathead Indian Reservation, the Tobacco Root range, Geyser Basin and Missoula.

It has been collected by Brandegee at Helena, and reported common. It has been taken by Cooley at East Flathead in Park county, at Shields river, Park county, at elevation 6,400 feet, at Mystic lake, Gallatin county, at 6,700 feet, and at Bozeman.

This butterfly is one of the early spring insects. The earliest about Missoula are Aglais milberti and Eugonia californica. Before the hot days come on Erebia epipsodea seems to be at its best. The last of May and the first days of June are the times when it is at its best. Its flight is like Cercyon, and the species is easily recognized by its flight. 


\section{Genus COENONYMPHA, Westwood.}

The Ringlets.

Small Butterflies. The costal, median and sub-median veins are all strongly swollen, as may be seen in figure 89 . The palpl are very heavily clothed with hairs, the last joint quite long and porrect. The antennae
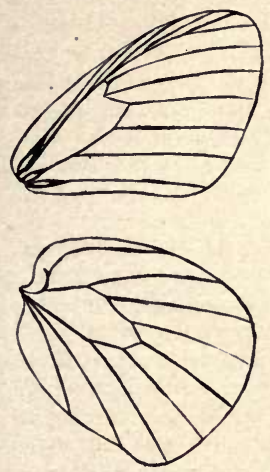

Fig. 89. Venation of Cononympha. are short, delicate, gradually but distinctly clubbed. The eyes are naked. Both wings on the outer margin are evenly rounded.

This genus is distributed throughout the temperate regions both of the old and new world, and includes in our fauna a number of forms, the most of which are peculiar to the Pacific coast. They are very variable as to the number of spots and ocelli, and vary greatly in the color of the under side. It is no infrequent thing to find the ocelli and spots differing on the two sides of the same insect.

Key to species.

Upper side bright glossy ochre-yellow; no markings above save by the transparency of the wings ochracea

Upper side fuscous, immaculate; under side a shade paler, much irrorated with gray scales.

Upper side pale ochre-yellow, immaculate haydeni elko Upper side ochrey-brown, lighter in the disk of all wings.

THE OCHRE RINGLET. Coenonympha ochracea, Edwards. Figs. 90 and 91 .

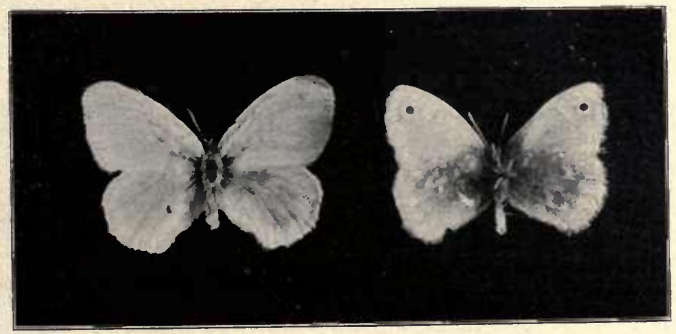

Figs. 90 and 91 , upper and lower surfaces of Coenonympha ochracea.

the hind margin; abdominal margin and base dark gray; near the hind margin and parallel to it is a series of six black dots, sometimes obsolete, usually with white pupil and broad yellow iris; near the base two irregular pale brown spots, and midway between the base and hind margin a sinuous interrupted ray of same color, extending nearly across the wing. Female like the male.

Early Stages-Unknown. 
Distribution-Ochracea has a wide range, from Lake Winnipeg in British Columbia to Kansas and west to California.

This dainty little insect is abundant about Missoula in early spring. In May and early June it sports along the open hillsides, being most abundant in mountain gullies where moisture lingers, or along the banks of streams.

The university collection embraces specimens from McDonald lake in the Mission Mountains, Missoula, New Chicago, the Tobacco Root range, and the Ruby Mountains. It is common about Helena according to Brandegee. Wiley has it in his collection from Miles City, and Cooley has collected it at Forsyth and Bozeman. Coubeaux reports it moderately common in Bear Paw Mountains. Coues collected it along the 49th parallel in 1874 .

Remarks:-Dr. Henry Skinner, in his revision of the American species of the genus Coenonumpha, Trans. Amer. Ent. Soc., Vol. XXVI, says of this species: "That is quite a variable species. The upper side differs very much in different specimens in regard to the distinctness with which the spots below show through on the upper side. The color of this species, in conjunction with the distinct ocellus on the premaries below, serve to distinguish it from all others." He calls C. brenda Edwards a synonym of C. ochracea, and says it is only a much spotted ochracea. "If we give names to all the variations of ochracea we would have six names for the species."

\section{THE RINGLESS RINGLET. Coenonympha elko, Edwards.}

Butterfly, Maie-Expanse, .95 to $1.00 \mathrm{inch}, 25 \mathrm{~mm}$.

Upper side pale ochre-yellow, immaculate; fringes concolored. Upper side of primaries nearly same ochre-yellow over basal area and part of disk, limited without by a slightly sinuous and crenated edge of deeper color, much as in the allied species; outside this, slightly ochraceous next the inner angle, but yellow-buff over apical area. The secondaries have the basal area uniform grey-brown, the outline distinct and in strong contrast with the remainder of the wing which is yellow-buff. Very slightly gray; the outline is irregularly crenated, with a deep sinus on the upper sub-costal interspace, and another on the lower disco-cellular interspace.

Female-Expands 1.00 to 1.02 inches. Upper side like the male. Beneath, the area just outside the crenated edging on disk of primaries is yellow for a little distance, then tinted ochraceous to the margin, in one example a minute black dot in the disco-cellular interspace with white center, in another no dot; secondaries as in male, basal area one shade of gray, with distinct crenated outline, and beyond a yellow or buff ground to the margin, very little dusted with gray.

Distribution-It occurs in Vancouver's Island, Washington, Oregon, Nevada, Montana, Utah and Idaho.

Remarks:- Very much like ochracea, but it is distinguished from others by the absence of ocelll on both wings, above and below. According to Edwards ampelos and elko are same. He has found two specimens with spots on the secondaries.

THE PLAIN RINGLET, Coenonymph tiphon, var. laidon, Borkh.

Butterfly-This hutterfly was described by Edwards as C. inornata Dr. Buckell called attention to its resemblance to the European form. His view is confirmed by Dr. Skinner in his recent paper previously referred to. The following is Edwards' description of inornata, and therefore of laidon. 
Male-Expanse, $1.40 \mathrm{inch}, 35 \mathrm{~mm}$. Upper side ochrey-brown, lighter in the disk of all wings; costal margin of primaries and abdominal margins of secondaries grayish, no spots above or below; fringe gray, crossed by darker lines. Under side: primaries same color as above, from base to beyond the middle, then a transverse sinuous ray of paler color, and beyond this to hind margin grayish; sometimes this ray disappears, the basal color extending nearly to the apex; secondaries gray, with a slight grayish tinge, darker from base to middle, and this shade separated from the paler margin by a transverse tortuous interrupted ray, the course of which is parallel to the hind margin.

Female-Wholly dull ochrey-yellow, marked as in the male.

Dr. Skinner adds: "This species is readily distinguished by its rich dark color, being the darkest of all the species except haydeni. Likeall the other species it has ocelli. Mr. Edwards' specimens were evidently devoid of ocelli, as he says "No spots above or below."

Distribution-The species occurs in Montana, Minnesota, British America and Newfoundland. Examinations show the collections to have, one from Mount Lo Lo by Elrod and one from Miles City by Wiley. Collected by Coues in the mountains along the northern border in 1874 .

HAYDEN'S RINGLET, Coenonympha h:ydeni, Eduarís. Fig 92.

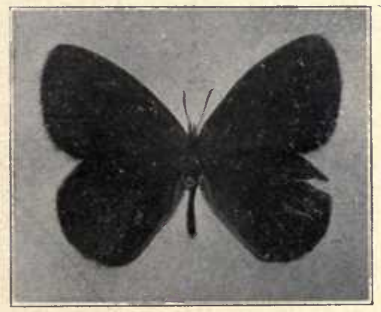

Fig. 92. Coenonympha haydeni.

Butterfly, Male-Upper side entirely of a bright glossy ochre-yellow, without any spot or mark, except what is caused by the transparency of the wings; base of both wings dark grey; abdominal margin of secondaries pale gray; fringe pale gray, crossed by a darker line. Under side. Primaries same color as above; costal margin, apex and base grayish; near the apex a round, sometimes a rounded-oblong, black spot with white pupil and pale yellow iris; this is preceded by an abbreviated, pale yellow, transverse ray. Secondaries light reddish brown, grayish along

Butterfly, Male-Expanse, 1.60-inches, $40 \mathrm{~mm}$. Upper side fuscous, immaculate; under side a shade paler, much irrorated with gray scales; primaries immaculate; secondaries have a complete series of black ocelli along the hind margin, one in each interspace; each ocellus narrowly ringed with ochraceous, and having a minute white pupil.

The female is like the male in markings, but in color quite different, as it is light yellowish-brown.

Distribution-The species has been found in Montana, Idaho, Colorado and Wyoming. The University of Montana has but one specimen at present writing, collected by Douglas in the Tobacco Root range. Cooley has taken it at Mystic lake, 6,700 feet elevation, in Bridger canyon, along Shield's River, at East Flathead in Park county, and at Bozeman. 
List of Butterfiles taken by H. R. Morrison in Dakota and Montana, 1881.

1. Papilio zolicaon, Bois.

2. Pontia (Pieris) protodice, Bois.

3. Eurymus (Colias) philodice, Godart.

4. Eurymus (Colias) eurytheme, form keewaydin, Edw.

5. Argynnis cybele, Fab.

6. Argynnis aphrodite, Fab.

7. Argynnis nevadensis, Edw.

8. Argynnis Edwardsii, Reak.

9. Brenthis (Argynnis) myrina, Cram

10. Euptoieta claudia, Cram.

11. Lemonias (Melitea) acastus, Edw.

12. Phyciodes carlota, Reak.

13. Phyciodes tharos, Drury.

14. Basilarchia (Limenitis) wiedemeyerii, Edw.

15. Pasilarchia (Limenitis) disippus, Godt.

16. Coenonympha tiphon, var. laidon Bork (inornata Edw.)

17. Cercyonis (Satyrus) alope, var. nephele, Kirby.

(nephele, var. olympus, Edw.)

18. Cercyonis (Satyrus) meadii, Edw.

19. Cercyonis (Satyrus) sylvestris, var. Charon, Edw, (charon).

20. Cercyonis (Satyrus) sylvestris, Edw.

21. Oeneas (Chionobas) varuna, Edw.

22. Uranotes (Thecla) melinus (humuli).

23. Thecla liparops, Bois \& Le Conte, (strigosa, Harr).

24. Thecla acadica, Edw.

25. Mitoura (Thec'a) damon, Cramer, (smilacis, Bois).

26. Gaeides (Chrysophanus) dione, Scudder.

27. Epidemia (Chrysophanus) helloides, Bois.

28. Chalceria (Chrysophanus) rubidus, Edw.

29. Cupido (Lycaena) saepiolus, Bois.

30. Rusticus shasta Edw., (Lycaena lupini, Bois.)

31. Rusticus (Lycaena) melissa, Edw.

32. Rusticus (Lycaena) acmon, West.-Doub.

33. Cyaniris (Lycaena) ladon, Cramer (pseudargiolus, Bois.)

34. Cyaniris (Lycaena) ladon (pseudargiolus), form violacea, Edw.

35. Everes (Lycaena) comyntas, Godt.

36. Pholisora (Ancyloxypha) lena, Edw.

37. Oarisma (Thymelicus) poweschiek, Parker.

38. Errynnis (Pamphila) pawnee, Dodge.

39. Erynnis (Pamphila) uncas, Edw.

40. Limochroes (Pamphila) manataaqua, Scudder (cernes, Harris.)

41. Euphyes (Pamphila) vestries, Bois, var. metacomet, Harr. (metacomet, Harr.) 
42. Phycanassa (Pamphila) vitellus, Fab. (delaware, Edw.)

43. Ambliscirtes vialis, Edw.

44. Pyrgus montivaga, Reak. (tesselata, Scud.)

45. Scelothrix (Pprgus) scriptura, Bois.

46. Thanaos perseus, Scudder.

This list of 46 species is given by W. H. Edwards in the Canadian Entomologist, Vol. XIV, p. 6, 1882. As here given the nomenclature used in this work has been used. Where the names used by Edwards are different from those used in this book they follow immediately and without commas, in parentheses. Where parentheses do not occur the Edwards names and names used by us are the same.

From this list it is impossible to tell which specimens were collected in Montana and which in Dakota. The species which are not included in this work are Nos. $20,25,26,41,42$, aud 43 . Whether these are to be included in the lost from Montana is yet to be determined.

\section{Genus OENEAS HUEBNER.}

\section{The Arctics.}

Butterfly-The antennae are short, the eyes of moderate size; The front full, protuberant; the palpi slender; the fore wing somewhat produced at the tip; with the outer margins rounded and the hind margins slightly, if at all, sinuated. The nervules of the fore wings are slightly dilated toward the base; the hind wings are elongated, oval, and the outer margins evenly rounded. The color of these butterflies is some shade of brown; the outer margin is generally lighter than the base of the wing, and is marked with black spots, sometimes pupiled with white. The wings are generally marbled and mottled on the under side, and sometimes crossed on the middle of the hind wings by a broad band of darker color. The fringes are brown, checkered with white. The eggs are ovate, spherical, marked with sculptured ridges. The caterpillars are pale green or brown, marked by darker stripes upon the back and on the sides. The chrysalids are stout, very slightly angulated, and are formed, so far as we know, unattached under stones and at the roots of grasses.

The genus contains insects belonging to the Arctic fauna, which are formed in the far north or dwell upon the lofty mountain summits where the season is short. Of the large number of species formerly recognized but seven are retained, the others being placed as sib-species or varieties. At the present time but two are recorded from the state, although we should expect nevadensis, and possibly macounii.

Key to species.

Dark brown color, covering basal and median areas; a broad band of lighter shade on outer margin; under side mottled with white and brown. chryxus

Smaller, lighter in color; under side mottled with brown and black 
THE CHRYXUS BUTTERFLY. Oeneas chryxus, Westwood. Plate $X$. also Plate 1.

Butterfly-Expanse, 1.75 to 2.25 inches, 44 to $57 \mathrm{~mm}$. Light brown above, usually with darker color on the basal and median areas of both fore and hind wings, leaving a broad band of lighter color. A narrow dark brown or brownish black outer margin on both pairs of wings. Outer edges fringed with dashes or crescents. Edge of costa usually mottled. Wings on under side beautifully mottled with white and dark brown, a heavier band of almost black crossing both wings near the center, making an acute angle toward outer edge near the middle of fore wing. One to several eye spots, some pupiled with white, which show above as dark brown or black. The plate shows some of the variations of the species.

Distribution-The insect is found over a wide territory, from Hudson Bay and British Columbia to Colorado, the light colored variety invalida in Nevada and California. It has been taken in the state by Cooley in Gallatin county at 9,400 feet, and at Missoula; by Brandegee at Rimini near Helena and at Cascade on the Missouri river; Douglas collected it in the Tobacco Root range; Elrod has specimens from Missoula, from Mount Lo Lo, from Geyser Basin in the Yellowstone Park, and from the Swan range. The species is alpine. It has not been taken below 5,000 feet at Missoula, and above this is quite common. It has frequently been seen in the Swan range above 6,000 feet.

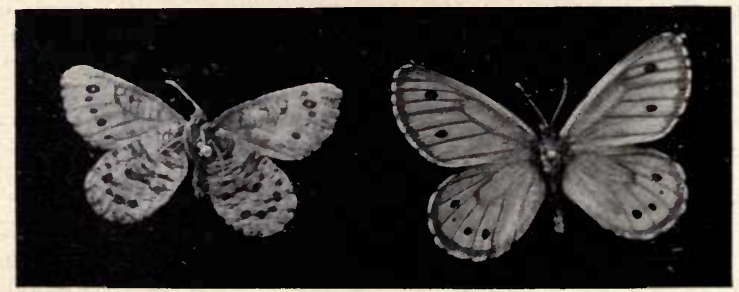

Fig. 92A. Oeneas uhleri, var. varuna; lower surface on left, upper surface on right; natural size.

THE VARUNA ARCTIr. Oeneas uhleri Reakirt, var. varuna, Edwards.

Butterfly-Expanse, 1.50 to 1.75 inches, 38 to $45 \mathrm{~mm}$. The butterfly is among the smallest of the Oeneas group. It is light tan colored above, with a narrow dark grown border on both wings. Edges with light fringe, broken by the brown. On the under surface the wings are mottled with brown, strongly marked with blackish blotches or shades. Usually several (two to five) eye spots, black, mostly pupiled with white, which show through as black.

Early Stages-Fully described by Edwards in Volume III of his great work "The Butterflies of North America." Eggs chalk-white, conical, truncated, ribbed. Mature larva .90 to .94 inches long, stout, thickest at the middle, a lateral band and several stripes of black, the intervening bands solid green. Under side, feet and logs, green, with a tint of brown. Chrysalis about .50 inch long, greenish yellow, wing cases 


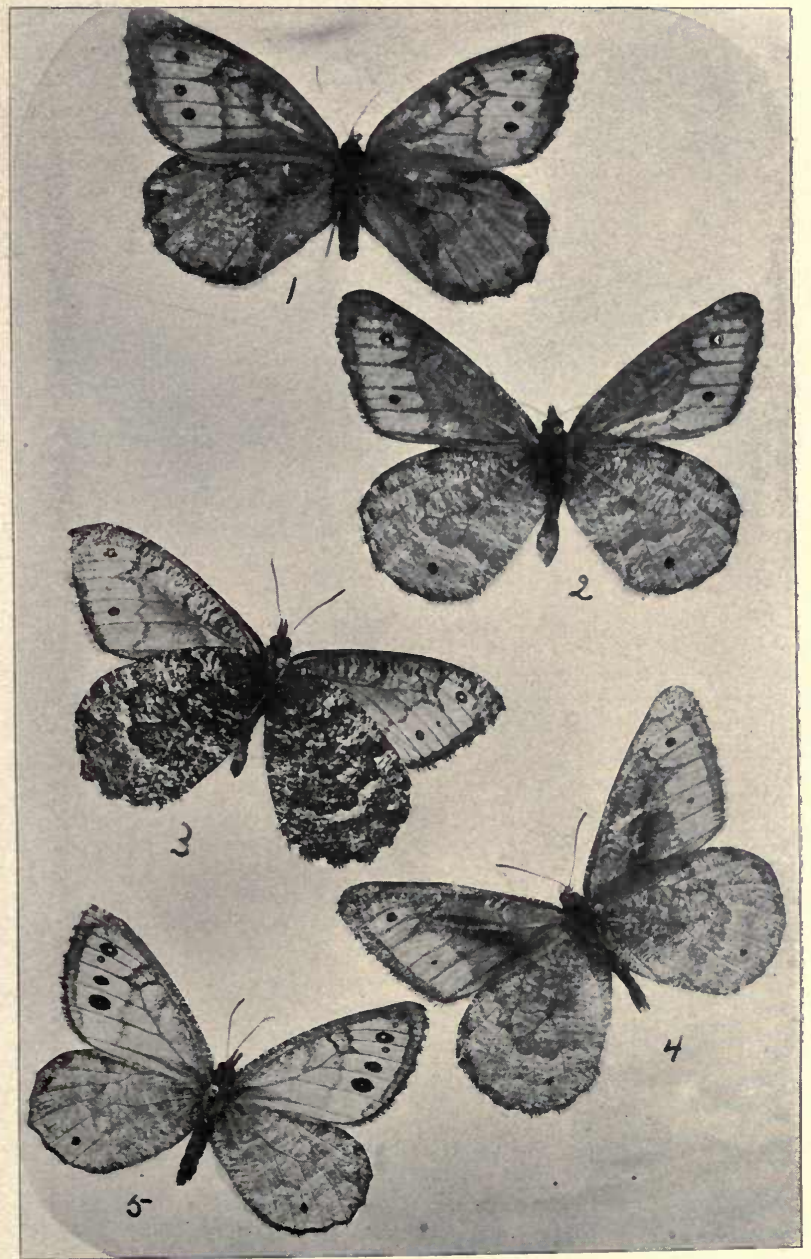

Oenas chryxus, showing yarious forms of wing coloration. Nc. 3 is lower surface. 

wlth a shade of brown, head and abdomen wit's still more brown. Larval period, eleven to twenty days, pupal period about eleven days.

Distribution-It is found in the prairie lands of North Dakota, and the parts of Montana and Canada adjacent. It is not uncommon about Calgary. Wiley has collected many specimens around Miles City, and in 1894 sent eggs to Edwards to be hatched. Cooley has collected it at Bozeman. Taken by Coubeaux in Bear Paw Mountains.

Genus NEOMINOIS, Scudder.

RIDINGS SATYR, Neominois ridingsii, Edwards.

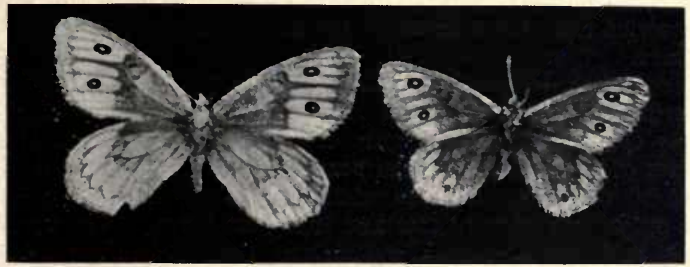

Fig. 92B. Neominois ridingsii, natural size.

Butterfly-Expanse, Male, 1.6 to 1.8 inches, Female, 1.8 to 2 inches. Upper side dusky gray-brown, pale over the basal areas, beyond to margin dark; a common extra-discal series of buff spots, on primaries separated in the lower discoidal interspace; the four above this confluent, their outer extremities lanceolate, and being on the upper discoidal interspace a white pupiled black ocellus; the fifth spot is long, oval, narrower than the interspace - the upper median; the sixth is suboval, broad, and carries a second ocellus, usually equal to, but sometimes a little smaller than the other; the next two spots are sometimes completely confluent, and are about half the length of the sixth; on secondaries the spots from a continuous band of nearly even width, the upper three more or less incised on the basal side; the outer ends serrate, or partly lanceolate; a small black patch near the outer edge of the spot in lower median interspace; occasionally a minute pupiled ocellus is present on the lower sub-costal interspace of primaries, outside the line of the principal ocelli; fringes fuscous, yellowish at the tip of the nervules.

Under side paler; the cell of primaries and the basal and marginal areas of both wings covered with fine abbreviated dark streaks; the spots and ocelli of primaries repeated; the buff band of secondaries rarely clearly repeated, but the position of the outer edge of it is indicated by a black serrated line; the marginal inscriptions usually extend across this line well toward the mesial band; this band is closely as in the allied genus Oeneas, light within, dark near and along both edges; the elbow without rectangular on the lower discoidal interspace, with equal serrations from the angle to costa (though sometimes the lower two are much prolonged, acuminate); on the basal side a small angular sinus on the sub-costal nervure, and a large rectangular, or sometimes rounded, projection on the median. 
Body dusky gray-brown; beneath light and concolored with the wings; femora light grey, the tibiae red-brown; palpi whitish, with many black frontal hairs; antennae fuscous above, cretaceous below; club red-brown beneath and at the tip.

The female is very much like the male; some individuals have a small ocellus on the upper median interspace.

A late form is a little larger, than the other, paler colored, especially beneath, where the inscriptions are faint and the space which on the upper side is occupied by the buff band is scarcely outlined; the mesial band but a shade darker than the basal area.

The above lengthy description is taken was reported after the manuscript for this work was completed and the cuts made.

Early Stages-The egg is sub-conic, base and top flattened, marked by nineteen and twenty vertical ribs; color chalk-white. The mature larva is about an inch in length, covered thickly with small pointed tubercles of irregular sizes, each bearing a rather long, clubbed and appressed whitish process; color reddish buff, the sides pale green; middorsal stripe pale black; feet and legs gray-green. The chrysalis is about a half inch in length, cylindrical; color red-brown, darkest anteriorly, the divisions of the abdomen green; wing cases green, around the margin brown. Pupation takes place under the ground.

Distribution-It is reported from tne Mountain states of the Pacific coast. In Montana it has been collected by Cooley at Bozeman and by Coubeaux at Big Sandy. 


\section{EXCHANGES.}

One of the best ways of adding to a collection is by the method known as exchanging. A collector in one part of the country may find species which are rare, or altogether unknown, in another part of the country. By a system of exchanges with other collectors he is able to supply the gaps which may exist in his collection. No one, however, cares to effect exchanges with collectors who are carless or slovenly in the preparation of their specimens, or inaccurate in naming them. A collector who contemplates making an exchange should, as the first step, prepare double lists, in one of which he gives the names and the number of specimens of either sex of the butterflies which he is able to offer in exchange; in the other he sets forth the things which he desires to obtain. The first list is sald to be a list of "offerta"; the second is a list of "desiderata." As an illustration of the manner in which sucl lists may be conveniently arranged, I give the following:

\section{Offerta.}

Papilio turnus-Male three; female four. Dimorphic var. glaucus, male six. Colias alexandra, male four; female six.

\section{Desiderata.}

Papilio nitra, female.

Papilio brevicauda, orange-spotted var.

The collector who receives these lists of offerta and disiderata will be able to decide what his correspondent has which he desires, and what there may be in his own collection which the correspondent wishes that he can offer in exchange ; and the process of exchange is thus immediately facilitated.

Persons who exchange insects with others should always be extremely careful as to the manner of packing the specimens. Too much care cannot be taken in preventing damage to specimens in transit.

Holland, in "The Butterfly Book." 


\section{Family LYCAENIDAE.}

The Gossamar-winged Butterflies, the Blues and Coppers. Fig. 93.
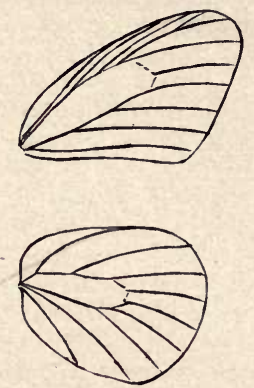

Fig. 93. Venation of Rusticus melissa.

The family includes butterflies of small size and delicate structure. They are easily distinguished from the skippers. The body is slender, the wings delicate and often brigntly colored, and the club of the antennae straight. The antennae are nearly always ringed with white, and a conspicuous rim of white scales encircles the eyes. The radius of the fore wings is three or four branched.

The blues can be distinguished from the metal-marks by the absence of the costal and humeral veins of the hind wings.

In the female the front legs are like the other legs, in the male they are shorter, without tarsal claws, and with the tarsi more or less aborted.

The caterpillars are slug-like. The body is short and broad, the legs and prolegs are short and small, allowing the body to be closely pressed to the object upon which the insect is moving-in fact some of the species glide rather than creep. Some of the species are remarkable for having honey-tubes which can be pushed out from the seventh and eighth abdominal segments, and through which honey-dew is excreted for the use of ants.

The chrysalids are short, broad, ovate, without angulations. They are attached by the candal end, by a loop passing over the body near its middle.

There are three well marked groups, which have been distinguished as the hair-streaks, the coppers, and the blues.

\section{Key to Species.}

1. Radius of the front wings four branched, wings blue or copper color 7 .

Radius of the fore wings only three branched, under side of wings with hair like streaks

2. Hind wings with a long, slender, tail-like prolongation 
3. Upper surface of wings conspicuously marked with blue scales Upper surface of wings with but few if any blue scales

4.

4. Lower surface of hind wings bright green marked with brown and white

Lower surface of hind wings not green

Mitoura P.

5.

5. Lower surface of wings with a narrow white-edged bar at end of discal cell

Without bar at end of discal cell

6. Under side of hind wings without a row of orange spots

Thecla, P. 127

Uranotus, P. 126

Incisalia, P. 130

Under side of hind wings with a row of orange spots Stryman, P. 131 Under side of hind wings pale fawn, with a row of red spots

Under side of hind wings green

Erora, P. 131

Callophrys, P. 130

7. Color above orange red with a coppery luster, or brown with a coppery tinge, in each case spotted with black

Color above blue or bluish black

10.

8. Hind wings with a broad orange-red band on the outer margin extending from the anal angle nearly to the apex

Hind wings with a sinuous submarginal orange line beginning at the anal angle and fading out near the midale of the outer margin

Epidemia, P. 133

Heodes, P. 134

Gaeides, P. 133

9. Fore wings fulvous, hind wings brown

Both wings brown

Wings under side front wings orange hind wings gray Chalceria, P. 134
tvings under side front wings orange hind wings gray Chrysophanus

10. Hind wings with a slender tail like prolongation Everes, P. 139 Hind wings without tails

11. Under side fore and hind wings similar

12. Under side of secondaries pale gray with white spots Agriades, P. 136 Under side gray, with spots pupiled with black

13. Hind wings with golden or orange spots

Cupido, P. 135

Rusticus, P. 137

Hind wings without golden or orange spots

14. Lower surface of wings slate brown

Lower surface of wings pale ash gray

Nomiades, P. 136

Cyaniris, P. 138 


\section{THE GRAY HAIR-STREAK or MELINUS BUTTERFLY, Uranotes melinus} Figs. 94, 1, and 2.

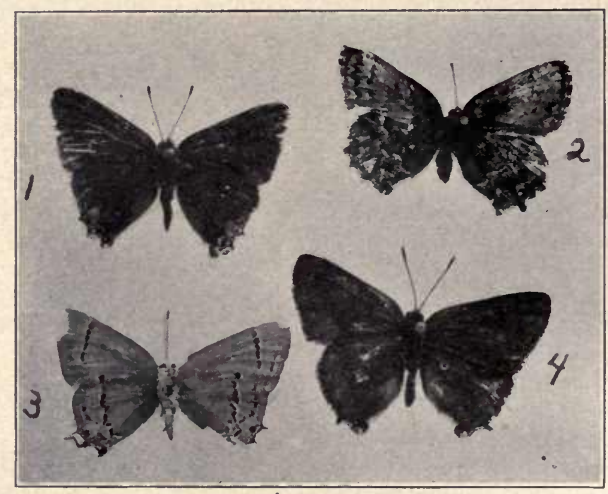

Fig. 94. Uranotes melinus; 1 , upper; 2, lower slde; 3 , Incisalia eryphon; 4, Thecla saepium.

Butterfly-Expanse, 1.10 to 1.20 inches, 28 to $30 \mathrm{~mm}$. This butterfly is easily recognized by its slaty upper surface, adorned by a large black spot, crowned with crimson, between tne orlgin of the two tails of the secondaries. Along the outer margin is a series of more or less distinct pale blue spots. An orange spot at the anal angle: Two slender tails. Under side gray, two black lines crossing both wings, the inner on the hind wings forming a W. The other spots repeated on the under side.

Early Stages-The larvae are "green, downy caterpillars," feeding on the common hop vine.

Distribution-Found all over temperate North America, ranging southward into Mexico, at suitable elevations. It has not been found abundantly in the state. Three specimens have been taken at Missoula. It has been taken at the University of Montana Biological Station at Flathead lake, but is not plentiful. Wiley has one specimen from Miles City. 


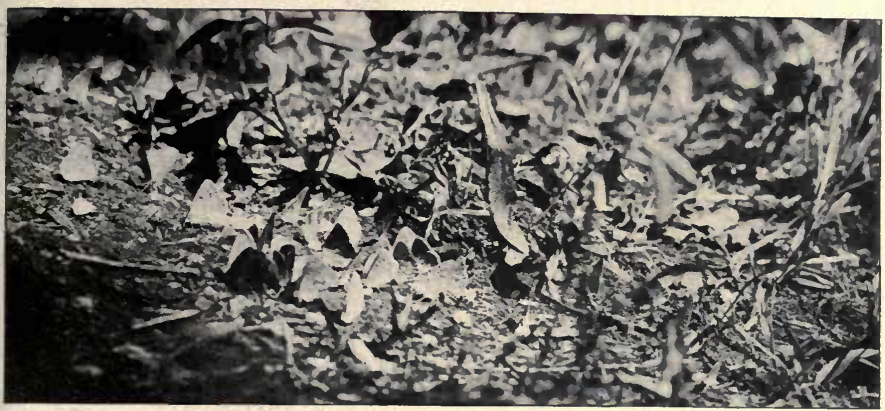

Fig. 95. Lycaena on the banks of Sinyaleamin Lake, Mission Mountains, Mountains.

Genus THECLA. Fig. 96.

Key to Species.
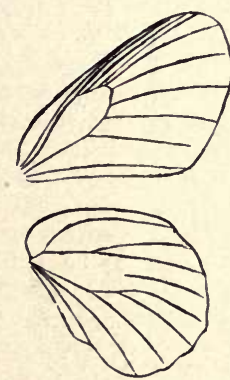

Fig. 96. Venation of Thecla.

Lower surface of wings with a narrow white-edged bar at the end of the discal cell

acadica

Lower surface of wings crossed just outside of the middle by a row of small, dark, blue-edged spots, which form an almost continuous line

calanus

The spots of the extra mesial row of the lower surface of the wings wide and discontinuous

liparops

Lines of spots on the lawer surface narrowly defined externally by white

saepium

THE HEDGE-ROW HAIR-STREAK, Thecla saepium Boisduval, Fig. 94. Butterfly-Exanse, 1.20 inches, $30 \mathrm{~mm}$.

Upper side quite uniformly reddish brown, paler on the under side; a narrow submarginal and an irregular median transverse band, 
narrowly defined externally by white; a well defined black spot at the anal angle of the secondaries.

Early Stages-Unknown.

Distribution-Found throughout the Pacific states, in Montana and Colorado. Holland thinks it identical with chalcis. Taken in the state at Missoula (4).

\section{THE STREAKED HAIR-STREAK, Or LIPOROPS BUTTERFLY.}

\section{Thecla liparops, Boisduval and LeConte.}

Butterfly-Dark brown on upper side, grayish below. The lines on the underside are arranged in pairs, and very narrow. The spots at the anal angle are obscure and blackish. Expanse, 1.15 inches, $29 \mathrm{~mm}$.

Early Stages-Almost entirely unknown.

Food-The caterpillar feeds on a variety of plants, oaks, willows, the wild plum and the Ericaceae.

Distribution-It ranges through the northern Atlantic States and Quebec to Colorado and Montana, but it is nowhere common. We have not taken it.

THE BANDED HAIR-STREAKED, Thecla calanus. Hubner.

Butterfly-Expanse, 1.2 inches, $30 \mathrm{~mm}$.

The upper surface of the wings is dark brown or blacsish brown There is sometimes an orange spot at the anal angle. The under side is blackish slate brown, nearly' as dark as the upper surface; there is a dark bar edged with bluish white at the end of the discal cell of both wings, and just outside of the middle a row of small, dark, blue-edged spots, which form an almost continuous line; and a submarginal series of crescents, edged within with white.

Early Stages-The caterpillar is $\mathbf{1 . 5}$ inches in length, slug-shaped, bright grass green or purple brown in color, marked with lighter and darker lines running lengthwise of the body. The food plants are oak, hickory and butternut.

Distribution-East of thə Rocky Mountains.

THE ACADIAN HAIR-STREAK, Thecla acadica, Edwards. Plate I.

Butterfly-Expanse, 1.5 inches, $38 \mathrm{~mm}$. The upper surface of the wings is of a uniform blackish slate brown; costal edge of fore wings, especially near the base, tawny. Anal angle of the hind wings with a submarginal, orange, lunate spot, which is indistinctly continued to the inner border of the wing. The under surface is pearl gray; on each wing at the end of the discal cell there is a dark bar edged with white; beyond this a bent row of roundish black spots encircled with white; and beyond this a submarginal row of black lunules edged within with white, and followed without by orange spots. The orange spots of the front wings are inconspicuous; but on the hind wings they increase in sizze toward the anal angle, except that one is largely covered by a blue patch.

Early Stages-Caterpillar; Length about one-half inch; slug-shaped; the brown head is very small; the body is almost oval in outline and grass green in color. Two yellowish stripes along the side include a row of oblique short stripes of the same color. The food plant is the willow. 
Distribution-From New England west to Montana and Vancouver. South to Los Angeles. Taken in Nevada and Arizona. In Montana taken occasionally at Flathead lake. It is scarce.

\section{Genus INCISALIA, the Elfins.}

Butterfly-The hind wings have only a short projection, if any, at the anal angle. The under side of hind wings without a row of orange spots. Dark brownish butterflies, with the fringe of the hind wings a scalloped outline. No prominent tail like prolongations of the wings. In the outer third of the inner margin of the hind wings there is a deep rounded excision, producing a conspicuous lobe at the anal angle. Discal spot present in the fore wings of the males, usually inconspicuous. Under surface almost as dark as the upper, especially on the basal half, which is separated from the outer half by a wavy line.

\section{Key to Species.}

A large rusty brown space in the middle of each wing of the female, but near the anal angle of the male niphon

The inner of the two dark bands on the outer third of the wing not sharply angulated below the third median nervule eryphon

Outer half of the lower surface of the hind wings uniform rust red augustus

Outer half of lower surface of hind wings sprinkled with pale lilac

irus

THE HOARY ELFIN, Incisalia irus Godart. Fig. 97.

Butterfly-Expanse, 1.10 inches, $23 \mathrm{~mm}$. Grayish brown on the upper side; wings below are of the same color, paler on ahe outer margins, and darker toward the base; the outer half of the lower surface of the hind wings sprinkled, especially near the margin, with pale lilac scales, giving it a hoary bloom.

Early Stages-The caterpillar is said to feed on the plum.

Distribution-The species is rather rare, but has been found from the Atlantic to the Pacific in latitude of New England. In the state it has been taken on Mount Ascension, near Helena (one), by Brandegee; at Winscott (one), 6,000 feet (near Helena), by Brandegee; at Miles City (one) by Wiley.

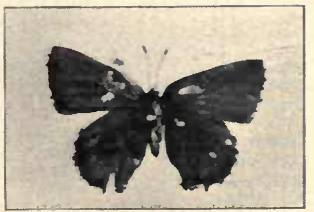

Fig. 97. Incisala irus.

THE BANDED ELFIN, Incisalia niphon Huebner.

Butterfly-Expanse, 1. 10 inches, $28 \mathrm{~mm}$. Upper side dark blackish brown, a large rusty brown space in the middle of each wing of the female, but only near the anal angle of the male; a distinct white or whitish edging near the base of the under side of the hind wings, limit- 
Ing a darker band that occupies the outer two-thirds of the basal half of the wing; males with a small, oval, sub-costal sex mark. The under side is light brown, sprinkled with white scales so as to be hoary. Fore wings with a brown bar at the end of the cell, edged outside with white; a brown spot farther toward the base. Beyond the cell a somewhat zig. zag white line, beyond this a submarginal row of dark brown lunate spots. There are no tails, but three prominent teeth or angles to each hind wing. There are white fringes to both wings.

Early Stages-The larva is green and pubescent, longitudinal stripes on the back, the middle one pale yellow, the other two white. The head is brown. The chrysalis is grayish, with four rows of small spots, of which the two middle are black, the others ferruginous. The food plant is the pine.

Distribution-From the Atlantic westward to the Rocky Mountains. In Montana it has been taken at Miles City by Wiley, and at Bozeman by Cooley. So far as we know at present it has not been taken west of Bozeman.

THE ERYPHON HAIR-STREAK, Incisalia eryphon Boisduval. Fig. 94.

Butterfly-Closely resembles niphon, both on the upper and under side of the wings, but easily distinguished by the fact that on the under side of the fore wings the inner of the two dark bands on the outer third of the wing is not sharply angulatel below the third median nervule, and is in general parallel with the sub-marginal line.

Early Stages-These have not been described.

Distribution-A Pacific coast species that has travelled across the mountains eastward as far as Miles City, Montana, where it has been collected by Wiley. Cooley has collected it at Bozeman and Brandegee at Mount Ascension near Helena, east of the range. We have collected it Missoula and at Lo Lo Hot Springs.

\section{THE BROWN ELFIN or AUGUSTUS BUTTERFLY, Incisalia augustus Kirby.}

Butterfly-Expanse, .90 inch, $23 \mathrm{~mm}$. Brown on the upper side, paler on the under side. The fore wings are marked below by a straight incomplete median band, and the hind winks by an irregular curved median band or line. back of these lines toward the base both wings are darker brown. The outer half of the lower surface of the hind wings a pretty uniform rust red, darkest near the margin.

Early Stages-The caterpillar is "carmine red," covered with very short hair, each segment involute above, with double foveae. The chrysalis is pitchy brown, covered with very short bristly hair, the wing cases paler. Holland says the food plant is unknown. Fiske thiuks from actions the food plant is the blueberry.

Distribution-The species is found in New England and northward and westward into the British Possessions. It is a boreal species. Elrod has taken it at Missoula, Cooley at Bozeman at 5.400 feet, May 31. 1900.

\section{Genus CALLOPHRYS, Billberg. \\ THE GREEN WHITE-SPOTTER HAIR-STREAK, Callophrys dumetorum Boisduval.}

Butterfly-Expanse, 1.10 inches, $27 \mathrm{~mm}$. Dark fawn-color above, sometimes tinged externally with reddish. On the under side both wings 
are green, the primaries having a short straight band of white spots on the outer third, and the secondaries a small white spot on the costa beyond the middle, and two or three conspicuous white spots near the anal angle.

Early Stages-We know practically nothing of these.

Distribution-The Rocky Mountains and California.

\section{Genus ERORA Scudder.}

\section{THE EARLY HAIR-STREAK, Erora laeta. Edwards.}

Butterfly-Expanse, .75 inch. The wings are brown, glossed with bright blue above; on the under side pale fawn. with a band of pale red spots on both wings about the middle, and a few similar spots on the outer and inner margins of the hind wings.

Early Stages-Unknown, save that the egg has been described by Scudder.

Distribution-Dyar gives it as Montana and Colorado. Holland says it has been taken in Arizona. It is rare in collections. We have not taken it.

\section{Genus STRYMON.6Hubner.}

THE CORAL HAIR-STREAK, Strymon titus Fabricius.

Butterfly-Expanse, 1.30 inches. $32 \mathrm{~mm}$. Upper surface dark brown, with or without an outer marginal row of orange spots or an indistinct or ange band; males with discal stigma. Under surface soft slaty brown, sometimes tinged with violaceous; outer half of wings crossed by a series of black spots, encircled or bordered without with white; between these spots and outer margin is a series of small black lunules, bordered within with white and followed without oy a corresponding series of coral red or orange spots, indistinct or wanting on the fore wings, prominent on the hind wings.

Early Stages-The caterpillar when full grown is sevent-enths of an inch long, elliptical in shape, heavy, very small, bilobed, and shining, with a streak of dull white across the front above the mandibles. Body above dull green, with a yellowish tint especially on the anterior joints, and thlckly covered with very short brown hairs. A dark green dorsal line from joint two to four; a patch of dull pink on anterior joints. On the posterior joints is a much larger rosy patch, extending from the posterior of joint nine to the end of the body. Posterior part of the body suddenly flattened, side acutely sloped. The chrysalis is .45 inch long, glossy pale brown, with many small dark brown dots, and thickly covered with very short brown hairs, too fine to be seen without a lens. The larva feeds on the wild cherry and plum.

Distribution-It occurs from the Atlantic to the Pacific, from Maine to Georgia. At the present time a single specimen has been taken iln the state, at Missoula. It is therefore quite rare. Coubeaux has a specimen collected at Big Sandy. Coues collected a single specimen in 1874 among the mountains of our northern border, called by Edwards Thecla mopsus. 
Genus GAEIDES, Scudder.

EDITH'S COPPER, Goeides editha Mead. Fig. 98.

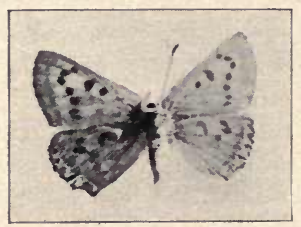

Fig. 98. Gaides editha.

Butterfly-Expanse, 1.25 to 1.35 inches (31 to $34 \mathrm{~mm}$.) Male fuscous above, narrowly edged with black along the outer margin, and with black discal bar; the usual spots show through very faintly on the upper side. Hind wings fuscous, with similar black edge, and within this a row of four or five black spots near the anal angle. The two nearest this angle are surrounded by an irregular ochraceous line. Under side of fore wings gray Inclining to fuscous, cinereous on the disc, with the black spots as allied species. Hind wings below gray-fuscous clouded with white. A rather broad band of gray-fuscous occupies the outer margin; this band is crenated inwardly and cut by a fulvous line which begins on the abdominal margin, extends out on the submedian and last branch of median nervules, thus leaving a white, black pupiled half.ocellus at anal angle, a large gray-fuscous crescent in the next interspace, and next to this a white, black-pupiled ocellus; in this respect the present species resembles Xanthoides and differs from Dione, which has much more fulvous. At the inner edge of the gray-fuscous band the white clouding is condensed into a continuous line of broad lunules, and at the inner border of this is the row of spots always fouund in this genus; these spots are quite large, pale gray-fuscous, edged with black and surrounded by white; the discal bar is usually confluent with the dot within the cell, so as to form an irregular horse-shoe mark.

Fringes of all the wings composed of scales of two lengths, the upper and shorter set being nearly black, the lower ones white; sometimes the black scales are a little longer in certain places, thus making the fringe seem white cut with black.

The last branch of median nervule of hind wings prolonged into a very slight tooth; this is more distinct in the female, being there about as in Xanthoides, male.

The female differs from the male in always having at least a small fulvous or ochraceous cloud upon the disc of fore wing, and a similarly colored streak at the outer angle. The cloud upon the disc is sometimes so extended as to cover half the surface of the wing. The spots of lower surface are rather distinctly shown above. In the middle of secondaries there is often an iroration of fulvous scales and a distinct scalloped fulvous line along the outer màrgin, enclosing a black crescent, or double dot near anal angle and smaller dots above. 
Under side like the male, but brighter, and with markings more distinct; a fulvous tint is also seen at outer angle of primaries.

This pretty little species may be distinguished from Xanthoides, its nearest ally, by its smaller size, the much more convex outer margins and more rounded outer angle of primaries, the blunter tooth of secondaries, the white clouding below and the large size of all the spots. (The above is a copy of the original description.)

Early Stages-Unknown.

Distribution-The species is recorded from Montana and Nevada. In the state it has been taken at Bozeman (2) by Cooley, and in the Swan Range, at 7,000 feet, near the Biological Station.

\section{THE GREAT COPPER, Gaides xanthoides, Boisduval.}

Butterfly-Expanse, 1.50 to 1.60 inches.

The species is easily recognized by its size, which is the largest of the group in North America, and by its creamy-white under surface, spotted with distinct small black scots, in large part reproducing the spots of the upper side.

Distribution-The species is reported from California and Montana. In the state $t$ has been taken by Brandegee at Helena (1), and by Wiley at Miles City (2).

Genus EPIDEMIA Scudder. Fig. 99.
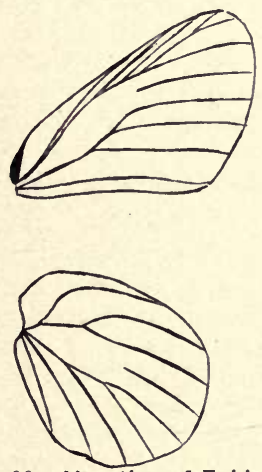

Fig. 99. Venation of Epidemia.

THE PURPLISH COPPER, Epidemia hellioides Boisduval. Fig. 100.

Butterfly-The male has the fore wings broadly shot with irridescent purple. The female has the fore wings of fulvous, with a broad black border. On the under side, the fore wings are pale fulvous, the hind wings a tan color, with a marginal row of brick red crescents. The usual black spots are found on both wings. Expanse, 1.15 to 1.30 inches, 29 to $32 \mathrm{~mm}$.

Early Stages-These are practically unknown.

Distribution-The University of Montana collection has over a hundred specimens taken at Missoula, Flathead Indian Reservation, and Uni- 
versity of Montana Biological Station by Elrod, by Douglas at Fish Creek in Sweet Grass County. It was abundant at the Biological Station at Bigfork in 1903, and in August, 1904. Cooley has many specimens from Bozeman, and Wiley collected many at Miles Ciiy. Brandegee has it in his collection from Helena. It has been taken by Coubeaux in the Little Belt and Bear Paw Mountains.

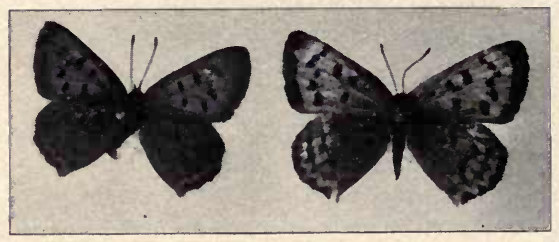

Fig. 100. Epidemia helloides, left figure male, right, female.

REAKIRT'S COPPER, Epidemia mariposa Reakirt.

Butterfly-Small, with a broad dusky band on the wind wing of the male, and on the fore wing of the female. The male is purplish red above, the female kright red with the usual spots. On the under side the fore wings are pale red, the hind wings clear ashen grey, with the markings. Expanse, 1.10 inches, $28 \mathrm{~mm}$.

Early Stages-Undescribed.

Distribution-The species ranges from British Columbia into northern California, Montana and Colorado. We have taken it in the Yellowstone National Park.

\section{Genus HEODES, Dalman. The Coppers.}

THE AMERICAN COPPER, Heodes hypophleas Boisduval.

Butterfly-Expanse, 1 inch, $25 \mathrm{~mm}$. Upper surface of fore wings shining fulvous with a blackish brown border, narrow on the costa and hind margin. Beyond the cell is a row of prominent black spots. Hind wings blackish brown, and a terminal fulvous band, not reaching the apex, containing four black spots on the edge; at the end of the cell a black bar. Under side of fore wings fulvous, paler than above; the apex and whole of hind wings grey.

Early Stages-Eggs ncarly round, a little flattended at the apex. They are pale green overlaid with a white notwork. The larva is elliptical, dull rosy-red, with a yellowish tint on the under side. The body is downy. The chrysalis is attached by the end of the abdomen.

Distribution-Found in northern, midde, and western states. Not rare at Miles City (Wiley). We have not taken it.

\section{Genus CHALCERIA Scudder. Key to Species.}

Under side of fore wings same color as upper, spots repeated snowi Under side shining white rubidus 
SNOW'S COPPER, chalceria snowi, Edwarc's. Fig. 101.

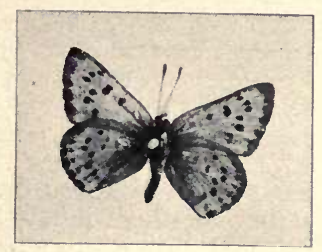

Fig. 101. Chalceria snowi.

Butterfly-Expanse, 1.15 to 1.25 inches, 28 to $31 \mathrm{~mm}$. A mediumsized species, easily recognized by the even, rather black border on both wings on the upper side, and the dirty-gray co or of the hind wings on the under side. The color above is red, brighter than rubidus, black border to both wings, dark at base. A row of black szots across each wing about one-third the distance from the apex to the baze. Two black spots in the discal cell of the front wing, a larger spot at the outer end of the cell.

Under side of fore wing same color as upper, tue spots repeated. Antennae black, tipped with reddish fulvous; palpi, legs and body clothed with white hair.

Early Stages-Unknown.

Distribution-It is found in Co'orado at high e evatous, and is reported from Alberta and British Columbia. Only one specimen in the collections examined, taken by Cooley in Gallatin county, July 12, 1902, at 9,400 feet.

Remarks-The species is named in honor of Chancellor Snow, of the Universitly of Kansas and occurs at high elevations. It is a beautifuI and delicate little creature, worthy of the effort necessary to capture it.

THE RUDDY COPPER, Chalceria rubidus, Behr. Plate I.

Butterfly-Rather large species; the ma'e on the upperside is pale lustrous red, with a narrow black marginal band and uziformly conspicuous white fringes. The upperside of the female is a little l'ghter in the ground color; on the underside the wings are shising white, the secondaries immaculate. Expanse, 1.30-1.50 inches.

Early Stages-Unknown.

Distribution-The species is found in Oregon, Nevada and Montana. Wiley records it as rare at Miles City. Brandegee has one specimen from Gold Creek and Cooley one from Bozeman. Coubeaux has one specimen taken at Livingston. Dr. Elliott Coues took a single specimen near Three Buttes, August 8, 1874. Edwards says Dr. Hayden sent him occasional specimens from Montana. It seems to be everywhere rare.

\section{Genus CUPIDO, Schrank.}

THE LYCAEA BLUE, Cupido lycaea, Edwards, Plate XI, 1 and 2.

Butterfly-Expanse, 1.25 to $1.40 \mathrm{in}$., 31 to $35 \mathrm{~mm}$. The adult male is pale blue above, the margins pale dusky. The black marks do not show through. The female is dusky, the wings shot with blue at their bases. 
On the underside the wings are whitish. There is a row of black spots on the fore wings and a par at the ends of the cell. The hind wing has also a row, but not so large.

Early Stages-These await description.

Distribution-The butterfly is found in the region of the Rocky Mountains, from New Mexico to Montana. The University of Montana collection has many specimens, collected as follows: at Madison Lakes by Douglas, at New Chicago by Fred D. Smith and Douglas, at Missoula by EIrod, and at Sinyaleamin Lake in the Mission Mountains by Elrod. At Sinyaleamin lake large flocks assembled about camp on the lake bank. Cooley has two from Bozeman, one from 5,800 feet altitude. Coubeaux reports it rather common in the mountains near Big Sandy.

THE GREENISH BLUE, Cupido saepiolus, Boisduval. Plate XI.

Butterfly-The male on the upperside bas the wings blue, shot in certain lights with brilliant green. Ine female on the same side is dusky, with greenish blue scales at the bases of the wings and often with reddish markings on the outer margin of the hinds wings. On the underside, the wings are gray or pale wood-brown with greenish blue at their base and a profusion of small spots margined with white. Expanse, .951.10 in.

Early Stages-These have not been studied.

Distribution-The species ranges from British Columbia to Colorado.

$\$ \mathrm{n}$ western Montana this is a very common species. On the mountain slopes by the University it abounds in early spring, collecting in considerable numbers by the damp places. Along the roadside in the mountain canyons it is a conspicuous figure. It is found throughout the Mission Mountains and around the Biological Station at Flathead lake.

\section{Genus NOMIADES Hubner.}

THE SILVERY BLUE, Nominades lygdamas Doubleday.

Butterfly-Expanse, .85 to 1.10 inches, 21 to $27 \mathrm{~mm}$. Upper side of wings of male pale silvery blue, narrowly edged with black; the wings of the female above darker blue, dusky on the borders, with a dark spot at the end of the cell of the primaries. Under side of wings pale chocolate brown, with a submarignal band of black spots, margined with white, on both wings, as well as a spot at the end of the cells, and one or two on the costa of the secondaries.

Early Stages-These are unknown.

Distribution-Found in the South Atlantic states, Colorado, California, New Mexico, and in the Kootenai district of British Columbia. In the state collected by Brandegee at Helena, one male, and by Cooley at Bozeman, two males.

\section{Genus AGRIADES Hubner.}

THE RUSTIC BLUE, Agriades rustica, Edwards. Fig. 102B.

Butterfly-Expanse, .90 to 1.00 inches, 23 to $25 \mathrm{~mm}$. Male bright blue above, female darker. Under side pale-gray on the secondaries, with white spots; primaries with a row of black spots, and a discal black spot bordered with white.

Early Stages-Unknown. 


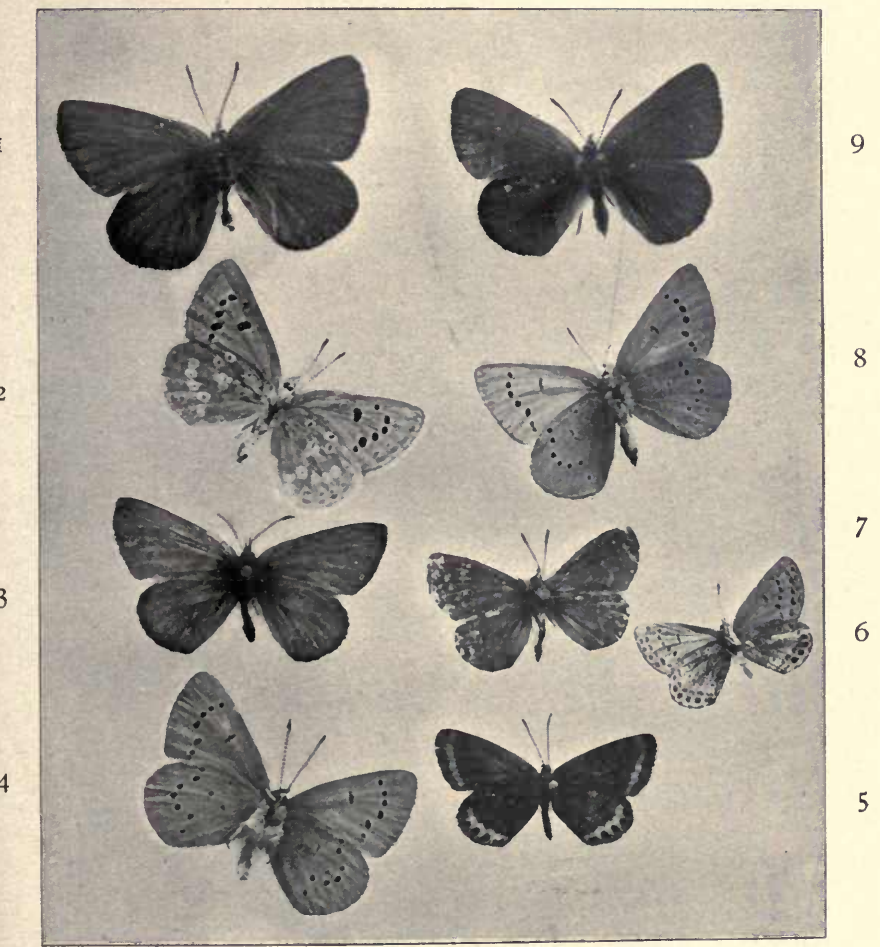

1, Cupido lycaea, male; 2 , under side of same; 3 , Cupido saepiolus male; 4 , under side of same; 9 , female of same; 8 , under side of female of same; 7, Rusticus melissa, male, upper side; 6, under side of same; 5 , upper side of female. 

Distribution-Found in Colorado, Montana and British America. In the state taken at Bozeman by Cooley, one specimen, and at Bear Paw Mountains by Coubeaux.

\section{Genus RUSTICUS Hubner. \\ Key to Species.}

Orange red or pinkish band on the hind wings

Dark crescents of the under side showing as spots on the upper side

Male with narrow black marginal line and white fringes

Male with wings colored dirty gray below, with black spots

glaucon

melissa

shasta

THE ACMON BLUE, Rusticus acmon Doubleday and Hewiston.

Butterfly-Male blue; female brown. It may be distinguished by the broad orange-red or pinkish band on the hind wings, marked by small black spots. On the underside it is marked much like L. melissa. Expanse, $.90-1.10$ in.

Early Stages-Unknown.

Distribution-It is found from Arizona to Washington and Montana.

The University of Montana collection contains two specimens from the Yellowstone National Park. Brandegee has it in his collection from Helena.

THE COLORADO BLUE, Rusticus glaucon, Edwards.

Butterfly-Purplish blue, having the dark crscents of the underside showing as spots on the upper side. The female has a band of orange spots on the margins of the secondaries. Expanse $1.00 \mathrm{inch}, 25 \mathrm{~mm}$.

Early Stages-Unknown.

Distribution-It ranges from Washington to California and eastward to Colorado, where it is juite common in the mountain valleys. The University of Montana collection contains 3 specimens; 1 from Missoula, and 2 from Geyser Basin.

THE ORANGE-MARGINAL BLUE, Rusticus melissa, Edwards. Plate XI, 5, 6 and 7, and Fig 102.

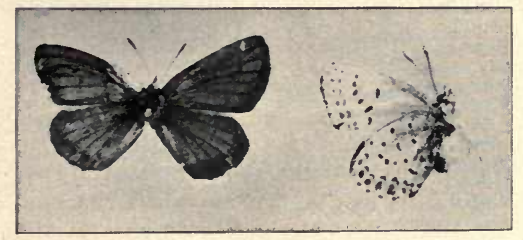

Fig. 102. Rusticus melissa, male, upper and lower surfaces.

Butterfly-The male on the upperside is pale blue, with a narrow black marginal line and white fringes. The female is brown or lilacgray, with a series of orange red crescents on the margins of both wings. 
On the underside the wings are stone-gray, with the usual spots, and on the secondaries the orange colored marginal spots are oblong, tipped inwardly with black and outwardly by a series of metallic green maculations. Expanse, .90-1.15 in.

Early Stáges-Very little known.

Distribution-It is found from Kansas to Arizona, and northward to Montana. The University of Montana collection contains specimens from the Mission Mountains, Flathead Indian Reservation, Missoula, New Chicago (Smith). It is reported as common at Miles City (Wiley). It is abundant around the University of Montana Biological Station at Flathead Lake. Taken by Couzeaux in the Bear Pow Mountains. Allen has it from Dillon. Coues collected a number of specimens from a number of localities along our northern border in 1874 .

THE SHASTA BLUE, Rústicus shasta, Edwards.

Butterfly-The male is blue; the female brown. On the underside the wings are a dirty gray, with black spots, and in addition, on the hind wings, there are a number of small marginal spots, surmounted by metllic colored bluish green scales. Expanse, 1.00 inch.

Early Stages-These have not been described.

Distribution-It is found in Montana and Nevada. It is also reported from northern California and Oregon.

There are two specimens from Martinsdale in the University of Montana collection.

\section{Genus CYANIRIS Dahiman.}

THE COMMON BLUE or SPRING AZURE, Cyaniris ladon, Cramer.

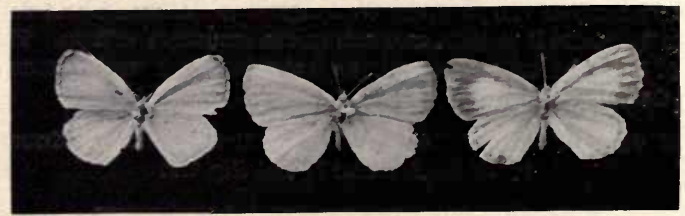

Fig. 102A. Cyaniris Iadon, slightly reduced.

Butterfly-Expanse of wings, 9 inch to 1.4 inches, $23-25 \mathrm{~mm}$. The species is subject to great variation. In general terms, the upper side of the wings of the male is a deep azure-blue with a delicate terminal black line. Fringes black on the apical part of the wings, but white barred with black on the rest of the fore wings and on the hind wings.

The fore wings of the female have a broad blackish outer border, in some examples extending along the costa. The hind wings have a blackish costa, and a row of dark spots along the outer margin. The ground color is usually a lighter blue on the females than on the males.

The under side is a very pale silvery gray, with a silky lustre, and there are the following pale brown markings: a row of spots along the outer margin, each preceded by a crescent; a curved row of alongate spots across the disk of the fore wings; and several small spots on the basal part of the hind wings. 
The butterfly exhibits a very complicated polymorphism, both seasonal and sexual; nine forms are now recognized by entomologists. The form occurring in Montana is C.-ladon ladon.

Early Stages-Length, two-fifths of an inch, slug shaped, dark brown head. Body white with a dusky line down the back and a greenish tinge along the sides.

Food-The larvae feed on dogwood, actinomeris, black snake-root, sumac, spiraea and many other plants.

Distribution-Its distribution is very wide, extending from Alaska south to Arizona, east to the Gulf of Mexico, and north to the St. Lawrence. Coubeaux reports it abundant around Big Sandy.

\section{THE WESTERN TAILED BLUE, Everes amyntula Boisduval.}

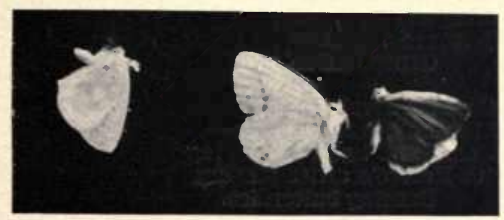

Fig. 102B. Everes amyntula, the two right hand figures, and Agriades rustica, left hand figure.

Butterfly - "Closely resembling L. comyntas, of which," says Holland, "It may be only a silghtly modified western form. Until the test of breeding has been applied we cannot be sure of this."

Description of comyntas-Expanse of wings from .7 to 1 inch, 18 to 25 $\mathrm{mm}$. Hind wings with one thread-like tail. The males are dark violet-blue above, with a narrow blackish outer border. Along the outer margin of the hind wings are several black spots, and usually one or two orange crescents. The female are blackish brown, some specimens with bluish at the base. The black spots of the hind wings are often obscure.

Underside whitisn gray; both wings with a double row of spots along the outer margin, the inner row crescents; between this and the cells a fow of black spots circled with white, the row on the hind wings broken twice. Tuere is also a bar at the end of each cell, and on the hind wings a spot in the cell, and one above. Near the anal angle are two or three orange crescents, enclosing each a black spot with a circle of silver scales.

Amyntula differs from the above as follows: The males are lighter blue above, the dark border much reduced. The black spots prevail, reduced, but the orange crescent has reduced to a black spot. The females are brownish black with a trace of coppery brown, the primaries with a large wash of blue over the posterior portion. The black spots are larger than in the male.

Early Stages-Unknown.

Distribution-It ranges from the eastern foothiıls of the Rocky Mountains to the Pacific in British America and the northern tier of western states. There are seven specimens in the University of Montaan collection from Sinyaleamin lake in the Mission Mountains. Coubeaux collected it in tne Bear Paw Mountains. 


\section{Butterlly Fancies.}

Bits of fancy on the wing In tue sunbeam hovering, Nimbly on the breezy air, Can you be withount a care, Thronging butterflies"

Once a caterpillar shroud,

Now in brightest winged crowd,

Life's intangible mysteries, Unimprisoned fantasies, Gauzy butterflies.

Better than the rival woods, All of Nature's varied moods,Tints oi dark anc light, portraying As with Nature's artist playing, Dancing butterflies.

Whitness caught from mountain-crown, Softest greys and sombre brown, Brushed with dust of finest sift, Streaked-witn blue, a storm-cloud rift, Gleaming butterflies.

Vieing with the veering Wind In thy wooing unconfined, Near all flowers thy list'ning ear, Trembling like a fluttering fear, Vagrant butterflies.

Fanning blushes of the roses, Ever changing are thy poses, Couriers fleet of fairy news

Whisp'ring of the coming dews, Cunning butterfiles.

Skimming perfumed meadow lots, Ye are Nature's sweetest tho'ts, Fit to flit with soul of child, Fairies fed with honey wild, Golden Butterflies.

Hither, thither, in delight, Circling round in rythmic flight,

If we had but keener ear, Could we more of music hear, Lyric butterflies?

Golden links in summer's chain, Tell me all my heart would fain; Give to me thy revelations, Incarnate imaginations, Fleeting butterflies. 
Sleeping in a rose's breast,

By her paling petals prest,

Fainting as her heart throb's cease,

While the wails of winds increase,

Dying butterflies.

University of Montana, June 1, 1905. 


\section{THE SKIPPERS, SUPERFAMILY HESPERIINA.}

Some authors consider the skippers to constitute a superfamily distinct from the butterflies. They are called skippers on account of their peculiar mode of flight. They are day-fliers, like butterflies, darting suddenly from place to place. When at rest most species hold the wings erect in a vertical position like butterflies; in some the fore wings are so held, the hind wings being extended horizontally. The antennae are thread-like, and enlarged toward the tip; but in most cases the extreme tip is pointed and recurved, forming a hook. The abdomen is usually stout, resembling that of a moth rather than that of a butterfly. Skippers are most easily distinguished by the peculiar venation of the fore wings, see Fig. 102, the radius being five-branched, and all the branches arising from the discal cell (R.-M. of Comstock).

There are two families of skippers, the Megathymidae or GIANT SKIPPERS, and the Hesperiidae or Common Skippers. The former is not reported from the state, and hence not included in this list.

THE COMMON SKIPPERS. Family Hesperiidae. Fig. 102.

The figures following represent the family. The larvae have large heads and strongly constricted necks. They usually live concealed in a folded leaf or in a nest made of several leaves fastened together. The pupae are rounded, not angular, resembling those of moths more than those of butterflies. The pupa state is passed in a slight cocoon, which is generally composed of leaves fastened together with silk and thinly lined with the same substance.

Fig. 102. Venation of Hesperiidae.
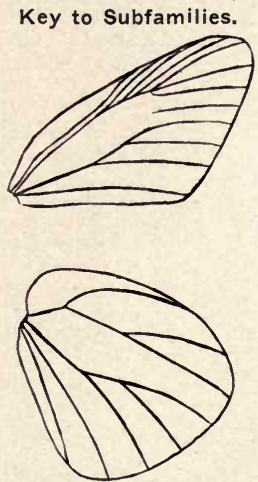

Antennae usually ending with a finely pointed terminal crook, occasionally without crook and ending bluntly; males usually with a brand on the fore wings, never with a costal fold. Skippers with a brand and their allies 
Antennae usually with a long club which is bent at a considerable distance from the tip; males almost invariably with a costal fold, never with a brand. Skippers with a costal fold and their allies

Hesperiinae, P. 143

\section{Subfamily Hesperiinae.}

In this subfamily are included the larger of the common skippers, as well as some that are of smaller size. Most of the species are dark brown, marked with white or translucent, angular spots. The antennae usually have a long club, which is bent at a considerable distance from the tip. The venation is shown in Fig. 102. The most distinctive feature is exhibited by the males alone, but is lacking in some species. This consists in a fold in the fore wing near the costal margin, which forms a a long, slit-like pocket, containing a sort of silky down. This is a scent organ. Tubular scales, the androconia, open into it. This pocket is difficult to see when the pocket is closed.

\section{Key to Genera.}

1. Fore wings with a broad, bright yellow band near the middle $\quad \stackrel{?}{2}$.

Fore wings not crossed by a broad, bright yellow band

2. With a large silvery-white spot in the center of the lower side of the hind wings

Epargyreus, P. 143

3. Upper surface of wings black or brown, with a few white spots on the fore wings or with none, hind wings not checkered with white 4 .

Both fore and hind wings checkered with many white spots 9.

4. Club of antennae hooked; anal angle of hind wings slightly prolonged

Cocceius, P. 144

Club of antennae sickle-shaped; anal angle of hinds wings rounded 8 .

Club of antennae thickened at the end, which is obtuse and bare 5 .

5. No costal fold in the male

Hesperopsis, $\mathbf{P}$.

A costal fold in the male

6.

6. A pair of long lobes covering a bare hollow at base of addomen of male Scelothrix, P.

These lobes short or absent

7 .

7. Hind tibiae with a hair pencil

Heliopetes

Hind tibiae without a hair pencil

Pyrgus, P.

8 Fore wings entire, with a costal fold in the male; costal fold short, less than half the margin

Pholisora, P.

Costal fold of the male long; over half the margin

10.

9. The white spots in the band just beyond the middle of the fore wings much broader than high

Pyrgus, $P$.

The white spots in the band just beyond the middle of the fore wings but little if any broader than high

Scelothrix, P.

10. Third joint of palpi moderate, less than twice as long as wide

Thanaos

\section{Genus EPARGYREUS.}

\section{Key to Species.}

1. Hind wings more or less produced or tailed at the anal angle Hind wings produced not tailed

2. Under side of hind wings with a silver band in the middle 
THE SILVER-SPOTTED SKIPPER, Epargyreus tityrus, Fabricius.

Fig. 103.

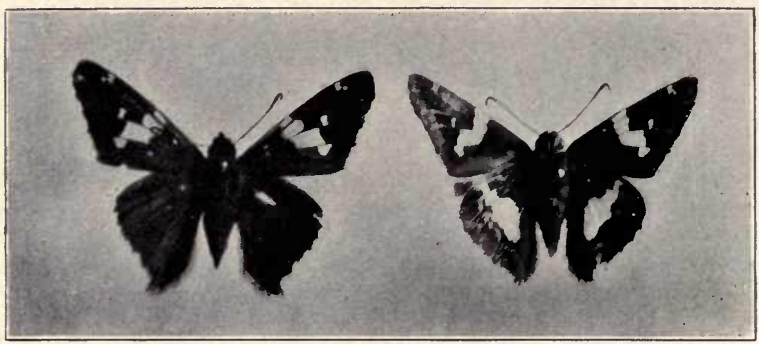

Fig. 103. Epargyreus tityrus, upper (left) and lower (right) surfaces.

Butterfly-Expanse, 1.75 to 2.00 inches, 43 to $50 \mathrm{~mm}$. Upper surface dark brown. The fore wings are crossed by an oblique yellow band of four large, spots, from the middle of the costa to near the posterior angle, where it ends in a rounded spot. Beyond there is a narrow spot in the first median interspace extending from vein to vein. Fringes gray and brown at the edge of veins. Underside aboue the same, but this hind wings have a conspicuous silvery white band in the middle, nearly reaching the cosa; palpi brown, slightly yellowish beneath.

Early Stages-The egg is nearly globular, flattened at the base, with fifteen ridges from the base to apex. Color white, with a bright red spot at apex. The young larva is orange; head short, a few scattered over the body. It feeds upon the common locust, rose, acacia, wistaria, and a species of wild bean.

Distribution-It is found quite generally over the entire United States, more abundantly eastward. In Montana it has been taken by Wiley at Miles City, by Brandegee near Helena, and by Elrod at Flat. head lake.

Genus COCCEIUS.

THE NORTHERN DUSKY-WING, Cocceius pylades, Scudder.

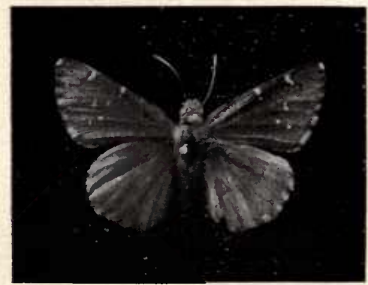

Fig. 103A. Cocceius pylades, slightly reduced. 
Butterfly-Expanse, 1:60 inches, $40 \mathrm{~mm}$. Brown above, darker at base of wings and anal angle; the white spots on the fore wings are mere points, the number and size varying. On the under side the wings are dark brown, shading into hoary-gray on the outer margins. The hind wings are crossed by an irregular basal, median, and post-median brown bands of darker spots, shaded with deeper brown internally. The translucent spots of the upper side reappear on the lower side of the fore wings.

Early Stages-The larva feeds on clover and other plants.

Distribution-The insect is found throughout the United States and Canada, but is not yet reported from the central masses of the Rocky Mountain region (Holland). Dyar gives it in his list. We have not taken it in the state. Wiley's collection contains one specimen from Miles City, June, 1893; Coubeaux has two specimens from near Big Sandy, 1904.

\section{GenUS SCELOTHRIX.}

THE GRIZZLED SKIPPER, Scelothrix centaurea, Rambur. Fig. 104.

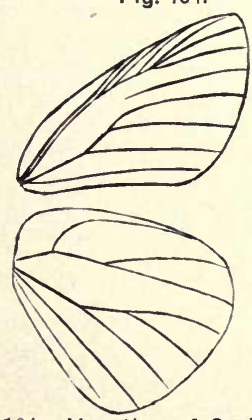

Fig. 104. Venation of Scelothrix.

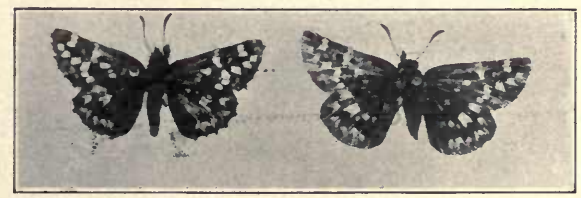

Fig. 105. Scelothrix Centaurea.

Butterfly-Expanse, about 1.25 inches, $31 \mathrm{~mm}$. Upper surface black, tinged with brown, sprinkled somewhat with white scales over the basal half. There is a bar of white in the end of the cell of the fore wings, a less distinct spot of the same below the middle of the cell, and a subterminal row of white spots. There are first three spots in the sub-costal 
interspaces three-fourths of the distance from the base to the apex; two spots beyond the cell, the upper half way from the third spot to the margin; spot five inline with the first three; and an oblique row of four more,-two in the median interspaces and the other two in the mediosubmedian interspace, one next to each vein. Besides this, the cross vein at the end of the cell has some white scales. In addition to these, there are five white spots on the costal edge.

The hind wings have two obscure rows of white spots, the first crossing the end of the cell, the spot on the cell being the most distinct; the second sub-terminal, consisting of a series of inter-venular, somewhat sagittate spots. Fringes white, cut with black at the ends of the veins.

Under side a little paler than the upper, sprinkled over with white scales so as to be grayish brown. The spots of the fore wings are repeated, but enlarged and coalescing. The hind wings have three distinct bands of white, one near the base which does not show on the upper side, consisting of three patches united; the middle one enlarged and blended; the sub-terminal one not much more prominent than on the upper surface.

Body black above, with gray hairs, the scales and hairs below white; antennae annulate with black and white; top of club ferruginous.

Distribution-From the Atlantic coast in New York, West Virginia and North Carolina westward to Colorado, north to Montana. In Montana it has been taken by Elrod at Sinyaleamin lake in the Mission mountains (two); Brandegee has one in his collection from Presto Pass, near Helena; Cooley has one from Shields river at elevation of 9,000 feet. These two last are small and quite dark, but have the characteristic markings of the species.

\section{THE SMALL CHECKERED SKIPPER, Scelothrix scriptura, Boisduval.} Fig. 106.

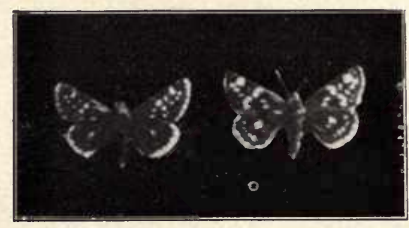

Fig. 106. Scelothrix scriptura.

Butterfly-Small, expanse $.85 \mathrm{inch}, 21 \mathrm{~mm}$. The hind wings on the upper side are about entirely dark gray, the only white being a spot or two at the end of the cell. The fore wings above marked somewhat as iu centaurea. On the under side the fore wings are blackish toward the base, with the costa, the apex, and the outer margin narrowly whitish. The hind wings below are pale, with an incomplete median band of white spots and broad white fringes, which are not checkered with darker color as in the preceding species.

Early Stages-These are unknown. 
Distribution-We have not seen it in the state, nor is it in any of the collections we have examined. It is reported from California, Arizona and Montana.

Genus HELIOPETES Billberg, Helopetes syrichtus, Fabricius.

This species is reported by Edwards among the specimens collected by Carrington and Logan in 1871.

Genus PYRGUS.

THE CHECKERED SKIPPER, Pyrgus montivaga Reakirt, or Hesperia tessellata, Scudder. Fig. 106a.

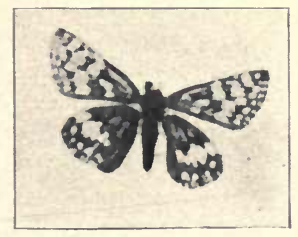

Fig. 106A. Pyrgus montivaga.

Butterfly-Expanse, about 1.20 inches, $30 \mathrm{~mm}$. Male: Upper surface black, the basal third and hind margin of fore wings overlaid with white hairs, as also the inner, part of the hind wings. The outer twothirds of fore wings contain about thirty white spots arranged somewhat in four irregular transverse rows; and five more on the costal edge. The hinds wings have about eighteen spots, arranged in three rows, the spots of the inner row the largest, the middle ones crescent, the outer ones points. Fringes white, with black at the ends of the veins.

Under side of fore wings yellowish white along the costa and the outer margin, the spots of the upper surface repeated, but more or less blended, the space between the spots brownish black. Hind wings white, faintly yellowish; a spot near the base, two irregular transverse bands, and a marginal row of lunules are brownish, these corresponding to the spaces between the rows of white above.

Female-Darker, owing to the spots being smaller, the marginal row of points sub-obsolete. Under side also darker.

Distribution-From Pennsylvania to the Gulf of Mexico, from the Atlantic to the Pacific. In the state it has been taken by Barnes at Aldridge (one); by Elrod at Flathead lake (one) and at Swan lake (one); Wiley has many specimens in his collection from Miles City; Coubeaux has collected it in the Bear Paw Mountains. Collected by Coues along the northern border in 1874 .

\section{Genus HESPEROPSIS.}

THE LENA SKIPPER, Hesperopsis lena, Edward.

Butterfly-Expanse, male, 1.1 inches, $28 \mathrm{~mm}$., female 1.15 inches, 30 $\mathrm{mm}$. Upper side dark brown, glossy; primaries have three small white spots, with traces of a fourth, in an oblique bar from costa, at four-fifths the distance from base to apex; a small spot in cell near outer end; and three minute spots in median and submedian interspaces, two being in the latter, these about three-fifths the distance from base to hind margin. secondaries immaculate. Fringes concolored. 
Under side of primaries dark brown, grayish at base and over apical area, more particularly when seen obliquely. Secondaries gray-brown, caused by a uniform sprinkling of whitish scales over the brown surface; without spots except a transverse abbreviated white dash on middle of disk.

Female-Color of the male; the white spots conspicuous, forming a discal row quite across primaries; a large spot in cell, and a small one in submedlan interspace near base. Under side of both wings as in the male, except that the three costal spots of discal row are repeated, and the spot in cell, but all are reduced.

From one male and one female taken in Montana by $\mathrm{Mr}$. Morrison, 1881. In all four examples were taken.

We have not tken it, nor have we seen any specimens we could refer to the species. Dyar says he has not seen any certainly determined specimens.

Genus PHOLISORA, Scudder.

The Sooty-wing, Pholisora catullus (Phol-i-so'ra ca-tul'lus) Fabricius... Plate XII, and Fig. 107.

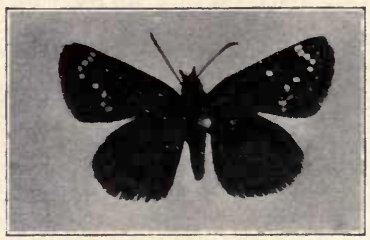

Fig. 107. Pholisora catullus, silghtly enlarged.

Butterfly-Expanse, .80 to 1.15 inches. Brownish black on both sides of the wings, with a faint marginal series and a conspicuous submarginal series of light spots on the primaries. In the male on the upper side, and in addition to these, in the female, a faint marginal series on the secondaries. On the under side only the upper spots of the submarginal series of the primaries reappear. The body and head are black above, the head with three longitudinal white stripes, the ends of the palpi hairs the same color; the palpi and head white beneath, the body blacfl. Fringes concolorous with the wings.

Early Stages-The larva feeds on Monarda, Chenopodium, Ambrosia, and others. It forms a case for itself by folding the leaf along the midrlb and stitching the edge together with a few threads of silk. It lies concealed during the day and feeds at night.

Distribution-It is found over the whole of temperate North America. At Missoula, in the state, it has been taken abundantly. Wiley has in his collection one specimen taken June 7, 1891, another June, 1893, both from Miles City; Coubeaux calls it rather common around Big Sandy.

Brandegee hás one specimen from Mt. Ascension, near Helena, June $29,1902$. 


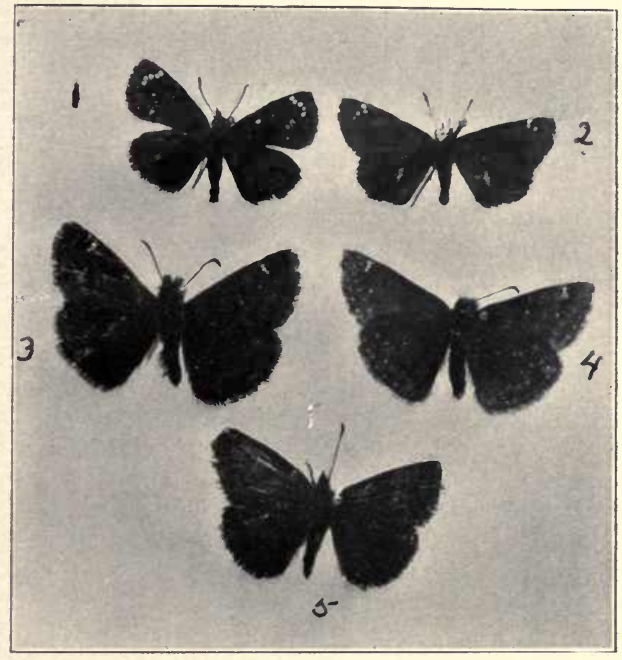

Pholisora catullus, 1, 2, upper and lower sides. Thanaos persius, 3,5 upper side, 4 under side. 



\section{Genus THANAOS, Boisduval.}

Butterfly-Antennae have a moderately large club, curved, bluntly pointed. The palpi are porrect, the third joint almost. concealed in the hair of second. All dark in color.

\section{PERSIUS' DUSKY-WING, Thanaos persius, Scudder.}
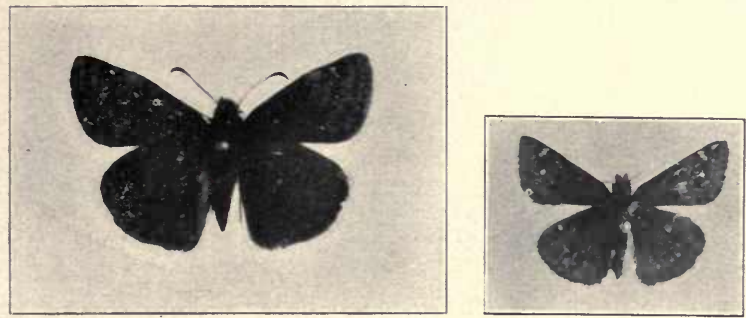

Fig. 108. Thanaos persius, from Helena. Fig. 109. Thanaos persius.

Butterfly-Expanse, 1.2 to 1.4 inches, 30 to $35 \mathrm{~mm}$. Upper surface dark brown with a row of small white spots before the apex of the forewings, and a single one posterior to these. On the fore wings there is a tiansverse pale band just beyond the middle of the wings, but this band is not as well defined as in T. lucilius, which is found in the eastern part of the United States. Hind wings more of a reddish brown than the fore wings, with two rows of indistinct ochraceous spots near the outer margin, and a spot at the end of the cell in typical specimens.

Underside of the females grayish brown, the apical portion of the fore wings gray; the white hyaline spots are repeated, and both wings have two marginal rows of whitish spots. The males are darker than the females.

The species is subject to great variation, some specimens being light and others dark in color. Holland says "There is scarcely any positive clue to the specific identity of the insect except that which is derived from the study of the genital armature of the male, which is a micrscopic research capable of being performed only by an expert in such matters."

Early Stages-The caterpillar feeds on willow and poplar.

Distribution-From New England across to the Pacific, southward as well. In the state it has been taken by Elrod at Missoula and in the Mis sion Mountains; by Douglas and Smith at New Chicago; by Cooley at Bozeman, by Brandegee at Helena, and by Coubeaux at Big Sandy. 


\section{AFRANIUS' DUSKY-WING, Thanaos afranius, Lintner.}

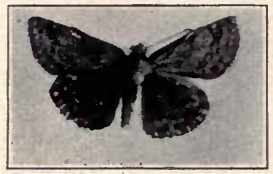

Fig. 110. Thanaos afranius.

Butterfly-The hind wings on the upper side in the male are almost solid black, the fringes paler. On the underside there is a double row of light spots along the margin of the hind wing in both sexes. On the upper side the female is generally lighter in color than the male.

Eariy Stages-Unknown.

Distribution-Common in Arizona. Given in Dyar's list. We have not taken it. One specimen from Bozeman, one from Helena, and one from unknown locality we have referred to this species.

\section{Subfamily PAMPHILINAE.}

In this subfamily is included the greater number of our smaller skippers; however, some of the species are larger in size than many of the Hesperiinae. All of our tawny skippers belong to this subfamily, as well as some black or dark-brown species. The antennae usually have a stout club, with a short recurved tip; sometimes this tip is wanting. Fig. 112 shows plainly the venation. In the majority of our species the males can be recognized by the brand; this is a conspicuous dark patch crossing the disk of the fore wings obliquely. This brand is a complicated organ, composed of tubular scales, the androconia, that are the outlets of scent glands, and of other scales of various shapes; the brand is wanting in some species.

The Pamphilinae are difficult to study, owing to the slight differences in allied species. Either sex, moreover, resembles the same sex of other species much more closely than it does the opposite sex of the same species; and the difficulty is further augmented from the fact that in several species there are iwo distinct forms of females which differ from each other more than either does from the females of certain other species. These species have three forms, one male and two female.

\section{Key to Genera.}

1. Antennae with the point of the club absent; end obtuse

Antennae with the point of the club present; end sharp

2. Fore wings of male with a linear stigma.

Fore wings of male without a linear stigma

3 Under surface of hind wings with silvery whites pots

Under surface of hind wings without silvery white spots

Pamphila

Oarisma

4. Antennae with the point of the club short, less than width of club 5 . Antennae with point of club long, equal to or greater than the middle of club 
5. Antennae in length twice the width of thorax

Antennae short, equal to the width of thorax.

6. Male stigma with modified scales below

Male stigma without modified scales below

7. Stígma apparently continuous

8. A small black area below stigma An obscure, weak fulvous area below stigma

9. Mid tibiae with long distinct spines Mid tibiae not, or very feebly spined

10. Male with a stigma

Genus PAMPHILA, Fabricius.

THE ARCTIC SKIPPER, Pamphila palaeman, Pallas. Fig. 111.

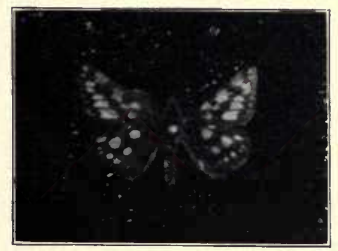

7.

Ochlodes

Thymelicus

Erynnis

10.

Limochroes.

Fig. 111. Pamphila palaemon.

Butterfly-Expanse, 1.10 inches, $27 \mathrm{~mm}$. This butterfly is wholly unlike any other species, and is easily recognized from other skippers of our fauna. The figure shows the markings. The upper side of the wings is dark brown conspicuously marked with yellow spots. The fore wings of the male lack the brand; the spots on the lower side of the hind wings are silvery white.

Early Stages-The caterpillar feeds on grasses.

Distribution-The insect ranges from southern Labrador as far south as the White Mountains and the Adirondacks, thence westward, following a line north of the Great Lakes to Vancouver's Island and Alaska. It ranges southward along the summits of the mountains as far as Southern Californla. Taken in the state by Cooley near Bozeman. One taken at Flathead lake.

Genus OARISMA, Scudder.

THE POWESHEIK SKIPPER, Oarisma powesheik.

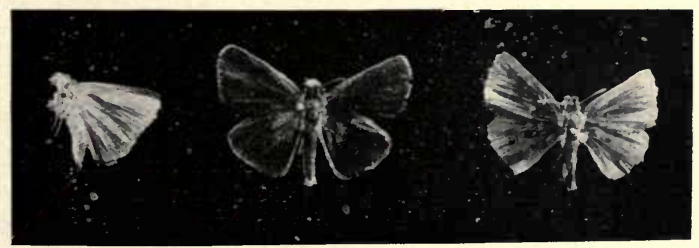

Fig. 111A. Oarisma powesheik. 
Butterfly-Expanse, 1.2 inches, $30 \mathrm{~mm}$. The club of the antennae lacks the terminal hook. The upper surface of both fore and hind wings is dark brown; the costal margin of the fore wings to near the apex is dull yellow; the fore wings of the male lack the brand. On the under side the fore wings are black, edged on the costa and outer margin for a short distance below the apex with light fulvous. The veins and nervules of the hind wings are white, standing forth conspicuously upon the darker ground color.

Early Stages-Unknown.

Distribution-It occurs in Illinois, Iowa, Nebraska, Dakota, and Montana. In the state it has been collected by Coubeaux near Big Sanciy, 1904; by Cooley at Bozeman, July 18, 19v1, and by Wiley at Miles Citv (7), three July 4, 18y2, two June 2, 1893, and two June 17, 1899.

THE GARITA SKIPPER, Oarisma garita, Reakirt, may be experted in Montana. It is light fulvous on the upper side, with the costa of the hind wing somewhat broadly marked with leaden grap; on the under side the fore wings are brighter fulvous, with the inner margin lined with dark gray. The hind wings are paler fulvous, inclining to gray, with the inner margin brignt fulvous. Expanse, .75 to 1.00 inch, 19 to $25 \mathrm{~mm}$.

\section{Genus ERYNNIS, Schrank.}

Butterfly-The antennae are short, less than half the length of the costa; the club is robust, with a terminal crook. There is a discal stigma on the fore wings of the male. The egg is somewhate spherical. The caterpillar feeds upon grasses. The chrysalis is elongated and cylindrical.
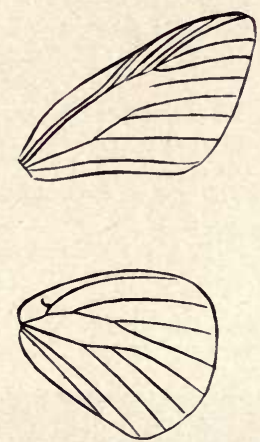

Fig. 112. Venation of Erynnis.

THE UNKAS SKIPPER, erynnis unkas, Edwards. Figs. 113, 114.

Butterfly-Expanse, 1.35 to 1.6 inches, 34 to $40 \mathrm{~mm}$.

Female-Upper surface fuscous, the base and posterior part of the fore wings, and a broad band through the hind wings from the base out, washed with dusky fulvous. The fore wings have a sub-terminal broken row of spots, all whitish but the last, which is yellowish, also a small spot at the end of the cell; the two between the branches of the median 
vein with the outer angles much extended. Hind wings with the subterminal spots of the under side showing through a little.

Under side fuscous gray, sprinkled with pale yellow scales. The spots on the upper surface of the fore wings are repeated, white in color, those of the sub-terminal row blended into three groups, the lower widen-

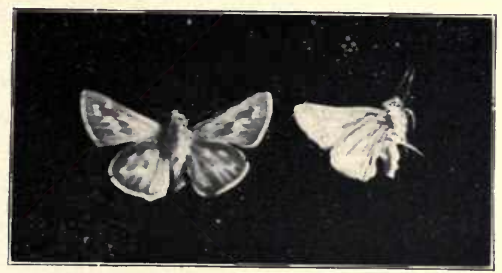

Fig. 113. Erynnis uncas.

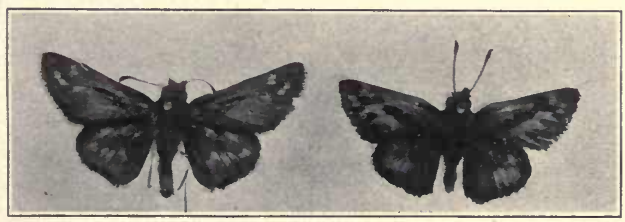

Fig. 114. Erynnis uncas.

ened posteriorly, so as to suffuse most of the posterior angle area. The hind wings have two very much bent white bands, the outer not reaching the inner margin.

Male-Upper surface fulvous, the hinder portion washed with yellow, a row of five yellow spots in the outer fulvous field. Stigma very oblique, narrow, jet-black, contracted in the middle.

Hind wings washed with yellow, inclining to fulvous in the central part; fringes white, fuscous at base. Under side as in the female.

On the under side of this species the wings are beautifully marked, the spots reappearing from the upper as pearly white ones on greenish gray brown.

Early Stages-These are unknown.

Distribution-It ranges from Delaware westward to Colorado and Montana. In the state it has been taken by EIrod at McDonald Lake in the Mission Mountains (1), at Missoula (2), at the Biological Station at Flathead Lake abundantly, and also in the Park at Mid-geyser basin (2). Cooley has collected it at several places in the vicinity of Bozeman. Allen has collected in at Dillon.

THE COMMA SKIPPER, Erynnis comma, Linnaeus.

Butterfly-The following is taken from Scudder's description of Pamphila nevada, which Dyar gives a synonym for colorado, which is the form taken in Montana. 
"The males differ from all the other species of this genus in the clearness of the upper surface of the wings; occasionally the wings are somewhat suffused with dusky, but usually the hind wings have but a narrow edging of blackish, broadened, naturally, along the costal border; and the fore wings, instead of having a distinctly limited bordering, as is common to a greater or less extent in most species, have the wing gradually more and more suffused with a warm bud dusky tint toward the tip, as is not unfrequently the case in P. comma. Sometimes the mesial belt of the under surface is isible above, but occasionally, at least, it is wholly absent. The female scarcely differs, upon the upper surface, from the females of P. comma, except in almost uniformly having the small subapical spots, both those near the costal, and those near the outer border, paler than the others, or nearly white, as occasionally happens in the females of P. comma. Beneath, the mesial white band of the hind wings is more irregular and scattered than in P. comma. In the male it is usually broken up into four patches, connected, by their angles only, into a continuous angular belt; three of these patches, of nearly equal size, but the middle one usually the largest, lie in a straight line parallel to the longer axis of the wing, situated one each in the subcostal and subcosto median interspaces, as far from the outer border as the second patch; the medio-submedian spot further removed from the border than the rest; the ground color of the wing is a greenish griseous, and the spots are narrowly edged exteriorly and interiorly with blackish. The markings of the female are similar, excepting that they are usually a little larger and more obviously continuous,often sending out on the exterior border little shoots of white along the nervules."

This species with its many varieties is found in Europe, America and Asia. In the Canadian Entomologist of 1883 , Vol. XV, is an interesting discussion by Dr. A. Speyer and W. H. Edwards relative to the comparison of specimens from different localities.

There are the following varieties recognized in Dyar's list, Bulletin 52, U. S. Nat. Mus.; oregonia, columbla, colorado, idaho, nevada, assiniboia, laurentina, manitoboldes, juba, viridis, manitoba. In his later revision of the group, Journal N. Y. Entomological Society, September, 1905, he thinks three or four names will suffice. Laurentina Lyman, colorado Scudder equals manitoba Scudder equals nevada Scudder, columbia Scudder, idaho Edwards equals assiniboia Lyman he refers to the synonym of comma.

The varieties are distinguished about as follows:

Hind wings below dark brown, spots moderate

Hind wings below green, spots often reduced

laurentina colorado

Hind wings below grayish green, the spots often small and tending to

form a stralght row; smaller than the other forms columbia

Hind wings below light yellow or greenish

idaho

Distribution-This is a European species, found in Northern United States, the Pacific States, and in the Rocky Mountain States. Dr. Coues collected the variety colorado along the northern border in 1874 . It has been taken by Barnes at Aldridge, and by Brandegee at Helena. 


\section{THE PAWNEE SKIPPER, Erynnis pawnee, Dodge.}

Male expanse, 1.45 inches, $36 \mathrm{~mm}$. Primaries above fulvous. Subcostal, submedian and subdorsal veins black at the base. Stigma black and conspicuous, followed by a dusky shade. A small black line at the extremity of the disk is preceded by a yellowish white or semi-transparent spot in the disk; a similar spot, triangular in shape, appears between the first and second median veiniets at their divarcation, and two others between the sixth and seventh subcostal veinlets. The outer margin is broadly bordered with brown, which is finely powdered with fulvous scales toward the apex.

Two nearly square fulvous spots between the last subcostal and first median veinlets, separate an oval brown patch that lies at the extremity of the disk, from the border. Costal edge blackish. Fringe white, dusky toward the apex.

Secondaries fulvous, bordered with brown; broadly and darkest along the anterior edge, narrowly on the outer edge, where it appears as cuneiform spots between the veinlets, and broadly along the innner edge, where it is sprinkled with fulvous. Most of the veins on both wings are black. Underside of both wlngs yellow. Primaries black at base, having a black line corresponding to the stigma.

Inner margin brown, preceded by a large whitish patch. Five pale whitish spots near the apex, another in the disk, and one between the first and second median veinlets. Fringe white at the anal angle, brown tipped with white at the apex. Secondaries have a whitish spot in the disk, and are crossed by a nearly straight row of small whitish spots. Head and thorax greenish yellow. Body black. - Abdomen, breast and palpi yellowish white. Antennae black and yellow above, white tipped with chestnut below. The spots on the under side of secondaries sometimes obsolete.

Female, light brown above, with a slight purplish reflection. Primaries sprinkled with fulvous scales near the base and inner edge. There is a large, square, white spot in the disk, and an unequal, curved row of nine white spots extend from the costa-beginning about two-tenths of an inch from the apex-to the submedian vein. The first three spots are narrow and equal, the fourth and fifth are small and square and lie nearest the outer edge of the wing, the sixth is large and triangular, the seventh largest and square, the eighth and ninth are irregular in shape and partly fulvous.

Secondaries darkest along the anterior margin. A curved row of five whitish yellow spots, of which the second and third are longest, crosses the wing beyond the disk, and in the disk is a small yellow spot. A yellow streak precedes the last median veinlet, run to the outer margin. Fringe of all the kings white. Below, on the primaries, the same white spots appear as above, except that th eeighth and ninth are merged in a large whitish patch situated as in the male. A brown patch covers part of the base and inner margin, and extends to the center of the wing. On the secondaries three small white spots appear near the apex. The ground color of both wings is yellowish white, most deeply tinged with fulvous near the costal border of the primaries. Fringes white. Head, 
thorax and body brown above. Abdomen and palpi white. Antennae black above, whitish tipped with red below. This species was taken at Glencoe, Nebraska, upon high rolling prairie, from the first to the middle of September.

The above is the original description, copfed from Canadian Entomologist, Vol. VI, No. 3.

Distribution-The Western plains, Utah and Nebraska, according to Dyar. Given in "List of Butterflies taken by H. K. Morrison in Dakota and Montana, 1881," in Canadian Entomologist, Vol. XIV, 1882. We cannot tell from this list whetber it was taken on the plains of Dakota or Montana.

THE WOODLAND SKIPPER, Thymeıcus sylvanoides, Boisduval.

Butterfly-Expanse, 1.25 to 1.34 inches, 31 to $34 \mathrm{~mm}$.

Male, upper side fulvous, darker at outer edge; a black stigma, large; several (three) light spots near outer angle, beyond stigma. Female, upper side with less fulvous, the wings prevalently fuscus, and the red color reduced to a spot at the end of the cell; a median band of fulvous spots on both wings. On the under side in both sexes the wings are quite pale gray, with the costa near the base and the cell of the primaries reddish. The primaries at the base near the inner margin are blac. The spots on the under side reappear, but are pale and faint. This is to be expected in the state, but we have not seen the species among the collections.

Early Stages-Unknown.

Distribution-The species ranges along the Pacific coast from British Columbia to California, and eastward to Colorado.

\section{Genus OCHLODES, Scudder.}

THE INDIAN SKIPPER, Ochlodes sassacus Harris. Fig. 115.

Butterfly-Expanse, 1.2 to 1.4 inches, 30 to $35 \mathrm{~mm}$.

Male-Upper surface fulvous, dark brown or balck through the discal cell and along the border, the base dusky. A black, oblique stigma or sex-mark below the cell.

Under side pale fulvous, the posterior part fuscus; the five subterminal spots of the upper surface repeated, a spot at the end of the cell, a large triangular patch, with dentate outline, all yellowish white. The hind wings have a sub-terminal band of six whitish spots across the anterior two-third of the wing, and a spot at the end of the cell.

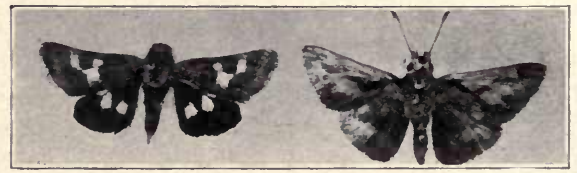

Fig. 115. Ochloedes sassacus, female on left, male on right. 


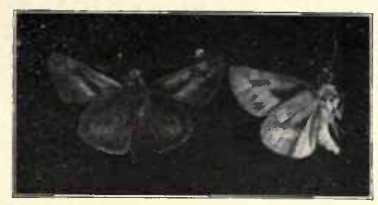

Fig. 116. Ochloedes sassacus, upper and lower surfaces of male.

Female-This is larger, the fulvous ground color paler, the outer marginal shades darker, and the discal stigma is replaced by a dark brown shade. The fore wings have a row of eight yellow spots, and two elongate spots, more or less distinct, in the outer part of the cell.

On the under side the spots of the fore wings are repeated, pale, the lower of the outer row broadly expanded.

Body brown above, with grayish hairs, lighter beneath.

Early Stages-The caterpillar feeds on grasses.

Distribution-From New England to Florida, westward to Colorado and Montana. In Montana collected by Elrod at Missoula (9), at McDonald Lake in the Mission Mountains (3), and in numbers of the University of Montana iological Station. Douglas and Smith collected it at Wiles Hot Springs (14).

\section{Genus LIMOCHROES, Scudder.}

The antennae are about half as long as the costa; the club is robust, elongate, with a very short terminal crook; the palpi have the third joint erect, short, bluntly conical. The male has a linear discal stigma on the upper side of the fore wing. The egg is hemispherical, somewhat flattened on the top. The larvae feed on grasses, and construct a tube-like nest of delicate films of silk between the blades.

THE CROSS-LINE SKIPPER, Limochroes manataaqua, Scudder.

Butterfly-Expanse, 1.00 to 1.20 inches, 25 to $33 \mathrm{~mm}$.

In the male the wings are dark brown marked and tinged with yellow; the brand is very slender and nearly straight; outside of it there is a patch of brown scales, which makes it appear wider than it is; between the brand and the costal margin the wing is heavily covered with yellow scales, and the transverse row of spots beyond the middle of the wing is more or less distinct; the hind wings are tinged with yellow, sometimess the transverse row of spots is faintly indicated.

In the female the wings are dark brown above with a transverse row of whitish spots beyond the middle of the fore wing; hind wings without spots.

Distribution-The species is reported to have a general distribution over the Uniced States. It has been collected by Cooley at Bozeman. 


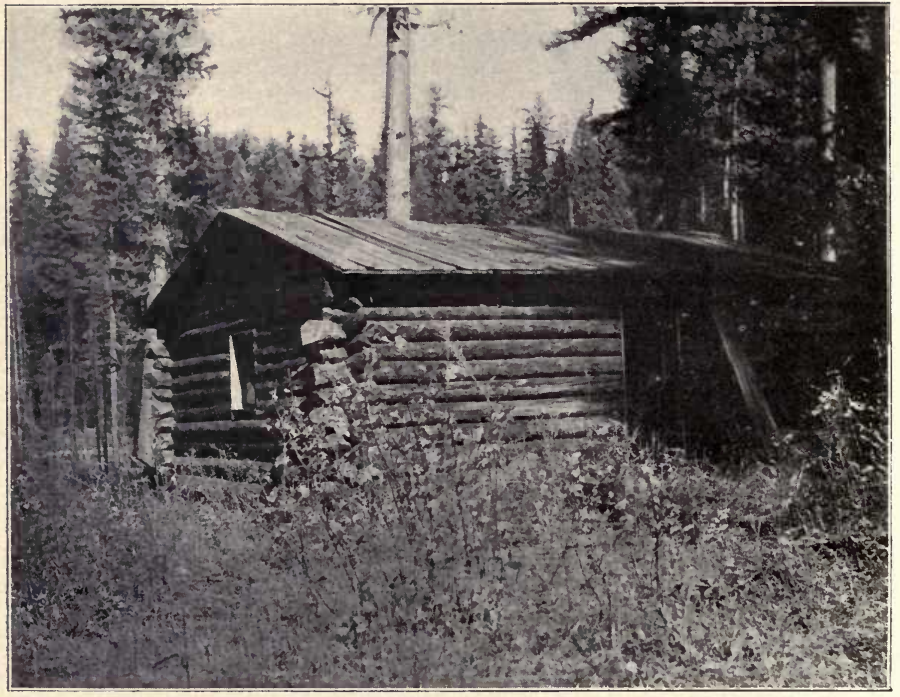

Fig. 117. Old cabin at Swan Lake, where Vanessa j. album, the Compton tortoise shell butterfly, was taken in great numbers. 
List of Species of Butterflies Collected by Campbell Carrington and

William B. Logan, of the Expedition, in 1871.

вy W. H. Edwards.

Papilio rutulus, Boisduval.-Junction.

turnus, Linn.-Montana.

Parnassius smintheus, Doubleday.-Junction; Yellowstone. clodius, Menetus.-Montana.

Pieris protodice, Bois. (Printed Pinis protodin.)-Several localities.

Anthocaris ausanoides, Bois.-Hot Springs.

Colias eurytheme (printed enegthenu), Bois.-Hot Springs.

philodice (printed philodin), Godart.-Hot Springs.

alexandra, Edwards.-Yellowstone.

astraea, Edwards.-Colorado.

Argynnis edwardsii, Reakirt.-Junction.

montivaga, Behr.-Junction.

meadii, Edwards.-Cclorado.

myrina, Cramer.-Colorado.

Melieta (spelled Meletaea) hofmanii, Beahr.-Junction.

Phyciodes tharos, Boisd.

Grapta satyrus, Edwards.-Hot Springs.

Pyrameis huntera Drury.-Montana.

Vanessa antiopa, Linn.-Montana.

milberti (spelled melbertii), Godart.-Bozeman City.

Coenonympha ochraces, Edwards.-Virgini ${ }_{\text {w City. }}$

Erebia rhodia, Edwards.-Yellowstone.

haydenii, Edwards, new species.-Yellowstone.

Satyrus nephele, Kirby.-Yellowstone.

silvestris, Edwards.-Virginia City.

sthenele, Bois.-Virginia City.

Chrysophanus rubidus, Edwards.-Stinking Creek, (Mont).

Lycaena anna, Edwards.-Pleasant Valley.

acmon, Bois.-Meadow River. (Mont.)

Pyrgus syrichtus, Fab.-Montana.

Herpena comma, Linn.-Virginia City.

In addition to the above were several specimens, especially of Lycaenidae, that were too much injured for recognition.

W. H. EDWARDS,

January, 1872.

Coalburgh, West Virginia.

EREBIA HAYDENII, Edwards, New species.

Male: expanse, 1.6 inches.

Upper side fuscous, immaculate; under side a shade paler, much irrogated with gray scales; primaries immaculate; secondaries have a complete series of black ocelli along the edge of hind margin, one on 
each interspace; each ocellus narrowly ringed with ochraceous, and having minute white pupil.

The above is copied from "Preliminary Report of the United States Geological Survey of Montana and Portions of Adjacent Territories: Being a Fifth Annual Report of Progress. By F. V. Hayden." This is the report for 18,1 , printed in 1872 . 


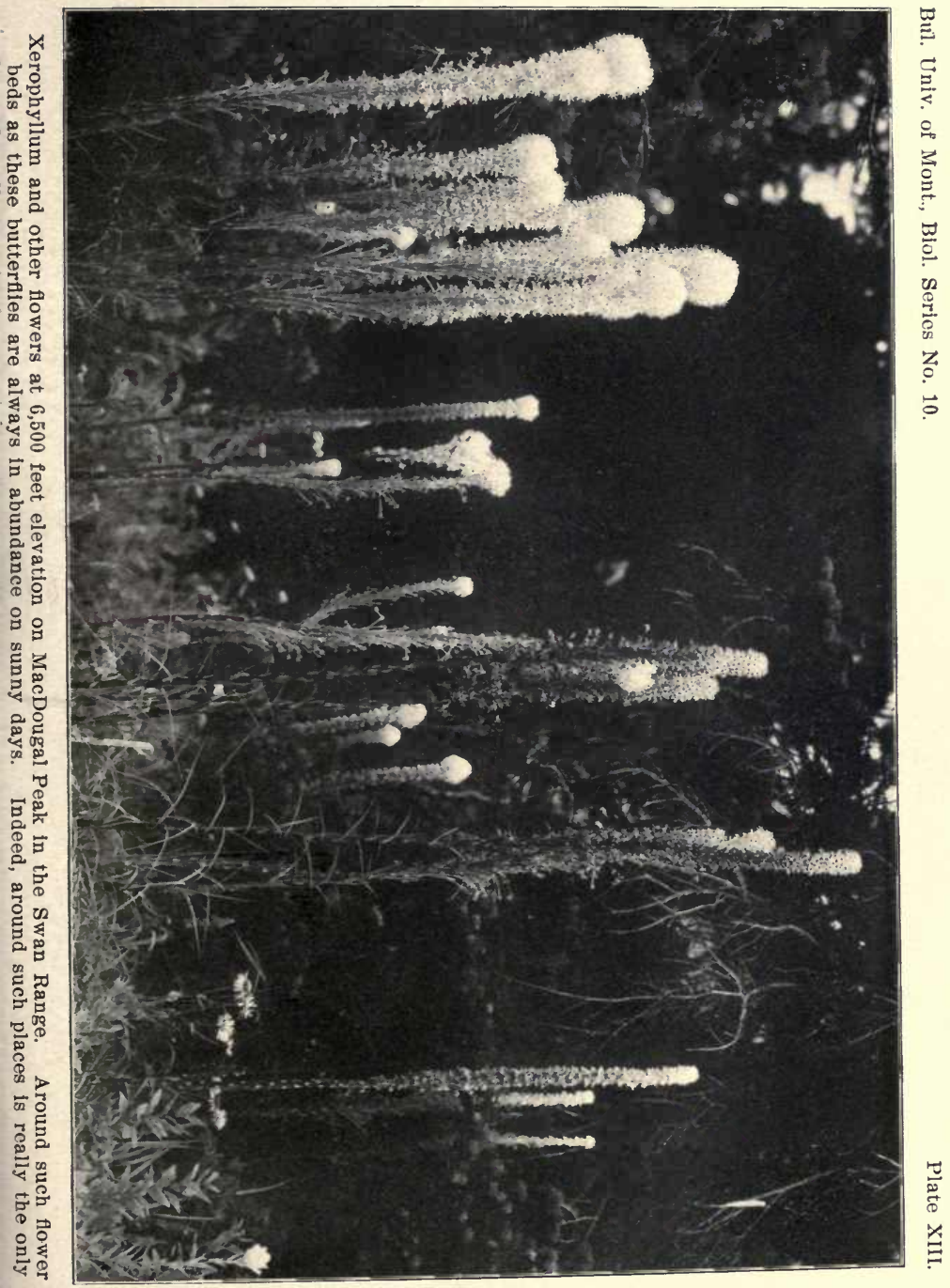





\section{Literature Used in Connection With This Study.}

Barber, H. G., a List of Nebraska Butterflies. Proc. Nebr. Acad. Sci., Vol. IV, pp. 16-22, 1894.

Behr, H. Proceedings, Calif. Acad. Sci., Vol. 3, 1863-68, description of Lemonias (Melitea) cooperi.

Comstock, John Henry and Anna Botsford. How to Know the Butterflies. 1904. Appleton's.

Dodge, G. M. Hesperia pawnee, Canadian Entomologist, Vol. VI, No. 3, 1874.

Dyar, Harrison G., A Review of the Hesperidae of the United States. Journal N. Y. Ent. Soc., 1905, Vol. XIII, No. 3, pp. 111-142.

Dyar, Harrison G. A List of North American Lepidoptera and Key to the Literature of this Order of Insects. Bul. U. S. Nat. Mus. No. 52. 1902.

Dyar, Harrison G. The Lepidoptera of the Kootenai District of British Columbia. Proc. U. S. Nat. Mus. Vol. XXVII, pp. 779-938, 1904.

Dyar, Harrison G. Lepidoptera of the Harriman Alaskan Expedition, Alaska, Vol. III. Doubleday, Page \& Co., 1904.

Edwards, William H. The Butterflies of North America, three olumes, quarto, with nearly one hundred and fifty colored plates. Houghton, Mifflin \& Co. Last volume issued in 1897.

Edwards, W. H. List of Species of Butterfles Collected by Campbell Carrington and William Logan, of the Expedition, in 1871. "Preliminary Report of the United States Geological Survey of Montana and Portion of Adjacent Territories. Being a Fifth Annual Repor of Progress. By F. V. Hayden," 1871, printed in 1872.

Edwards, W. H. Description of two New Species of North American Butterflies, Canadian Entomologist, Vol. XIV, 1882, pp. 2-6.

Edwards, W. H. On the Lepidoptera collected by Dr. Elliott Coues, U. S. A., in Montana, during 1874.

Edwards, W. H. Notes on Dr. A. Speyer's paper relative to Hesperiidae. Can. Ent. Vol. XV, No. 8, pp. 147-151, 1883.

Edwards, W. H. Descriptions of two new species of Meliteas belonging to North America. Canadian Entomologist, Vol. XX, pp. 81-84, 1888.

Edwards, W. H. Notes on Danais Archippus. Canadian Entomologist, Vol. XX, pp. 84-86, 1888.

Elrod, Morton J. A Biological Reconnoiscance in the Vicinity of Flathead Lake. Bul. Univ. of Mont., Biol. Series No. 3, pp. 89-182, pl. XVII-XLVI.

Elwes, Henry J. A Revision of the Genus Argynnis, Trans. Ent. Soc. Lond., 189, Part IV, pp. 535-575. 
Elwes, Henry J. Notes on the Genus Erebia. Trans. Ent. Soc. Lond., 1889, Part II, pp. 317-342.

Elwes, Henry John. A Revision of the Genus Erebia. Trans. Ent. Soc. Lond., 1898, Part II, pp. 169-207.

Field W. L. W. Problems in the Genus Basilarchia. Psyche, Vol. XI, Numper 1, pp. 1-6, three plates.

Fiske, William F. An Annotated Catalogue of the Butterflies of New Hampshire. N. H. Col. Ag. Ex. Sta., Technical Bulletin No. 1, 1901. French, G. H. Butterflies of the Eastern United States, 1896, Lippincott. Harris, W. H. Insects Injurious to Vegetation., 1862

Holland, J. G. The Butterfly Book, 1898.

Mead, Theodore L. Description of two new California Butterflies, Canadian Entomologist, Vol. X, pp. 196-199, 1878.

Scudder, Samuel H. Historical Sketch of the Generic Names Proposed for Butterflies; a Contribution to Systematic Nomenclature. Proceedings of the Aemircan Academy of Arts and Sciences, Boston, 1875, N. S. Vol. II, pp. 91-294.

Scudder, Samuel H. Bulletin of the Buffalo Society of Natural History, Volume 11, 1875, pp.

Scudder, Samuel H. Butterflies of the Eastern United States.

Scudder, Samuel H. The species of the Lepidopterous Genus Pamphlla. Mem. Bost. Soc. Nat. Hist., Vol. II, Part III, Number IV, pp. 341-354, 2 plates, 1874.

Skinner, Henry. A Synonymic Catalogue of the North Ameican Rhopalocera. Philadelphia Academy of Natural Sciences, 1898.

Skinner, Henry. Revision of the American Species of the Genus Coencnympha. Transactions American Entomological Society, Vol. XXVI, 1900, pp. 299-310, one colored plate.

Speyer, Dr. A. Remarks on the Hesperiidae sent to me by Mr. W. H. Edwards. Can. Ent Vol. XV, No. 8, pp. 141-147, 1883.

Strecker, Hermann. Butterflies and moths of North America, with colored plate. Reading, Pa., 1878.

Snyder, Arthur J. The Argynnids of North America. Reprinted from Occasional Memoirs of the Chicago Entomological Society, Vol. I, No. $1,1900$.

Wiley C. A. Butterfiles at Miles City, Montana. Entomological News,

- Feb. 1894, pp. 36-37. 


\section{Glossary.}

Abbreviated, as applied in Biology, shorter than the ordinary type.

Abdomen, the posterior part of the body.

Aborted, imperfectly developed; redimentary.

Aciculate, needle-shaped, more slender than subulate.

Acuminate, terminating in a long tapering point.

Albino, an animal or plant exhibiting an abnormal deficiency of coloring matter.

Alpine, as applied in Biology, inhabiting a mountain region above the limits of forest growth.

Anal, pertaining to the posterior part of the body.

Anal angle, the inner or posterior angle of the hind wings, next to the body.

Angulate, having angles.

Annulate, furnished with colored rings.

Antennae, two articulated organs of sensation, situated on the head.

Anterior margin, the front margin if the wing; the costa.

Apex, that part of the wing which is farther from the body; the angle between the costa and the outer margin.

Ashen or ashy, ash-colored.

Aureus, golden yellow.

Basal, relating to the base.

Base, as applied to a wing, that part which is joined to the body.

Bifid, cleft.

Bipupillate, applied to an ocellate spot having two pupils or dots within it of a different color from the rest of the spot.

Body, the three parts of an insect, head, thorax, abdomen.

Boreal, pertaining to the north.

Bronze, the color of old brass.

Buff, a brownish-yellow color.

Capillary, hair-like; long and slender, like a hair.

Carinate, keeled; having a longitudinal prominence like the keel of a boat.

Caterpillar, the larva.

Cavdate, tailed:-generally applied to the posterior wings of Lepidoptera to indicate tail-like projections.

Cell, usually in Lepidoptera the space between the subcostal and median veins; the discal cell.

Chitine, the hard part on the outside of insects.

Chrysalis, the third stage of the insect, counting the egg one.

Ciliate, fringed.

Clavate, club-shaped.

Coalesce, to grow together or unite.

Collar, scales back of the head, forming more or less of a ring; the neck. 
Concolorous, of the same color, as the body agreeing in color with the wings.

Confluent, running into each other.

Coniferous, cone-bearing.

connivent, conveying or approaching.

Conoidal, tending to a conical form.

Contiguous, touching; placed so near as a touch.

Convergent, approaching each other towards the tip.

Cordate, heart-shaped.

Corrugated, wrinkled.

Costa, the thickened anterior part of the wing from the base to the apex.

Cremaster, the anal hooks of the chrysalis, which fasten into silk to hold the chrysalis in place.

Crenate, scalloped.

Cretaceous, chalky.

Cruciferous, pertaining to the Cruciferae or mustard family of plants.

Cubitus, the second longitudianl vein of the fore wing.

Cuneiform, wedge, shaped.

Cupreous, coppery; the color of copper.

Dentate, toothed.

Diaphanous, semi-transparent, clear.

Dichotomous, forked; dividing by pairs.

Diffuse, spreading.

Dimorphous, two-formed:- applied to a species existing in two forms having different colors or markings.

Discoidal, disk-shaped.

Disk, the surface within the margin,-usually between the end of the cell and the outer margin.

Diurnal, as applied to Lepidoptera, active during the day.

Divergent, tending in different directions.

Dorsal, of the back.

Dorsum, the back or upper surface.

Echinate, set with prickles.

Edematous, dull translucent white.

Edge, the margin.

Egg, the first stage of an insect.

Ellipsoid, pertaining to a solid every plane of which is an ellipse or circle.

Elliptical, in the form an ellipse.

Emarginate, notched.

Entire, the margin smooth, or without teeth.

Entomology, the branch of zoology that treats of insects.

Epysillate,applied to an ocellate spot included in a colored ring, but destitute of a pupil or central dot.

Excision, a cutting off or out.

Eyes, the organs of sight, composed of numerous hexagonal facets.

Fasciated, banded.

Fauna, the animal distribution of an era, or of a stated period.

Fawn-color, light yellowish brown.

Ferruginous, of the color of iron-rust. 
Filiform, thread-shaped.

Foveae, shallow rounded depressions or pits.

Frontal, pertaining or relating to the front.

Fuliginous, sooty; soot-colored.

Fulvous, orange-yellow.

Fuscous, dark brown with slight mixture of gray.

Fusiform, spindle-shaped.

Geminate, situated in pairs.

Gemmate having buds.

Generic, pertaining to a genus.

Genus, an assemblage of species which correspond in particular characters Globular, like a round ban.

Glutinous, slimy, viscid.

Granulated, covered with small grains.

Gregarious, living in society, or many feeding together.

Habital, a sicuation or locality frequented by insects.

Head, the anterior part of the body.

Hibernaculum, a case of web and leaves in which larvae or pupae hibernate, or a cocoon of silk.

Hibernate, to pass through or survive the winter.

Hind margin, that part of the fore wings which is included between the base and the posterior angle.

Hirsute, rough with strong hairs.

Hoary, covered with a fine white silvery substance or pubescence.

Humeral, the vein in the humerus.

Humerus, the anterior base of the wing.

Hyaline, transparent; vitreous.

Hybrid, an animal or plant produced from the mixture of different breeds, species or genera.

Imago, the perfect or adult insect.

Imbricated, tiled; placed one over another, like shingles on the roof of a house.

Immaculate, without spots.

Incanous, hoary.

Inconspicuous, not readily discernible.

Inner margin, that margin of the hind wings which extends from the base to the anal angle; by some authors used to denote the posterior or hind margin of the fore wings.

Inscriptions, markings.

Involute, coiled specially as certain antennae.

Iridescence, a many colored appearance.

Iris, of an ocellate wing spot, is a circle that surrounds the principal spot. Irrorate, sprinkled.

Jolnts or Articulations, the divisions of thebody or segments of the larva; the divisions of the pupa, more particularly the abdomen; the divisions of the antennae.

Labial palpi, articulated filaments, one on each side of the labium.

Labium, the lower tip. 
Labrum, the upper tip.

Lanceolate, lance or spear shaped.

Larva, the second stage of an insect, counting the egg the first.

Lateral, situated on the side.

Laved or washed, covered with scales of a color different from the ground color, but not quite obscur.ng the latter.

Lenticular, lens-shaped.

Lepidoptera, an odler of insects having four wings covered with minute imbricated scales; butterflies and moths.

Lethargic, becoming torpid or inactive.

Linear, narrow and of nearly uniform width.

Lineated, streaked or marked with lines.

Livid, dark gray, verging towards violet.

Longitudinal, the direction of the longest diameter.

Lunate, crescent-shaped; formed like a new moon.

Lunule, a crescent-shaped marking.

Lurid, of a dirty brown color.

Lustrous, shining.

Maculate, or maculated, spotted.

Mandibles, the upper jaws.

Margin, the edge of wing, or along the edge.

Maxillae, the lower jaws, placed between the upper jaws and the lower lip. Median, middle.

Mesial, middle, as a band or stripes across the middle portion of the wing.

Mesothorax, that division of the thorax to which the middle pair of legs $=-$ e attached.

are attached.

Metamorphoses, transformations. are attached.

Moult, or Molt, shedding or casting off the larva sk:n.

Nebulous, clouded.

Nervule, a small nerve or nervure.

Nervures, divisions of the nerves or veins of a wing.

Neuration, or Venation, the arrangement of the veins of the wings.

Niger, black a little tinged with gray.

Obconic. inversely conic.

Obcordate, inversely heart-shaped.

Oblong, the transverse diameter much shorter than the longitudinal.

Obviate, inversely egg-shaped.

Obsolescant, growing obsolete.

Obsolete, indistinct.

Occiput, the hinder part of the head.

Ucelli, eye-like spots on the wings of Lepidoptera; single eyes of insects.

Ochreous, yeliow with a slight tinge of brown.

Olivaceous, olive-green.

Opaque, having no luster, dull.

Orbicular, round.

Order, the subdivision of a class.

Oval, broadly elliptical. 
Ovate, egg-shaped.

Overlaid, heavily sprinkled with scales of a differezt color from the ground color; ciouded; overcast.

Palpi, in butterflies, the three jointed organs bezeath the head between which the tongue is coiled like a watch-spring.

Perianth, as applied in Botany are the floral leaves that inclose the young sporophylls.

Petiole, of a leaf, the stalk-like portion that bears the blade.

Piceous, pitchy; the color of pitch.

Pika, a tailless hare found in the Rocky Mountains.

Pile, very minute, short hairs.

Pileated, crested; cap-shaped.

Pilous, having long, sparse hairs.

Polymorphous, applied to a species existing in several different forms $a_{3}$ to color, markings, or size.

Porrect, straight out.

Posterior angle, the angle formed by the outer margin and the posterior or hind margin of the fore wing.

Posterior margin, that portion of the fore wings which is opposite the costa.

Postmedia vein, a vein lying between the media and cubitus.

Premedia vein, a vein lying between the media and radia.

Primaries, the fore wings of Lepidoptera.

Proboscis, the tongue or sucking organ.

Pronotum, the anterior part of the covering of the thorax, the covering of the thorax.

Prothorax, the first division of the thorax, to which the first pair of legs are attached.

Protuberant, bulging.

Pruinous, hoary; covered with a whitish powder.

Pubescent, coated with fine hair or down.

Punctured, marked with small empressed dots.

Pupa, the third stage of an insect, country the egg the first; the chrysalis.

Pupate, to assume the pupa form.

Pupil, of an ocellus, the central point.

Quadrangular, having four angles.

Quadrate, square, or nearly square.

Radius, a vein of the wing; the subcostal.

Remote, separate; not near together.

Reniform, kidney-shaped.

Reticulate, resembling net-work.

Retractile, capable of being exserted or drawn in at pleasure.

Retuse, ending in an obtuse sinus.

Ribs, ridges on eggs from the base to the apex.

Roseate, of a rose color.

Rosevs, rose color.

Rufous, reddish.

Rugose or Rugous, wrinkled.

Russet, reddish or yellowish brown. 
Sagittate, arrow-shaped.

Sanguineous, of the color of arterial blood.

Scabrous, rough, with projecting points.

Scales, the dust or imbricated pieces covering the wings.

Secondaries, the hind wings of Lepidoptera.

Segment, a ring or division of the body.

Sericeous, silky.

Serrate, saw-toothed.

Sessile, connected with the part to which it is attached without the intervention of a peduncle or stalk.

Seta, a bristle.

Sinuate, indented.

Sinuous, curving, winding or folding.

Sinus, an indention of execution.

Sparse, scattered.

Species, an assemblage of individuals possessed of permanent characteristics of size, color, and ornamentation, by which they may be distinguished from other forms, and which breed true to their type.

Spinous, armed with spines.

Spiracle, breathing-holes on the side of the body; the stigmata.

Sporophylls, as applied to Botany, leaves which produce only spores.

Sprinkled, marked with thinly-scattered scales of another color than the ground color.

Stigmata (singular Stigma), the breathing-holes on the sides of the body; also, sometimes, spots on a wing.

Stigmated, resembling stigmata.

Striae, lines; transverse elevated lines on eggs.

Striate, marked with lines.

Stridulator, a locust, grasshopper, or other insect that makes a musical or shrill sound by rubbing together specially hardened parts of the body.

Subapical, situated below the apex.

Subcosta, the subcostal vein, situated behind and near the costal vein of an insects wing.

Submarginal, applied to a space or line within the margin.

Subocellate, applied to an ocellus without a pupil.

Suffused, blurred with a color other than the usual one.

Sulphureous, bright yellow; the color of sulphur.

Tail, the terminal segment of the abdomen; an appendage at the posterlor part of the hind wings.

Tarsi, the feet.

Tawny, dull yellowish brown.

Terminal, at the extremity

Testaceous, tile or brick color.

Thorax, that part of the body which is back of the head.

Tibia, that part of the leg which is next to the foot.

Tippet, one or two scale-like appendages of the pronotum of Lepidoptera.

Tongue, the sucking-tube of Lepidoptera.

Tosidity, a lethargic state of hibernation.

Translucent, semi-transparent. 
Transverse, crosswise.

Trochanter, an appendage at the base of the thigh.

Trophi, the mouth parts.

Truncate, cut square off.

Tubercle, a small swelling or prominence.

Undulating, vibrating; wavy.

Umbel, as applied to Botany, a flower-cluster in which a number of the same length spring from the same point, thus radiating like the stays of an umbralla.

Variation, a deviation in function or structure from the usual form, but not breeding true to type.

Veins and Venules, the frame work of the wings.

Venation, see neration.

Venter, the lower part of the body.

Ventricose, distended.

Verticillated, arranged in a circle around an axis.

Villi, soft hairs.

Violaceous, violet color.

Vitellinus, yellow with a slight tinge of red.

Vita, a longitudinal colored line.

Washed, see laved. 



\section{INDEX}

Acadia, 30, 31, 128.

Acadican hair-streak, the, 128.

Acastus checker-spot, 75 .

Acmon, 159.

Actinella, 17.

Admiral, red, 99; Wiedemeyers, 104.

Atranius, 150.

Agapetinae, 44, 105.

Aglais, 50, 97; milberti, 67, 97, 159.

Agriades, 136.

Alcestis, 57, 58 .

Aldridge, Mont., 4.

Alexandra, 40, 159.

Allium, 17.

Alope, 106.

Alpines, the, 113.

Andes, collecting butterflies in the, 43 . Amyntula, 189.

Anicia, 73 .

Anoisa, 45; plexippus̀, 45, 67 .

Anosia plexippus, migration of, 47 .

Anthocaris, 32.

Antiopa, 96, 159.

Aphrodite, 54, 57, 58.

Archippus, 103.

Arge, 65.

Artonys, 54, 65.

Ariadue, 39 .

Argynnis, 3, 5, 50, 54.

Argynnis aphrodite, 57, 58; atlantis, 63 ; bremneri, 62 ; cybele, 54 ; cypris, 67 ; edwardsii, $3,59,67,159$; electa, 63 ; eurynome, 17, 64; hesperis, 61; lais, 54; leto, 44, 56; meadii, 159 ; montivaga, 159 ; nevadensis, $3,60,61,67$; rhodope, 62 .

Astragalus, 47.

Atalanta, 99 .

Atlantis, 63.

Arctics, the, 119.

Arctic skipper, 151.

American coppers, 134.

Astraea, 159.

Augustus, 130.

Ausonides, 33, 159.

Banded hair-streak, the, 128 .

Barnes, Geo. E., 4.

Barber, H. G., 101.

Basilarchia, 50, 102; disippus, 67; archippus, 103 ; lorquina, 104 ; wiedemeerii, 67, 104.

Beckeri, 27, 31.

Becker's white, 32 .
Behr, H., 161.

Big Sandy, Mont., 4.

Bischoffi, 65 .

Bluebell, 108.

Blues, the, 124.

Bottle, for killing, 7 .

Brandegee, E. N., 4.

Bremeri, 54, 62.

Brown. J.isle W., 4.

Branthis, 50, 69 .

Brenthis, helena, 17, 69, 71 ; bellona, 69,10 ; myrina, $5,69,70,149$.

Bruce's Swallowtail, 24.

Bruce's checkerspot, 73.

Butterflies"on Chimborazo, 104.

Butterfly Facnies, 140.

Cabbage butterfly, 29 .

Camberwell beauty, the, 96 .

California tortoise shell, 92.

California white, 31 .

Camillus crescent, 82 .

California, 92, 94.

Carlota crescent, 80 .

Castilleia, 17.

Cardui, 100.

Caryae, 101.

Catullus, 68, 148.

Cercyonis, 105; alope, 106 ; charon, 71 ; oetus, 71 ; sthenele, 159.

Callophrys dumetorum, 130 .

Centaurea, 145.

Chalceria cupidus, 135; snowi, 135.

Checkered skipper, 147.

Chacker spots, 72 .

Chief mountain, 98.

Chimborazo, 43, 104.

Chionobas varuna, 71 .

Chrysophanus hypophleus, 71.

Chyxus butterfly, 120 .

Claudia, 51, 67.

Clio, 54, 65.

Clouded checkerspot, 75 .

Colias alticola, 43.

Collecting Butterflies in Montana, 108.

Collecting insects, 7 .

Colorado blue, the, 137.

Coenonympha, 114; haydeni, 116, elko, 115; ochracea, 67, 14, 159; tiphon, 116.

Compton tortoise, 90 .

Cooley, Prof. R. A., 4.

Cooper's checker spot, 76.

Coral hair streak 131. 
Coubeaux, Eugene, 4.

Coppers, the, 124, 134.

Craig, Pras. O. J., 5.

Crossline skipper, 157.

Cupido, 135; lycaea, 135; saepiolus, 136.

Cunninghami, 65.

Cyanide bottle, 7 .

Cyaniris ladon, 138.

Cybele, 54, 57.

Danais archippus, 67.

Dark wood-nymph, 107.

Daunus butterfly, 20,66 .

Desmodium, 51.

Dodge, G. M., 161.

Dumetorum, 130.

Dusky-wing, 149.

Dyar, H. G., 161.

Early hair streak, the, 131.

Edwards, W. H., 2, 119, 161.

Edwardsii, 54, 59, 149.

Edwards' Fritillary, 59.

Edith's copper, 132.

Electa, 54, 63.

Elrod, M. J., 161.

Ellis, 41, 42.

Elko, 115.

Elwes, H. J., 161, 162.

Epargyreus, 143, titysus, 144.

Erynnis, 151, 152; assiniboia, 155; comma, 154; colorado, 155; laurentina, 155; nevada, 155; columbia, 155; pawnee.

Elfins, the, 129.

Eryphon hair streak, 130.

Epidemia, 133; helloides, 133; mariposa, 134

Erora, laeta, 131.

Erebia, 113; epipsodea, 13; rhodia, 159.

Euvanessa, 50, 67, 96, 159 .

Euvanessa antiopa, stridulation in, 97.

Erigeron macranthus, 70 .

Eriphyle, 39.

Erinna, 65.

Eugonia, 50.

Eugonia j-album, 90, 93; californica, 92.

Euchloe, 32, 67.

Euploeinae, 44.

Euptoieta, 50, 51, 67.

Eurymedon Swallowtail, 23.

Eurynome, 54, 64.

Eurymus; alexandra, 5, 37, 38, 40, 159; eurytheme, $37,38,40,67,159$; ariadne, 39 , astraea, 159 ; eriphyle, 38,67 ; elis, 41, 42; keewayden, 38 ; meadii, $17,37,41,42$; ochracea, 17; philodice, $37,38,40,159$; scudderi, 37, 41.

Eurytheme, 38, 40, 67, 159.

Everes amyntula, 139.
Exchanges, 123.

Faun, the, 85.

Faunus, 85.

Field, W. L. W., 162.

Fiske, Wm. F., 162.

French, G. H., 162.

Fritillaries, the, 54 .

Gaeides, 132; editha, 132; xanthoides, 133.

Garita, 152.

Greddes, Capt. Gamble, 59.

Geum, 17.

Giant skippers, 142.

Glossary, 162.

Gossamer winged butterflies, 124.

Great copper, the, 133.

Graceful anglewing, the, 88 .

Gracilis, 88.

Grapta zephyrus, 67.

Great Spangled Fritillary, 54.

Gray Hair-Streak, the, 126.

Green white-spotted hair streak, 130

Greenish blue, 136.

Harris, w. H., 162.

Hayden, F. V., 160.

Hayden's ringlet, 116, 159.

Hadge-row hair-streak, 127.

Helena fritillary, 71.

Heodes ,134; hypophleas, 134.

Heliconinae, 44.

Heliopetes syrichtus, 146.

Hesperis, 59, 61.

Hesperis Fritillary, 61.

Hesperiina,..superfamily, 13, 142.

Hesperiidae, 142.

Hesperia tesselata, 147.

Hesperopsis lena, 147.

Hoary elfin, the, 129.

Hoffmanns checker spot, 75, 159.

Holland, W. J., 123, 162.

Hum ooldt, 104.

Huntera, 101, $15 y$.

Hyde, M. E., 77.

Iaalia, 54.

Incisalia, 129; irus, 129 ; niphon, 129 ; eryphon, 130; augustus, 130.

In dian skipper, 156.

Irus, 129.

j-album, 90, 93.

Keewayden, 39.

Labelling insects, 9 .

Lady butterflies, 98 .

Laidon, 116.

Leanira checker spot, 75 .

Laeta, 131.

Lemonias, 50,72 ; chalcedon, 72 ; anicia, 72,73 ; brucei, 72 , 73; cooperi, 72,76 ; hoffmannii, $72,75,159$; leanira, 72,75 ; nubigena, 72,75 ; taylori,..., 73; whitneyi, 72, 76 .

Leto, $44,54,56,57$. 
Leto butterfly, the, 56 .

Ladon, 138.

Lena skipper, 147.

Libytheinae, 44.

Limochroes, 151, 157; manataaqua, 157.

Liparops, 128.

List of Butterfiles taken by H. R. Morrison, 118.

Lorquina, 104.

Loulsiana tanager, 108.

Lycaea blue, the, 135.

Lycaenidae, 13, 124.

Lgdanus, 136.

McDougal Peak, 18, 93.

Maley, Frances Inez, 4.

Mariposa lily, 108.

Mariposa, 134.

Mead, Theodore L., 162.

Meadow browns, 105 .

Meadii, 41, 42, 140.

Mertensia, 17.

Meadow fritillary, 70.

Meadow crescent, 81.

Melinus butterfiy, the, 126.

Melissa, 124, 137.

Migration of Anosia plexippus, 48.

Milberti, 97, 159.

Milbert's tortoise shell, 97, 159.

Miles City, 3.

Mission Mountains, 18, 93.

Monarch butterfly, 45, 102.

Mount Lo Lo, 3.

Mountain swarming of Vanessa californica, 94.

Monuste, 27.

Montana College of Agricutlure and Mechanic Arts, 4.

Montivaga, 147, 149.

Mountain silver spot, 63.

Mount Shasta, 94.

Mourning cloak, the, 96 .

Musti “d white, 30.

Mylitta crescent, 80 .

Myrina, 69, 149.

Napi, 26, 30.

Neominois ridingaii, 121.

Neophasia, 26, 27; menapia 26, 27.

Nephele, 106, 159.

Net ,how to make, 7 .

Nevadensis. 54, 60 .

Nevada Fritillary, 60.

Nitr3. swallcw tail, 25.

Niphon, 129.

Nomiades, 136; lygdanus, 136.

Nort'lern duskywing, 194.

Niıligena, 7 .

Nymphalidae, 13, 44.

Nymphalinae, 44, 50.

Nyanpsy, the, 50 .
Occidentalis, 27, 29.

Ochracea, 114, 159.

Ochre ringlet, 114.

Oeneas, 119; chryxus, 5, 120; uhleri, 120.

Ochlodes, 150, 156; sassacus, 156.

Oarisma, 150, 151; powesheik, 151; garita, 152.

Olympia, 35 .

Orange margined blue, the, 137.

Orange tip, 33.

Pallida, 30, 31.

Painted Lady, 100.

Papering specimens, 8.

Pamphila, 150; palaemon, 150.

Pamphilinae, 150.

Papilio, 19; bairdii, 24; brucei, 19, 24; daunus, 19, 20, 22; eurymedon, 19, 23 ; nitra, 19, 25; oregonia, 24; turnus, 19, 21, 22, 159; rutulus, 19, 2,159 ; zolicaon, $19,24,25,67$.

Papilionidae, 13.

Papilionina, superfamily, 13.

Papilioninae, sub-family, 19.

Parnassiinae, 13.

Parnassius, 14, 159; clodius, 14, 16, 159 ; smintheus, 14, 15, 17, 18.

Pearl crescent, 79.

Persius, dusky-wing, 149.

Pawnee skipper, 155.

Philodice, 37, 159.

Pholison catullus, 148.

Phyciodes, 5. 50, 78; tharos, 67, 78, 79, 159; mylitta, 78, 80 ; nycteis, carlota, $67,78,80$; pratensis, 78,81 ; camillus, 78,82 .

Pieridae, 13, 26.

Pierinae, 26.

Pike's Peak, 18.

Pinning forceps, 10.

Pins, 10.

Pieris Xanthoides, 43.

Pine white, 26.

Pinchincha, 26.

Pileated woodpecker, 109.

Plexippus, 45.

Polygonia, 50.

Polygonum, 17.

Polygonia, 84, 94; gracilis, 84, 87; faunus, 85 ; hylas, 85 ; silenus, 85 ; pratensis, 81 ; zephyeus, $67,85,87$.

Pontia, 26, 27; beckeri, 27, 32; monuste, 27 ; napi, 27,30 ; occidentalis, 27,29 ; protodice, $27,28,67,159$; rapae, $27,29,65$; sisymbri, 27,31 .

Potassium cyanide, 7 .

Potentilla, 17.

Portulaca, 51.

Portulaca, 51.

Poweshiek skipper, 151. 
Pratensis, 81.

Protodice butterfly, 28 .

Purplish copper, the, 133.

Pylades, 144.

Pyrameis cardui, 67.

Pyrgus, monticaga, 147; syrictus, 159.

Rapae, 27, 29.

Reakirt's copper, 134.

Red admiral, 99.

Regal fritillary 4.

Rhodia, 159.

Rhodope, 54, 62 .

Rhamnus, 23.

Ricker, Edith, 4.

Ricker, Maurice, 49.

Riding's satye, 121.

Ringlets, the, 114 .

Ringless ringlet, the, 115.

Rubidus, 135, 159.

Ruddy copper, the, 135.

Rustiea,-136.

Rusticus, 136; melissa, 124, 137; glaucon, 137; shasta, 138.

Ruffed grouse, 109.

Rútulus swallow-tail, 66 .

Sara, 34.

Satyr, the, 86; Ridings', 121.

Satyrus, 159 ; olympus, 5 .

Sassacus, 156.

Saepium, 127.

Scelothrix, 1.5; centaurea, 145 ; scriptura, 146.

Scudder, S. H., 162.

Scudder's sulphur, 41.

Scudderi, 41.

Sedum, 17, 51.

Semnopsyche, 50.

Setting board, 10.

Scriptura, 146.

Shasta blue, the, 138.

Shasta, Mt., 94.

Silene, 17.

Silver spots, 54.

Silver-bordered fritillary, 69 .

Silvery blue, 136.

Sisymbri, 27, 31 .

Skippers, the, 142 .

Silver spotted skipper, 144.

Skinner, Henry, 162.

Snyder, A. J., 162.

Small checkered skipper, 146.

Sooty-wing, the, 148.

Speyer, Dr. A., 162.

Southern white, 28.

Snow's copper, 135.

Spring azure, 138.

Strymon titus, 131.

spaulding, T. C., 4.

Speyeria, 52, 67 .
Sthenele, 159.

Spreading insects, 9.

Striduation in Euvanessa antiopa, 97.

Strecker, Hermann, 162.

Streckers sulphur, 41.

Sulphur, the common, 37.

Sulphur, alexandus, 40.

Sulphurs, the, 26, 37.

Swan Range, 4, 18, 93.

Swan Lake, 93 .

Sylvestris, 105, 159.

Synchloe, 26, 32; sara, 32; ansonides, 33 ; sara, 34 ; olympia, 35 .

Syrichtus, 146, 159.

Swinton, A. H., 97.

Taylor's cuecker-spot, 73.

Thanaos, 149 ; persius, 149 ; afranius, 150.

Tnymelicus, 151.

Tessellata, 71, 147.

Tharos: 79, 159 .

Thermopsis, 41.

Thistle butterfly, 160 .

Tiphon, 116.

Tityrus, $68,144$.

Tortoise shell, Milbert's, 97.

Thecla ,127; acadica, 128; calanus, 128; saepium, 127; liparops, 128.

Turnus, 66, 21 .

Turnus swallowtail 21, 66 .

Unıversity of Montana Biological Station, 2,15 .

Uhleri, $1 \% 0$.

Uncas, 153.

Uranotes mlinus, 126.

Uranotes melinus, 126.

Vanessa, 50, 98, 99; atalanta, 99 ; californica, $5,67,94$; cardui, 100 ; caryae, 101; huntera, 101, 159; j-album, 5.

Variegated Fritillary, 51.

Varuna, 120.

Venation of $\mathrm{t} \_$e wings, 10.

Viceroy, the, 103.

Ward, Albertine, 141.

West Coast Lady, 101.

Western white, 29.

w estern tailed blue, 139 .

Whitney's checker spot, 76 .

Whites, the, 26, 27.

Whymper in the Andes, 43.

Wiley, C. A., 34, 112.

Wiedemeyer's admiral.

Wiedemeyeri ,104.

Wiley, C. A., 162.

Wood-nymphs, 105.

Woody, Mt., 6 .

Zephyr, the, 87.

Zephyrus, 87.

Zc_icaon butterfly, 35, 66 . 


\section{ERRATA.}

Page 3, seventh line from the bottom, read edwarosii for edwardsi.

Page 5, sixth line from bottom, read Lycaena for lycana.

Page 14, for Fig. 13, read Fig. 14.

Page 15, for Fig. 14, read Fig. 13.

Page 66, eleventh line from the bottom, read zolicaon for zolicoan.

Page 97, thỉrd line from top, for Branedgee read Brandegze.

Page 111, seventh line from bottom, for Spiraca read Spiraea.

Page 112, tenth line from bottom, for Lycaona read Lycaena.

Page 112, twenty-third line from bottom for Basilachia read Basilarchia.

Page 112, fifth line from bottom, for sminthcus read smintheus.

Page 140, first line of fourth stanza, for whitness read whiteness.

Page 143. In the key, after Hesperopsis read P. 147; after Scelothrix read

P. 145; after Heliopetes read P. 147; after Pyrgus read P. 147; after

Pholisora read P. 148; after Thanaos read P. 149.

Page 151. In the key, after Ochlodes read P. 156; after Thymelicus read

P. 156; after Erynnis read P. 152; after Limochroes read P. 157.

Page 156. After THE WOODLAND SKIPPER read Thymelicus.

Page 159. Seventh generic name from top, read Melitaea for Melieta. 
UC SOUTHERN REGIONAL LIBRARY FACILITY

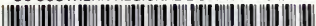

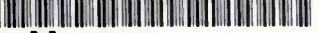
AA 0012946919

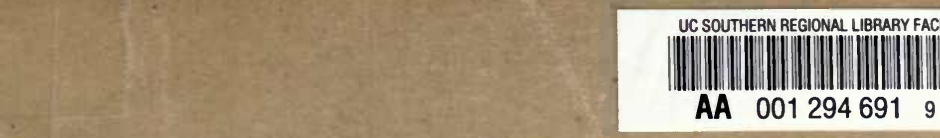
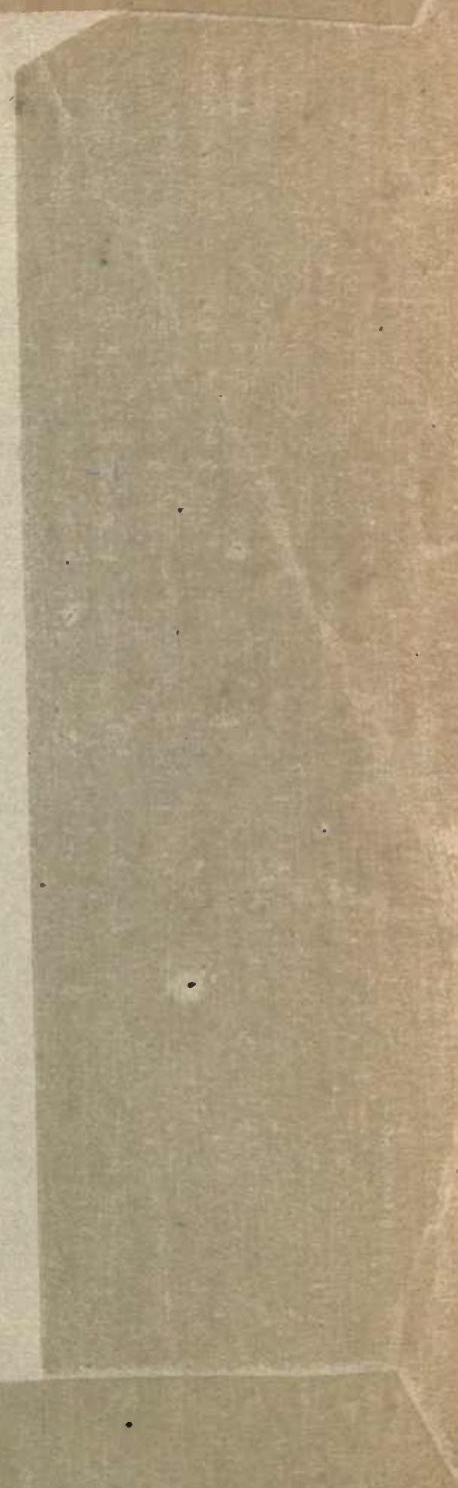


\section{Volume 1. Bulletins of the University of Montana, Biological Series.}

No. 1. Summer Birds of Flathead Lake, by P. M. Silloway. 84 pp., Plates I-XVI.

No. 2. Announcement of the Fourth Annual Session of the University of Montana Biological Station. $4 \mathrm{pp}$.

No.3. A Biological Reconnaissance in the Vicinity of Flathead Lake, by Morton J. Elrod. Pp. 89-182, plates XVIII-XLVI, figs. 1-3.

No. 4. Announcement of the Fifth Annual Session of the University of Montana Biological Station. Pp. 183-190, 4 ills.

No. 5. Lectures Delivered at the University of Montana Biological Station during the Session of 1902. Pp. 191-288, plates XLVII-LII, figs. $4-31$.

No. 6. Additional Notes to Summer Birds of Flathead Lake, by Perley Milton Silloway, with Introduction by Morton J. Elrod. Pp. 289308 , plates LIII-LVII.

No. 7. Lichens and Mosses of Montana, a list, by Wilson P. Harris and Carolyn W. Tarris. Pp. 309-331. Plates LVIII-LXIV.

No. 8. Announcement of the Sixth Annual Session of the University of Montana Bjological Station. Pp. 332-343.

No. 9. Announcement of the Seventh Annual Session of the University of Montana Biological Station. Pp. 343-355.

\section{Volume II.}

No. 10. The Butterflies of Montana, by Morton J. Elrod, M.A., Ph.D., assisted by Frances Inez Maley, B.A. Pp. 1-174, one colored and thirteen black and white plates, and twenty-five figures. 